\title{
Mineralogical, Petrophysical and Economical Characterization of the Dimensional Stones of Uruguay; Implications for Deposit Exploration
}

\author{
Dissertation \\ zur Erlangung des Doktorgrades \\ der Mathematisch-Naturwissenschaftlichen Fakultäten \\ der Georg-August-Universität Göttingen
}

vorgelegt von

Manuela Morales Demarco

aus

Rivera, Uruguay 
Referent: Prof. Dr. Siegfried Siegesmund

Korreferent: Prof. Dr. Pedro Oyhantçabal

Tag der mündlichen Prüfung: 05.06.2012 


\begin{abstract}
Dimensional stones are known since the ancient world as noble mineral resources and have been used for the construction of magnificent pieces of art and architecture that were built to endure. Some examples are the Pyramids in Egypt or the Aphrodite of Milo in Greece. They maintain until today their position as a preferred building material because of their strength, varied color and décor and stability against environmental factors
\end{abstract}

In Uruguay diverse varieties of dimensional stone are mined, commercialized and applied. High quality dolerites (commercially known as black granite) represent the most relevant variety, and therefore, were intensively studied in this research. The most important varieties of gray and colored commercial granites (lithologically granitoids and syenitoids) were also included in this research. The dolomitic slates have been also studied, since they represent a traditional natural stone in Uruguay.

The main uses of the different types of dimensional stone of Uruguay are as façade cladding, countertops and outdoor and indoor floor slabs. Dolerites can also be used for special applications due to their excellent petrophysical properties, as for example precision tables and load-transferring masts.

The lack of sufficient scientific studies in these important mineral resources led to the development of the present research. The main focus was in the petrographic, petrophysic and deposit characterization, and in the analysis of the economic aspects related to the dimensional stones of Uruguay. 


\section{Kurzfassung}

Natursteine werden seit dem Altertum als wertvolle mineralische Ressource geschätzt und dienten seitdem zur Errichtung der herausragendsten architektonischen wie künstlerischen Werke, die lange Zeiträume, teilweise Jahrtausende, überdauert haben. Bekannte Beispiele hierfür sind die Pyramiden Ägyptens und die Aphrodite von Milo in Griechenland. Die Wertschätzung als hervorragendes Baumaterial hat auch heute noch Gültigkeit dank ihrer Festigkeit, ihres Farbspektrums und Dekors, sowie ihrer Verwitterungsresistenz.

In Uruguay werden vielfältige Typen von Natursteinen gefördert, vermarktet und verwendet. Dolerite von höchster Qualität (kommerziell als schwarze Granite bezeichnet) sind die bedeutendsten und werden deshalb in dieser Studie eingehend untersucht. Ebenso werden die wichtigsten Varietäten von grauen und farbigen Graniten (lithologisch: Granitoide und Synenitoide) hier betrachtet. Auch die dolomitischen Schiefer wurden in die Studie einbezogen, da es sich bei innen um einen traditionellen Werkstein aus Uruguay handelt.

Die häufigste Verwendung finden Natursteine aus Uruguay als Fassadenverkleidung, Arbeitsplatten und Bodenfliesen im Außen- wie Innenbereich. Die Dolerite können aufgrund ihrer exzellenten petrophysikalischen Eigenschaften auch für spezielle Sonderverwendungen wie Präzisionstische oder lastabtragende Bauteile benutzt werden. Die vorliegende Forschungsarbeit soll helfen die bestehende Lücke an wissenschaftlichen Untersuchungen für diese wichtige mineralische Ressource zu schließen. Das Hauptaugenmerk richtet sich auf die petrographische, petrologische und lagerstättenkundliche Charakterisierung, ferner auf die ökonomischen Aspekte des Natursteinpotentials von Uruguay. 


\section{CONTENTS}

1. General introduction 1

2. Dolerites 5

$\begin{array}{ll}\text { Abstract } & 5\end{array}$

2.1. Introduction 5

2.2. Geological setting of the dolerite dike swarm in Uruguay 11

2.3. Characterization of the dolerite deposits 14

$\begin{array}{ll}\text { 2.3.1. Geochemistry } & 18\end{array}$

$\begin{array}{ll}\text { 2.3.2. Petrography } & 22\end{array}$

2.3.3. Determination of commercial varieties: influence of grain size, fabric, chemical and mineral composition $\quad 30$

$\begin{array}{ll}\text { 2.3.4. Color measurements } & 31\end{array}$

2.4. Occurrences and deposits 33

2.4.1. Regional distribution: length, width, frequency, country rock $\begin{array}{ll}\text { relations } & 33\end{array}$

2.4.2. Characterization of dolerite deposits: controlling parameters $\quad 35$

2.4.3. Quality assessment of dolerite deposits 38

2.4.4. Characterization of the waste material 39

2.5. Petrophysical properties $\quad 41$

2.5.1. Density, porosity and thermal expansion 41

2.5.2. Mechanical properties of black dimensional stones 42

2.6. Summary: evaluation of the "black stone" deposits 44

2.6.1. Quality assessment with respect to color and décor 44

$\begin{array}{ll}\text { 2.6.2. Petrophysical aspects } & 47\end{array}$

$\begin{array}{ll}\text { 2.6.3. Block size distribution and modeling } & 47\end{array}$ 
Abstract

3.1. Introduction

3.2. Geological setting

3.3. Regionalization of commercial granite deposits

3.4. Lithological inventory

3.4.1. Mafic rocks

66

$\begin{array}{ll}\text { 3.4.2. Granitoids } & 69\end{array}$

$\begin{array}{ll}\text { 3.4.3. Syenitoids } & 73\end{array}$

$\begin{array}{ll}\text { 3.5. Technical aspects } & 73\end{array}$

$\begin{array}{ll}\text { 3.5.1. Color and décor } & 73\end{array}$

$\begin{array}{ll}\text { 3.5.2. Petrophysical and petromechanical properties } & 77\end{array}$

$\begin{array}{ll}\text { 3.5.2.1. Density and porosity } & 77\end{array}$

$\begin{array}{ll}\text { 3.5.2.2. Water vapor diffusion } & 81\end{array}$

$\begin{array}{ll}\text { 3.5.2.3. Ultrasonic wave velocities } & 81\end{array}$

3.5.2.4. Thermal expansion 82

3.5.2.5. Petromechanical properties 84

3.5.2.5.1. Uniaxial compressive strength (UCS) 84

3.5.2.5.2. Young's modulus $\quad 84$

3.5.2.5.3. Indirect tensile strength 84

$\begin{array}{lll}\text { 3.5.2.5.4. } & \text { Flexural strength } & 85\end{array}$

3.5.2.5.5. Breaking load at dowel hole 85

3.5.2.5.6. Abrasion strength 86

$\begin{array}{ll}\text { 3.6. Deposit characterization } & 87\end{array}$ 
3.6.2. Reserves and economic aspects 98

3.6.2.1. Granitoids 99

$\begin{array}{ll}\text { 3.6.2.2. Syenitoids } & 105\end{array}$

$\begin{array}{ll}\text { 3.7. Conclusions } & 108\end{array}$

4. Slates 116

$\begin{array}{ll}\text { Abstract } & 116\end{array}$

4.1. Introduction 117

4.2. Geological setting of Uruguayan slates $\quad 121$

$\begin{array}{ll}\text { 4.3. Lithological inventory } & 124\end{array}$

4.3.1. Geochemistry 124

$\begin{array}{lr}\text { 4.3.2. Organic carbon } & 126\end{array}$

$\begin{array}{lr}\text { 4.3.3. Petrography } & 127\end{array}$

$\begin{array}{ll}\text { 4.3.3.1. Dolomitic slates } & 130\end{array}$

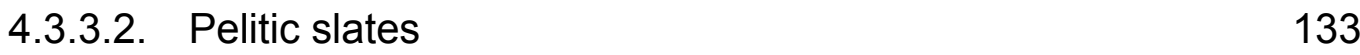

$\begin{array}{lll}\text { 4.3.3.3. Semipelitic slates } & 136\end{array}$

$\begin{array}{ll}\text { 4.3.3.4. Opaque minerals } & 137\end{array}$

$\begin{array}{ll}\text { 4.3.3.5. Rock fabric } & 138\end{array}$

4.3.3.6. Mica layers and mass value 140

4.4. Physical and mechanical rock properties 142

4.4.1. Bulk density, matrix density, porosity 143

$\begin{array}{lr}\text { 4.4.2. Mechanical properties } & 147\end{array}$

$\begin{array}{ll}\text { 4.4.2.1. Flexural strength } & 147\end{array}$

$\begin{array}{ll}\text { 4.4.2.2. Uniaxial compressive strength } & 151\end{array}$

4.4.2.3. Tensile strength 152 
4.4.2.4. Abrasion strength 153

4.4.3. Thermal and hydric expansion and freeze-thaw tests 154

4.4.3.1. Thermal expansion 154

$\begin{array}{ll}\text { 4.4.3.2. Hydric expansion } & 157\end{array}$

$\begin{array}{ll}\text { 4.4.3.3. Freeze resistance } & 158\end{array}$

4.5. Deposit characterization 160

$\begin{array}{lr}\text { 4.5.1. Regional mining districts } & 160\end{array}$

4.5.2. Structural framework and controlling factors of the deposit 162

$\begin{array}{lr}\text { 4.5.3. Mining techniques in Uruguay } & 167\end{array}$

$\begin{array}{ll}\text { 4.5.4. Economic aspects } & 168\end{array}$

4.5.4.1. Estimation/evaluation of the deposits 168

$\begin{array}{ll}\text { 5. Conclusions } & 175\end{array}$

6. General appendix: Analytical procedures 191

6.1. Density and Porosity, Mercury Injection Porosimetry and

$\begin{array}{ll}\text { Water Absorption } & 191\end{array}$

6.2. Expansion Properties: Thermal and Hydric Expansion 192

6.3. Mechanical Properties 192

6.4. Color measurements 195

$\begin{array}{ll}\text { 7. References } & 197\end{array}$

$\begin{array}{ll}\text { Acknowledgment } & 216\end{array}$

$\begin{array}{lr}\text { Curriculum Vitae } & 219\end{array}$ 


\section{General introduction}

Dimensional stones are noble materials that have been used since the ancient world for the construction of pieces of art and architecture of great importance like temples, monuments, sculptures, fortified walls and castles. The Pyramids in Egypt, the Parthenon and the Aphrodite of Milo in Greece are witness of the resistance of the dimensional stone against the passing of time. Until nowadays, dimensional stones are appreciated due to their petrophysical properties that determine their durability and resistance, and the variety of color and fabrics that they offer.

Their applications had partially changed from a structural use to a more decorative one. The granitic dimensional stones are at present mainly commercialized as polished slabs of one to three centimeters thickness and several quadratic meters in area. These slabs are applied, for example, as façade cladding, countertops and floor slabs. Slates and other similar fissile dimensional stones are used mainly as small tiles for wall and façade cladding as floor slabs.

The world production of dimensional stones has been growing since the beginning of the last century, multiplying by 88 between the years 1926 and 2007 (Montani, 2008). According to Montani (2008), the main dimensional stones exploited, both in 1926 and 2007, were marble and travertine. But while in 1928 the second most produced dimensional stone were the slates and similar rocks, in 2007 the commercial granites occupied this position.

In Uruguay the dimensional stones have been mined since the beginning of the colony end of $17^{\text {th }}$ century with the construction of fortress and citadels. The main materials used were granitic and metamorphic rocks, as it can be seen in the citadels of Montevideo and Colonia del Sacramento and the fortress of Santa Teresa.

During the second half of the $20^{\text {th }}$ century there were numerous quarries active in the country, which mined dolerites (commercially named "black granite"), granitoids, syenitoids, marbles, slates and sandstones. The most valuable dimensional stone is the dolerite, because of its deep black and dark gray colors and high quality 
petrophysical properties. The colors offered by the other Uruguayan dimensional stones are white, gray and various shades of pink, red and greenish-gray.

At the beginning of the 21th century just a few of the dimensional stone quarries are still in operation. These quarries mine dolerite, gray granite, slate and sandstone; all the others are actually inactive or abandoned since many decades. Many of these quarries are still potent of immense reserves that could make a profitable exploitation, but in many cases these reserves are unknown. The mining infrastructure in Uruguay mainly consists of two big industrial sawmills with technology to process large blocks for the production of polished slabs.

Previous scientific research in Uruguay in these minerals resources is scarce. The main efforts in developing scientific knowledge were focused on the granitic dimensional stones, mainly on the dolerites (Bossi and Navarro, 1982; Bossi et al, 1989; Bossi and Campal, 1991) and other commercial granites (Bossi and Navarro, 2000; Morales Pérez, 2004; Morales Pérez and Muzio, 2005; Oyhantcabal et al, 2007a). The petrophysical properties have been previously investigated by Comunità Economica Europea-Uruguay (no date).

Hoffman (2006) and Hoffmann and Siegesmund (2007) investigated the dimensional stone potential of Thailand, with special focus on their deposits and petrophysical characterization. In Argentina a similar research was conducted by Mosch (2008) and Mosch et al (2007). The larvikites of Norway are internationally known commercial granites, which have been studied in detail by Heldal et al (2008). In São Paulo, Brazil, Artur et al (2001) did an exemplary study on the granitic batholith of Socorro from the petrophysical point of view.

The main objective of the present work is to contribute to the scientific research in the field of dimensional stones and their exploitation in Uruguay. Despite the investigation presented a substantial contribution is considered to the development of the sector of dimensional stones, which requires further exploration, evaluation, mining and marketing of the valuable mineral resources that the dimensional stones represent. 
More particular objectives are:

1. The identification of the dimensional stones mined in Uruguay and the evaluation of their geological setting, petrography, geochemistry, petrophysical properties and deposit characteristics.

2. A contribution to the development of standard research methodologies for the prospection, exploration, evaluation and mining of the most important types of dimensional stones in Uruguay.

3. The development of objective criteria for the international standardization of the evaluation methods for dimensional stones.

The relevance and the representativeness of the dimensional stone varieties studied in the present research ruled their selection. Dolerites, gray granitoids, pink- and reddish- colored syenitoid, greenish-gray granite and dolomitic slates are analyzed from the petrographical, geochemical and petrophysical points of view, as well as their deposits are characterized.

The analytical procedures applied can be divided in field and laboratory methods. The field methodologies are the conventional ones for the geological exploration, for example compilation of previous geological investigations and mining records to detailed structural analysis of the quarries. New methodologies are applied in order to determine the possibly largest block size being mined in respect to their joint set distribution. Arithmetic methods (e.g. Singewald, 1992; Sousa, 2010) are compared to three dimensional ones (3D Block Expert software, Nikolayev, 2007).

The laboratory methods applied include petrographical analyses, such as mineral optic microscopy, X-ray difractometry and fluorescence spectrometry. The petrophysical analyses for the assessment of pore space properties and water absorption behavior included the determination of porosity, density, pore radii distribution, water immersion evaluation, capillary, forced and unforced water 
| General introduction

absorption, water vapor diffusion, thermal and hydric expansion. Finally the petromechanical tests include uniaxial compressive strength, tensile strength, flexural strength, abrasion strength, breaking load at the dowel hole. Color measurements were performed in the several black dimensional stones.

The present work is divided in six main chapters: i. general introduction, ii. case study on dolerites, iii. case study on granitoids and syenitoids, iv. case study on slates, v. conclusions and vi. analytical procedures. The case studies are organized in relation with the relevance of the different groups of dimensional stones considered. 


\section{Case study: Dolerites}

\section{Abstract}

Dimensional stones with a black color occupy a prominent place on the international market. Uruguayan dolerite dikes of andesitic and andesitic-basaltic composition are mined for commercial blocks of black dimensional stones. A total of 16 dikes of both compositions were studied and samples collected for geochemical and petrographical analysis. Color measurements were performed on different black dimensional stones in order to compare them with the Uruguayan dolerites. Samples of the two commercial varieties (Absolute Black and Moderate Black) were obtained for petrophysical analysis (e.g. density, porosity, uniaxial compressive strength, tensile strength, etc.). Detailed structural analyses were performed in several quarries. Geochemistry and petrography determines the intensity of the black color. The Uruguayan dolerite Absolute Black is the darkest black dimensional stone analyzed in this study. The petrophysical properties of Uruguayan dolerites make them one of the highest quality black dimensional stones. Structural analyses show that five joint sets have been recognized: two sub-vertical joints, one horizontal and two diagonal. These joint sets are one of the most important factors that control the deposits, since they control the block size distribution and the amount of waste material.

\subsection{Introduction}

Black dimensional stones are known on the international market as "black granites" because their hardness and strength are similar to those shown by granitic rocks. Petrologically these rocks are classified as gabbros, norites, diorites, dolerites (or its synonym: diabase), basalts and anorthosites. Five of them are considered mafic rocks, except for anorthosite, which is classified as a felsic rock.

The Uruguayan Dolerite Dike Swarm, which intruded the Río de la Plata Craton at $1790 \pm 5 \mathrm{Ma}$ (Halls et al, 2001) is composed of hundreds of parallel dikes with an average width of 30 meters and average lengths of around 1,000 meters. In Uruguay they have been quarried since the early 1960s due to their deep black color, which is always en vogue, and their excellent technical properties, such as extremely high 
uniaxial compressive strength (UCS) and remarkable low porosity and water uptake. These dimensional stones are used as high quality cladding, worktops, bathroom vanities, tombstones and precision tables.

Due to their physical properties and appearance, these rocks have been quarried since the time of ancient Egypt, where they were used for the construction of sacred monuments (tombs and temples) or magnificent buildings (palaces) (Ashurst and Dimes, 1998). They were also utilized for the production of various decorative elements, such as valuable pieces of art (e.g. statues, fountains, etc.). Over the centuries and even today, dolerites and other black dimensional stones are used for representative buildings and other constructions worldwide.

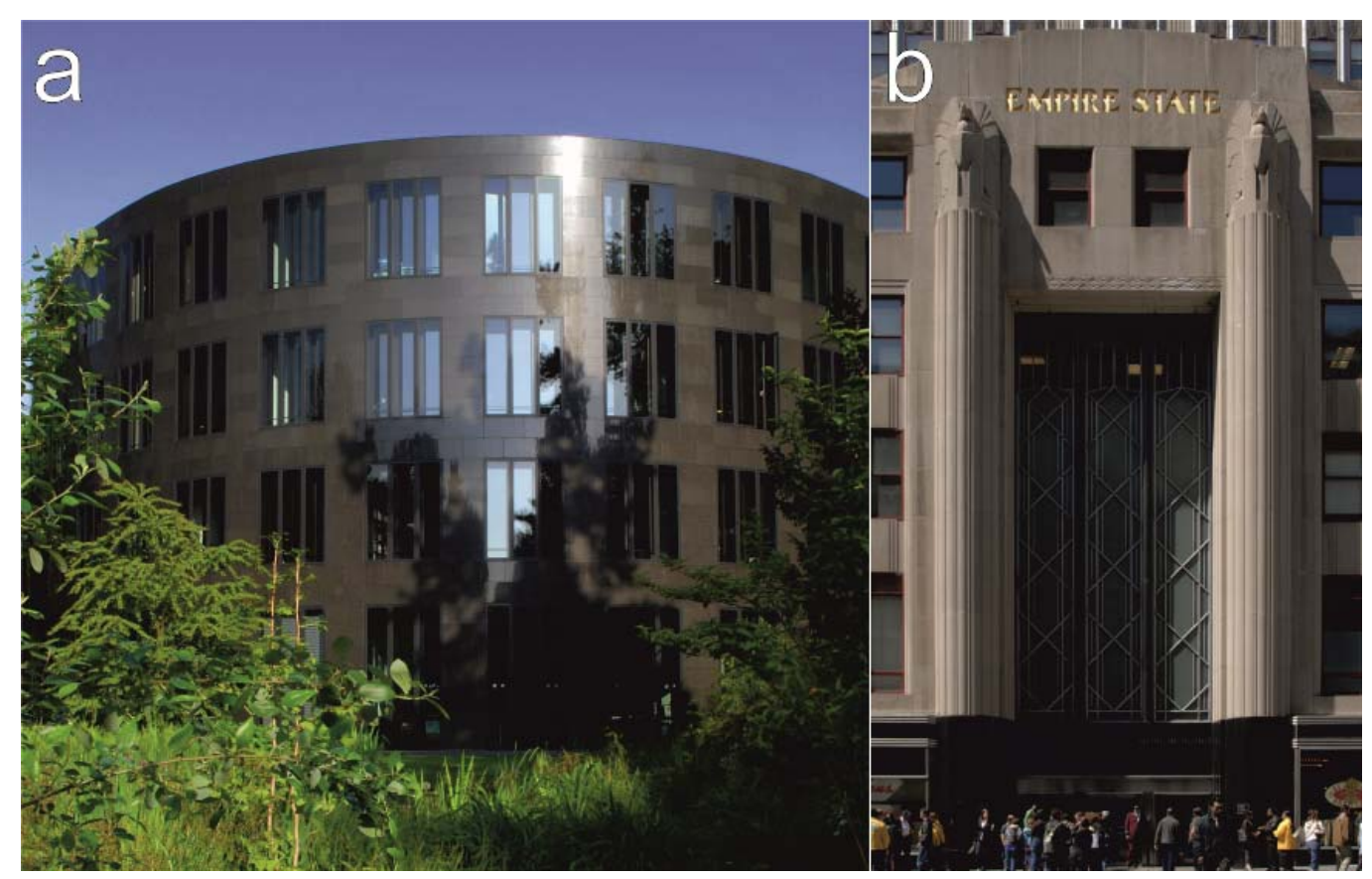

Fig. 2.1: Examples of applications of black dimensional stones: a. Empire State Building (New York, USA) façade made of Ebony Black from Sweden; b. Office of the Federal President in Berlin (Germany) made of Impala Dark from South Africa.

Examples of the use of black dimensional stones in Germany can be found in the Düsseldorf Airport, which uses the Shanxi Black (dolerite) from northern China for the interior flooring tiles. The Office of the Federal President in Berlin uses the Impala Dark (gabbro/norite) for the building façade (Börner and Hill, 2010) (Fig. 2.1a) and in Bad Homburg the footbridge masts are constructed of Nero Assoluto (gabbro) from Zimbabwe (Fig. 2.2). In the United States of America the base façade of the Empire 
State Building utilizes Ebony Black (dolerite) from Sweden (Ashurst and Dimes, 2004) (Fig 2.1b) and in Uruguay the entrance columns of the Antel Tower are made of Uruguayan Black Absolute dolerite.

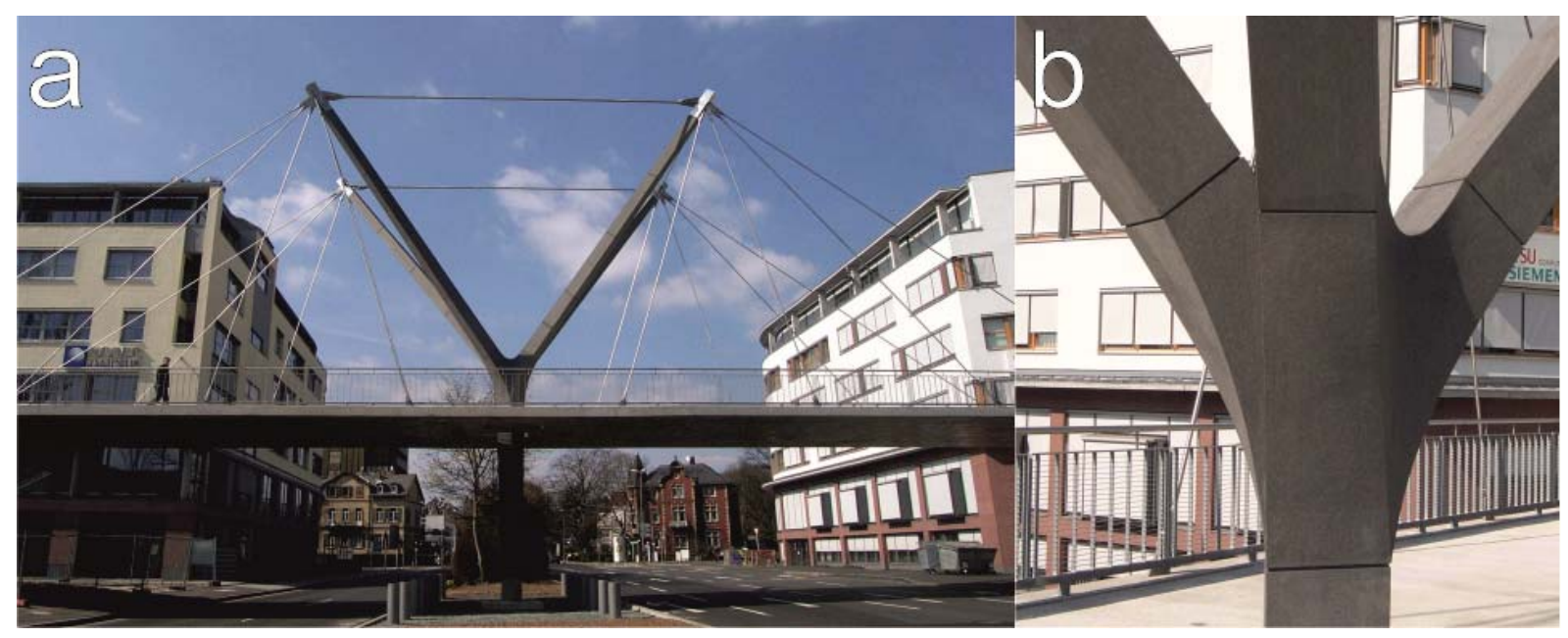

Fig. 2.2: Footbridge in Bad Homburg (Germany) made of Nero Assoluto from Zimbabwe (Source: SBP $\mathrm{GmbH})$ : $\mathbf{a}$. General view of the footbridge; $\boldsymbol{b}$. Detail of support mast.

The prices for black dimensional stones on the international market vary from 900 to $2,400 \mathrm{US} \$ / \mathrm{m}^{3}$, whereas the Uruguayan dolerites are priced at 900 to $1,700 \mathrm{US} \$ / \mathrm{m}^{3}$. Dolerites from China have prices ranging from 1,000 to 2,000 US $\$ / \mathrm{m} 3$, the South African gabbro/norite shows prices up to $2,000 \mathrm{US} \$ / \mathrm{m}^{3}$ and the most expensive black stone is the iridescent norite from India with a price of $2,400 \mathrm{US} \$ / \mathrm{m}^{3}$. Prices depend on two aspects: the intensity of the black color (the darker the stone, the more expensive it is) and the block size (the largest blocks are relatively more expensive).

\section{Present mining situation}

In Uruguay the methods of mining dolerites have evolved since the 1960s when quarrying began. Mining was initially done by manual extraction and then evolved by using the modern technique of the diamond wire saw, which has proven to be a highly effective method.

The different periods in the production of dolerite blocks are closely related to specific economic cycles in Uruguay (Fig. 2.3). Since the beginning of production in 1960 and until the end of the 1970s it was a period of slow growth, with a maximal annual 
production of around 1,000 tons. This first growth period was probably favored by the initial support that the mining and geological sector received from the military dictatorship during the period of 1973 to 1985 . By the end of the 1970s, the government implemented a macroeconomic deflation plan via a pre-announced decrease of the exchange rate. Thus, Uruguayan products became more expensive than they really were and in the long run the exporters lost their competitiveness. This situation lasted until 1982, when the country was in the middle of a deep crisis. The government stopped bolstering the Uruguayan peso to the US dollar, leading to a strong devaluation of the national currency. In these years dolerite production suffered a sharp decline, of almost $90 \%$ in the deepest moment of the crisis with respect to that of the year 1978, which had the highest level of production on record.

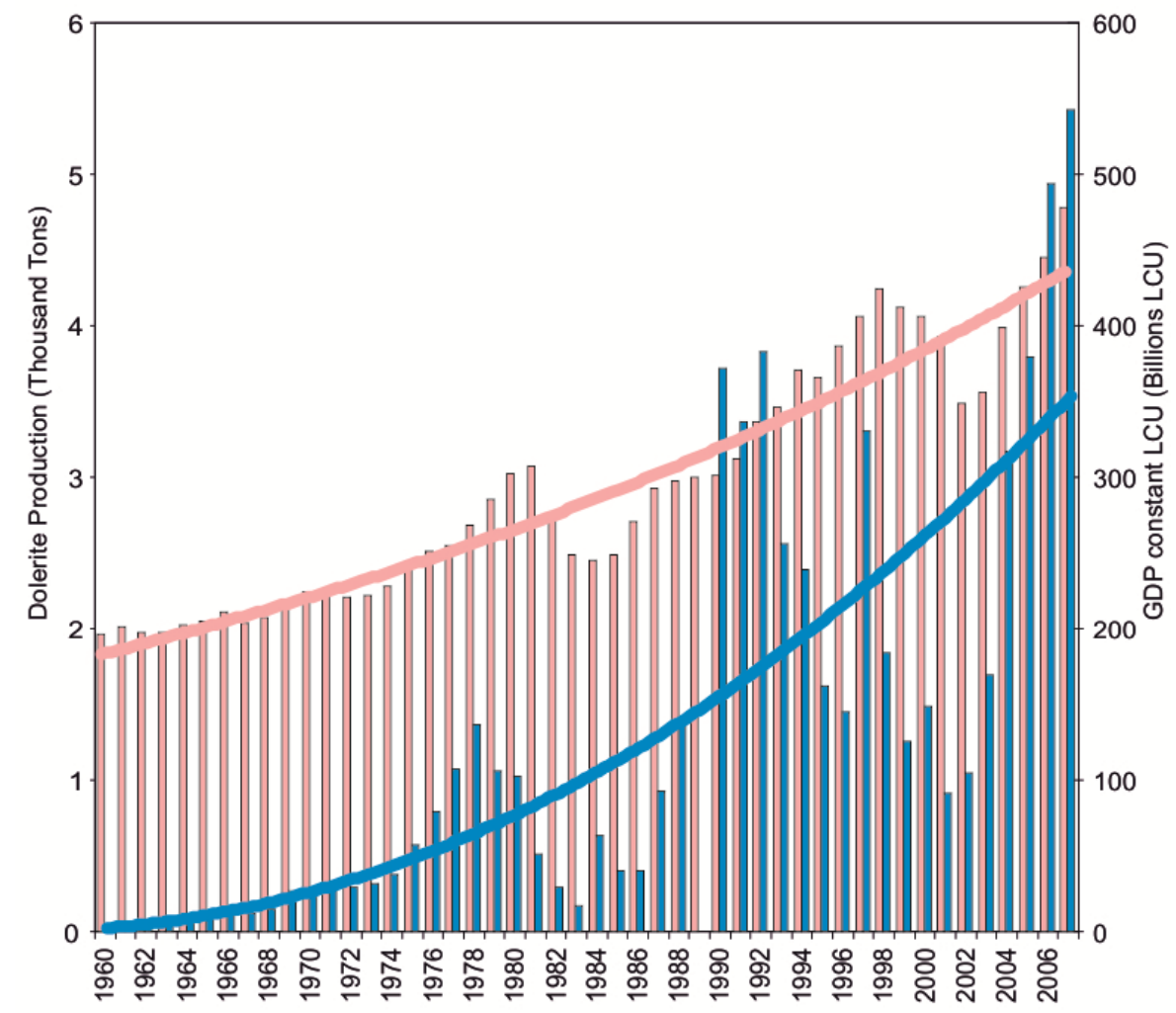

— Dolerite Production (Ton) $\square$ GDP (constant LCU)

Fig. 2.3: Evolution of dolerite production in Uruguay (data after Bossi and Campal 1991; Morales Pérez 2004 and DINAMIGE 2010) and GDP (Gross Domestic Product) in constant local currency units (LCU) (data after World Bank homepage, 2010).

Afterwards, the production entered into a new phase of growth until the beginning of the 1990s, which was related to regional/national growth cycles and the entry of new 
investors in the stone sector. A new period of stagnation in dolerite production occurs at the beginning of the 1990s, when the national economy entered into a new recession phase. In the years 2001-2002, this period of recession turns into a severe crisis, accompanied with a new devaluation of the national currency. Dolerite production reaches the lowest level in the last 10 years, but as the economy recovers so does the production of black dimensional stone.

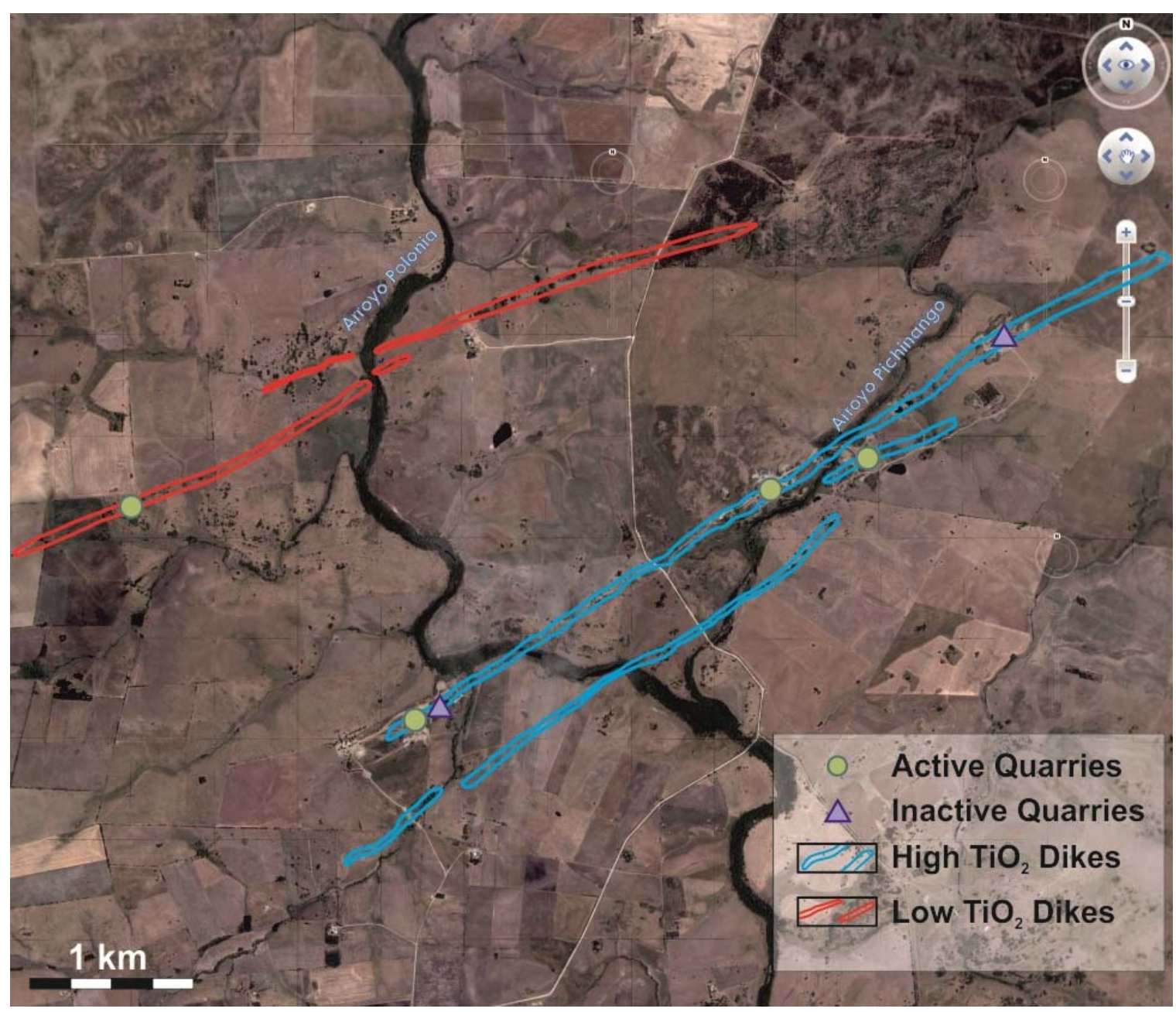

Fig. 2.4: Satellite image showing different dolerite dikes in the region of Polonia-Pichinango with active and inactive quarries (Image Source: Google Earth, 2010).

Today production is in a new growth phase, mostly influenced by the positive market trend for "Absolute Black", which as of 2005 is due to the demand for stones of black color. Despite the facts that in the present only three companies are quarrying the dolerite dikes, the production in the last several years has exceeded the average of the last 45 years (Fig. 2.3). This can be directly related to the use of the diamond wire 
saw, which that increases the efficiency of the extraction, and the recent trade policy strategy that promotes the export of these products.

Historically there have been 19 quarries, four of which mined only superficial blocks. The quarries now active are distributed in two regions in the Department of Colonia, one in the region of Arroyo de la Quinta, and the other in the region of PoloniaPichinango (see Fig. 2.4). Two quarries are located in the same dike. Two large active sawmills are in operation in the region, which cut the blocks extracted from the quarries, produce polished slabs and sell the products on the national and international markets. One sawmill is located in Nueva Palmira with access to a harbor. The other sawmill is located in Las Piedras, $25 \mathrm{~km}$ away from the main harbor in Montevideo (Uruguay). Both harbors have the facilities to ship the blocks and other processed materials such as polished slabs. Numerous small sawmills in the country buy the already polished slabs.

The non-metallic mineral export of Uruguay in the year 2007 was around $4.4 \%$ of the total export of the country. No information on the amount of dimensional stone exports is available.

In the last ten years the dimensional stone sector in Uruguay has been represented by the production of granite and syenite (red, pink, gray and dark green), slate (black, gray, red and green), dolerite (black and dark gray), marble (white) and recently sandstone (orange and yellow) (Fig. 2.5). Granite and syenite production (plotted together in Fig. 2.5) has decreased in the last ten years as dolerite production has grown. Marble production is marginal and sandstone has entered the market in 2003 with its production continuing to grow. Slate production has remained more or less constant in the last ten years. The strong decrease in the production of granite and syenite reflects the growing predominance of China as an exporter of these products.

The production of dimensional stones in the year 2004 represents around $0.26 \%$ of the non-metallic mineral production (in tons). The dolerite production for the same year is about $22 \%$ of the total dimensional stone production (in tons). In US\$ the dolerite production is almost $40 \%$ of the total dimensional stone production 
(DINAMIGE, 2010). This makes dolerite the most important dimensional stone product of Uruguay.

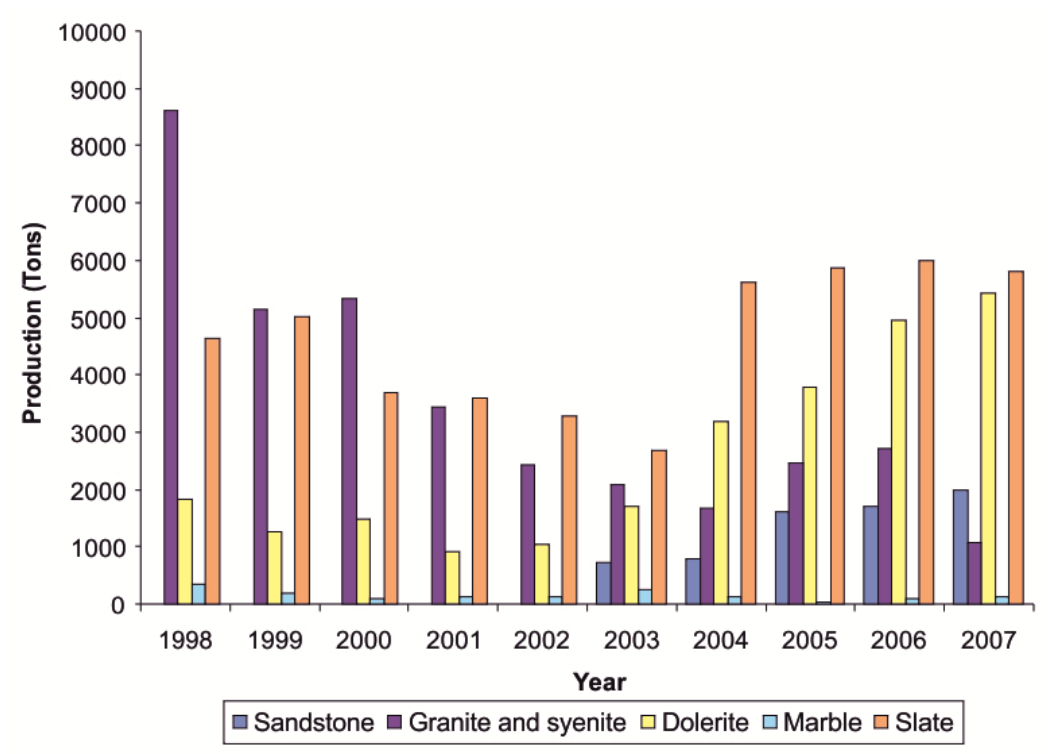

Fig. 2.5: Dimensional stone production in tons (from DINAMIGE, 2010).

Data for granites and syenites are combined.

The world demand for black dimensional stones of high quality is not yet totally covered by the other productive countries such as China, South Africa, Sweden, Zimbabwe, India, and Brazil. Uruguay, whose production is not very large at the present time, will probably occupy a more constant position on the world market when more dolerite dikes are developed for production.

2.2. Geological setting of the dolerite dike swarm in Uruguay

The geology of Uruguay is characterized by a Precambrian basement that crops out in the south part of the country. This basement was originally divided into two regions by Ferrando and Fernandez (1971), taking into account their ages: the eastern domain belonging to the Brasiliano Cycle (Neoproterozoic) and the western to the Transamazonian Cycle (Paleoproterozoic).

The Río de la Plata Craton was defined by Almeida (1971) including the Transamazonian outcrops of southern Brazil, Uruguay and Argentina. Fragoso-Cesar (1980) defined the Dom Feliciano Mobile Belt of southern Brazil and Uruguay, as a series of petrotectonic associations of Brasiliano age. 


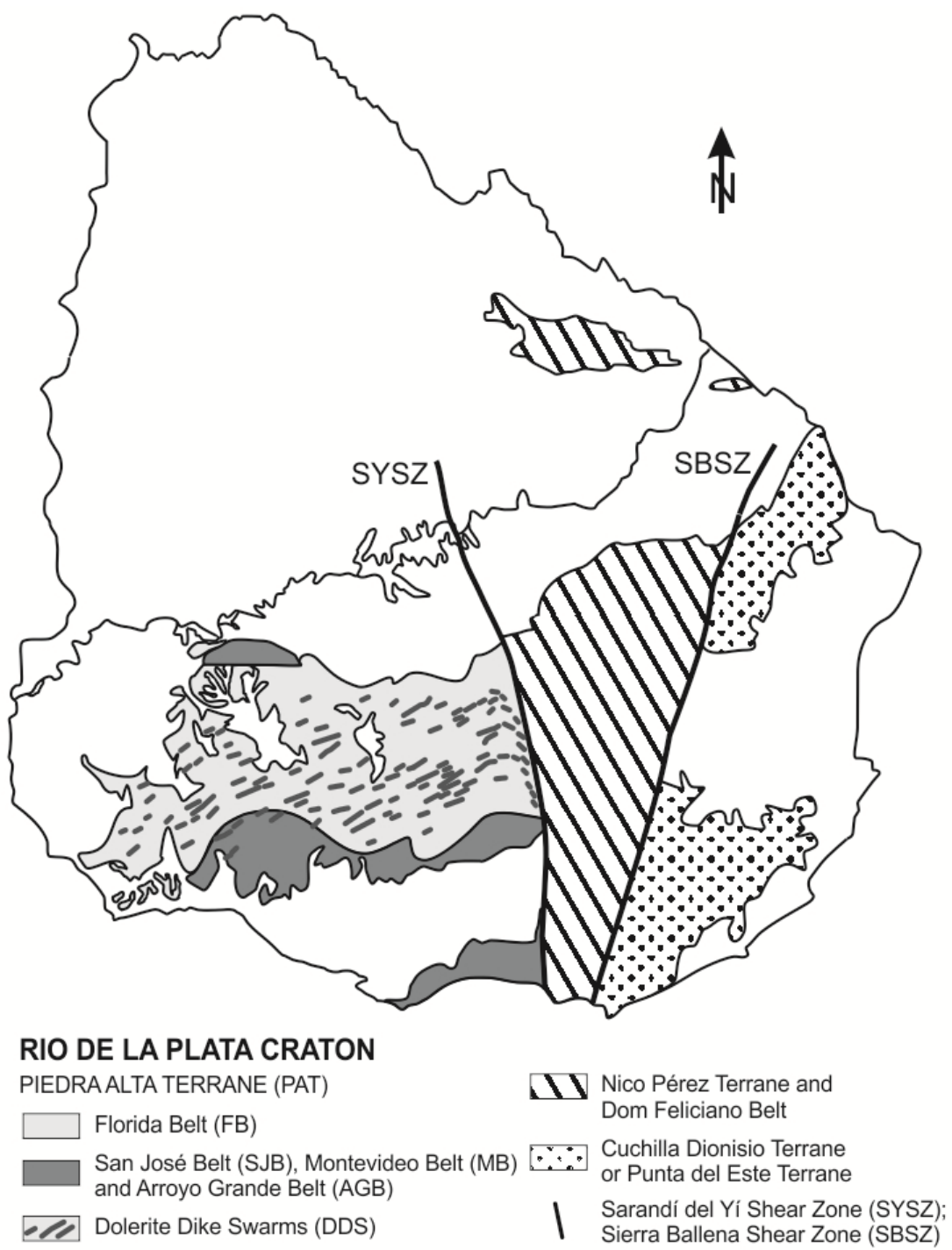

Fig. 2.6: Schematic geological map of Uruguay (modified from Hartmann et al, 2001).

Bossi and Ferrando (2001) divided the Uruguayan basement into three tectonostratigraphic terranes: the Piedra Alta and the Nico Pérez Terrane (these two terranes correspond to the Río de la Plata Craton) and the Cuchilla Dionisio (corresponding to the Dom Feliciano Mobile Belt). These terranes are separated from west to east, by two first order tectonic regional discontinuities: Sarandi del Yí and Sierra Ballena Shear Zones (Fig. 2.6).

Recently, Oyhantçabal et al (2010) proposed a redefinition of the Río de la Plata Craton, based on new and previously published geochronological and isotopic data that shows different events of crustal growth and crystallization ages for the Piedra 
Alta and Nico Pérez Terrane. These differences support the exclusion of the Nico Pérez Terrane from the Río de Plata Craton, which now comprises the Piedra Alta Terrane in Uruguay and the Tandilia Belt in Argentina.

The Piedra Alta Terrane is especially significant for this work because it contains the dolerite dike swarm. According to Oyhantçabal et al (2007), this terrane is composed of two supracrustal metamorphic belts with an E-W direction. Each one of them is composed of a metamorphic volcanic-sedimentary formation and spatially associated plutonic bodies, and extended granitic-gneissic belts in between (Bossi and Ferrando, 2001).

The metamorphic belts are from north to south: the Arroyo Grande Belt and the San José Belt. The first one was defined by Bossi and Ferrando (2001) and corresponds to the Arroyo Grande Formation (a folded volcano-sedimentary succession of greenschist facies, Oyhantçabal et al, 2010) and associated intrusions formerly defined by Ferrando and Fernandez (1971). The San José Belt comprises the Paso Severino Formation and associated intrusions, the San José Formation and the Montevideo Formation (Oyhantçabal et al, 2007b). The Paso Severino Formation, as defined by Oyhantçabal et al, 2010 consists of a greenschist facies folded volcanosedimentary succession. The San José Formation is composed of paragneisses and garnet and staurolite-bearing micaschists (Oyhantçabal et al, 2003; 2007). The Montevideo Formation comprises amphibolites, paragneisses and garnet and staurolite-bearing micaschists (Bossi, 1965; Bossi et al, 1993; Oyhantçabal et al, 2003; 2007).

Between these belts there are elongated granitic-gneissic areas that also include decameter to kilometer-sized blocks of micaschists, paragneisses and amphibolites. These areas are known as the Florida Central Granitic-Gneiss Belt (Bossi and Ferrando, 2001; Oyhantçabal et al, 2010).

The tectono-thermal activity of this terrane, and therefore the Río de la Plata Craton, consists of two Transamazonian events at 2.2 - 2.1 and 2.1 - 2.05 Ga (Oyhantçabal et al, 2010). An anorogenic event occurs with the intrusion of the basic dike swarm in 
an extensional regime (Bossi and Ferrando, 2001) at $1790 \pm 5 \mathrm{Ma}$ (U-Pb on baddeleyite by Halls et al, 2001). This swarm encompasses an area of $25,000 \mathrm{~km}^{2}$ (100 km width and $250 \mathrm{~km}$ length) with a general trend of ca. $060^{\circ}$ and intrudes in all the lithologies of the Florida Central Granitic-Gneiss Belt (Bossi and Campal, 1991). This mafic dike swarm (Bossi et al, 1993) is also known as the Uruguayan Dike Swarm (Teixeira et al, 1999; Halls et al, 2001) or the Florida Dyke Swarm (Mazuchelli et al, 1995).

The craton was stable for a long time after the intrusion of the basic dike swarm, until the last event at the end of the Proterozoic, when its edge was reworked by a dextral mega-shear known as the Sarandí del Yí Shear Zone. This event caused the rotation of the eastern extreme of the dike swarm to the south (Bossi and Campal, 1991).

\subsection{Characterization of the dolerite deposits}

In Uruguay a wide spectrum of names are used to describe these rocks. They have been called "black granites" (mostly in the commercial sector; Bossi and Navarro, 1982; Bossi et al, 1990; Techera et al, 2004; Comunità Economica EuropeaUruguay, no date), microgabbros (Bossi and Navarro, 1982; Bossi et al, 1989; Bossi and Campal, 1991; Bossi et al, 2000; Spoturno et al, 2004), andesitic and andesiticbasaltic dikes (Bossi and Campal, 1991; Bossi et al, 1993; Bossi and Ferrando, 2001), gabbros (Comunità Economica Europea-Uruguay, no date) and in the recent literature dolerites (Oyhantçabal et al, 2006; 2007; 2008).

The term dolerite, synonymous with diabase and microgabbro, is used to describe an igneous hypabyssal rock of dark color composed of plagioclase (labradorite in composition) and clinopyroxene (normally augite or titanoaugite), with opaques as the main accessory minerals (magnetite, titanomagnetite or ilmenite). The grain size is between that of gabbro and basalt (medium-grained, between 1 and $5 \mathrm{~mm}$ ) and the typical texture is ophitic or subophitic (laths of plagioclase totally or partially surrounded by crystals of augite) (Allaby and Allaby, 1990; Jackson, 1997).

Campal and Garat (1990) and Bossi and Campal (1991) studied and related the petrographic characteristics to the geochemical features, dividing the dike swarm into 
two groups. One group comprises rocks of of andesitic composition and high titanium content (Group A) and the other one of andesitic-basaltic composition and low titanium content (Group B). In the present work these two groups were also recognized.

Table 2.1: Dike width and grain sizes in Zones 2 and 3.

\begin{tabular}{|c|c|c|c|c|c|}
\hline \multirow{2}{*}{ Group } & \multirow{2}{*}{ Sample } & \multirow{2}{*}{ Quarry/Location } & \multicolumn{2}{|c|}{ Grain size (mm) } & \multirow{2}{*}{$\begin{array}{c}\text { Dike } \\
\text { Width (m) }\end{array}$} \\
\hline & & & Zone 2 & Zone 3 & \\
\hline \multirow{10}{*}{$\begin{array}{c}\text { Group A } \\
\text { (High } \\
\left.\mathrm{TiO}_{2}\right)\end{array}$} & U215 & La Sierra & 0.68 & & 16 \\
\hline & U62 & Las Acacias & 0.40 & 1.00 & 19 \\
\hline & U12B & Talita Chica & & 1.70 & 20 \\
\hline & U12A & Talita Grande & & 1.70 & 25 \\
\hline & U55 & Mexico & 0.60 & 1.30 & 30 \\
\hline & U56 & Los Fresnos & & 1.70 & 30 \\
\hline & U64 & Pintado & 0.44 & 1.70 & 35 \\
\hline & U11 & Blackstone & 0.80 & 1.50 & 38 \\
\hline & U59 & Omar Mendez & 0.65 & 2.00 & 40 \\
\hline & U8 & Rosarito & 0.45 & 1.80 & 41 \\
\hline \multirow{6}{*}{$\begin{array}{c}\text { Group B } \\
\text { (Low } \\
\mathrm{TiO}_{2} \text { ) }\end{array}$} & U199 & Arroyo Polonia & 0.60 & & 20 \\
\hline & U66 & Pimafox & 0.76 & 1.65 & 24 \\
\hline & U61 & Inex S.A. & 0.20 & & 25 \\
\hline & U13 & Victor & 0.40 & 1.50 & 30 \\
\hline & U58 & Boria & 0.50 & & 30 \\
\hline & U243 & Arroyo de la Quinta & & 1.75 & 30 \\
\hline
\end{tabular}

In each dike it is possible to recognize three zones when taking into account the grain size (see Fig. 2.7 and 2.8 and Table 2.1). Figure 2.9 depicts the distribution of the different zones. Zone 1 is in contact with the country rock; its thickness is not more than $60 \mathrm{~cm}$, is normally very finely fractured and defines the chilled margin of the dike. Zone 2 is 1 to $1.5 \mathrm{~m}$ thick, is less fractured and characterized by a fine grain that increases towards the middle of the dike. Zone 3 is located in the center of the dike, representing ca. $90 \%$ of the width. The contact with Zone 2 is gradual. The grain size in this zone is medium-grained, ranging from $1 \mathrm{~mm}$ to $2 \mathrm{~mm}$. 


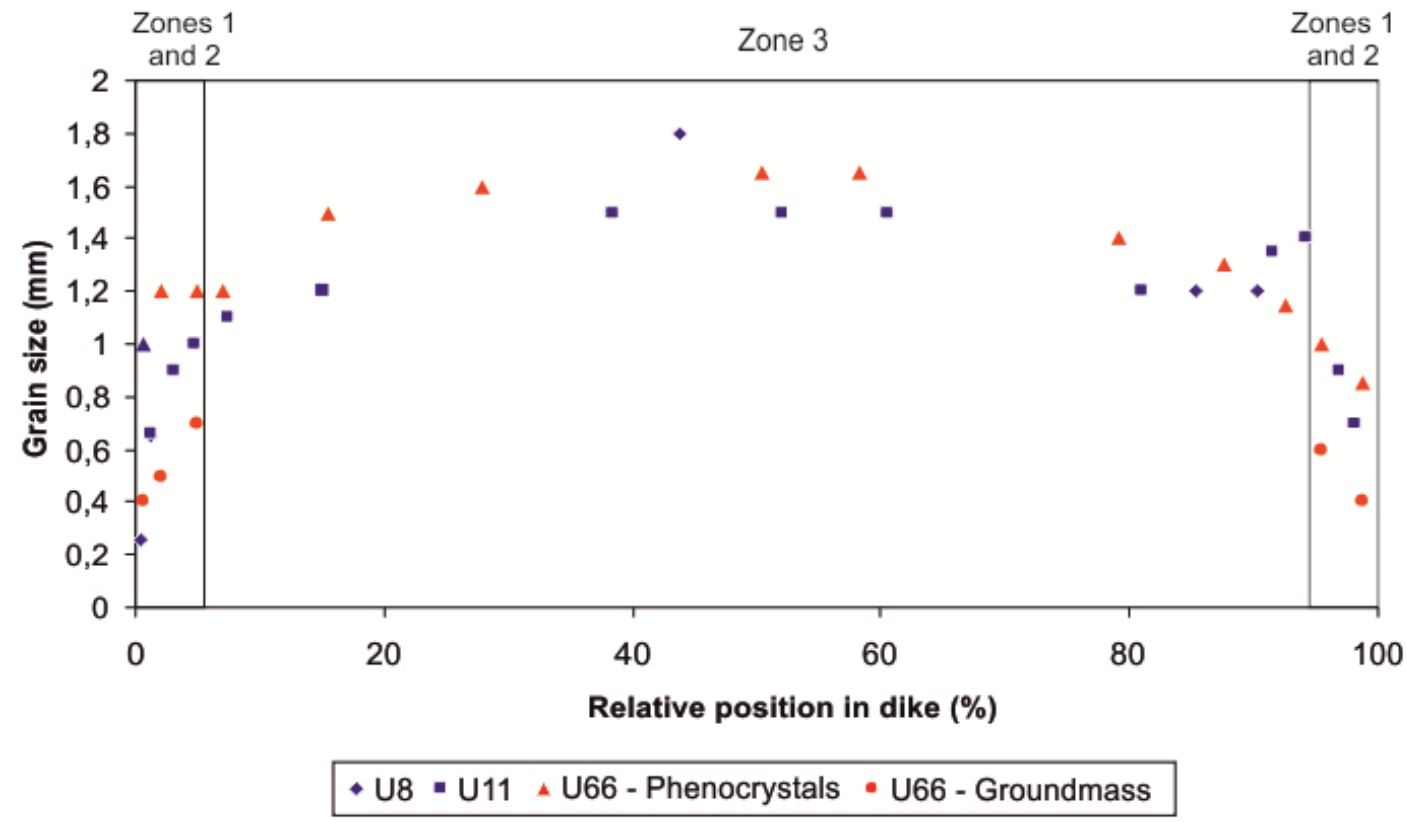

Fig. 2.7: Grain size distribution in three dolerite quarries. High $\mathrm{TiO}_{2}$ : U8 (Rosarito) and U11 (Blackstone); Low $\mathrm{TiO}_{2}$ : U66 (Pimafox). Grain size of phenocrysts and groundmass separated.

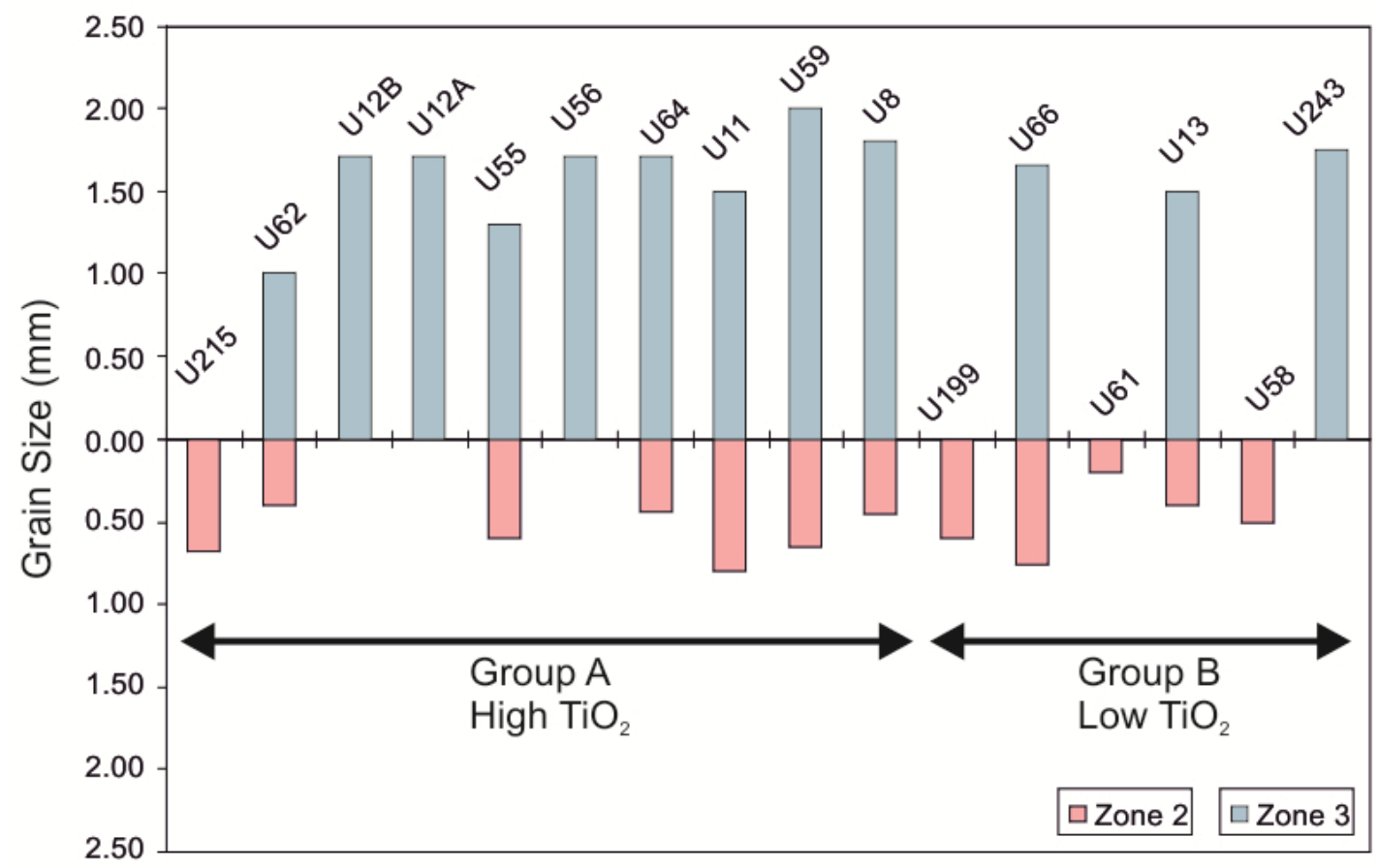

Fig. 2.8: Grain sizes in Zones 2 and 3 for both dike groups.

In the three quarries where a grain size profile was taken and analyzed, observations indicate that Zones 1 and 2 on both sides of the dike represent not more than $11 \%$ of the dike width (Fig. 2.7). As shown in Table 2.1, no strong correlation between the 
dike width and the maximal grain size exists, although the wider dikes (for example U8 and U59) show the coarser grain and the finer dikes (as the case of U62) show the finer grain. Further investigations are still necessary to clarify this observation.

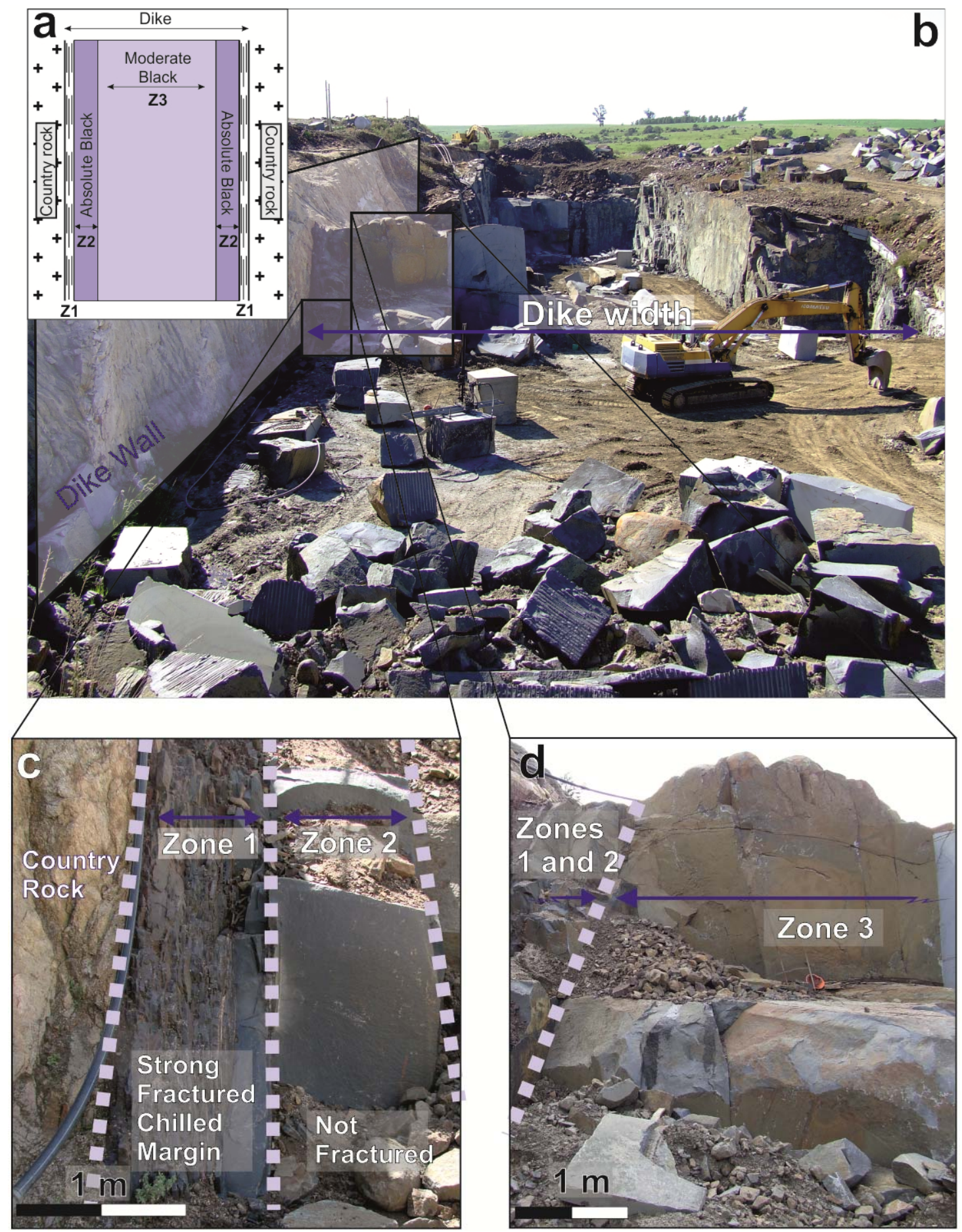

Fig. 2.9: Black Stone Quarry in dike of Group A. a. Schematic figure where Zones 1, 2 and 3 (Z1, Z2 and $Z 3$, respectively) are represented; b. General view of quarry, contact with country rock is shown; c. Contact zone of dike with the country rock. Strongly fractured chill margin (Zone 1), not fractured Zone 2; d. Zone 3, with few horizontal and vertical joints. 


\subsubsection{Geochemistry}

Major and minor elements were determined by $\mathrm{x}$-ray fluorescence spectrometry. A total of 24 samples from 14 dikes were already investigated by Bossi et al (1993) and a total of 28 samples from 16 dikes were analyzed in this study. Another five dikes were identified but they were unreachable for samples collection. In some dikes two samples were analyzed, one from Zone 2 (fine-grained) and the other from Zone 3 (medium-grained), in order to ascertain the geochemical differences that can be correlated to the petrography of these rocks.

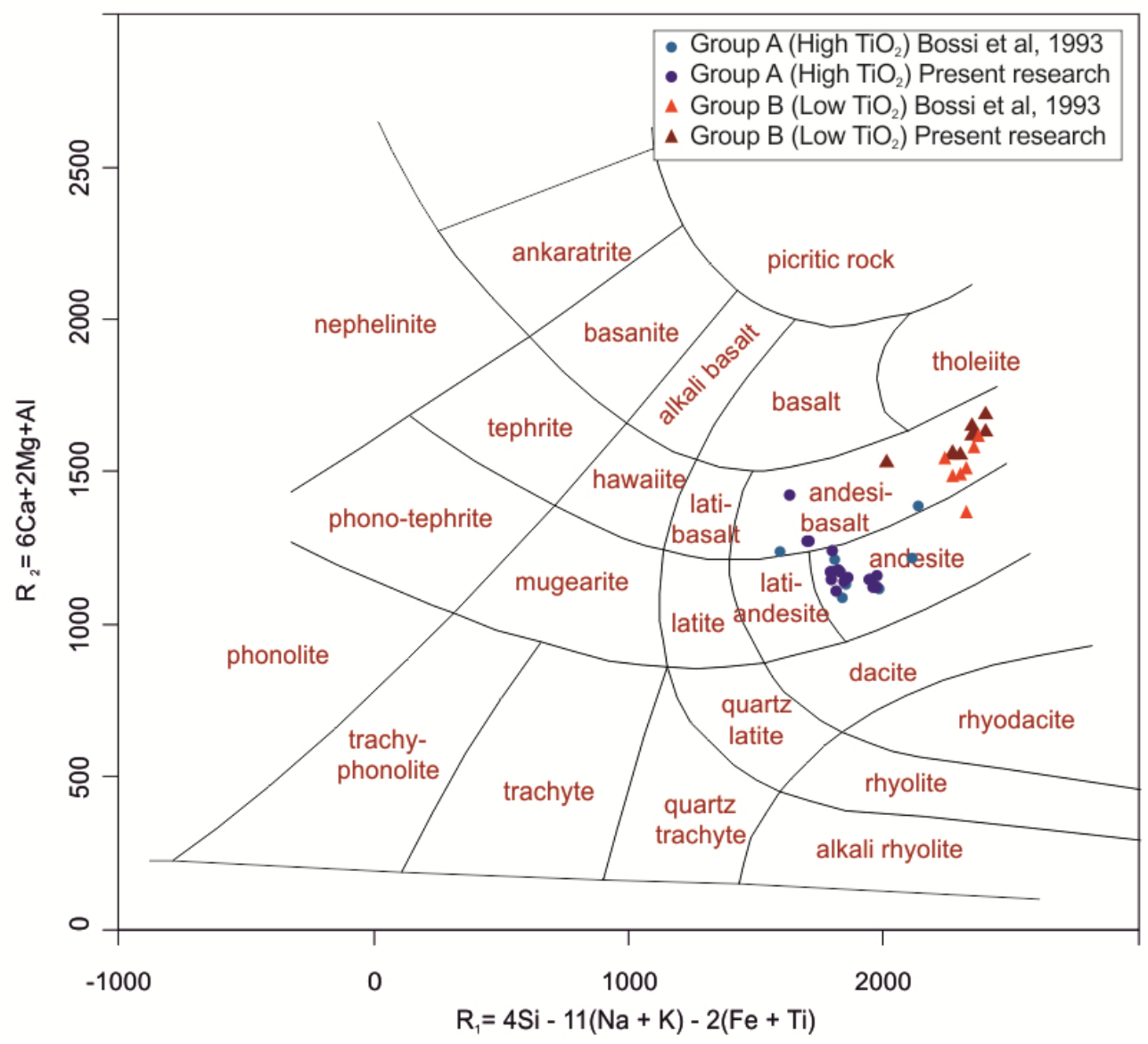

Fig. 2.10: Distribution of the dikes in a R1-R2 diagram (after De La Roche et al, 1980).

The results of these analyses (Tables 2.2 and 2.3) corroborate the observations made by Bossi and Campal (1991), who divided the dikes into two groups based on their geochemistry that correspond to the two petrographic groups. Group $A$ is characterized by relatively high contents of $\mathrm{TiO}_{2}$ (between 1.5 and 2.5\%) and an andesitic composition, and Group $\mathrm{B}$ is defined by relatively low contents of $\mathrm{TiO}_{2}$ 
$(<1.2 \%)$ and an andesitic-basaltic composition. This is shown in the De La Roche diagram in Figure 2.10. Group A also shows relatively higher values for the other major elements: $\mathrm{FeO}_{\mathrm{t}}, \mathrm{MnO}, \mathrm{Na}_{2} \mathrm{O}, \mathrm{K}_{2} \mathrm{O}, \mathrm{P}_{2} \mathrm{O}_{5}$, but lower values of $\mathrm{Al}_{2} \mathrm{O}_{3}, \mathrm{MgO}$ and $\mathrm{CaO}$ (Fig 2.11). They also exhibit different mg\# values $\left(\mathrm{MgO} / \mathrm{MgO}+\mathrm{FeO}_{\mathrm{t}}\right)$, where the values for Group A are around 0.17 and 0.25 and those for Group B are between 0.35 and 0.45 .

Table 2.2: Major elements compositions of the dolerites (in wt\%).

\begin{tabular}{|c|c|c|c|c|c|c|c|c|c|c|c|c|c|c|c|}
\hline Sample & $\mathrm{SiO}_{2}$ & $\mathrm{TiO}_{2}$ & $\mathrm{Al}_{2} \mathrm{O}_{3}$ & $\mathrm{FeO}_{\mathrm{t}}$ & MnO & MgO & $\mathrm{CaO}$ & $\mathrm{Na}_{2} \mathrm{O}$ & $\mathrm{K}_{2} \mathrm{O}$ & $\mathbf{P}_{2} \mathbf{O}_{5}$ & $\mathrm{Fe}_{2} \mathrm{O}_{3}$ & $\mathrm{FeO}$ & $\mathrm{H}_{2} \mathrm{O}$ & $\mathrm{CO}_{2}$ & mg\# \\
\hline \multicolumn{16}{|l|}{ Group A } \\
\hline U8M1 & 54.2 & 2.409 & 12.3 & 13.56 & 0.162 & 2.73 & 6.79 & 2.60 & 1.86 & 0.276 & 1.71 & 12.02 & 1.12 & 0.25 & 0.17 \\
\hline U8P7 & 53.2 & 261 & 12.0 & 14.37 & 0.185 & 3.18 & 7.25 & 2.49 & 1.59 & 0.238 & 1.81 & 12.73 & 0.92 & 0.19 & 0.18 \\
\hline U11A & 55.4 & .733 & 12.9 & 12.54 & 0.173 & 3.04 & 6.97 & 2.58 & 1.75 & 0.224 & 1.58 & 1.11 & 0.63 & .13 & 0.20 \\
\hline U110 & 53.2 & .332 & 12.2 & 14.50 & 0.184 & 3.07 & 7.25 & 2.56 & 1.64 & 0.247 & 1.82 & 12.85 & 0.59 & .09 & 0.17 \\
\hline U11M1 & 54.1 & 2.269 & 12.2 & 13.53 & 0.171 & 2.94 & 6.99 & 2.58 & 1.74 & 0.255 & 1.70 & 11.99 & 1.10 & 0.19 & 0.18 \\
\hline U11M12 & 53.2 & 2.243 & 12.0 & 14.35 & 0.184 & 3.22 & 7.26 & 2.50 & 1.61 & 0.238 & 1.80 & 12.71 & 0.89 & 0.19 & 0.18 \\
\hline U12A & 51.1 & 2.278 & 12.2 & 14.90 & 0.197 & 3.77 & 7.83 & 2.49 & 1.45 & 0.291 & 1.87 & 13.20 & 0.95 & 0.26 & 0.20 \\
\hline U12B & 51.2 & 2.297 & 12.3 & 14.96 & 0.196 & 3.77 & 7.81 & 2.50 & 1.46 & 0.288 & 1.88 & 13.25 & 0.86 & 0.22 & 0.20 \\
\hline U55M1 & 50.2 & 2.419 & 12.9 & 14.10 & 0.205 & 4.26 & 8.22 & 2.56 & 1.51 & 0.369 & 1.77 & 12.50 & 0.95 & 0.24 & 0.23 \\
\hline U55M4 & 53.6 & 2.192 & 11.7 & 14.20 & 0.184 & 3.11 & 7.11 & 2.49 & 1.62 & 0.262 & 1.79 & 12.58 & 1.08 & 0.32 & 0.18 \\
\hline U56 & 53.1 & 2.251 & 11.9 & 14.48 & 0.186 & 3.19 & 7.22 & 2.53 & 1.63 & 0.240 & 1.82 & .83 & 0.88 & 0.20 & 0.18 \\
\hline U59 & 49.4 & 2.380 & 13.0 & 14.32 & 0.212 & 4.81 & 8.63 & 2.46 & 1.37 & 0.343 & 1.80 & 12.69 & 0.80 & 0.25 & 0.25 \\
\hline U62M3 & 55.1 & 1.750 & 12.7 & 12.77 & 0.173 & 2.99 & 6.92 & 2.55 & 1.76 & 0.224 & 1.61 & 11.31 & 0.78 & 0.13 & 0.19 \\
\hline U62M6 & 55.2 & 1.782 & 12.7 & 12.83 & 0.175 & 2.98 & 6.93 & 2.57 & 1.78 & 0.223 & 1.61 & 11.36 & 0.74 & 0.21 & 0.19 \\
\hline U64M1 & 53.4 & 2.300 & 12.1 & 14.27 & 0.184 & 2.99 & 7.06 & 2.57 & 1.69 & 0.322 & 1.80 & 12.65 & 0.81 & & 0.17 \\
\hline U64M2 & 52.4 & 2.190 & 12.3 & 14.3 & 0.193 & & 7.64 & & 1.48 & & 1.81 & & & & 0.20 \\
\hline $\mathrm{U} 215 \mathrm{M} 1$ & 55.4 & 1.761 & 12.8 & 12.40 & 0.162 & 2.95 & 6.69 & & 1.82 & 0.226 & 1.56 & & 1.13 & & 0.19 \\
\hline U215M3 & 55.6 & 1.786 & 12.9 & 12.36 & 0.163 & 2.92 & 6.70 & 2.57 & 1.84 & 0.226 & 1.55 & 10.95 & 1.12 & 0.14 & 0.19 \\
\hline \multicolumn{16}{|l|}{ Group B } \\
\hline U13M1 & 52.2 & & 15.5 & & & & & & & & & & & & 0.40 \\
\hline U13M10 & 53.2 & 0.812 & 14.9 & & 0.149 & & 9. & & 0.98 & & 1.0 & & 0.79 & & 0.42 \\
\hline U58M1 & 53.7 & 0.912 & 14.4 & 10.07 & 0.157 & 5.60 & 9.34 & 2.08 & 1.14 & 0.121 & 1.11 & 9.07 & 0.86 & 0.20 & 0.36 \\
\hline U58M3 & 53.8 & 0.873 & 14.2 & 10.00 & 0.158 & 5.67 & 9.32 & 2.04 & 1.08 & 0.116 & 1.10 & 9.00 & 1.16 & 0.33 & 0.36 \\
\hline U61 & 53.9 & 0.929 & 14.5 & 9.94 & 0.150 & 5.44 & 9.34 & 2.09 & 1.17 & 0.123 & 1.09 & 8.94 & 0.89 & 0.17 & 0.35 \\
\hline U66P1 & 53.9 & 0.789 & 14.7 & 9.07 & 0.146 & 6.48 & 9.56 & 1.94 & 0.96 & 0.106 & 1.00 & 8.17 & 0.99 & 0.17 & 0.42 \\
\hline U66P12 & 53.2 & 0.737 & 15.0 & 8.82 & 0.145 & 7.13 & 9.74 & 1.87 & 0.91 & 0.099 & 0.97 & 7.94 & 0.82 & 0.29 & 0.45 \\
\hline U199 & 53.4 & 0.826 & 15.1 & 9.16 & 0.150 & 6.47 & 9.34 & 1.94 & 1.04 & 0.113 & 1.01 & 8.25 & 1.04 & 0.17 & 0.41 \\
\hline U243 & 53.5 & 0.808 & 15.2 & 9.05 & 0.141 & 6.42 & 9.42 & 1.94 & 1.04 & 0.112 & 0.99 & 8.14 & 1.13 & 0.09 & 0.42 \\
\hline
\end{tabular}

Group B shows higher values of the following trace elements: $\mathrm{Rb}, \mathrm{Ni}, \mathrm{Y}, \mathrm{Zn}$ and $\mathrm{V}$ and lower values of $\mathrm{Cr}$ with respect to Group $\mathrm{A}$. The other trace elements, $\mathrm{Nb}, \mathrm{Zr}, \mathrm{Sr}$, $\mathrm{Ba}$ and $\mathrm{Ga}$, show a similar distribution between both groups.

In both groups, a different geochemical signature in the two dike zones considered can be recognized. Regarding the major elements, Zone 2 represents an enrichment of the following elements in Groups $\mathrm{A}$ and $\mathrm{B}$ : $\mathrm{TiO}_{2}, \mathrm{Na}_{2} \mathrm{O}, \mathrm{K}_{2} \mathrm{O}$ and $\mathrm{P}_{2} \mathrm{O}_{5}$, and $\mathrm{a}$ decrease of $\mathrm{SiO}_{2}, \mathrm{MgO}$ and $\mathrm{CaO}$. For some other major elements a different 
behavior can be observed. In Group $\mathrm{A}$ an enrichment of $\mathrm{FeO}_{\mathrm{t}}$ and $\mathrm{MnO}$ and a decrease in $\mathrm{Al}_{2} \mathrm{O}_{3}$ is observable, when compared Zone 2 to Zone 3. In the Group $\mathrm{B}$ the opposite behavior occurs.

Table 2.3: Trace elements compositions of the dolerites (in ppm).

\begin{tabular}{lccccccccccc}
\hline Sample & $\mathbf{C r}$ & $\mathbf{N i}$ & $\mathbf{R b}$ & $\mathbf{N b}$ & $\mathbf{Z r}$ & $\mathbf{Y}$ & $\mathbf{S r}$ & $\mathbf{B a}$ & $\mathbf{Z n}$ & $\mathbf{G a}$ & $\mathbf{V}$ \\
\hline Group A & & & & & & & & & & & \\
U8M1 & 136 & 107 & 24 & 8 & 115 & 20 & 194 & 386 & 76 & 16 & 211 \\
U8P7 & 22 & 29 & 39 & 10 & 203 & 37 & 198 & 478 & 128 & 22 & 328 \\
U11A & 54 & 31 & 52 & 11 & 212 & 37 & 207 & 485 & 115 & 20 & 381 \\
U110 & 25 & 25 & 47 & 10 & 195 & 34 & 211 & 453 & 132 & 21 & 404 \\
U11M1 & 41 & 44 & 35 & 10 & 180 & 34 & 195 & 403 & 124 & 20 & 437 \\
U11M12 & 54 & 33 & 50 & 10 & 215 & 36 & 214 & 482 & 118 & 21 & 373 \\
U12A & 135 & 103 & 15 & 6 & 112 & 20 & 189 & 270 & 74 & 20 & 206 \\
U12B & 175 & 115 & 16 & 6 & 106 & 16 & 187 & 275 & 72 & 16 & 201 \\
U55M1 & 140 & 109 & 30 & 7 & 115 & 22 & 195 & 355 & 80 & 19 & 208 \\
U55M4 & 77 & 106 & 21 & 4 & 126 & 22 & 212 & 661 & 84 & 18 & 222 \\
U56 & 49 & 30 & 44 & 13 & 204 & 36 & 214 & 483 & 118 & 19 & 368 \\
U59 & 54 & 32 & 49 & 12 & 224 & 37 & 235 & 817 & 98 & 21 & 398 \\
U62M3 & 28 & 33 & 45 & 10 & 192 & 32 & 199 & 463 & 125 & 20 & 404 \\
U62M6 & 82 & 107 & 25 & 6 & 125 & 24 & 196 & 307 & 85 & 18 & 220 \\
U64M1 & 51 & 30 & 47 & 12 & 209 & 39 & 283 & 1732 & 102 & 21 & 385 \\
U64M2 & 100 & 63 & 33 & 11 & 244 & 44 & 146 & 339 & 147 & 21 & 377 \\
U215M1 & 28 & 31 & 33 & 6 & 194 & 33 & 201 & 447 & 127 & 20 & 440 \\
U215M3 & 81 & 111 & 33 & 7 & 116 & 21 & 193 & 283 & 84 & 19 & 227 \\
Group B & & & & & & & & & & & \\
U13M1 & 32 & 47 & 30 & 10 & 194 & 40 & 176 & 409 & 130 & 21 & 440 \\
U13M10 & 25 & 31 & 41 & 10 & 193 & 36 & 200 & 451 & 125 & 22 & 411 \\
U58M1 & 147 & 110 & 18 & 8 & 111 & 17 & 191 & 282 & 77 & 16 & 203 \\
U58M3 & 139 & 109 & 66 & 6 & 119 & 18 & 235 & 528 & 52 & 18 & 213 \\
U61 & 81 & 54 & 37 & 13 & 267 & 46 & 155 & 373 & 136 & 20 & 348 \\
U66P1 & 26 & 27 & 45 & 9 & 187 & 35 & 205 & 451 & 127 & 21 & 414 \\
U66P12 & 22 & 20 & 52 & 12 & 211 & 39 & 214 & 516 & 121 & 22 & 323 \\
U199 & 30 & 49 & 33 & 8 & 192 & 35 & 174 & 393 & 129 & 20 & 429 \\
U243 & 25 & 25 & 43 & 11 & 206 & 34 & 253 & 1117 & 118 & 19 & 392 \\
\hline & & & & & & & & & & &
\end{tabular}

Trace elements are distributed as follows: there is an enrichment of $\mathrm{Rb}, \mathrm{Nb}, \mathrm{Zr}$ and $\mathrm{Ba}$ in Zone 3 of both dike groups, whereas only Group A presents an enrichment of $\mathrm{Sr}$ and $\mathrm{Ga}$ in this zone. $\mathrm{Cr}, \mathrm{Ni}$ and $\mathrm{Zn}$ behave differently between both groups, where enrichment occurs in Zone 2 of Group $A$ and a decrease is observable in the same zone of Group B. Y and V also show a different behavior between both groups, with an enrichment of these elements in Zone 2 of Group B, and a decrease in Group A. Different geochemical signatures between both groups can be explained by various stages in the magmatic evolution within a tholeiitic series, with Group A being more evolved than Group B (Fig. 2.12). 
$\mathrm{TiO}_{2}$

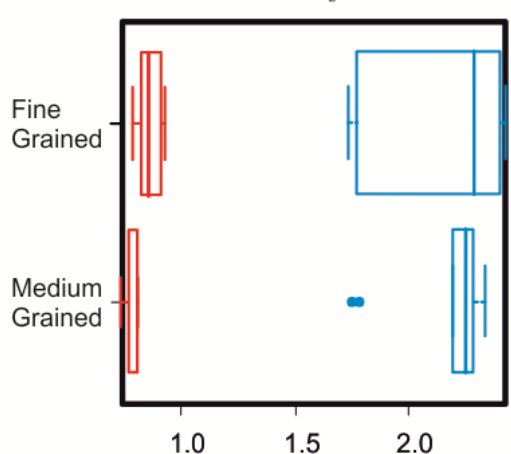

$\mathrm{MgO}$

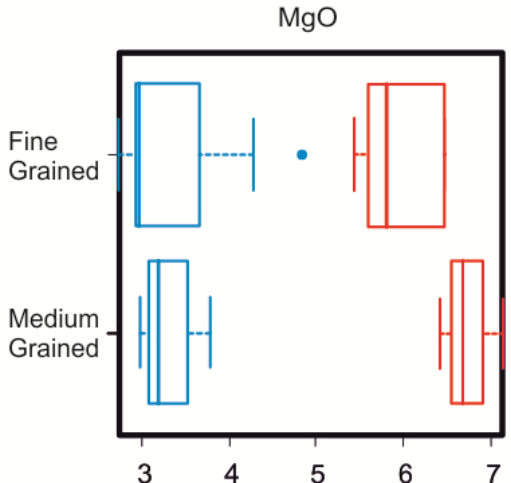

$\mathrm{Al}_{2} \mathrm{O}_{3}$
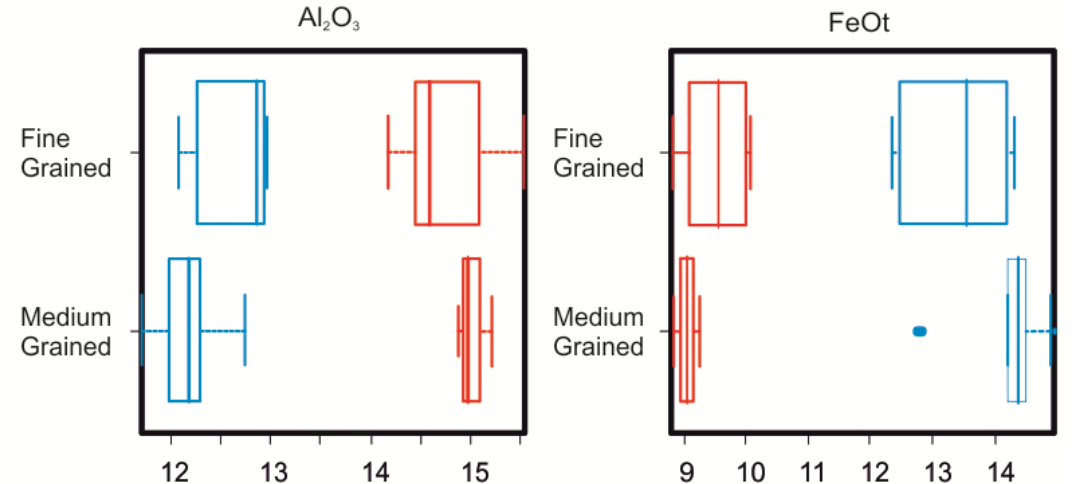

$\mathrm{Na}_{2} \mathrm{O}$
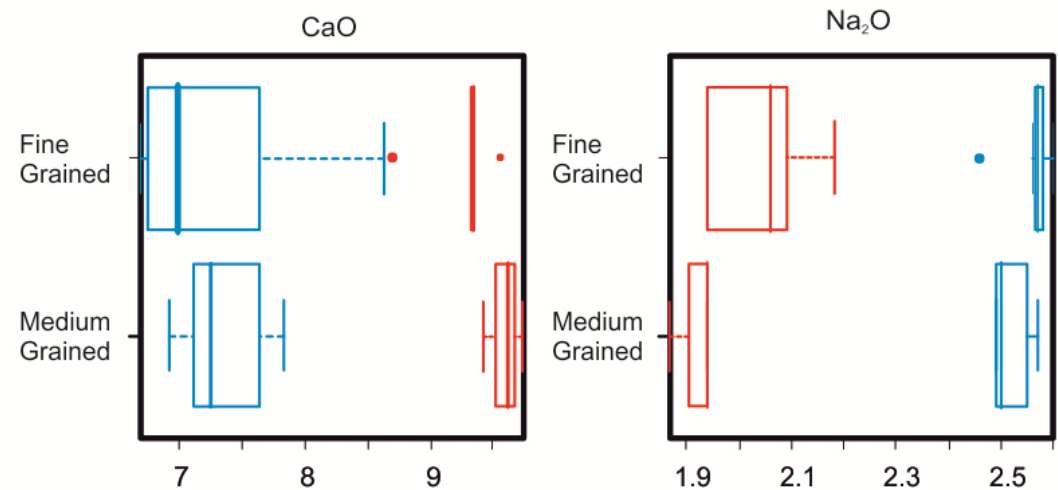

Fig. 2.11: Box plots of major elements in Groups $A\left(\mathrm{High} \mathrm{TiO}_{2}\right)$ and $\mathrm{B}\left(\mathrm{Low} \mathrm{TiO}_{2}\right)$ (in wt\%) by taking into account the grain size. Group A is blue and Group B is red. Bold line: median; box: Q1 - Q3 range; whiskers: standard deviation above and below the mean of the data; filled circles: outliers.

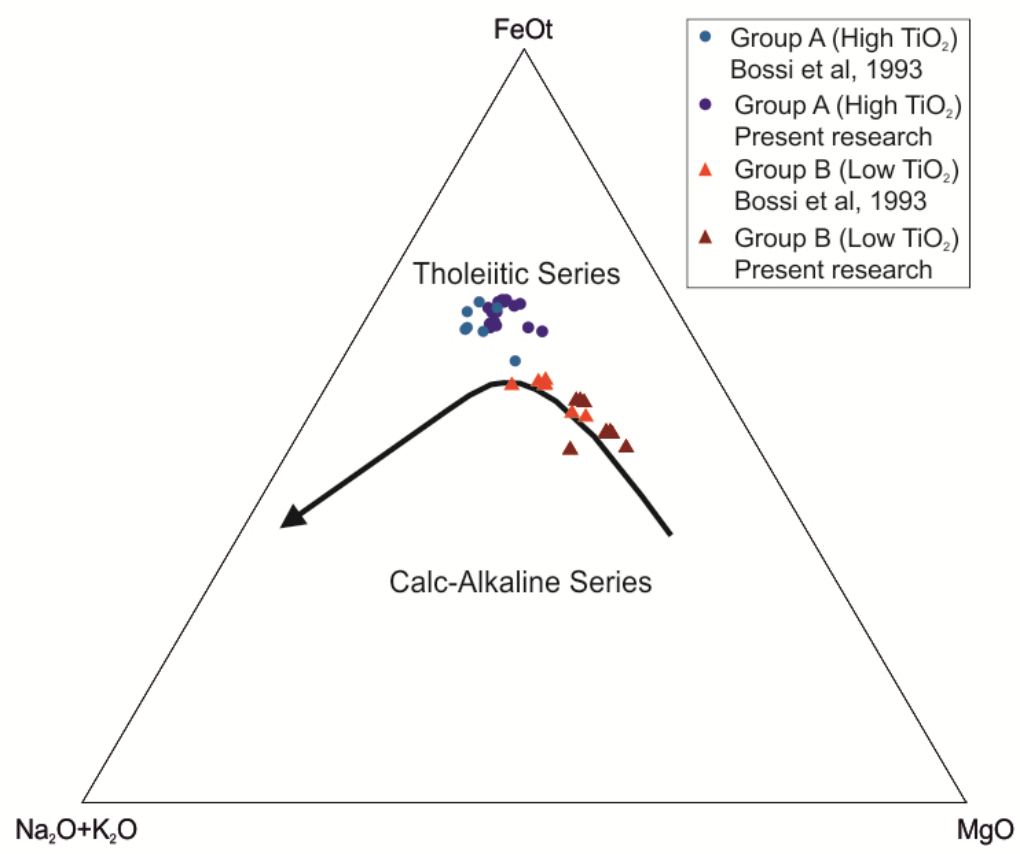

Fig. 2.12: AFM diagram showing the distribution of the dikes (data after Bossi et al, 1993 and this research). 


\subsubsection{Petrography}

Bossi and Campal (1991) described the petrography of the dike swarm based on the differences correlated with the two geochemical groups in the dikes. According to these authors, the main petrographical differences between both groups are mineralogical, where the high $\mathrm{TiO}_{2}$ rocks (Group A) show lower plagioclase contents. The plagioclase is of andesine composition in Group $\mathrm{A}$ and in low $\mathrm{TiO}_{2}$ rocks (Group B) plagioclase shows labradoritic composition.

The clinopyroxene present in both groups is augite, but in Group B orthopyroxene (broncite) can also occur. Bossi et al (1993) determined the composition of the clinopyroxenes as augite to subcalcic augite and pigeonite with high Ca contents. In Group A more opaques occur consisting of magnetite and ilmenite intergrowths, which are normally automorph crystals associated with pyroxene. Only small proportions of pyrite and chalcopyrite are present. In Group B the most important opaque mineral is skeletal ilmenite, which is associated with quartz-feldspar intergrowths and sometimes with pyroxene. Amphibole is present as a product of uralitization of clinopyroxene and is more common in Group A.

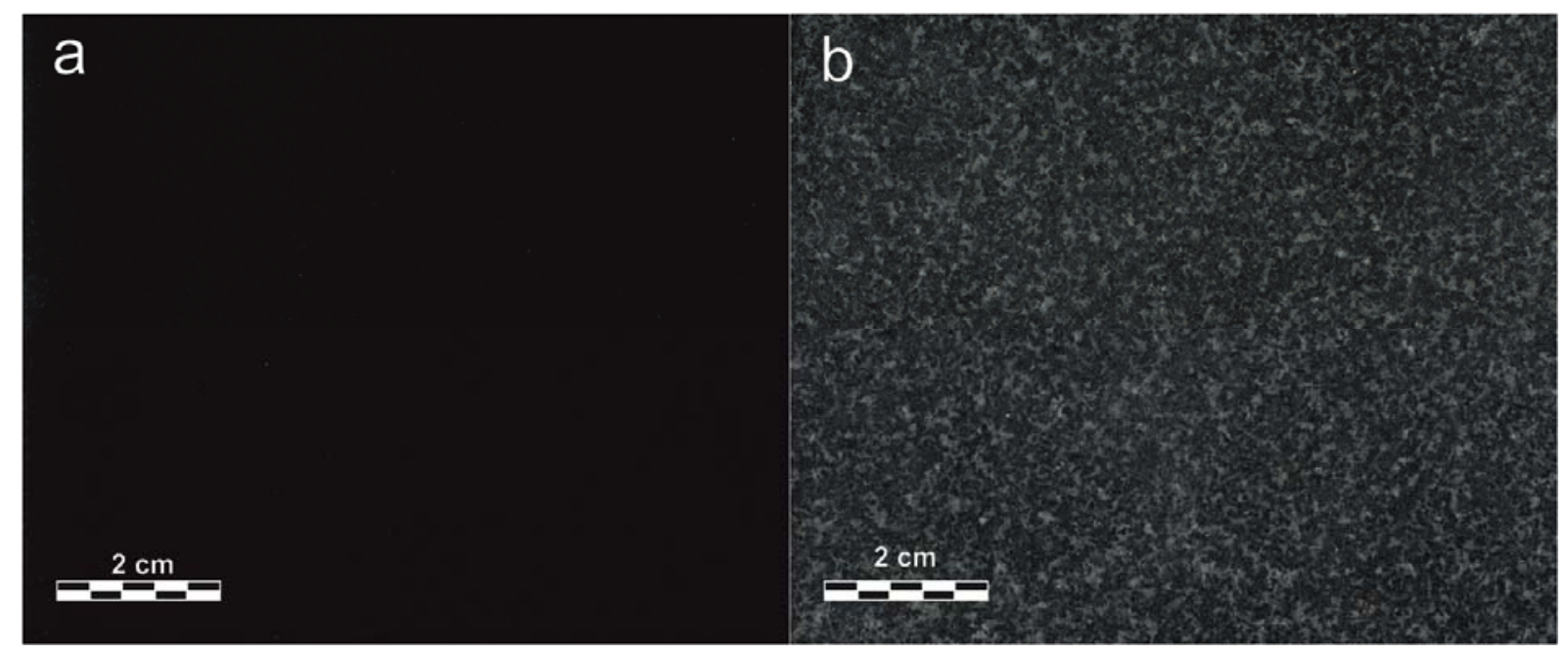

Fig. 2.13: a. Absolute Black dolerite; b. Moderate Black dolerite.

The term "micropegmatite" is used to refer to quartz intergrowths, normally composed of quartz and alkali feldspar, but sometimes also composed of quartz and plagioclase. These intergrowths are much more abundant in Group A, where they are composed of quartz and oligoclase. When apatite occurs, it is always related to these 
intergrowths. According to Bossi and Campal (1991), the grain size between 0.1 and $0.2 \mathrm{~mm}$ of the plagioclase laths characterizes the "Granito Negro Absoluto (Fig. 2.13a). "Granito Negro Fino" (0.3 and $0.5 \mathrm{~mm}$ ), "Granito Negro Oriental" (0.6 and 0.8 $\mathrm{mm}$ ) (Fig. 2.13b) and "Granito Negro Grueso" (plagioclase laths $>1 \mathrm{~mm}$ ) all show larger grain sizes.

Table 2.4: Petrographical data (modified after Bossi and Campal, 1991). Mineral abbreviation after Kretz (1983): An anortitie, Aug augite, Pl plagioclase

\begin{tabular}{|c|c|c|}
\hline $\begin{array}{l}\text { Geochemical } \\
\text { Classification }\end{array}$ & $\begin{array}{c}\text { Group A, high } \mathrm{TiO}_{2} \text { content (between } 1.5 \text { and } \\
2.5 \% \text { ). Andesi-basalt }\end{array}$ & $\begin{array}{c}\left.\text { Group B, low } \mathrm{TiO}_{2} \text { content (less than } 1.2 \%\right) . \\
\text { Basalt }\end{array}$ \\
\hline Plagioclase & $\begin{array}{l}\text { between } \mathrm{An}_{33} \text { and } \mathrm{An}_{44} \text {. Up to } 40 \% \text {, no } \\
\text { significant differences between both zones }\end{array}$ & $\begin{array}{c}\text { between } \mathrm{An}_{47} \text { and } \mathrm{An}_{60} \text {. Up to } 48 \% \text { in zone } 2 \\
\text { and } 44 \% \text { in zone } 3\end{array}$ \\
\hline Clinopyroxene & $\begin{array}{l}\text { mostly Aug, some pigeonite can be present, } \\
\text { up to } 25 \% \text {, no significant differences between } \\
\text { both zones }\end{array}$ & $\begin{array}{l}\text { mostly Aug, some pigeonite can occur, up to } \\
40 \% \text {, no significant differences between both } \\
\text { zones }\end{array}$ \\
\hline $\begin{array}{l}\text { Granophyric } \\
\text { intergrowth }\end{array}$ & around $10 \%$ in Zone 2 and $20 \%$ in Zone 3 & around $2 \%$ in Zone 2 and $10 \%$ in Zone 3 \\
\hline Amphibole & $\begin{array}{l}\text { hornblende as uralitization product of } \\
\text { clinopyroxene, up to } 13 \% \text { in Zone } 2 \text { and } 7 \% \\
\text { in Zone } 3\end{array}$ & $\begin{array}{l}\text { hornblende as uralitization product of } \\
\text { clinopyroxene, up to } 4 \% \text { in Zone } 2 \text { and } 6 \% \text { in } \\
\text { Zone } 3\end{array}$ \\
\hline Opaques & $\begin{array}{l}\text { magnetite in euhedral to subhedral crystals, } \\
\text { ilmenite in skeletal crystals, up to } 8 \% \text {, no } \\
\text { significant differences between both zones }\end{array}$ & ilmenite in elongated crystals, up to $2 \%$ \\
\hline Apatite & $\begin{array}{l}\text { always present in granophyric intergrowth and } \\
\text { as inclusions in } \mathrm{Pl}\end{array}$ & $\begin{array}{l}\text { always present in granophyric intergrowth and } \\
\text { as inclusions in } \mathrm{PI}\end{array}$ \\
\hline Biotite & $\begin{array}{l}\text { as accessory associated with clinopyroxenes } \\
\text { and opaques }\end{array}$ & $\begin{array}{c}\text { as accessory associated with clinopyroxenes } \\
\text { and opaques }\end{array}$ \\
\hline Texture & $\begin{array}{l}\text { subophitic, occasionally porphyritic in Zones } 1 \\
\text { and 2, phenocrystals of Pl and Aug }\end{array}$ & $\begin{array}{l}\text { subophitic, frequently porphyritic in Zones } 1 \\
\text { and 2, phenocrystals of Pl and Aug }\end{array}$ \\
\hline Grain Size $(\mathrm{Pg})$ & $\begin{array}{l}\text { between } 0.5 \text { and } 1 \mathrm{~mm} \text { in Zone 2, and } \\
\text { between } 1 \text { and } 2 \mathrm{~mm} \text { in Zone } 3\end{array}$ & $\begin{array}{l}\text { between } 0.5 \text { and } 1 \mathrm{~mm} \text { in Zone } 2 \text {, and } \\
\text { between } 1.5 \text { and } 2 \mathrm{~mm} \text { in Zone } 3\end{array}$ \\
\hline
\end{tabular}

Spoturno et al (2004) have also studied these rocks but did not differentiate them into two groups. They described the rocks as being composed of plagioclase with grain sizes around $0.3 \mathrm{~mm}$, when measured parallel to the long axis (approximate composition: labradorite) and pyroxene, i.e., augite, pigeonite and occasionally orthopyroxene. Occasionally, microphenocrysts of plagioclase and augite have been 
Case study: Dolerites

observed with sizes up to $2 \mathrm{~mm}$ giving the rock a microporphiritic texture. Accessories include ilmenite with leucoxene rims and apatite. These authors also described the presence of amphibole of uralitic origin, a product of alteration of pyroxene.

The petrographical observations corroborate the previous research, with new information being added by this study. In Table 2.4 the main observations are summarized and the petrographic details are shown in Figures 2.14 to 2.18.

Using the Michel-Levy method, the plagioclase laths in Group A were determined to have an $\mathrm{An}_{34}-\mathrm{An} 44$ composition (andesine), whereas Group $B$ shows an $A n_{47}-A n_{60}$ composition (labradorite). In both groups plagioclase occurs as fine-grained euhedrally zoned laths (for grain sizes see Table 2.1 and Figures 2.7 and 2.8). In Group A the laths commonly contain inclusions of very fine-grained apatite crystals.

The clinopyroxene is generally augite, but also some pigeonite can be observed. The augite in Group A occurs as small crystals with grain sizes between 0.4 and $0.6 \mathrm{~mm}$. They are euhedral to subhedral, very often exhibit twining and are surrounded by amphibole and to a lesser extent by biotite. In Group B the augites are coarser grained, with sizes ranging between 0.4 and $2.4 \mathrm{~mm}$. The crystals are euhedral to subhedral and generally show an aspect ratio up to four. Very often they show twining and are sometimes surrounded by amphibole and biotite.

Biotite is present as euhedral to subhedral crystals with sizes up to $0.9 \mathrm{~mm}$ (with an aspect ratio of 4.5 ) in Group A. In Group B the grain size only reaches $0.2 \mathrm{~mm}$ with an aspect ratio of 2 . In both groups it occurs as an accessory. The biotite present is always related to magnetite or augite. 


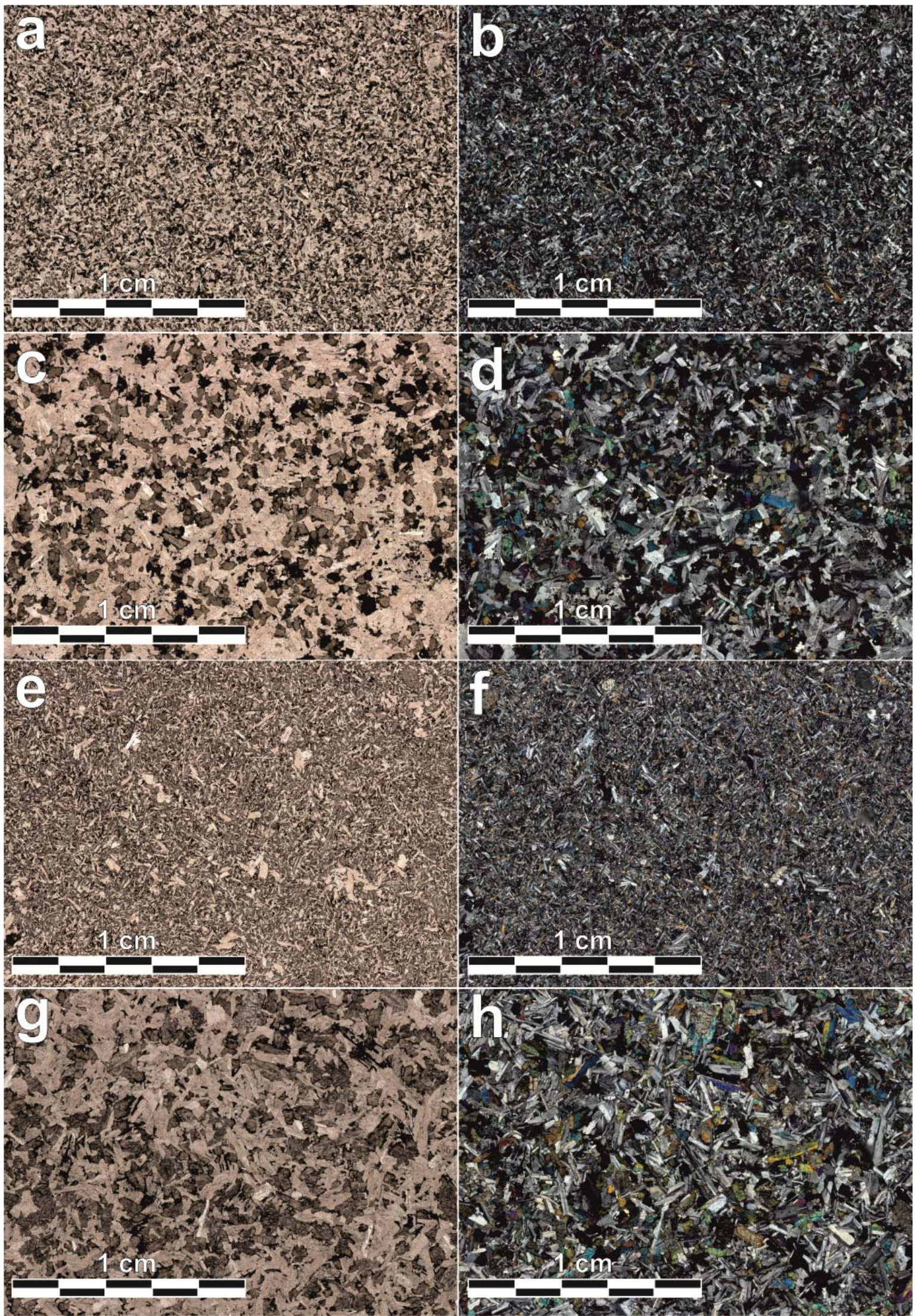

Fig. 2.14: General overview of the Uruguayan dolerite fabrics: $\mathbf{a}$. and b. Zone 2 in dike from Group A;

c. and d. Zone 3 in dike from Group A; e. and f. Zone 2 in dike from Group B; g. and h. Zone 3 in dike from Group B.(Left column: plane polarized light; right column: crossed polarized light). 
All samples exhibit the presence of granophyric intergrowth as described by Shelley (1993), which Bossi and Campal (1991) and Spoturno et al (2004) refer to as "micropegmatite" or interstitial quartz-feldspar intergrowths. In some cases microcline can be recognized within the granophyric intergrowth, but in other thin sections it is difficult to determine the nature of the feldspar present. They are normally up to 0.8 $\mathrm{mm}$ in size in Group A, but up to $1.6 \mathrm{~mm}$ in some cases and smaller in Group B, up to $0.6 \mathrm{~mm}$.

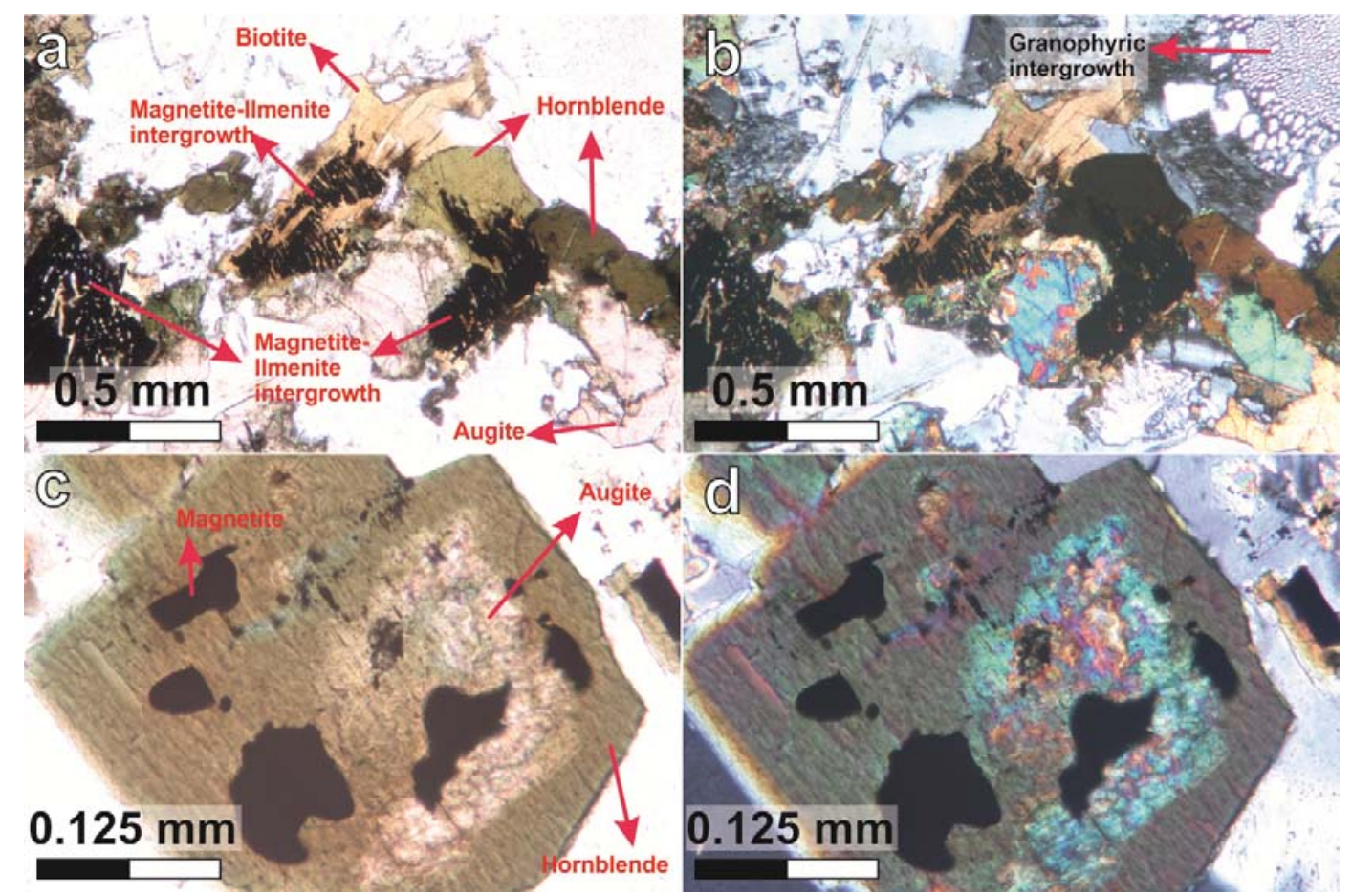

Fig. 2.15: Texture and mineralogy of Zone 3 in dike from Group A: a. Biotite crystals surrounding magnetite-ilmenite and hornblende crystals partially surrounding augite and magnetite-ilmenite crystals (plane polarized light, width of view $1.8 \mathrm{~mm}$ ); b. Same image as in a. but in crossed polarized light; c. Augite crystal almost totally replaced by hornblende with inclusions of opaque minerals (plane polarized light, width of view $0.45 \mathrm{~mm}$ ); $\mathbf{d}$. Same image as in c. but in crossed polarized light.

Opaques are also present as accessory minerals and are much more frequent in Group A, where magnetite crystals are euhedral to anhedral and the ilmenite crystals are skeletal. Both crystals always occur with augite and biotite as intergrowths, never surrounded by plagioclase. Their size is between 0.2 and $0.8 \mathrm{~mm}$. In Group B the opaques are skeletal, long and lath-shaped ilmenite up to $0.7 \mathrm{~mm}$ with an aspect ratio up to 14 . The very fine-grained magnetite crystals are subhedral to anhedral with a size up to $0.3 \mathrm{~mm}$. Both are often distributed around augite as well as around 
the plagioclase. The opaques are homogeneously distributed in the grain size zones (1, 2 and 3), and in Zones 1 and 2 their grain size is generally smaller than the plagioclase laths. In Group B the opaques are sometimes surrounded by red spots of limonite or hematite.

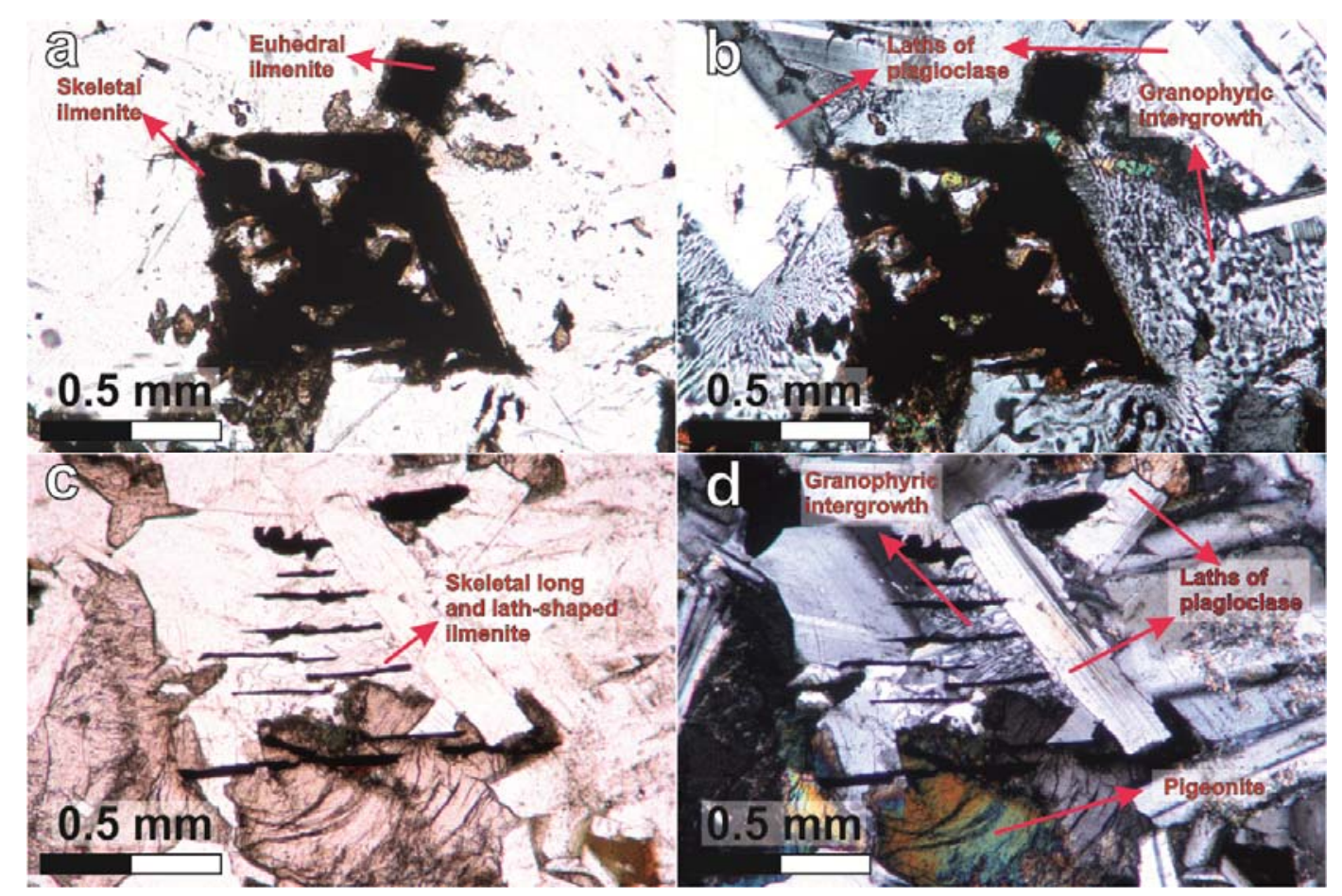

Fig. 2.16: a. Skeletal and euhedral ilmenite, dike of Group A, Zone 3 (plane polarized light, width of view $1.8 \mathrm{~mm}$ ); b. Laths of plagioclase and granophyric intergrowth (same image as in a. but in crossed polarized light); c. Skeletal, long and lath-shaped ilmenite. Group B dike, Zone 3 (plane polarized light, width of view $1.8 \mathrm{~mm}$ ); $\mathbf{d}$. Laths of plagioclase and crystals of pigeonite with typically curved fractures (same image as in c. but in crossed polarized light).

Apatite is found as an accessory, as very small (up to $0.1 \mathrm{~mm}$ in length) euhedral crystals with basal hexagonal sections and needle-like longitudinal sections. They are always included in the granophyric intergrowth and can be very often found as inclusions in the plagioclase of Group A.

Hornblende occurs as a product of uralitization of clinopyroxenes, where they appear either with fibrous habit or as euhedral to subhedral crystals with sizes up to $0.4 \mathrm{~mm}$. They are more frequent in Group A. 


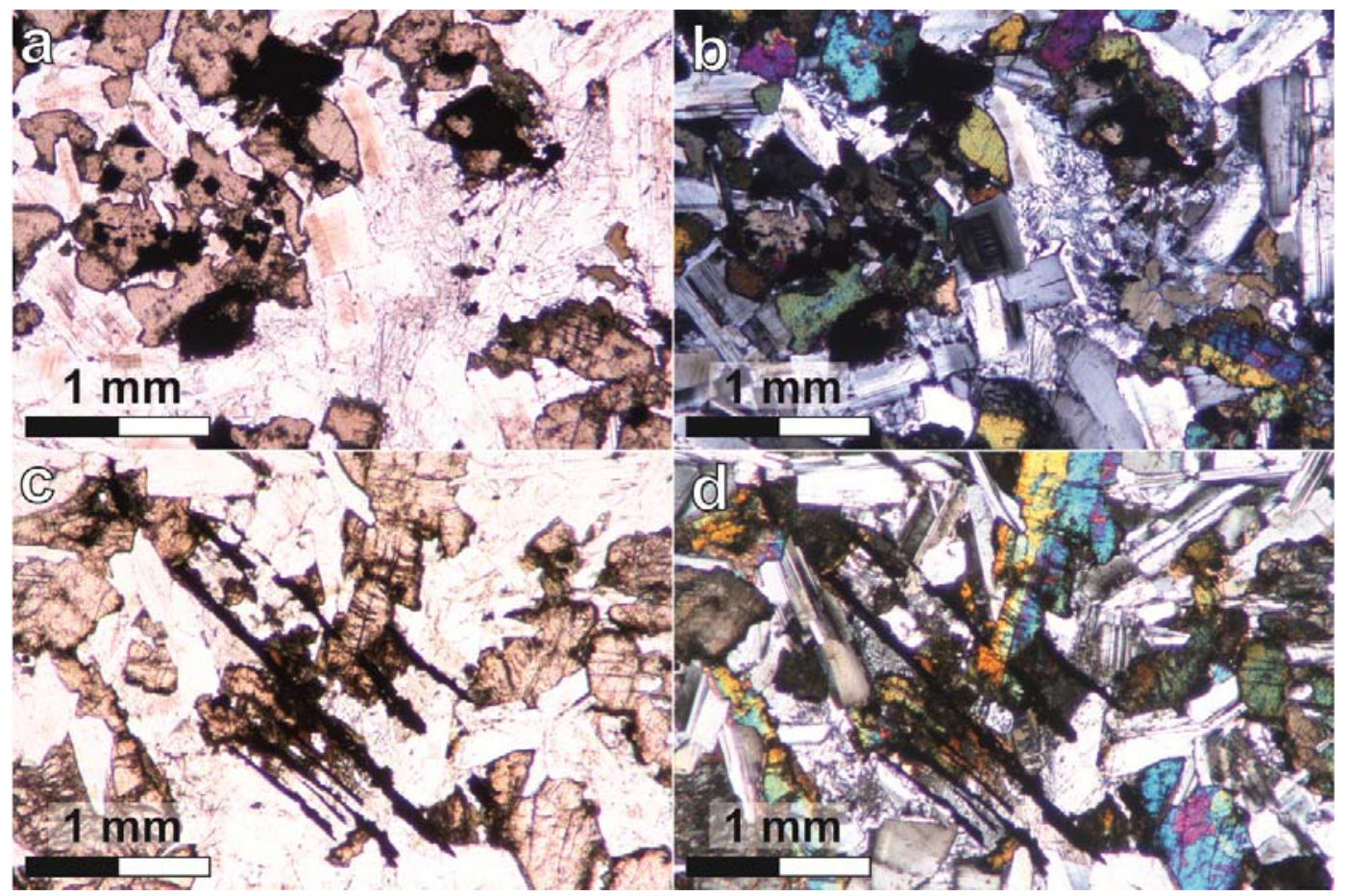

Fig. 2.17: a. Subophitic texture in dike of Group A, Zone 3 in plane polarized light (PPL), width of view $3.6 \mathrm{~mm}$; b. Same image as in a. but in crossed polarized light (CPL); c. Subophitic texture in dike of Group B, Zone 3 (PPL, width of view $3.6 \mathrm{~mm}$ ); d. Same image as in c. but in CPL.

Calcite only occurs as an accessory in a dike from Group B in Zone 3 (sample U13). It appears as very fine-grained (up to $0.2 \mathrm{~mm}$ ) anhedral to subhedral crystals normally associated with biotite.

The texture normally observed in both groups is subophitic, but there are some local variations. A porphyritic texture is observed in the chilled margins of two dikes from Group B and in one from Group A. In the dike from Group A the phenocrysts are plagioclase (sample U55) and in the dikes from Group B they are plagioclase and augite. In one sample (U13) they are altered to calcite and chlorite, respectively.

In both dolerite groups the normative mineral compositions show more or less comparable values (see Table 2.5). The $\mathrm{M}$ value (color index: total volume percent of mafic minerals) varies between 29 and $37 \%$ in Group A and between 31 and $34 \%$ in Group B.

For both groups the normative $\mathrm{M}$ values are comparable between Zone 2 and Zone 3. For Group A, Zone 2 has a value of 31 and Zone 3 a value of $33 \%$. In Group B 
Case study: Dolerites

both zones have an $M$ value of $33 \%$. Only one sample of Group A shows an important difference: $37 \%$ in Zone 2 and 33\% in Zone 3 (Quarry U55). Evenso, M values for zones 2 and 3 are comparable, the Absolute Black (Zone 2) appears much darker than the Moderate Black (Zone 3) due to the smaller grain size.

Table 2.5: Normative minerals distribution in both groups (in wt\%).

\begin{tabular}{|c|c|c|c|c|c|c|c|c|c|c|c|}
\hline Sample & $\mathbf{Q}$ & Ort & $\mathbf{A b}$ & An & Hy & Di & Mag & $\mathrm{IIm}$ & Ap & Cc & \%An in $\mathrm{PI}$ \\
\hline \multicolumn{12}{|l|}{ Group A } \\
\hline U8M1 & 10.4 & 11.3 & 22.6 & 16.8 & 18.2 & 12.2 & 2.5 & 4.7 & 0.7 & 0.6 & 42.7 \\
\hline U8P7 & 8.9 & 9.7 & 21.7 & 17.3 & 19.9 & 14.3 & 2.7 & 4.4 & 0.6 & 0.5 & 44.4 \\
\hline U11A & 10.9 & 10.6 & 22.3 & 19.0 & 18.6 & 11.9 & 2.3 & 3.4 & 0.5 & 0.3 & 45.9 \\
\hline U110 & 8.3 & 9.9 & 22.2 & 17.3 & 19.4 & 14.8 & 2.7 & 4.5 & 0.6 & 0.2 & 43.7 \\
\hline U11M1 & 10.0 & 10.6 & 22.5 & 17.2 & 18.5 & 13.3 & 2.5 & 4.4 & 0.6 & 0.4 & 43.3 \\
\hline U11M12 & 8.8 & 9.8 & 21.8 & 17.2 & 19.9 & 14.5 & 2.7 & 4.4 & 0.6 & 0.4 & 44.2 \\
\hline U12A & 5.4 & 8.8 & 21.7 & 18.4 & 21.8 & 15.3 & 2.8 & 4.5 & 0.7 & 0.6 & 45.8 \\
\hline U12B & 5.2 & 8.9 & 21.8 & 18.5 & 21.9 & 15.2 & 2.8 & 4.5 & 0.7 & 0.5 & 46.0 \\
\hline U55M1 & 3.0 & 9.2 & 22.3 & 19.9 & 21.6 & 15.2 & 2.7 & 4.7 & 0.9 & 0.6 & 47.2 \\
\hline U55M4 & 10.0 & 9.9 & 21.7 & 16.5 & 19.9 & 13.7 & 2.7 & 4.3 & 0.6 & 0.7 & 43.2 \\
\hline U56 & 8.5 & 9.9 & 22.0 & 16.7 & 19.9 & 14.7 & 2.7 & 4.4 & 0.6 & 0.5 & 43.1 \\
\hline U59 & 1.6 & 8.3 & 21.4 & 20.8 & 23.0 & 16.1 & 2.7 & 4.6 & 0.8 & 0.6 & 49.3 \\
\hline U62M3 & 10.8 & 10.7 & 22.2 & 18.6 & 18.8 & 12.2 & 2.4 & 3.4 & 0.5 & 0.3 & 45.6 \\
\hline U62M6 & 10.8 & 10.8 & 22.3 & 18.4 & 18.9 & 11.9 & 2.4 & 3.5 & 0.5 & 0.5 & 45.2 \\
\hline U64M1 & 9.1 & 10.3 & 22.4 & 16.9 & 19.6 & 13.4 & 2.7 & 4.5 & 0.8 & 0.5 & 43.0 \\
\hline U64M2 & 7.3 & 9.0 & 21.8 & 18.4 & 20.7 & 14.7 & 2.7 & 4.3 & 0.6 & 0.6 & 45.8 \\
\hline U215M1 & 11.4 & 11.1 & 22.4 & 18.6 & 18.6 & 11.2 & 2.3 & 3.4 & 0.6 & 0.3 & 45.4 \\
\hline U215M3 & 11.6 & 11.2 & 22.3 & 18.7 & 18.4 & 11.1 & 2.3 & 3.5 & 0.5 & 0.3 & 45.6 \\
\hline Average & 8.4 & 10.0 & 22.1 & 18.1 & 19.9 & 13.6 & 2.6 & 4.2 & 0.6 & 0.5 & 45.0 \\
\hline \multicolumn{12}{|l|}{ Group B } \\
\hline U13M1 & 3.3 & 11.2 & 19.1 & 28.2 & 22.5 & 12.0 & 1.5 & 1.7 & 0.3 & 0.4 & 59.6 \\
\hline U13M10 & 6.3 & 5.9 & 16.7 & 29.6 & 24.1 & 13.3 & 1.5 & 1.6 & 0.3 & 0.8 & 63.9 \\
\hline U58M1 & 7.1 & 6.9 & 18.0 & 27.3 & 21.7 & 14.9 & 1.6 & 1.8 & 0.3 & 0.5 & 60.3 \\
\hline U58M3 & 7.9 & 6.5 & 17.7 & 26.9 & 22.1 & 14.5 & 1.6 & 1.7 & 0.3 & 0.8 & 60.4 \\
\hline U61 & 7.4 & 7.1 & 18.1 & 27.3 & 21.0 & 15.0 & 1.6 & 1.8 & 0.3 & 0.4 & 60.2 \\
\hline U66P1 & 7.4 & 5.8 & 16.8 & 29.1 & 22.8 & 14.4 & 1.5 & 1.5 & 0.3 & 0.4 & 63.4 \\
\hline U66P12 & 6.1 & 5.5 & 16.1 & 30.4 & 24.6 & 13.4 & 1.4 & 1.4 & 0.2 & 0.7 & 65.3 \\
\hline U199 & 6.7 & 6.3 & 16.8 & 30.0 & 23.7 & 12.7 & 1.5 & 1.6 & 0.3 & 0.4 & 64.2 \\
\hline U243 & 6.6 & 6.3 & 16.8 & 30.4 & 23.2 & 13.2 & 1.5 & 1.6 & 0.3 & 0.2 & 64.4 \\
\hline Average & 6.5 & 6.8 & 17.3 & 28.8 & 22.9 & 13.7 & 1.5 & 1.6 & 0.3 & 0.5 & 62.4 \\
\hline
\end{tabular}

This color index, which is determined by the normative mineral composition, shows some differences compared to the modal mineral composition. In Group A the modal mineral composition exhibits an $M$ value of $49 \%$ in Zone 2 and $38 \%$ in Zone 3. Group B shows $49 \%$ in Zone 2 and $47 \%$ in Zone 3 . All the samples have an $M$ value higher than $30 \%$, and therefore are classified as mesocratic. 


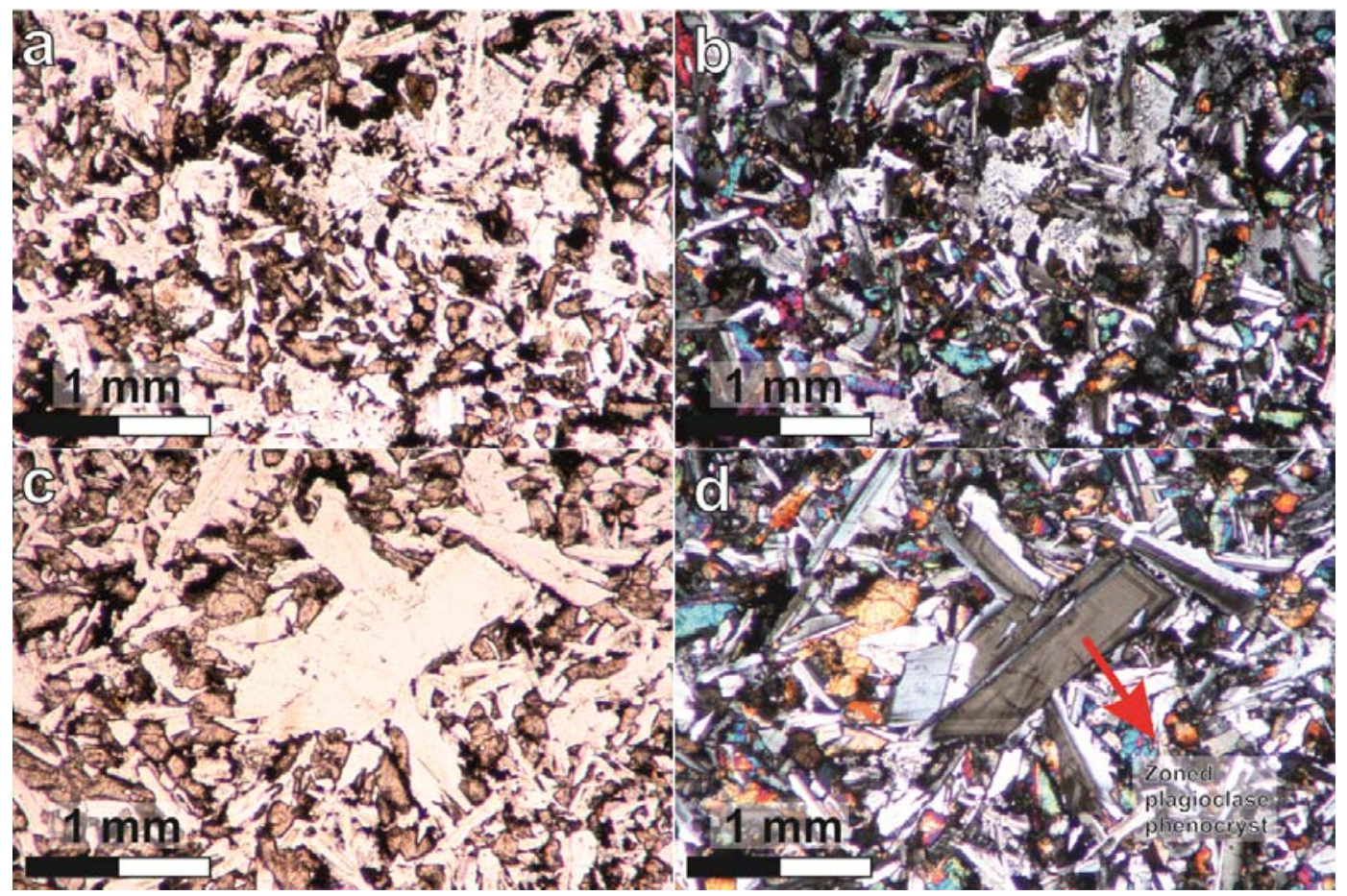

Fig. 2.18: a. Equigranular texture in dike of Group A, Zone 2, where a homogenous distribution of the opaques is visible in plane polarized light (PPL), width of view $3.6 \mathrm{~mm}$; b. Same image as in a. but in crossed polarized light (CPL); c. Porphyritic texture in dike of Group B, Zone 2. Several phenocrysts of plagioclase are visible (PPL, width of view $3.6 \mathrm{~mm}$ ); d. Same image as in c. but in CPL.

2.3.3. Determination of commercial varieties: influence of grain size, fabric, chemical and mineral composition

A first classification based on the color of the rock and grain size of plagioclase was made by Bossi and Campal (1991) and continued by Bossi and Schipilov (2007). They determined that the Absolute Black is aphanitic with a mean grain size between 0.1 and $0.2 \mathrm{~mm}$. Fine Black is a fine-grained variety with a grain size between 0.3 and $0.5 \mathrm{~mm}$. Normal Black (known as Oriental) has a grain size between 0.6 and 0.8 $\mathrm{mm}$ and the Coarse Black is coarser than $1 \mathrm{~mm}$.

The results and observations collected in the current investigation broadly agree with the above classification. However, a new one is proposed based on variations in grain size, measured on the $c$ axes of the plagioclase laths that are slightly different, and therefore the Uruguayan dolerites can be classified as follows: Absolute Black (Negro Absoluto), with aphanitic texture, grain size $<1 \mathrm{~mm}$, Moderate Black (Negro Oriental) with phaneritic texture, 1-2 $\mathrm{mm}$ and Special Black, which is similar to 
moderated black but with some heterogeneity in the color, for example: green or white spots due to the presence of large hornblende and plagioclase crystals, respectively.

The chemical composition influences the mineralogy, and therefore the décor of the rock. For both groups, rocks of Zone 2 are darker than those of Zone 3, caused by higher modal $\mathrm{M}$ values, but also by their smaller grain size, as the mafic minerals are better distributed in the whole rock.

\subsubsection{Color measurements}

The black and dark gray color characterizes the dolerites mined in Uruguay. These colors are determined by a relatively high proportion of mafic minerals (e.g. pyroxenes, amphiboles, opaque minerals) and by the occurrence of clear plagioclase. Absolute Black Dolerite shows a deep black color that is very homogeneous due to the lack of veins and its very fine-grained texture. Moderate Black Dolerite, also commercialized as Sacramento or Oriental Granite, has a dark gray color, which is sometimes interrupted by white spots due to the presence of larger granophyric intergrowths. Light gray aplitic veins up to five centimeter in thickness are sometimes observable, but these can be easily avoided during the mining process.

Color measurements were performed at the Labor für Baudenkmalpflege in Naumburg (Germany) on 12 different black dimensional stones. In Figure 2.19 all results are listed. The $L^{*}$ values, which determines the brightness, ranged from 25.22 for the Absolute Black dolerite to 42.47 for the Kvemo quartz-phyllite. a* values are between -0.03 for the Impala gabbro/norite and 1.00 for the Galaxy Brazil. b* values range between -0.13 for Kvemo and 1.60 for Impala (Fig. 2.19).

Motoki and Zucco (2005) developed a classification that takes into account the B parameter (brightness) from the HSB color system. The category limits determined by these authors have been converted to the CIE Lab color system as follows: black $(L<27)$, dark gray $(27<L<58)$, light gray $(58<L<87)$, and white $(L>87)$. Utilizing this 
classification, the Absolute Black dolerite can be defined as black and the Moderate Black dolerite as dark gray.

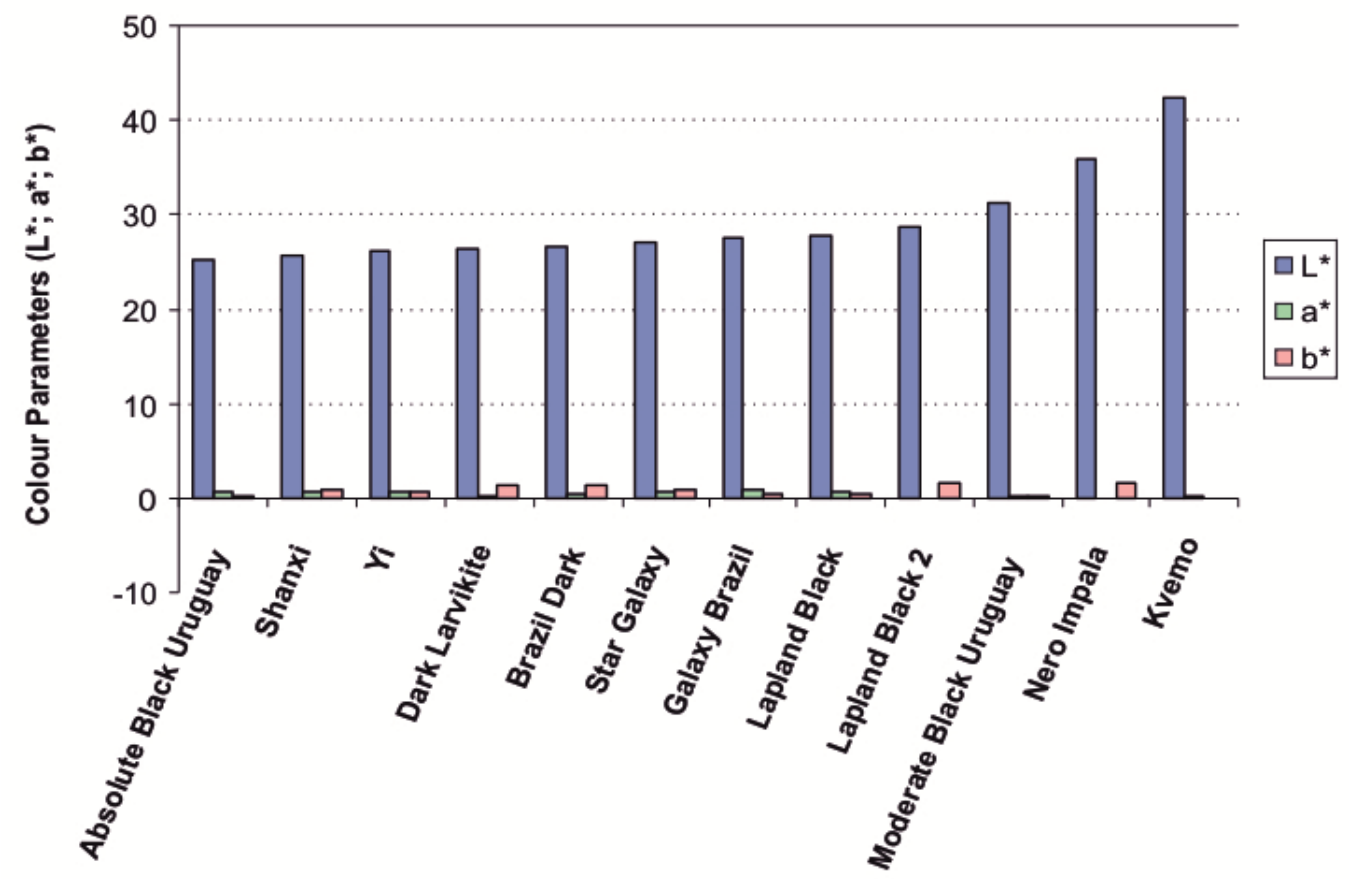

Fig. 2.19: Color measurements for various black dimensional stones.

The field observations made in the current investigation support most of the conclusions of the previously mentioned authors. They are:

1. The dikes are parallel to each other and strike ENE. The length of each dike is usually greater than 1,000 meters. In the area of Polonia-Pichinango four quarries are located within the same dike (Fig. 2.4). Some dikes may have a greater extension as is presently assumed.

2. According to Bossi and Campal (1991), the widths of the dikes range from 0.5 to 80 meters, being in average $20 \mathrm{~m}$. In this investigation the width of the dikes, where a quarry is located, were determined to be between 19 and 41 meters.

3. The contacts with the country rock are usually plane and parallel, sub-vertical and dip steeply towards the southeast.

4. The dikes crop out in different ways and not all along their projected paths. Sometimes large boulders crop out; similar to those of granitic rocks (Fig. 2.21a). In numerous cases the dolerites are poorly exposed and usually very fractured (Fig. 2.21b). 
5. There is no preferred topographical outcrop position. The dikes are found at the top and in the middle of hills but also at the same contour level as streams.

\subsection{Occurrences and deposits}

2.4.1. Regional distribution: length, width, frequency, country rock relations

The two groups investigated from the dike swarm intruded into an area of $20,000 \mathrm{~km}^{2}$ and in all the lithologies of the Piedra Alta Terrane, which consists of granites, metagranites and metasediments (Figure 2.20). Bossi et al (1993) pointed out that Group A crops out more often in the northern part of the Piedra Alta Terrane and Group B more to the southern part.

The dikes and the quarrying were first mentioned in Bossi (1969). All the mining concessions and 15 locations where the dikes were mined, were mentioned in an internal report of the DINAMIGE (National Geological Survey of Uruguay; Medina and Carrión, 1986). In 1987, Medina and Carrión presented another report that described just the dikes affected by exploration and the mining permissions obtain from the Florida Department.

Bossi et al (1989) presented the first photogeological map where the distribution of the dikes is shown. The map depicts thousands of parallel dikes intruding the "ancient orogenic cycle" or what it is now known as the Piedra Alta Terrane (PAT). The dikes follow a NE-E direction, but in the eastern margin of the terrane, near the Sarandí del Yí Shear Zone, they change direction to S-SE, due to the dextral shear activities during the Proterozoic. They were recognized using aerial photographs at 1:20,000 scale and corroborated with field observations (Bossi and Campal, 1991). Since this map is based on photographic aerial surveys, it was impossible to verify the presence of all these dikes in the field, and therefore the number of dikes is probably smaller than originally proposed.

More recently, Spoturno et al (2004) published a geological and mineral resources map for the San José Department at a scale of 1:100,000. This represents an area of almost $5,000 \mathrm{~km}^{2}$, which corresponds to approximately the half of the area to where 
the Piedra Alta Terrane crops out. They recognized a total of eleven dikes; six of them have been mined in the past for the extraction of dolerite blocks for the dimensional stone market. Techera et al (2004) studied in detail the different quarries present in the San José Department and their observations are in accordance with those of Bossi and Campal (1991) and Bossi and Ferrando (2001).

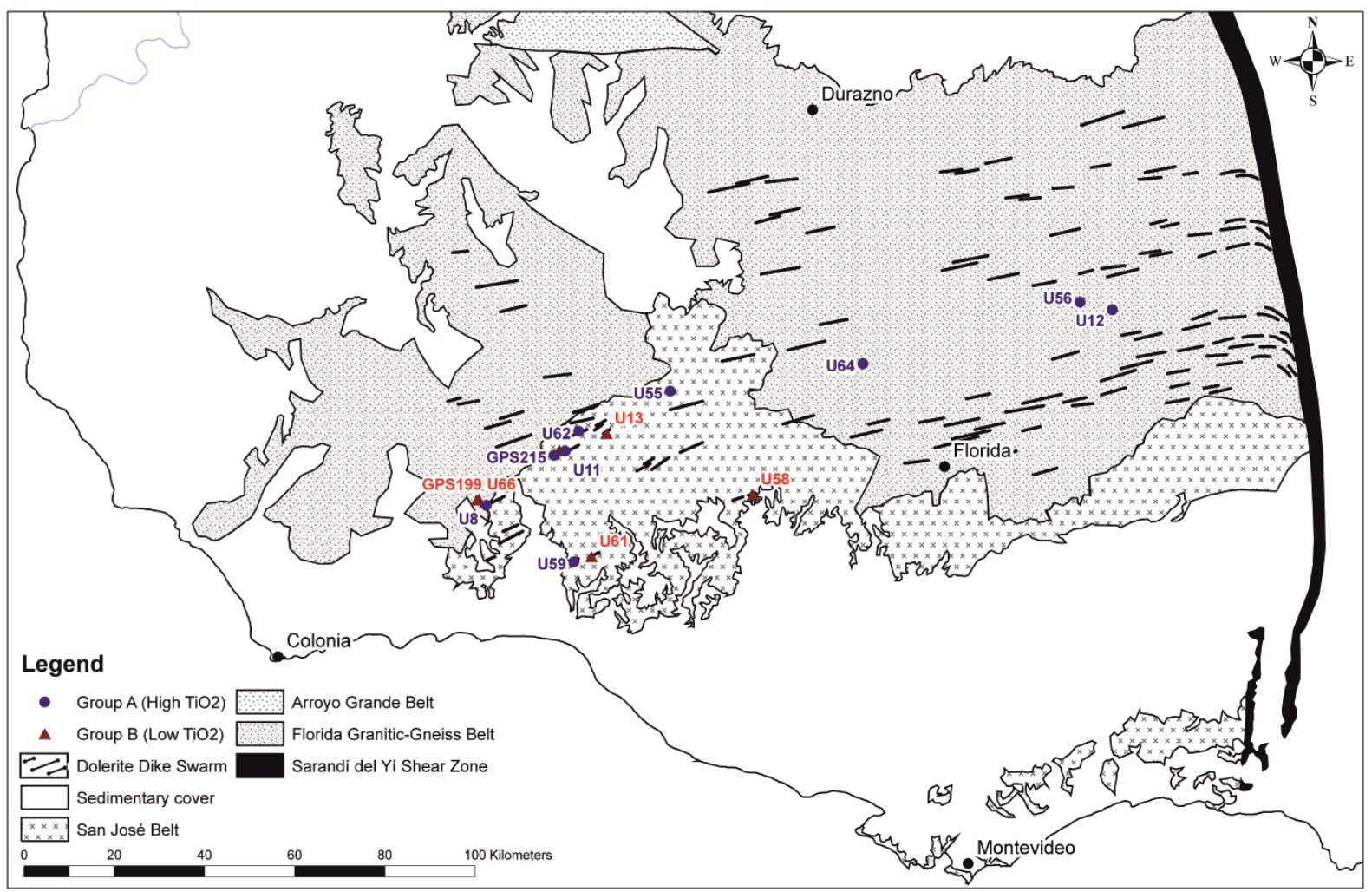

Fig. 2.20: Geological map with sampled quarries (map redrawn after Bossi and Ferrando, 2001).

A summary of the dikes sampled are listed in Table 2.6.

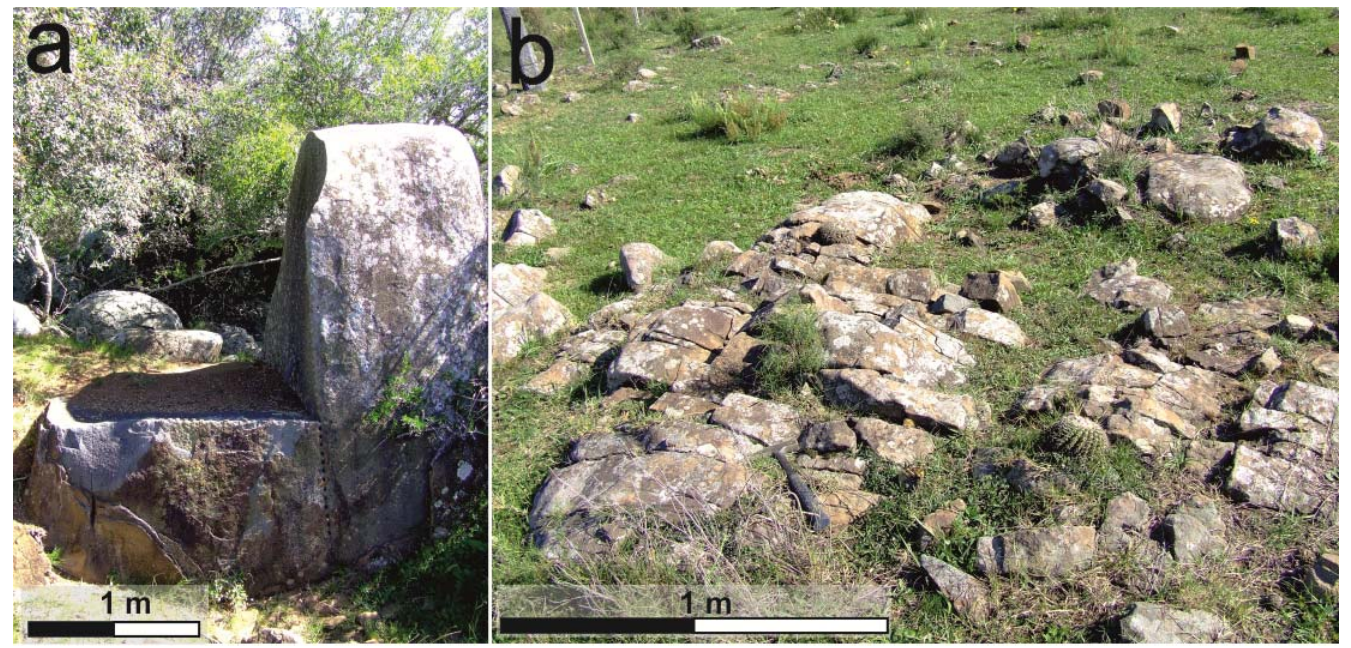

Fig. 2.21: a. Large boulder of dolerite weathered in place; b. Poorly exposed dolerite outcrop. 
Table 2.6: Summary of dikes sampled.

\begin{tabular}{|c|c|c|c|c|c|c|c|}
\hline Sample & $\begin{array}{l}\text { Quarry I } \\
\text { Location }\end{array}$ & $\begin{array}{l}\text { Dike Width } \\
(\mathrm{m})\end{array}$ & $\begin{array}{l}\text { Present } \\
\text { condition }\end{array}$ & $\begin{array}{l}\text { Quarry Depth } \\
\text { (m) }\end{array}$ & $\begin{array}{c}\text { Quarry I } \\
\text { Outcrop } \\
\text { Length }(\mathrm{m})\end{array}$ & $\begin{array}{c}\text { Dike } \\
\text { Length } \\
(\mathrm{m})\end{array}$ & Strike \\
\hline \multicolumn{8}{|l|}{ Group A } \\
\hline U8 & Rosarito & 41 & in activity & at least 8 & 100 & 3500 & $\mathrm{~N} 060^{\circ}$ \\
\hline U11 & Blackstone & 38 & in activity & 8 & 140 & 500 & $\mathrm{~N} 080^{\circ}$ \\
\hline U12A & Talita grande & 25 & flooded & at least 4 & 135 & 2000 & $\mathrm{~N} 075^{\circ}$ \\
\hline U12B & Talita chica & 20 & flooded & at least 3 & 150 & 2000 & $\mathrm{~N} 080^{\circ}$ \\
\hline U55 & Mexico & 30 & flooded & at least 6 & 135 & 1500 & $\mathrm{~N} 053^{\circ}$ \\
\hline U56 & Los Fresnos & 30 & abandoned & superficial & 170 & 3400 & $\mathrm{~N} 060^{\circ}$ \\
\hline U59 & Omar Méndez & 40 & flooded & at least 4 & 110 & 1250 & $\mathrm{~N} 070^{\circ}$ \\
\hline U62 & Las Acacias & 19 & flooded & 5 & 130 & 2600 & $\mathrm{~N} 072^{\circ}$ \\
\hline U64 & Pintado & 35 & abandoned & superficial & 430 & 430 & $\mathrm{~N} 075^{\circ}$ \\
\hline U215 & La Sierra & 16 & no quarry & - & 220 & 500 & $\mathrm{~N} 056^{\circ}$ \\
\hline \multicolumn{8}{|l|}{ Group B } \\
\hline U13 & Victor & 30 & abandoned & 8.5 & 110 & 1900 & $\mathrm{~N} 076^{\circ}$ \\
\hline U58 & Boria & 30 & flooded & at least 5 & 120 & 1700 & $\mathrm{~N} 076^{\circ}$ \\
\hline U61 & Inex & 25 & flooded & 11 & 225 & 2400 & $\mathrm{~N} 065^{\circ}$ \\
\hline U66 & Pimafox & 24 & in activity & 4 & 60 & 2000 & $\mathrm{~N} 072^{\circ}$ \\
\hline U199 & Arroyo Polonia & 20 & no quarry & - & 55 & 560 & $\mathrm{~N} 065^{\circ}$ \\
\hline U243 & Arroyo de la Quinta & 30 & no quarry & - & 120 & 800 & $\mathrm{~N} 050^{\circ}$ \\
\hline
\end{tabular}

2.4.2. Characterization of dolerite deposits: controlling parameters

The main controlling parameters affecting the deposits of dimensional stones are the volume of the deposit, the ensemble of lithological aspects (e.g. fabric, mineralogy, geochemistry, etc.) and the tectonic inventory.

The volume is important because enough material has to be present in order to furnish a steady product for regional or international markets, and thus such an occurrence can be considered as a suitable provider. The dolerite deposits are characterized by their tabular shape, being a two-dimensional deposit. The volume of the deposit is limited by the length of the dike and its width, whereas the depth is determined by how deep it is technologically possible to mine.

In Uruguayan deposits the maximum depth that has been reached in a dolerite quarry is around $10 \mathrm{~m}$. Medina and Carrión (1987) reported that in the quarries U12A 
and U12B drillings were performed, but any report on the results is lacking. This is also the case of drillings in the quarry U8, where the drill cores are available but the drilling location and direction is unknown, so that it is impossible to know the depth of drilling. The maximum mining depth in this kind of deposit has been attained in the dolerite quarries of Sweden, where the extraction of blocks can reach up to 50 meters.

The second controlling parameter is the ensemble of lithological aspects that indicates if the rock is suitable as a dimensional stone, since these influence the décor, e.g. the color and fabric of the rock. For black dimensional stones, the intensity and homogeneity of the black color is very important, so that no other color spots are present. Exceptions to this assumption are the cases where such heterogeneities make an improvement in the quality of the décor, e.g. the Star Galaxy from India or Black Galaxy from Brazil.

Tectonic elements are the third controlling parameter. The main structural elements are joints, which are mainly distributed as orthogonal sets and are probably the result of the cooling and contraction of the rock.

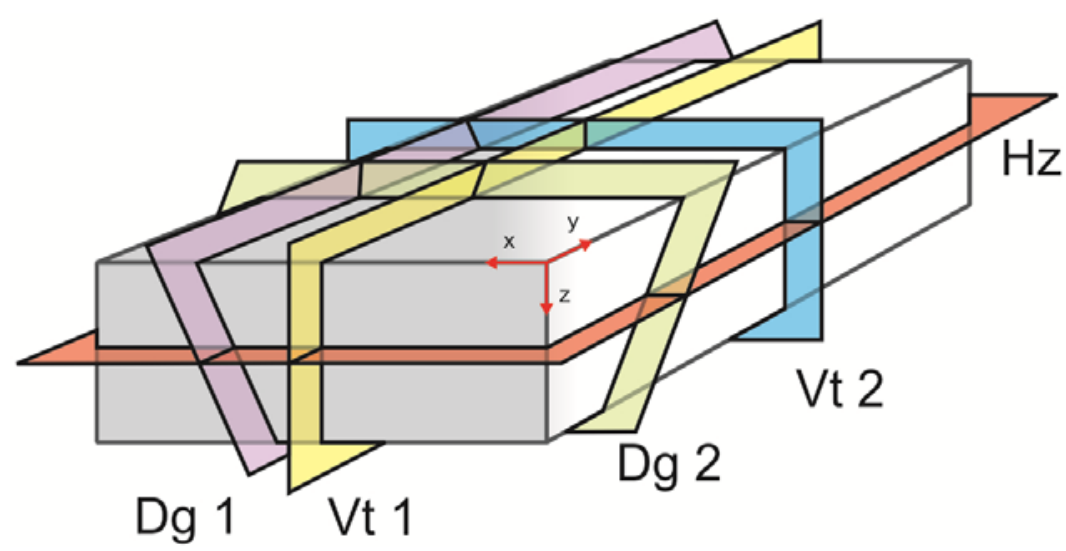

Fig. 2.22: 3D model of joint sets found in dolerite dikes. $X$ direction: dike width, y direction: dike length, z direction: depth. Hz: horizontal, Vt 1: vertical 1 (parallel to dike length), Vt 2: vertical 2 (perpendicular to dike length), Dg 1: diagonal 1 (parallel to dike length) and Dg 2: diagonal 2 (perpendicular to dike length).

In figure 2.22 the main joint sets are represented, which were observed in all the investigated dikes. Previous authors (e.g. Medina and Carrión, 1986; 1987; Bossi 
and Campal, 1991) have also reported on these joint sets. Three main joint sets occur, two sub-vertical and one horizontal. The two sub-vertical sets are orthogonal: one parallel to the dike walls striking $070-085^{\circ}$ and dipping towards the NW or SE (represented as Vt 1 in Fig. 2.22), and the other one perpendicular to the dike walls striking to $320-360^{\circ}$ and dipping towards the NE or SW (represented as Vt 2 in Fig. 2.22). The sub-horizontal joint set shows dips up to $10^{\circ}$ in all directions.
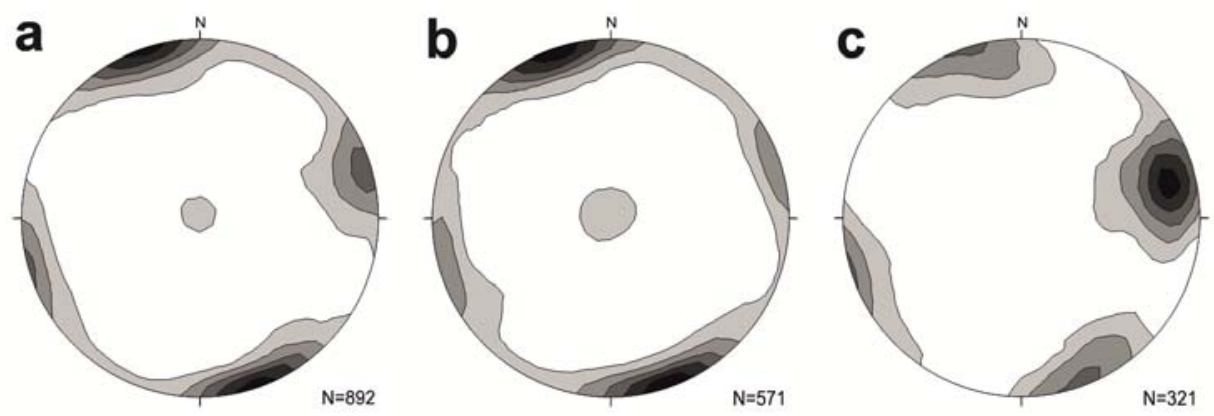

Fig. 2.23: a. Total joints measured; b. Joints measured in Group A dikes; c. Joints measured in Group B dikes. Stereograms: equal area, lower hemisphere. Contours: 1, 2, 3, 4, 5 times uniform distribution.

The distribution of the joints in several quarries has been measured in order to calculate the potential block size that can be extracted. The first two joint sets observed are represented in the plots of Figure 2.23. A meaningful difference in the orientation of the joints cannot be observed between the dikes of Groups A (High $\mathrm{TiO}_{2}$ ) and $\mathrm{B}\left(\mathrm{Low} \mathrm{TiO}_{2}\right)$. However, the dikes of Group $\mathrm{A}$ display a higher frequency of joints parallel to the dike wall, whereas the dikes of Group B show a higher frequency of joints perpendicular to the dike wall and of joints that dip to the SW. Since these joint sets are orthogonal to each other, regular-sized blocks can be quarried. If the spacing between the joints is large enough, the quarry is able to produce blocks on a profitable basis.

The problem with this type of deposit is the existence of other joint sets that crosscut the orthogonal ones. Diagonal joints have also been previously described by Bossi and Campal (1991) and Medina and Carrión (1986). Although these joints are not very frequent, their significance for the quarrying operation is very important as they crosscut the regular blocks that could be extracted, increasing the proportion of waste material and minimizing the production of marketable blocks (Fig. 2.24). In 
statistical documentations they are often overseen (Fig. 2.23). Diagonal joints have been isolated in the plots of Figure 2.25 in order to better visualize them.
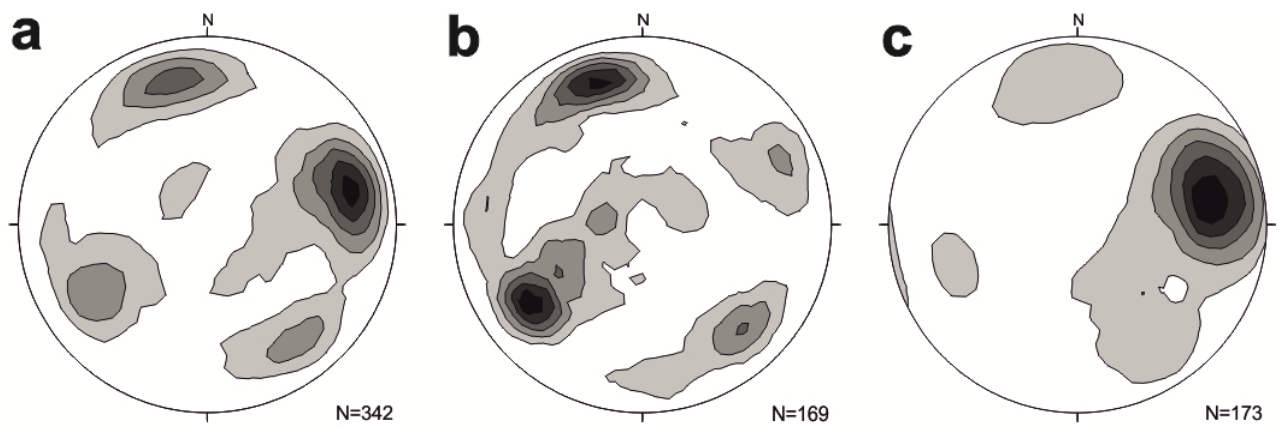

Fig. 2.25: a. Total diagonal joints measured; b. Diagonal joints measured in Group A dikes;

c. Diagonal joints measured in Group B dikes. Stereograms: equal area, lower hemisphere. Contours: $1,23,4,5$ times uniform distribution.

The two diagonal sets are also orthogonal to the dike direction and both have dips between 11 to $75^{\circ}$. One diagonal set strikes N070-085 and dips towards the NW or SE (Dg 1 in Fig. 2.22), and the other one strikes N320-360 and dips to the NE or SW (Dg 2 in Fig. 2.22).

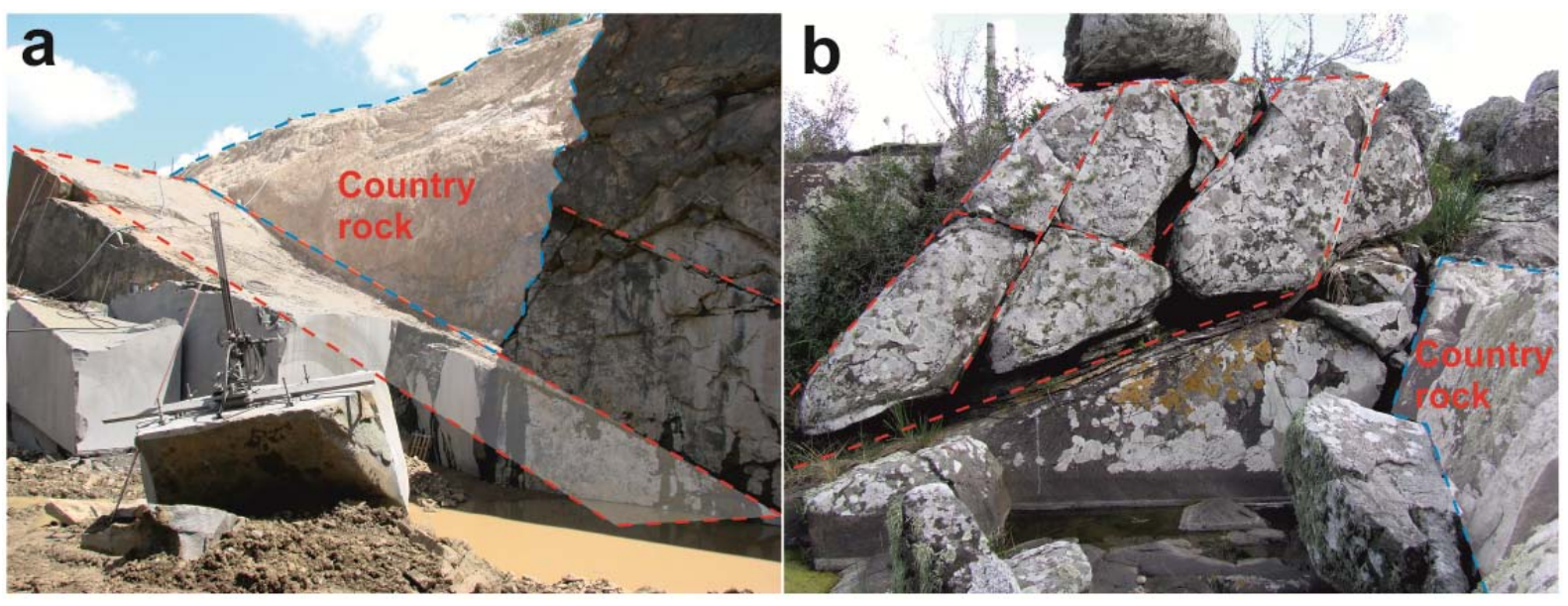

Fig. 2.24: a. Diagonal joint dipping parallel to the dike walls; b. diagonal joints dipping perpendicular to the dike walls.

\subsubsection{Quality assessment of dolerite deposits}

All the dikes can be subdivided into three zones by their grain size: Zone 1 (very finegrained), Zone 2 (fine-grained) and Zone 3 (medium-grained). In quarries located in the dikes of Group A, in which their Zone 2 is unfractured, field observations indicate 
that the Absolute Black variety can be mined (e.g. Black Stone Quarry, see Fig. 2.9). The Moderate Black variety (Negro Oriental in Uruguay) is extracted from Zone 3. Since Zones 1 and 2 are not more than $11 \%$ of the dike, the ratio between Absolute Black and Moderate Black is at best 0.124 .

Several decades ago the scarcity of joints in a dimensional stone deposit was a very negative aspect for the extraction, because they could not be used to facilitate the mining of the blocks (Bossi and Campal, 1991). Today the diamond wire saw makes it possible to cut a block of dolerite without any previous discontinuity. However, the problem of a greater proportion of joints in a quarry persists, which is one of the controlling factors in the quarrying of dolerite deposits.

\subsubsection{Characterization of the waste material}

Before starting the extraction of any dimensional stone, the weathered material (including rounded boulders) and sedimentary deposits that covers the fresh rock must be removed. These materials are called overburden or simply waste rock. In addition to these materials, an important amount of country rock (no matter if fresh or weathered) must also be extracted for safety reasons (instabilities etc.) while quarrying. Considering a mining depth of $50 \mathrm{~m}$, a width of $30 \mathrm{~m}$ and a dike dip angle of $89^{\circ}$, the proportion of waste rock to be removed is about $6.5 \%$ of the total volume extracted and $26 \%$ when the dip is $70^{\circ}$. However the amount of waste rock will significantly increase by lower depths of exploitation as realize today in Uruguay (maximum depth up to $10 \mathrm{~m}$ ).

Another kind of waste rock produced comes from the sections of the quarry where a high frequency of fractures occurs. No production of profitable blocks can be performed in these sections (Fig. 2.26). When the extracted block, which differs from a rectangular cuboid, is squared into one, new waste rock is produced that is highly dependent on the joint systems. Internationally, the waste material produced in dimensional stone quarries is around $30-50 \%$ of the extracted volume; however in Uruguayan dolerite quarries this value can reach up to $90 \%$ (Oyhantçabal et al, 2007a). 

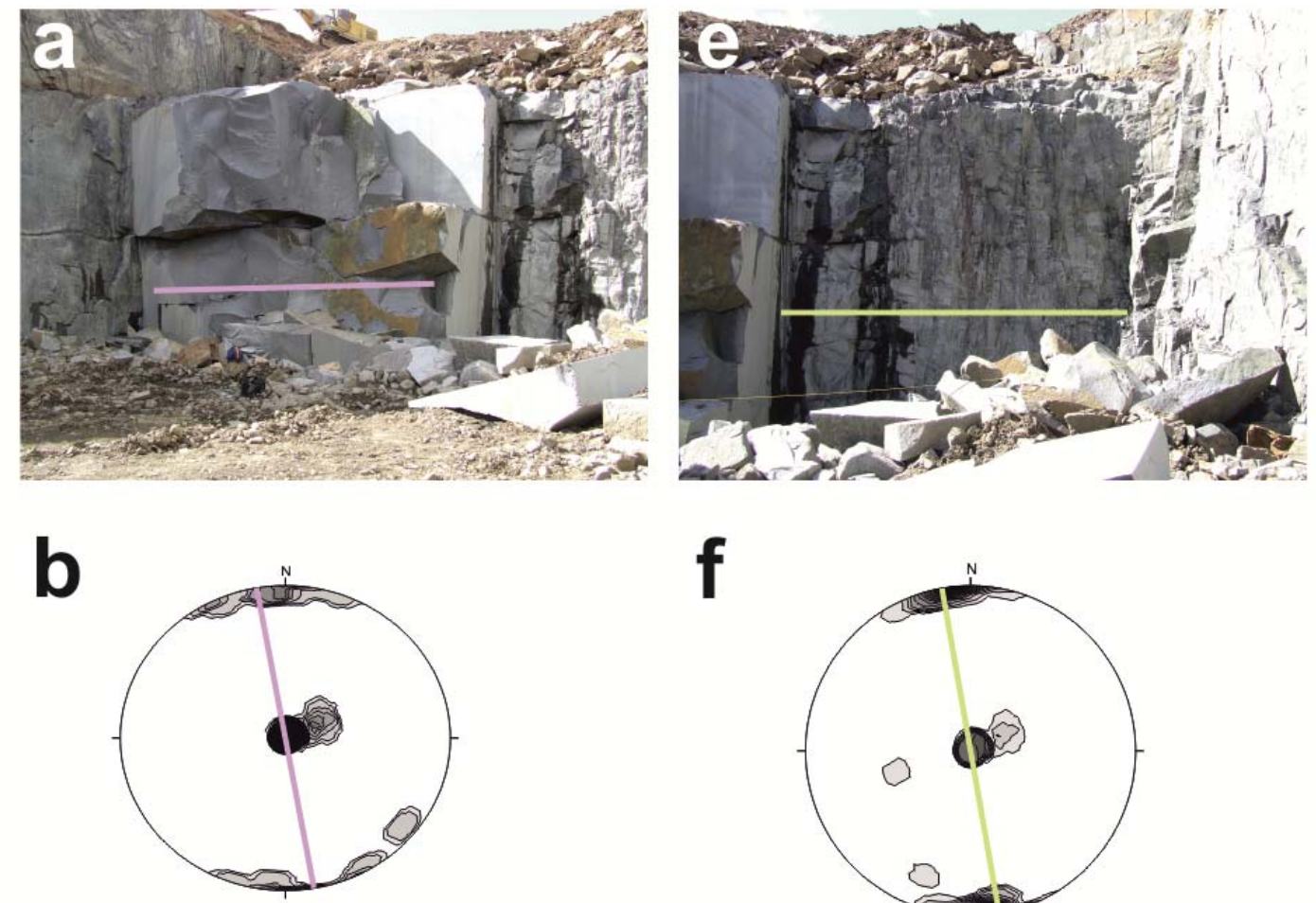

f
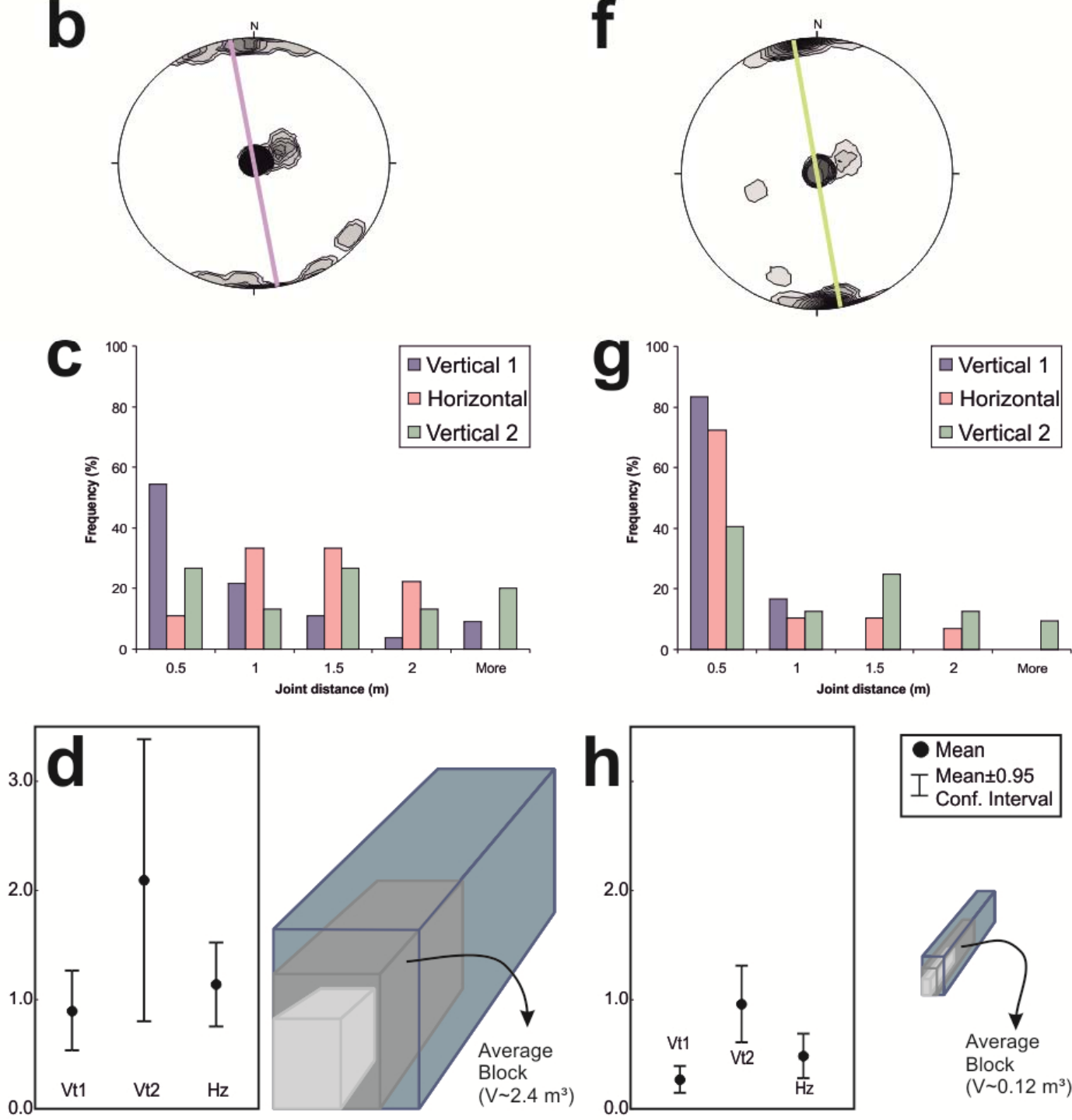

Fig. 2.26: Comparison of two sections of a dolerite dike: a. Section suitable for quarrying dolerite blocks; b. stereogram showing joint distribution; c. diagram showing distances between joints; $\mathbf{d}$. box plots showing average distances between joints and the minimal, average and maximal block that can be extracted; e. section only suitable for quarrying gravel; f. stereogram showing joint distribution; $\mathbf{g}$. diagram showing distances between joints; $\mathbf{h}$. box plots showing average distances between joints and the minimal, average and maximal block that can be extracted. 


\subsection{Petrophysical properties}

The petrophysical investigations were carried out in the laboratories of the Department of Structural Geology and Geodynamics of the Geoscience Centre of the University of Göttingen, whereas the abrasion strength test (AST) was conducted at the laboratories of AMPA (Amtliche Materialprüfanstalt für das Bauwesen) of the University of Kassel. The materials used for the petrophysical testing are samples from Zone 2 and Zone 3 from the Black Stone Quarry (U11), which is located in a dike from Group A; and of samples of Zone 3 from the Pimafox Quarry (U66), located in a dike from Group B. All the results of the petrophysical properties are listed in Tables A.2.1, A.2.2, A.2.3 and A.2.4 in appendix. Table 2.7 shows the main petrophysical properties of other comparable black dimensional stones, such as basic plutonic rocks or volcanic rocks.

\subsubsection{Density, porosity and thermal expansion}

Density values are similar to gabbro-dioritic rocks, to which they can be compared. For the Oriental Dolerite variety the bulk density value is $2.97 \mathrm{~g} / \mathrm{cm}^{3}$ and for the Moderate Black the value is $3.02 \mathrm{~g} / \mathrm{cm}^{3}$. In both varieties the real density is quite similar, $2.98 \mathrm{~g} / \mathrm{cm}^{3}$ for the Oriental Dolerite and $3.02 \mathrm{~g} / \mathrm{cm}^{3}$ for Moderate Black. The density values of some comparable rocks vary between 2.8 (for Impala and Star Galaxy) and $3.3 \mathrm{~g} / \mathrm{cm}^{3}$ (for Ebony Black) (see Table A.2.1).

The dolerites have very small values of porosity under vacuum, around $0.03 \%$ for Absolute Black and $0.12 \%$ for Oriental Dolerite. Their pore radii distribution shows that the most abundant pore radii class is $0.01 \mu \mathrm{m}$ for Absolute Black and $0.08 \mu \mathrm{m}$ for Oriental Dolerite, whereas the average pore radii is $0.10 \mu \mathrm{m}$ for Absolute Black and $0.21 \mu \mathrm{m}$ for Oriental Dolerite.

The vacuum and atmospheric water uptakes are very low, 0.01 for Absolute Black and 0.03 and $0.04 \%$ for Oriental Dolerite due to the low porosity values. The values of the comparable rocks in Table 2.7 vary between 0.05 and $0.33 \%$, for Preto Absoluto and Shanxi Black, respectively. 
| Case study: Dolerites

Table 2.7: Technical properties of comparable black dimensional stones (source: Börner and Hill,

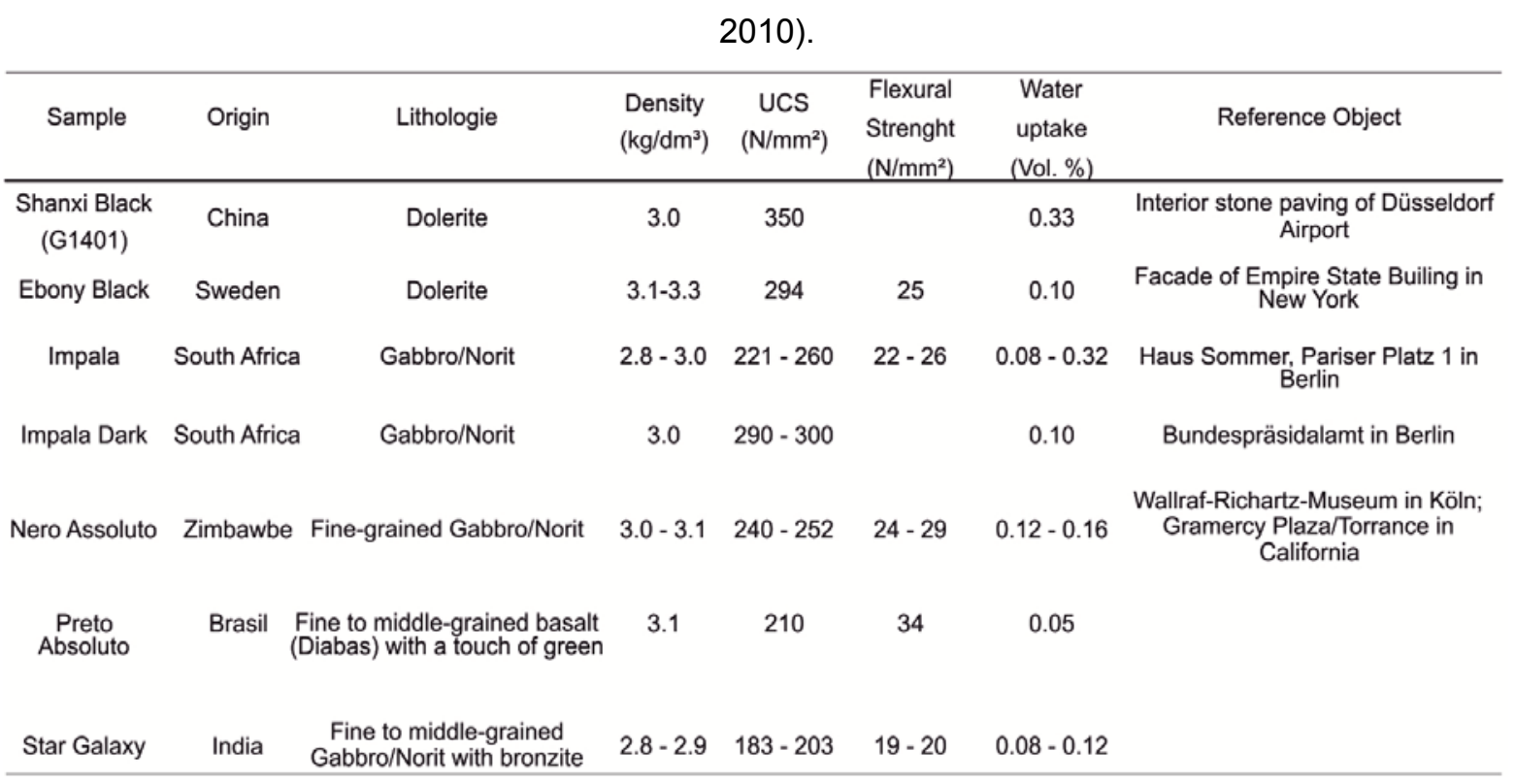

The thermal expansion differs between $5.67^{*} 10^{-6} \mathrm{~K}^{-1}$ for Oriental Dolerite and $6.90^{*} 10^{-6} \mathrm{~K}^{-1}$ for Moderate Black (Tab. A.2.2). These values can be compared to those determined by Hoffman (2006) for a hornblendite $\left(6.64^{*} 10^{-6} \mathrm{~K}^{-1}\right)$. There is no permanent change in length after the heating/cooling-cycles.

\subsubsection{Mechanical properties of black dimensional stones}

The dolerite Absolute Black shows uniaxial compressive strength (UCS) values that vary between $367 \mathrm{MPa}$ in the z-direction and $400 \mathrm{MPa}$ in the $\mathrm{x}$-direction (Table A.2.3). Oriental Dolerite shows the lowest value: $260 \mathrm{MPa}$ in the $y$-direction. The UCS values for basic plutonic rocks range from around $90 \mathrm{MPa}$ to $400 \mathrm{MPa}$ (Mosch, 2008) (Fig. 2.27a and b). The Young's modulus for Oriental Dolerite was determined to be $15.0 \mathrm{GPa}$ in the z-direction and $29.2 \mathrm{GPa}$ in the $\mathrm{x}$-direction, whereas for Absolute Black the values are $29.60 \mathrm{GPa}$ in the y-direction and $32.90 \mathrm{GPa}$ in the $\mathrm{x}$ direction.

The tensile strength values determined for the Uruguayan dolerites are between 16.7 $\mathrm{MPa}$ in the $\mathrm{x}$-direction and $19.5 \mathrm{MPa}$ in the $\mathrm{y}$-direction for the Absolute Black, and between $14.3 \mathrm{MPa}$ in the $z$-direction and $14.7 \mathrm{MPa}$ in the $\mathrm{x}$-direction for the Oriental 
Dolerite (Table A.2.3). According to Mosch (2008), the tensile strength for basic plutonic rocks is around $28 \mathrm{MPa}$.
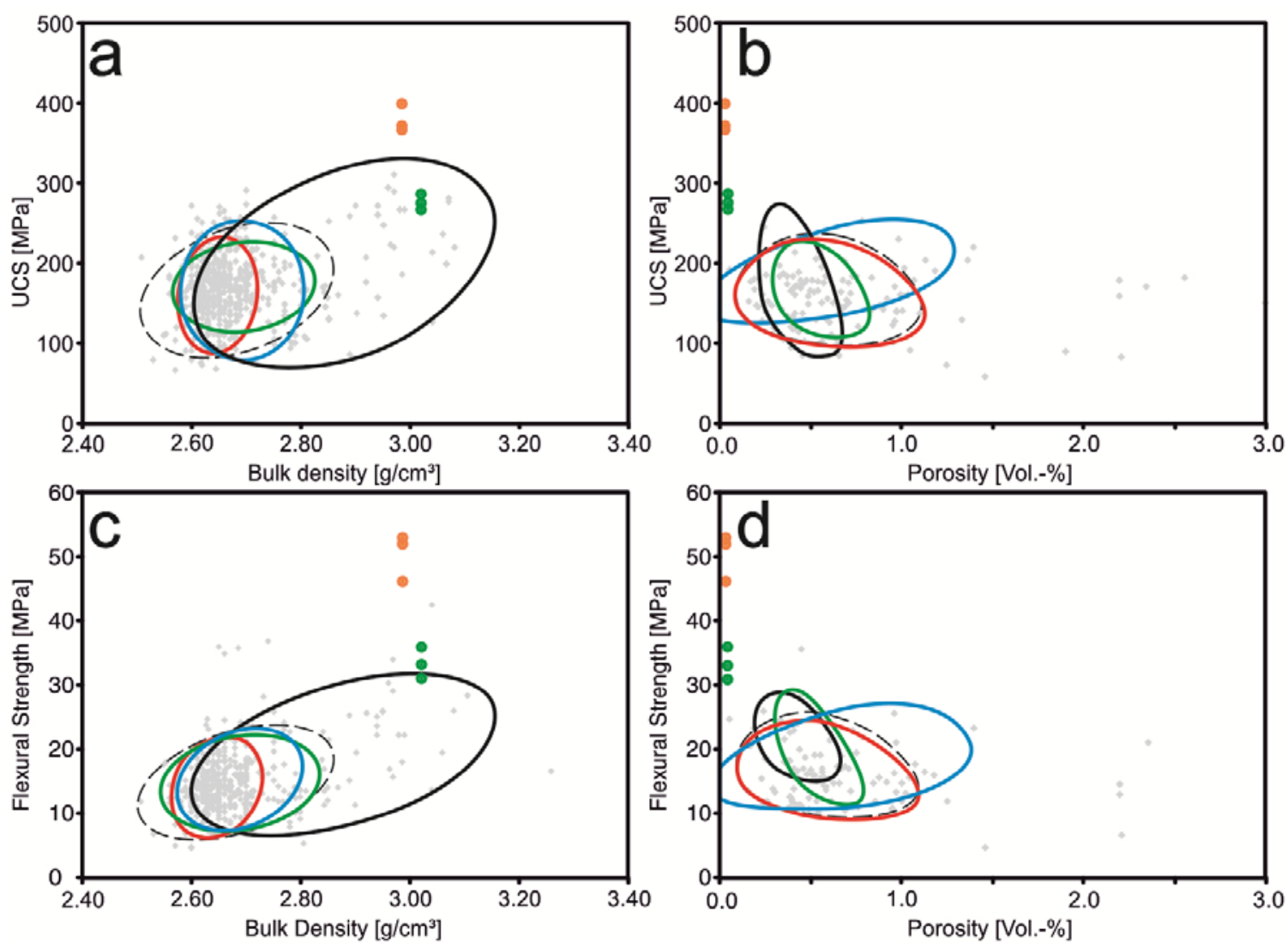

¿ Plutonite total $\bigcirc$ Gabbro, Diorite $\bigcirc$ Granite $\bigcirc$ Granodiorite, Tonalite $\bigcirc$ Monzonite, Syenite $\bullet$ Absolute Black Dol. $\bullet$ Moderate Black Dol.

Fig. 2.27: a. UCS vs. bulk density; b. flexural strength vs. bulk density;

c. UCS vs. porosity; d. flexural strength vs. porosity (modified after Mosch, 2008).

The flexural strength values vary between 46.06 MPa in the z-direction and 52.75 $\mathrm{MPa}$ in the y-direction for the Absolute Black dolerite, and between 35.72 MPa in the $\mathrm{x}$-direction and $30.81 \mathrm{MPa}$ in the y-direction for the Moderate Black dolerite (Table A.2.4). The flexural strength values for basic plutonic rocks are around 5 to $30 \mathrm{MPa}$ (Mosch, 2008) (Fig. 2.27c and d). The breaking load at the dowel hole is 4.7 MPa for Absolute Black and 3.6 MPa for Oriental Dolerite.

The abrasion strength varies between $2.2 \mathrm{~cm}^{3} / 50 \mathrm{~cm}^{2}$ in the z-direction and 2.4 $\mathrm{cm}^{3} / 50 \mathrm{~cm}^{2}$ in the $y$-direction for Absolute Black and 2.0 in the $\mathrm{x}$-direction and 2.1 $\mathrm{cm}^{3} / 50 \mathrm{~cm}^{2}$ in the $y$ - and z-directions for Oriental Dolerite (Table A.2.4). These are very low values considering the values given by Hoffmann (2006) for diorite, between 
$7.5 \mathrm{~cm}^{3} / 50 \mathrm{~cm}^{2}$ and $15 \mathrm{~cm}^{3} / 50 \mathrm{~cm}^{2}$, meaning that the Uruguayan dolerites show a high resistance to material loss due to abrasion.

2.6. Summary evaluation of the "black stone" deposits

\subsubsection{Quality assessment with respect to color and décor}

Dolerites are valuable dimensional stones, mainly because of two distinct properties: their black color and the possibility of extracting them in larger blocks. The black color is directly related to the décor, and therefore to three properties of the rock: the mineral composition, the texture (which includes grain size, grain shape, and its interlocking flow structures and the observed reaction textures) and the structure (e.g., layering or inclusions). The latter two belong to the rock fabric.

The minerals that determine the black color are melanocratics such as pyroxene, hornblende, opaques and biotite. Changes in the color can be produced when leucocratic minerals are present or minerals resulting from autohidrothermal reactions. Minerals such as plagioclase, alkali feldspar and quartz-feldspar intergrowths create white spots in the rock. Green spots are developed when hornblende is present.

The value of black stones increases when the minerals are homogeneously distributed in the rock, exhibit no flow textures, visible intergrowths, nor reaction textures or any visible structure that alters the black color of the rock. If melanocratic minerals are homogeneously distributed, then the rock will have a homogenous color, which can be black or gray depending on their proportion and on the grain size of the rock. Rocks with a finer grain size and the same percentage of melanocratic minerals tend to be darker. Layering in a black rock affects it negatively, as well as the presence of veins of leucocratic minerals.

For all black dimensional stones three color qualities are defined: absolute black, moderate black and special black. The absolute black color in a dimensional stone can be developed in three different cases. First, when the rock is composed of $100 \%$ melanocratic minerals. Secondly, the rock is composed of melanocratic and 
leucocratic minerals and the latter contain inclusions of melanocratic minerals, and when the grain size is extremely fine.

The moderate black color can be generated when the melanocratic minerals make up 30 to $60 \%$ of the rock and the grain size is coarse (up to $2 \mathrm{~mm}$ ) making both mineral colors distinguishable. Three special cases can arise which affects the color of moderate black stones. The first can occur in both varieties when there are minerals present that interrupt the normal color of the stone. Two examples of this are the presence of granophyric intergrowths that produce white spots and the presence of broncite in gabbro that produces golden spots (such as in the Star Galaxy variety of India). Autohidrothermal alteration creates the second special case where whole color changes are produced in the rock. This occurs by the process of uralitization that produces a slightly green coloration. The third situation is given when the rock is cut by veins of different color or layering is present that modifies the whole rock color.

The color index of the Uruguayan dolerites calculated using normative minerals varies between 31 and 33\% in Group A and is 33\% in Group B. When the color index is calculated using modal analysis, the values are higher. Zone 2 in both groups shows higher modal $M$ values than Zone 3. Zone 3 of Group A shows lower M values (38\%) with respect to Group B (47\%), and in both groups Zone 2 can have the same $M$ value $(49 \%)$. The rock is therefore classified as mesocratic using both, the normative and the modal $\mathrm{M}$ value.

Color variations are related to changes in the grain size, which determines the quality of the main rock varieties. In Uruguayan dolerites, the color of the Absolute Black variety is until now only found in the dikes of Group A. The most important characteristic of Absolute Black is the very small grain size and its homogeneity. The porphyritic texture observed in Zone 2 of some deposits drastically reduces its quality.

The Moderate Black variety develops a dark gray color, in both groups. This is due to the medium grain size of the leucocratic and melanocratic minerals that are distinguishable without any optical aid. 
Grain size variations are sometimes visible on the sides of the extracted and squared blocks. A clear layering of melanocratic and leucocratic minerals was not observed, however in three quarries (two classified as Group A and one as Group B) the presence of leucocratic veins has been observed.

Autohidrothermal alteration can have a negative influence on the color in some parts of a deposit, especially in combination with a porphyritic texture as in Zone 2. When the autohidrothermal alteration is homogenously distributed throughout the entire deposit the quality of the Moderate Black variety is not negatively affected.

Granophyric intergrowths are visible as white spots within a black background, when they are larger than one millimeter. These intergrowths affect the quality of the Absolute Black more negatively than the Moderate Black variety, because the latter one already has coarse white spots (the plagioclase laths) that are homogeneously distributed.

From the color measurement results it can be concluded that Absolute Black dolerite is the darkest of the black dimensional stones considered in this study, followed by Shanxi Black, Yi and Dark Larvikite. The $a^{*}$ parameter for the samples analyzed is generally positive (in one sample negative) and very low, indicating that there is a very small proportion of red color in these rocks. The $b^{*}$ value is also generally positive (in one case negative) and very low, indicating that the rocks studied also have a proportion of yellow in their color. The values $a^{*}$ and $b^{*}$ for the samples considered are so small that they have no influence on the color of the sample, which is determined only by the $L^{*}$ value.

Utilizing the classification scheme of Motoki and Zucco (2005), the rocks analyzed in this study are black and dark gray. Absolute Black dolerite is black, as well as Shanxi, Yi, Dark Larvikite and Brazil Black and Moderate Black dolerite is dark gray, as well as the rest of the rocks analyzed. 


\subsubsection{Petrophysical aspects}

The application and use of dimensional stones is finally controlled by the technical requirements and petrophysical properties. Under normal conditions in a building the technical requirements of a dimensional stone are moderate. Extreme applied loads are seldom. More often the dimensional stones have to show high flexural strength and high resistance to the climatic conditions or the chemical reactants to which they can be exposed to.

In comparison to other black rocks on the international market, the Uruguayan dolerites have similar or even better physical (technical) properties. Particularly the Absolute Black variety shows a maximal compressive strength of $400 \mathrm{MPa}$ and a maximal flexural strength of around $50 \mathrm{MPa}$. With such high resistance values, these rocks can be used safely in many building parts that require a high compressive and flexural strength.

The low porosity, water uptake, thermal expansion and also the high abrasive resistance of the rock makes it an appropriate material for counter-tops and precision tables for technical/industrial purposes. These types of constructions usually require a high quality, pertaining to their physical, chemical and geometrical properties (e.g., length measures changes, susceptibility to chemical reactions, evenness of the surface, high strength, etc.).

\subsubsection{Block sizes distribution and modeling}

The dimensions of the preferred blocks are determined by the industrial processes that follows the extraction. The blocks are required to be rectangular cuboids (or right rectangular prisms) without irregularities (such as veins or joints) and with the specified dimensions required for extractable raw blocks. These dimensions determine whether the block is of minimum, optimal, maximal or special size. The minimum block is determined by the smallest piece that can be commercialized, which is a gravestone. The optimal block must have the adequate dimensions to be cut in a diamond gang saw. The available transport conditions possibilities determine 
the maximal weight of a block and therefore the dimensions of the maximal block. The special blocks are determined by the demand. For example, precision tables for technical/industrial purposes may require the blocks to have the dimensions of three meters long, one meter wide and half a meter thick.

Uruguayan dolerites have a density of $3 \mathrm{t} / \mathrm{m}^{3}$ and the maximum block weight cannot exceed 28 tons, because this is the maximum weight that can be transported in containers. The different block dimensions can be distinguished into: small ones (between 0.5 and $1 \mathrm{~m}^{3}$ ), medium blocks (between 1 and $3.3 \mathrm{~m}^{3}$ ), large blocks (between 3.3 and $6.6 \mathrm{~m}^{3}$ ) and very large blocks (larger than $6.6 \mathrm{~m}^{3}$ ). The maximum block must be smaller than $9 \mathrm{~m}^{3}$.

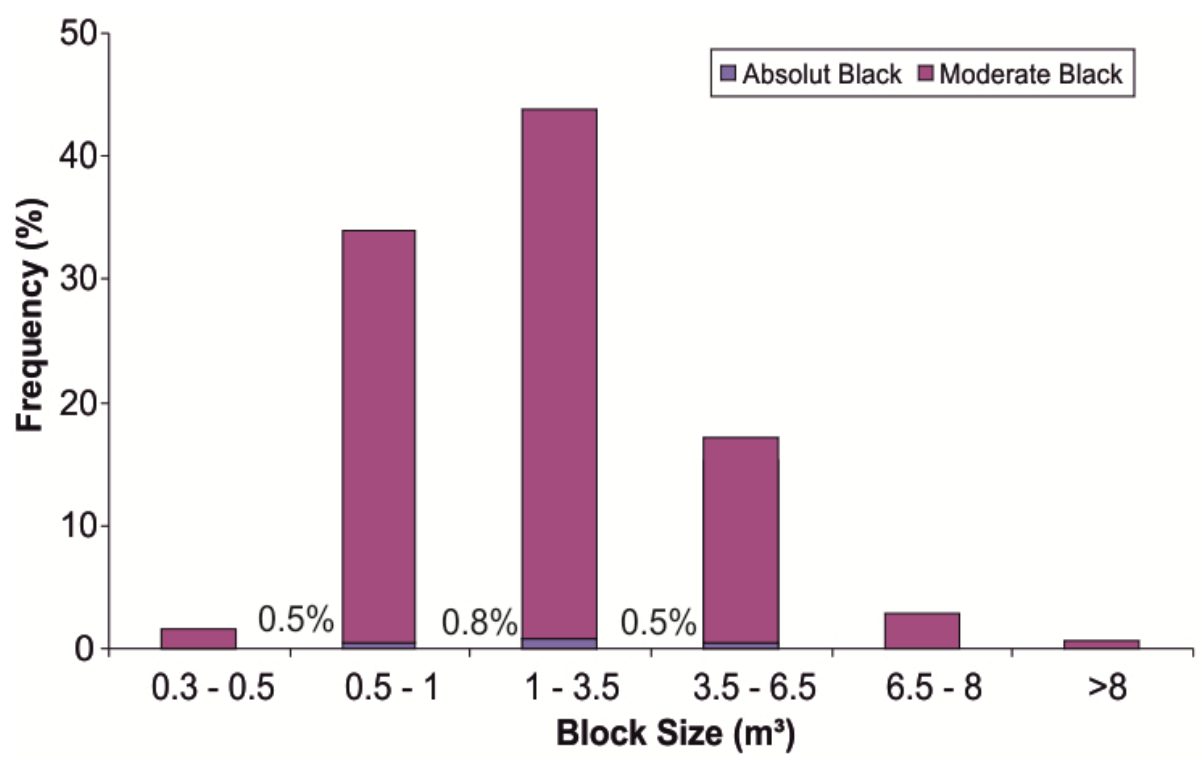

Fig. 2.28: Production between 2005 and 2009 for the Black Stone Quarry. Block size frequency distribution of the Group A quarry for both color varieties (Source: Personal communication with Black Stone Quarry owner).

The Black Stone Quarry is a good example for illustrating block production from a dolerite deposit in Uruguay. Between the years 2005 and 2009, this quarry produced a total of $2,536 \mathrm{~m}^{3}$ as shown in the block size frequency diagram in Fig. 2.28. Most of the block sizes produced is of the small dimensions with $34 \%$ of the total production and the medium dimension making up $44 \%$. Large blocks represent $17 \%$, the maximum blocks and the very large blocks come to $2.8 \%$ of the total production. The proportion of Absolute Black in production is very low, being $1.8 \%$ for the production 
time span considered, $0.5 \%$ belongs to the small blocks, $0.8 \%$ to the medium and $0.5 \%$ to the large blocks.

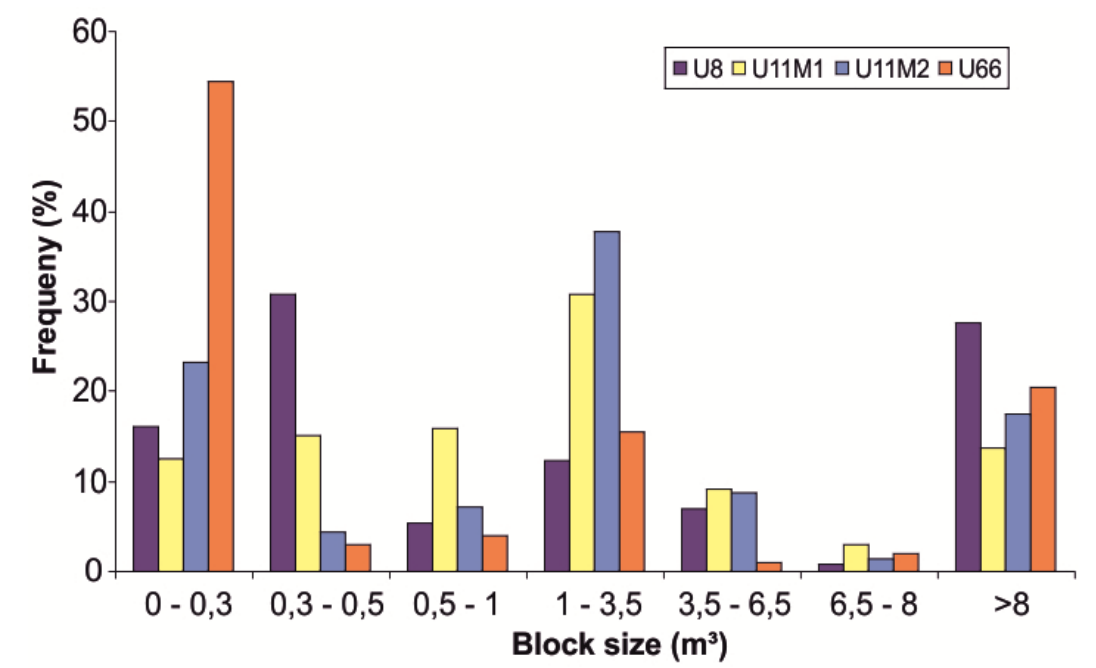

Fig. 2.29: The raw block size distribution modeled for the three quarries investigated using the 3DBlock Expert program.

Sections of three quarries were modeled using the program 3D-Block Expert developed at the University of Göttingen (see Siegesmund et al, 2007; Mosch, 2008 and Mosch et al, 2011, for details). The raw block size distribution for the models obtained is shown in Figure 2.29.

For the Black Stone Quarry a section having the dimensions $(8 \times 8 \times 6 \mathrm{~m})$ has been modeled (Fig. 2.30a, c and d) and the block size distribution analyzed in order to determine its potential yield. The resulting prism is cut into slabs of 1 meter each (Fig. $2.30 \mathrm{~b}$ ) and then a possible block distribution can be proposed (Fig. 2.31). From inclined joints it is evident that the block sizes do not match any minimum raw block volume, which corresponds to a higher amount of waste (Fig. 2.31).

The deposits are characterized by their two-dimensional shape and their limited width, where the extraction can either develop along the length or with depth. The length of one single dike can be up to 3,500 meters, such as the dike of the PoloniaPichinango area, but normally they only attain a length of 1,000 meters. The depths of the dikes in the study area are unknown, but in other parts of the world economic mining in such deposits can reach 50 meters. Normally the dikes do not exceed a 
width of 40 meters. The economically more interesting ones are those wider than 15 meters, because initial observations show that the thinner dikes have a finer grain size and a greater proportion of Absolute Black. The dip of the quarry walls can present a problem for mining safety, especially when a certain depth is reached. The joint sets determine the efficiency of the quarry, because they control the block size and the amount of waste rock that will be produced.

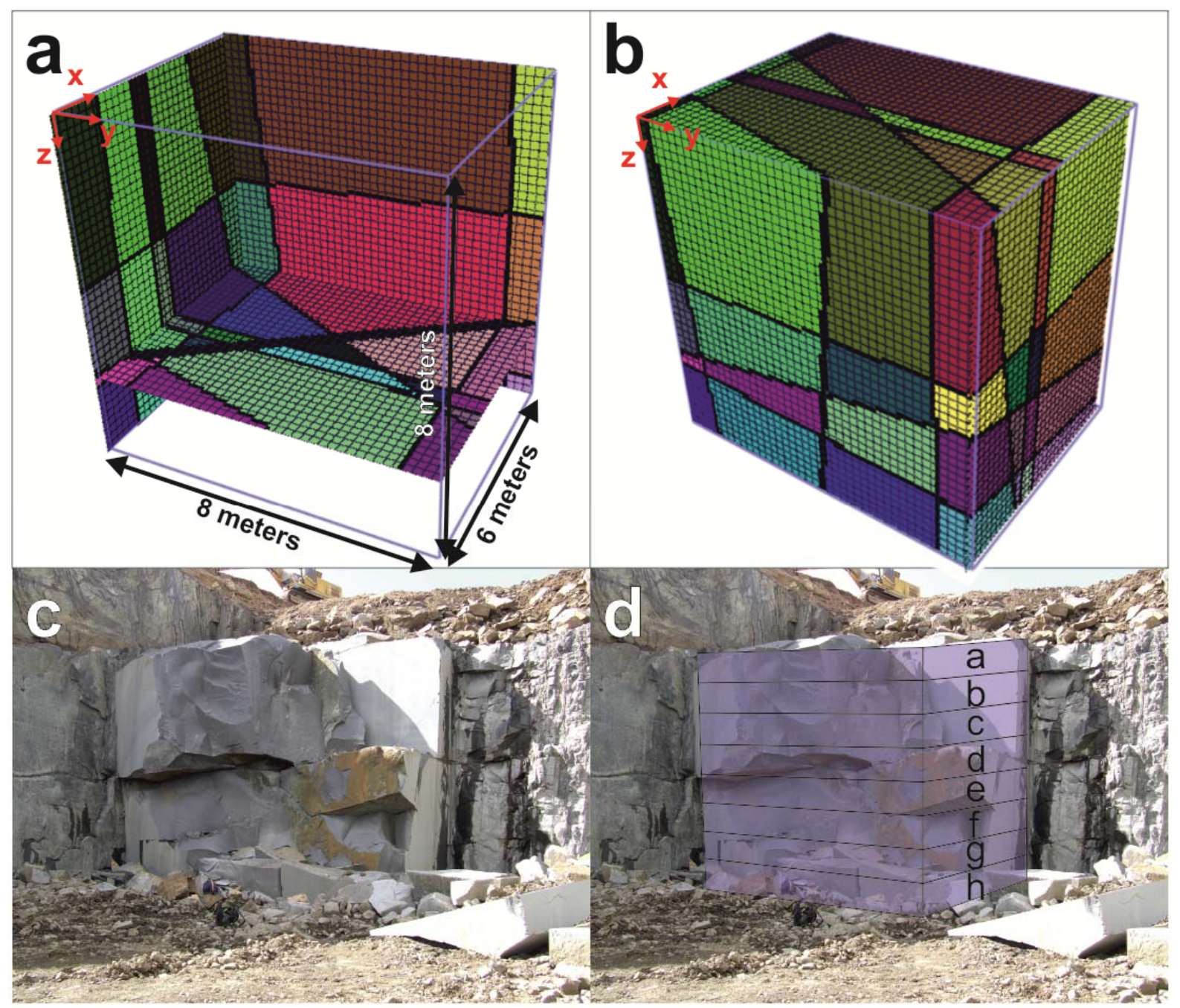

Fig. 2.30: a. and b. Section in the Black Stone Quarry modelled with 3D-Block Expert ( $x=6, y=8$ and $z=8 \mathrm{~m}$ ) and represented with Intel $\circledast$ Array Viewer. The different joint sets can be seen as well as the cross-cutting diagonal joints; $\mathbf{c}$. Image of quarry section modelled; $\mathbf{d}$. Image of quarry section modelled with slabs (one meter each) represented.

When planning a mine based on the geometry of the deposit, the efficiency of the mining operation increases, and thus the production yield. Using the program 3D- 
Block Expert, the volume of blocks extracted in a sector of a quarry taking can be predicted, when taking into account the joint distribution and geometry.
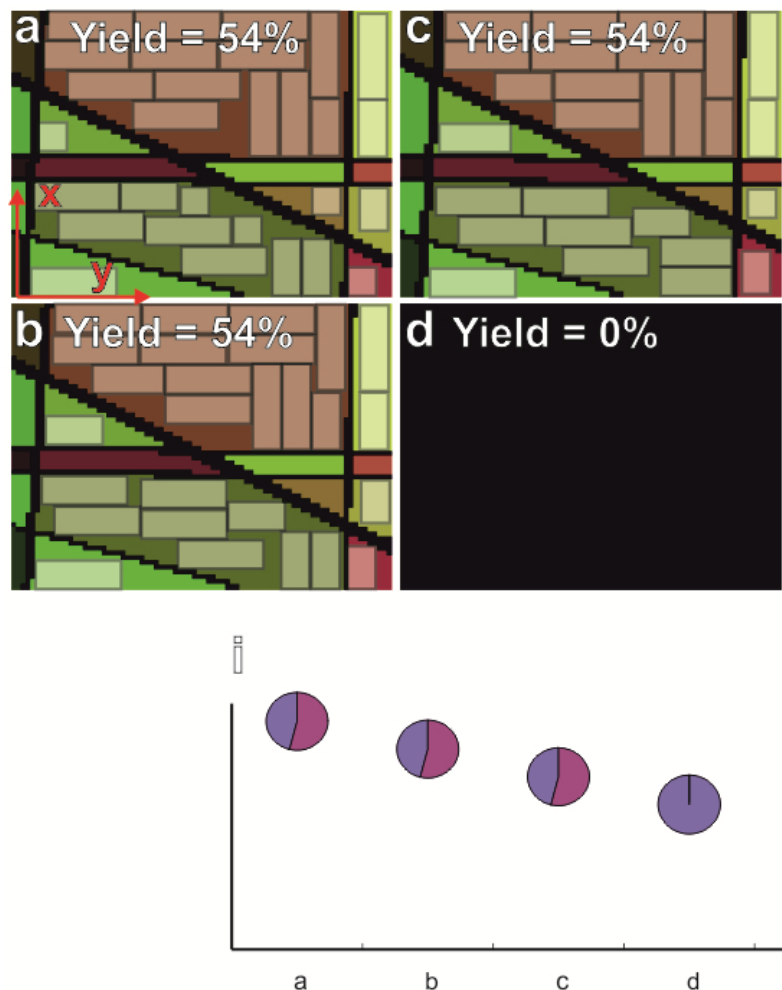

d Yield $=0 \%$
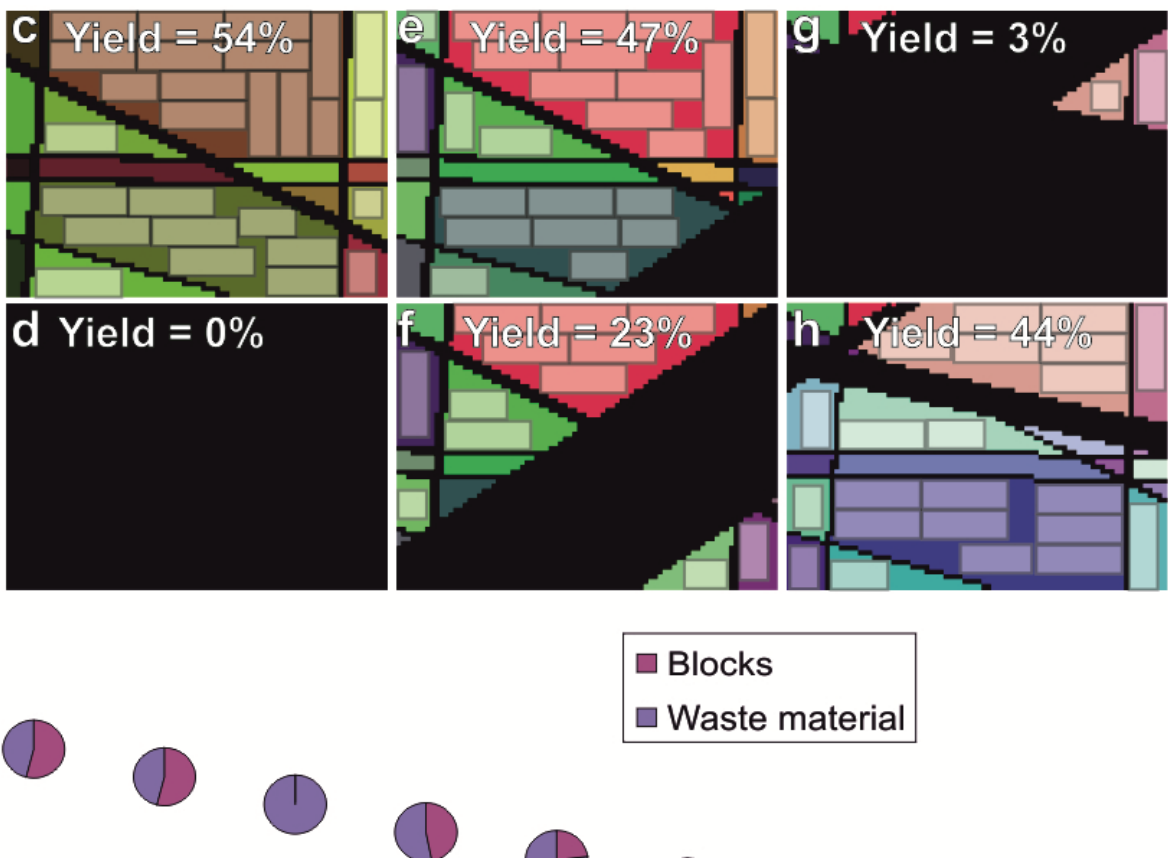

Fig. 2.31: Possible block size distribution for the Black Stone Quarry section using 3D Block Expert (each slab is one meter thick): a. First slab from top to bottom of the block; b. Second slab, etc. The black zones seen in d.; f. and g. represent waste material; i. Pie diagrams showing the yield of each model section.

\subsubsection{Estimation of the dolerite resources}

The total quantity of dolerite dikes in the Piedra Alta Terrane is difficult to estimate. The available information can be used to estimate a maximum and minimum amount of extractable dolerites.

According to Bossi and Campal (1991), the number of dikes is around 300 and their average length and width is 460 and $20 \mathrm{~m}$, respectively. The minimum value is based on observations published by Spoturno et al (2004) for the San José Department, where they found a total of 11 dikes in an area of $2,500 \mathrm{~km}^{2}$. If a similar dike distribution is assumed for the rest of the area where the dikes crop out, a total of 88 dikes may exist. The current investigation indicates that there are about 19 dolerite 
quarries, where four of them have been superficially mined and five of them are still in operation.

The geometry for this type of deposit is simplified to that of a cuboid or parallelepiped, where the width of the dike is "a", the length is " $b$ " and the depth of the dike is " $c$ ". The volume can be calculated by $V=a{ }^{*} b{ }^{*} c$. To calculate the reserves of dolerites in the Piedra Alta Terrane, an average dike is considered to have a width of 30 meters, a length of $150 \mathrm{~m}$ and a maximum exploitation depth of 50 $\mathrm{m}$. The total volume of this average deposit is $225,000 \mathrm{~m}^{3}$. Considering that 19 productive dikes at different stages of mining have already been identified in Uruguay, the volume of the reserve base is $4,275,000 \mathrm{~m}^{3}$. The efficiency of extraction for commercial blocks is not better than 10\% (Oyhantçabal et al, 2007a) and that 20,310 $\mathrm{m}^{3}$ were already extracted (Bossi and Campal, 1991; Morales Pérez, 2004; DINAMIGE, 2010), a volume of probable reserves of at least 407,500 $\mathrm{m}^{3}$ can be suggested. From this volume around $10 \%$ of the rock has the quality of Absolute Black.

Comparable dolerite quarries to those in Uruguay can be found in Sweden. At present there are seven quarries in Sweden where each of them produces an average of $8,000 \mathrm{~m}^{3}$ of stone per year (Swedish Geological Survey, 2009). In comparison to Sweden, the production in Uruguay is very low. In the last several years the production ranged from 4,000 to 5,000 tons/year for the five quarries active in the country. This comparison indicates the production in Uruguay can be increased several times, provided that an adequate exploration strategy is followed. 
Case study: Dolerites

\section{Appendix}

Table A.2.1: Petrophysical properties: density, porosity, water absorption (W.A.).

\begin{tabular}{|c|c|c|c|c|c|c|c|c|c|c|}
\hline Rock/Test & ID & $\begin{array}{c}\text { Bulk } \\
\text { density } \\
\left(\mathbf{g} / \mathrm{cm}^{3}\right)\end{array}$ & $\begin{array}{c}\text { Matrix } \\
\text { density } \\
\left(\mathbf{g} / \mathrm{cm}^{3}\right)\end{array}$ & $\begin{array}{c}\text { Porosity } \\
(\%)\end{array}$ & $\begin{array}{c}\text { Average } \\
\text { pore } \\
\text { radii } \\
(\mu \mathrm{m})\end{array}$ & $\begin{array}{c}\text { Most } \\
\text { abundant } \\
\text { pore radii } \\
(\mu \mathrm{m})\end{array}$ & $\begin{array}{l}\text { Capilarry } \\
\text { W.A. } \\
\left(\mathrm{kg} / \mathrm{m}^{2} \mathrm{~h}^{0.5}\right)\end{array}$ & $\begin{array}{c}\text { Forced } \\
\text { W.A. } \\
\text { (wt\%) }\end{array}$ & $\begin{array}{l}\text { Unforced } \\
\text { W.A. } \\
\text { (wt\%) }\end{array}$ & S-value \\
\hline Absolute Black Dolerite & U11A & 2.99 & 2.99 & 0.03 & 0.097 & 0.013 & 0.04 & 0.01 & 0.01 & 0.96 \\
\hline Moderate Black Dolerite & U110 & 3.02 & 3.02 & 0.06 & 0.064 & 0.021 & 0.09 & 0.02 & 0.02 & 0.97 \\
\hline Oriental (Pimafox) Dolerite & U66 & 2.97 & 2.98 & 0.12 & 0.209 & 0.084 & 0.13 & 0.04 & 0.03 & 0.87 \\
\hline
\end{tabular}

Table A.2.2: Petrophysical properties: thermal expansion, water vapor diffusion and ultrasound.

\begin{tabular}{|c|c|c|c|c|c|c|c|c|c|c|c|c|}
\hline \multirow{2}{*}{$\begin{array}{l}\text { Rock/Test } \\
\text { Direction }\end{array}$} & \multirow{2}{*}{ ID } & \multicolumn{5}{|c|}{ Thermal Expansion $\left(10^{-6} \mathrm{~K}^{-1}\right)$} & \multicolumn{3}{|c|}{$\begin{array}{l}\text { Water vapor } \\
\text { diffusion }\end{array}$} & \multicolumn{3}{|c|}{ Ultrasound (km/s) } \\
\hline & & $x$ & y & $\mathbf{z}$ & $\begin{array}{l}\text { Average } \\
\text { Value }\end{array}$ & $\begin{array}{l}\text { Anisotropy } \\
\text { (\%) }\end{array}$ & $\mathbf{x}$ & y & $\mathbf{z}$ & $\mathbf{x}$ & y & $\mathbf{z}$ \\
\hline Absolute Black Dolerite & U11A & 6.66 & 6.79 & 6.68 & 6.71 & 2 & 8487 & 6069 & 5583 & 5.84 & 5.72 & 5.92 \\
\hline Moderate Black Dolerite & U110 & 6.53 & 6.55 & 6.87 & 6.65 & 5 & 5344 & 5473 & 5599 & 6.41 & 6.49 & 6.34 \\
\hline Oriental (Pimafox) Dolerite & U66 & 5.67 & 5.87 & 5.80 & 5.78 & 2 & 120 & 809 & 1130 & 5.84 & 5.58 & 5.61 \\
\hline
\end{tabular}

Table A.2.3: Petrophysical properties: uniaxial compressive strength, modulus of elasticity and indirect tensile strength.

\begin{tabular}{|c|c|c|c|c|c|c|c|c|c|}
\hline \multirow{2}{*}{$\begin{array}{l}\text { Rock/Test } \\
\text { Direction }\end{array}$} & \multirow[t]{2}{*}{ ID } & \multicolumn{2}{|c|}{$\begin{array}{l}\text { Uniaxial Compressive } \\
\text { Strength (MPa) }\end{array}$} & \multicolumn{3}{|c|}{ Modulus of elasticity (GPa) } & \multicolumn{3}{|c|}{$\begin{array}{l}\text { Indirect Tensile Strength } \\
\text { (MPa) }\end{array}$} \\
\hline & & $\mathbf{x}$ & $y \quad z$ & $\mathbf{x}$ & $\mathbf{y}$ & $\mathbf{z}$ & $\mathbf{x}$ & $\mathbf{y}$ & z \\
\hline Absolute Black Dolerite & U11A & $400 \pm 34$ & $371 \pm 37367 \pm 16$ & $32.9 \pm 7.4$ & $29.6 \pm 9.9$ & $30.6 \pm 11.9$ & $16.7 \pm 4.5$ & $19.5 \pm 4.3$ & $17.5 \pm 5.8$ \\
\hline Moderate Black Dolerite & U110 & $266 \pm 27$ & $269 \pm 38275 \pm 25$ & $27.3 \pm 15.8$ & $22.9 \pm 7.3$ & $17.4 \pm 4.5$ & $16.7 \pm 3.0$ & $15.9 \pm 3.0$ & $14.3 \pm 3.4$ \\
\hline Oriental (Pimafox) Dolerite & U66 & $308 \pm 39$ & $260 \pm 29285 \pm 41$ & $29.2 \pm 16.0$ & $15.4 \pm 6.3$ & $15.0 \pm 6.1$ & $14.7 \pm 3.2$ & $14.4 \pm 2.9$ & $14.3 \pm 2.7$ \\
\hline
\end{tabular}

Table A.2.4: Petrophysical properties: flexural strength, abrasion strength and breaking load at the

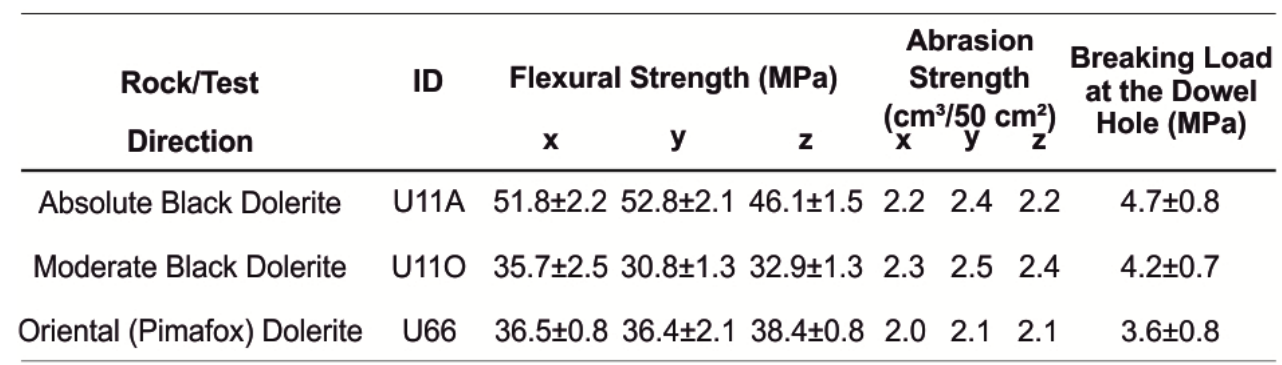




\section{Case study: Granitoids and syenitoids}

\section{Abstract}

In Uruguay commercial granite varieties consist of mafic rocks, granitoids and syenitoids. There is a long tradition of using dimensional stones in architecture and art. Some of the present applications of these dimensional stones are as façade cladding, countertops and outdoor and indoor floor slabs. The color spectrum varies from black to light gray, covering a wide variety of red and pink and minor greenishgray. The décor of these granitic dimensional stones is mainly determined by their fabric, fundamentally the grain size and the color distribution between the different minerals that compose the rocks. In the present research the most important commercial granites were sampled in order to analyze their petrography and petrophysical properties. A detailed structural analysis has been performed in several deposits, as well as the application of the software 3D Block Expert for modeling the possible raw block size distribution. Other factors controlling the mining viability of the deposits were also studied (e.g. homogeneity/heterogeneity of color and décor) and the possible reserves were calculated.

\subsection{Introduction}

Granitic dimensional stones are widely used in architecture. Some examples include paving tiles, monuments, interior and exterior wall cladding (Montani, 2008) (Fig. 3.1 and 3.2). Its share of the market of dimensional stones has doubled in the period between 1995 and 2007 (Montani, 2008). Due to their durability, granite represents one of the preferred natural materials when deterioration risk is present.

Commercially, the term granite is used for dimension stones consisting of all the hard rocks, even when their lithology strongly differs from that of true granite. In the Earth Sciences, the use is stricter and the name granite only applies to a plutonic rock containing quartz, alkali feldspar and plagioclase. These rocks plot in a specific field defined by the QAPF classification triangle (Streckeisen, 1976).

Granitoid is a superordinate category designating a plutonic rock that has between 20 and 60 percent quartz in the QAPF classification (Streckeisen, 1976; Le Maitre et 
al, 2002; Allaby and Allaby, 1990; Jackson, 1997). It includes the alkali feldspar granites, granites sensu stricto, granodiorites and tonalites. Syenitoid is a term used for plutonic rocks with a quartz content ranging between 0 and $20 \%$ and a feldspar ratio (alkali feldspar/plagioclase + alkali feldspar) between 35 and $100 \%$ (Streckeisen, 1976; Le Maitre et al, 2002; Allaby and Allaby, 1990; Jackson, 1997). Gabbroids include all the plutonic rocks showing a feldspar ratio between 0 and $35 \%$ and quartz contents between 0 and 20\% (Streckeisen, 1976; Le Maitre et al, 2002; Allaby and Allaby, 1990; Jackson, 1997). Mafic rock is a term that includes gabbroids but also other igneous rocks (e.g. basalt) composed chiefly by mafic minerals (Jackson, 1997).

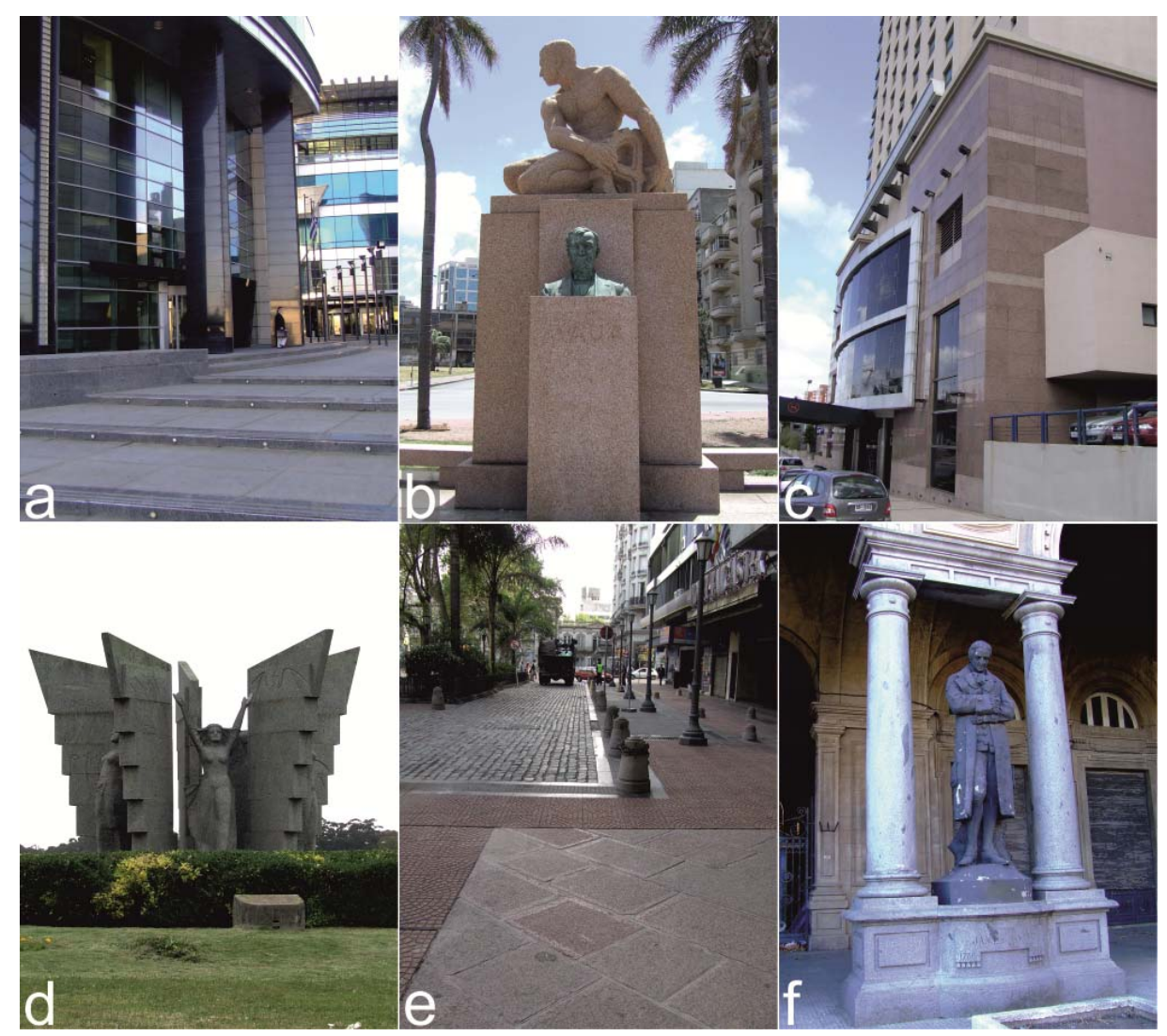

Fig. 3.1: Uses of Uruguayan commercial granites in the city of Montevideo: a. Outdoor façade cladding using Moderate Black Dolerite and flooring slabs using Cufré Granite in the Antel Tower; $\mathbf{b}$.

Outdoor sculpture (Vizconde de Mauá) using La Paz Granite, c. Outdoor façade cladding using polished and unpolished slabs of Violeta Imperial Syenite; d. Outdoor sculpture using Moskart Granite; e. Different sorts of outdoor flooring slabs using red granites; f. Outdoor socle and columns using Isla Mala Tonalite in the Central Train Station (Estación Central AFE).

At the beginning of the 21st century, the European countries decided that dimensional rocks must be correctly named according to the petrological description and the standards of international geological terminology (e.g. EN 12407, EN 12440, 
EN 12670). Outside Europe the American standards are normally used (e.g. ASTM C119). These standards allow the naming of granite as granular igneous rocks, which includes granitoids, syenitoids and mafic rocks (gabbros, dolerites), but also some granular metamorphic rocks such as gneisses and schists (Quick, 2002).
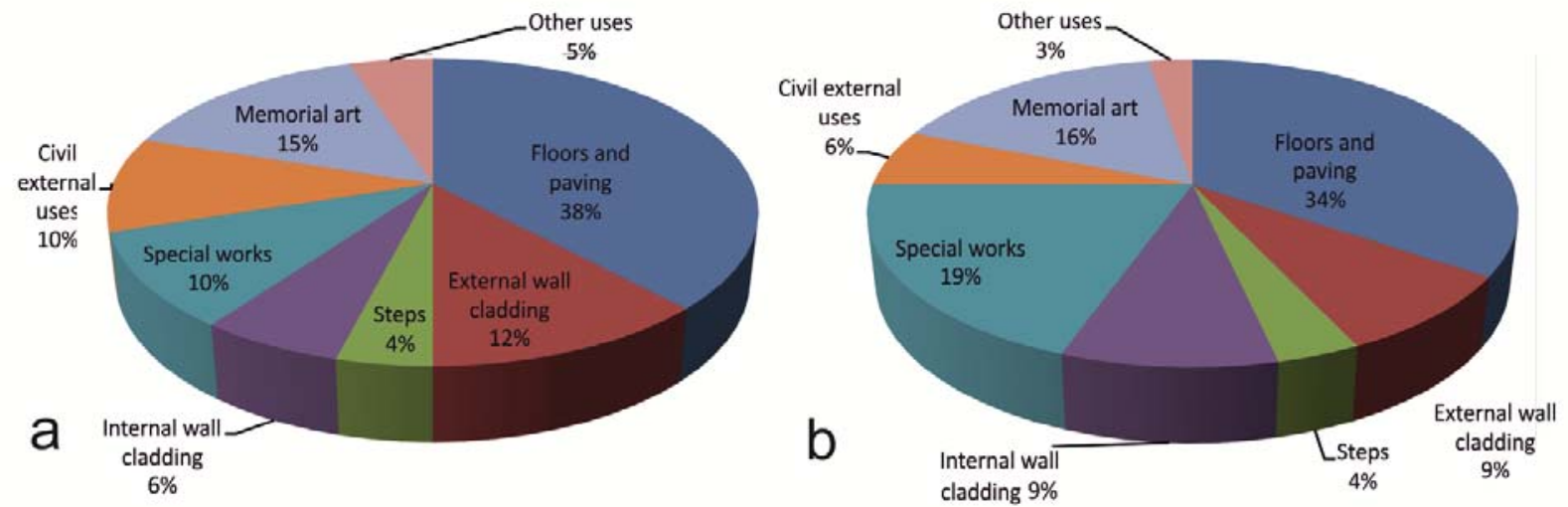

Fig. 3.2: Global main uses of dimensional stones (in percentage) after Montani (2008): a. Global uses in 1995 (total finished production: 25 million tons); b. Global uses in 2007 (61 million tons).

In Uruguay, what is commercially known as "granite" includes a wide variety of lithologies such as granitoids (granodiorite, tonalite, granite s.s.), syenitoids (quartz syenite, alkali feldspar syenite and quartz alkali feldspar syenite) and mafic rocks (gabbro-norite and dolerite) (Table 4.1). The colored commercial granites include syenitoids and granites s.s., whereas the gray granites comprise granites s.s., granodiorites and tonalites. The rocks that are commercially known as black granites are basically dolerites and gabbro-norites.

The mining of dimensional stones in Uruguay began during the first settlements with the construction of fortifications and citadels between the end of the $17^{\text {th }}$ and the beginning of the $18^{\text {th }}$ centuries. Examples are the fortress of Santa Teresa, built from the porphyritic facies of the Santa Teresa Granite and the citadels of Colonia del Sacramento and Montevideo constructed from local granitic and metamorphic rocks. Since the beginning of the $20^{\text {th }}$ century until today, commercial granites have been used for a wide variety of architectural and artistic purposes. 
The dimensional stone sector had a very important productive phase at the beginning of the $20^{\text {th }}$ century. Syenitoids of the Pan de Azúcar-Piriápolis area and granites of La Paz provided material for the construction of the most important cities of the region, especially for Montevideo and the neighboring city of Buenos Aires.

Table 3.1: List of commercial granites from Uruguay (data source: Bossi and Navarro, 2000; DINAMIGE, 2011; Comunità Economica Europea, no date; author's database).

\begin{tabular}{|c|c|c|c|c|c|}
\hline Rock & Id & Commercial Type & Commercial Name & Locality & Department \\
\hline Dolerite & U8 & Black Granite & Sacramento (Comercio Exterior S.A.) & $\mathrm{A}^{\circ}$ Pichinango & Colonia \\
\hline Dolerite & U11A & Black Granite & Absolute (Black Stone S.A.) & $A^{\circ}$ de la Quinta & San José \\
\hline Dolerite & U110 & Black Granite & Moderate or Oriental (Black Stone S.A.) & $\mathrm{A}^{\circ}$ de la Quinta & San José \\
\hline Dolerite & U66 & Black Granite & Oriental (Pimafox) & $\mathrm{A}^{\circ}$ Polonia & Colonia \\
\hline Gabbro/norite & U87 & Black Granite & Mahoma Black & Mal Abrigo & San José \\
\hline Basalt & U49 & Black Granite & Arapey Black & Arroyo Valentín Chico & Salto \\
\hline Granite & $\mathrm{U} 2$ & Gray Granite & Maldonado Gray & Maldonado & Maldonado \\
\hline Granodiorite & U4 & Gray Granite & Chamangá Gray & Arroyo Chamangá & Flores \\
\hline Granite & U53 & Gray Granite & Cuchilla del Perdido Gray Blue & Chuchilla del Perdido & Soriano \\
\hline Granite & U70 & Gray Granite & Cerro Áspero or Gray Rocha & Arroyo Sauce de Rocha & Rocha \\
\hline Granite & U73 & Gray Granite & Cufré Gray Blue & Cufré & onia \\
\hline Granite & U80 & Gray Granite & Cerro de Carmelo Gray & El Cerro, Carmelo & nia \\
\hline Granite & U81 & & Ismael Cortinas Gray & Ismael Cortinas & \\
\hline Granite & U82 & Gray Granite & Loyner Gray & & Flores \\
\hline Granite & U83 & Gray Granite & Goñi Gray & Goñi & rida \\
\hline Granite & U85 & Gray Granite & Iguazú or Garzón Gray & Garzón & Rocha \\
\hline Granite & U89 & Gray Granite & Losten Gray & & Soriano \\
\hline Granite & U90 & ranite & & Cuchilla de Dionisio & Treinta y Tres \\
\hline & U93 & Gray Granite & Santa Ter & Santa Teresa & Rocha \\
\hline Tonalite & U94 & Gray Granite & Isla Mala Gray & 25 de Agosto & Florida \\
\hline nite & U95 & Gray Granite & Northern Garzón Gray & Garzón & Maldonado \\
\hline & U7 & Dark green Granite & Labradorita Oriental or Moskart & Soca & Canelones \\
\hline Granite & U74 & Red Granite & Caramel Pink or La Paz & La Paz & Canelones \\
\hline Granite & U75 & Red Granite & Asperezas & $\mathrm{A}^{\circ}$ Ásperezas - $\mathrm{A}^{\circ}$ Malo & Cerro Largo \\
\hline Granite & U76 & Red Granite & Guazunambí, Montevideo or Iguazú & Arbolito & Cerro Largo \\
\hline Granite & U77 & Red Granite & Luján or Santa Clara & Santa Clara del Olimar & Cerro Largo \\
\hline Granite & U84 & Red Granite & & & Lavalleja \\
\hline Granite & U88 & Red Granite & Mahoma Red & Mal Abrigo & San José \\
\hline Quartz alkali feldspar syenite & U15 & Red Granite & Salmon Red or Guazubirá & Sierra de Animas & Maldonado \\
\hline Alkali feldspar syenite & U46 & Red Granite & Artigas Pearl or Artigas & Piriápolis & Maldonado \\
\hline Quartz-syenite & U47 & Red Granite & Violeta Imperial & Sierra de Ánimas & Maldonado \\
\hline Quartz alkali feldspar syenite & U92 & Gray Granite & Pan de Azúcar White & Piriápolis & Maldonado \\
\hline
\end{tabular}

The international trend of using commercial granites mainly for decorative purposes and not for structural ones is a practice used by the architects and construction companies in Uruguay. Commercial granite is use in Uruguay for façade cladding, as paving tiles, for interior floor and wall cladding, countertops, stairs, columns, sculptures, monuments and precision tables, among other applications (Fig. 3.1).

Similar investigations on granitic dimensional stones in Thailand were carried out by Hoffman (2006), Hoffmann and Siegesmund (2007), in Argentina by Mosch et al (2007) and in Uruguay by Morales Pérez and Muzio (2005) and Oyhantçabal et al (2007a). Some examples of detailed research in exotic granitic rocks included an 
investigation on the larvikites of Norway (Heldal et al, 2008), on dolerites from Uruguay (Morales Demarco et al, 2011) and on a granitic batholith in São Paulo, Brazil (Artur et al, 2001).

The dimensional stone market is particularly sensitive to fashion trends and economic constrains. Beginning in the year 2000 the economic crisis in South America led to a severe decline in the construction industry, and thus, in the dimensional stone production.

Uruguay has a wide variety of dimensional stones in terms of color and décor, however, their occurrence has not been sufficiently studied. The present study aims to contribute to the economic geological development of the granitic dimensional stones of Uruguay with respect to further exploration, evaluation, mining and marketing.

Another important goal of the present study is to evaluate the petrophysical properties of the different granitic dimensional stones of Uruguay in order to determine the best potential uses of these rocks. Furthermore, the deposits are characterized according to color and décor, so that the distribution of commercially interesting stones can be determined as well as the factors controlling the deposits. These factors are the volume of the deposit, the lithological aspects and the structural elements present. To provide a steady product for the market the volume of material available is important. However, the waste material is also of secondary economic value in the operation of dimensional stone deposit. Structural elements control the deposit by the joint system present, whereby their distribution determines the shape and volume of the blocks being mined. Lithological aspects define the suitability of a granitic rock for use as a dimensional stone, since it controls the color and décor. The mineral composition and fabric are important for the characterization of a dimensional stone with respect to the petrophysical properties of the rock, as well as its resistance to weathering.

The economic geological evaluation of dimensional stone deposits essentially relies on two factors (e.g. Peschel, 1977; Singewald, 1992): i. the presumable occurrence 
of raw blocks (referring to the proportion of raw blocks suitable for industrial processing) and ii. the petrophysical properties (tested according to EN norms), which provide information about the rock behavior under the influence of deterioration forces.

The production of raw blocks of adequate sizes is a major factor in the economic evaluation of a deposit. An optimal block size is required for economical processing using modern cutting techniques (e.g. a minimum block size of 2.5 * 1.3 * $1 \mathrm{~m}$ is necessary when using the gang saw blade). This optimal size must also take into account the associated processing losses (e.g. oddments). This is essentially controlled by the structural elements (e.g. the spatial distribution of joint systems and their frequency) and the homogeneity of the rock deposit. Currently, no models exist for sustainable mining of these types of deposits, which reduces the waste material generated when producing an optimal block size.

\section{Production}

The world production of all types of dimensional stone in 2007 was 103 million tons (Montani, 2008). The leading productive countries in that year were China, India, Turkey, Italy and Spain, which together produced almost $60 \%$ of the dimensional stone (Montani, 2008). In 2007 Latin America produced 6.5 million tons, with Brazil being the main producing country with 5.75 million tons, followed by Argentina with 0.35 million (Montani, 2008). Uruguayan production in the same year was of 7,048 tons (Dinamige, 2008), just $0.11 \%$ of the total Latin American production.

The most important countries in the granitic dimensional stone sector are China, India, Spain and Portugal as illustrated in Figure 3.3, where the dimensional and granitic stone production in million tons is shown. The importance of granitic rocks in this production is visible Figure 3.4 , where the total dimensional stone production is divided into three main stone varieties: commercial granites, marble and travertine, and slate and others. Worldwide production of commercial granites has almost quadruplicated in 82 years (Montani, 2008). 


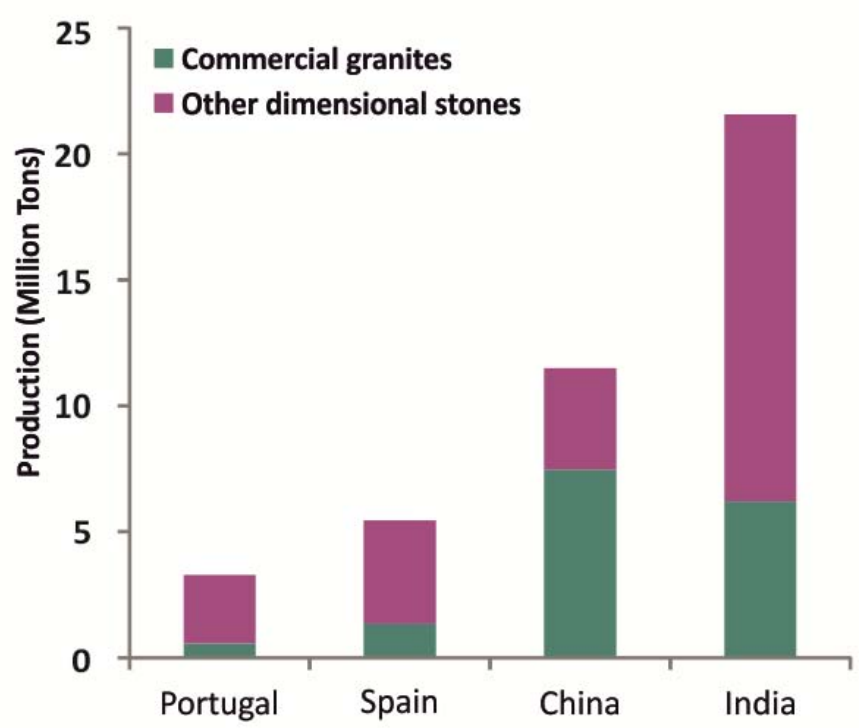

Fig. 3.3: Examples of dimensional stone production in million tons for the year 2001 (Sources: Spain: Federación Española de la Piedra Natural; 2008; India: Centre for Development of Stones - Jaipur; 2011; Portugal: Direção Geral de Energia e Geologia, 2011; China: Jorge Quiroz C Consultores Asociados, 2006).

The production of dimensional stone in Uruguay today is mainly represented by granite, slates and sandstone with a marginal proportion of marble (Fig. 3.5). The most important variety in the commercial production of granite is the black granite (dolerite), mainly the Moderate Black variety. To gain a better idea of the importance of each commercial variety, the production (in $\mathrm{m}^{3}$ ) was calculated using the original data in tons from Dinamige (2008) for the year 2007 and the density values obtained in this research. Dolerites showed a production of $1,810 \mathrm{~m}^{3}$, representing $81 \%$ of the commercial granite production, gray granites represent $10 \%$, greenish-gray granite $5 \%$ (Soca or Moskart) and pink granite 4\% (La Paz or Caramel Pink).
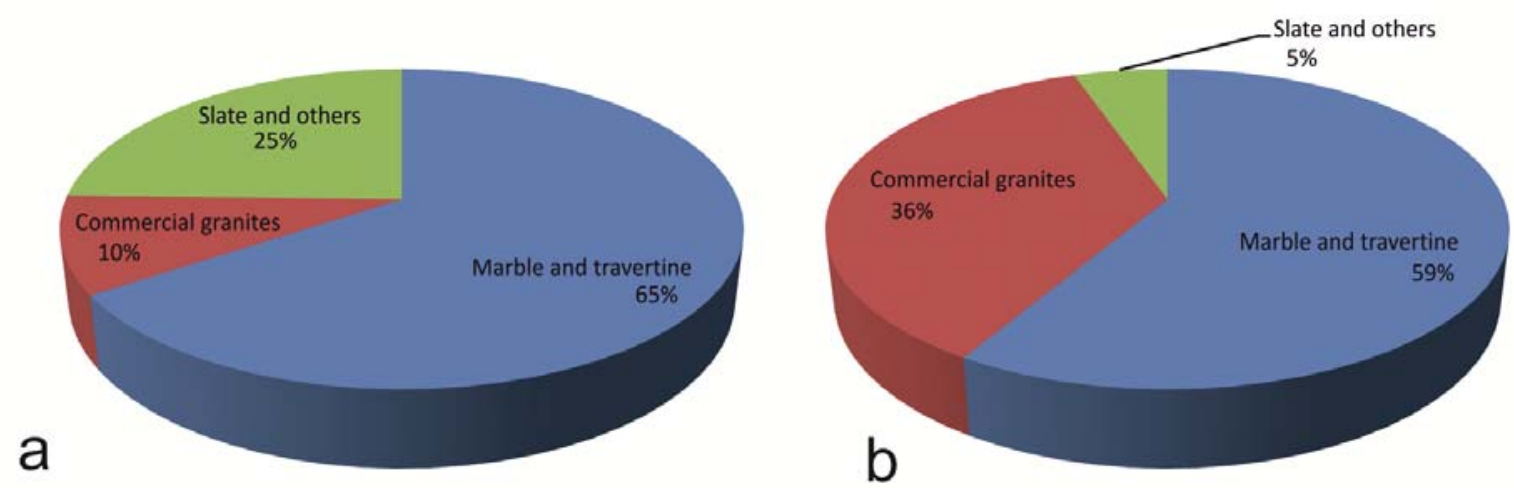

Fig. 3.4: World dimensional stone production classified by rock type (in percentage): a. Production in 1926 (total production is 1.79 million tons); b. Production in 2007 (total production is 103.5 million tons) (data source Montani, 2008). 


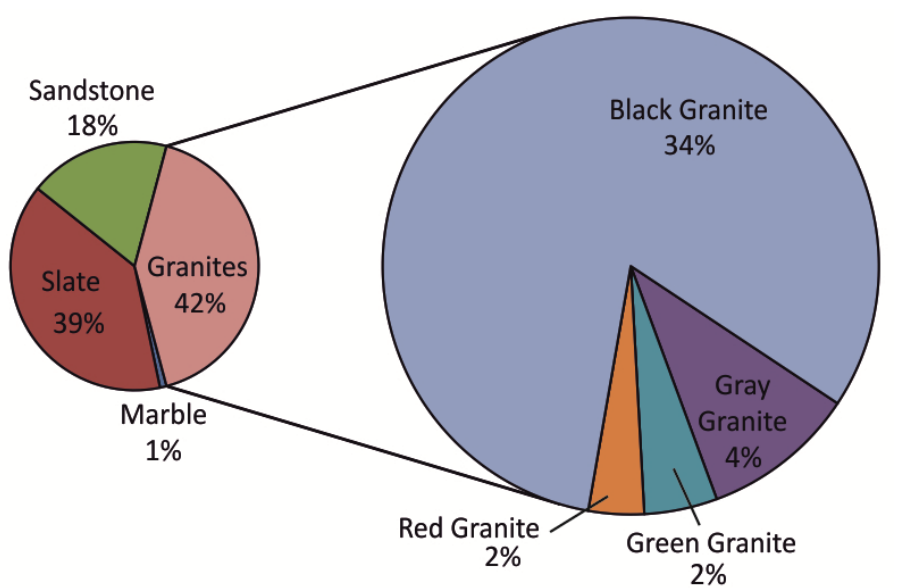

Fig. 3.5: Production of dimensional stone in Uruguay in 2007 (in percentage) (total production is 5,322 $\mathrm{m}^{3}$ ) (data source: DINAMIGE, 2008).

\subsection{Geological setting}

Uruguayan geology is characterized by an igneous-metamorphic basement and several basins distributed in different regions of the country (Fig 3.6). The crystalline basement was originally divided into two domains by Ferrando and Fernández (1971), the western domains belonging to the Transamazonian Cycle (Paleoproteozoic) and the eastern one to the Brasiliano Cycle (Neoproterozoic).

Today the western domain is known as Rio de la Plata Craton (Almeida, 1973; Bossi and Ferrando, 2001; Oyhantçabal et al, 2010), which extends westwards into Argentina. The eastern domain is divided into the Nico Pérez and Punta del Este Terranes (Bossi and Ferrando, 2001; Oyhantçabal et al, 2010). A mobile belt known as the Dom Feliciano Belt is located between these two terranes (Fragoso-Cesar, 1980; Oyhantçabal et al, 2009; 2010). The boundaries between these tectonostratigraphic units are from west to east: the Sarandí del Yí Shear Zone (SYSZ) and Sierra Ballena Shear Zone (SBSZ).

Since the Neoproterozoic the Uruguayan continental area was quite stable, but was interrupted in the Lower Cretaceous by the opening of the South Atlantic Ocean. In this major event, rift basins with associated bimodal magmatism opened and flood basalts were deposited over a wide area of South America, known as the Paraná Basin, which also includes northwestern Uruguay. 


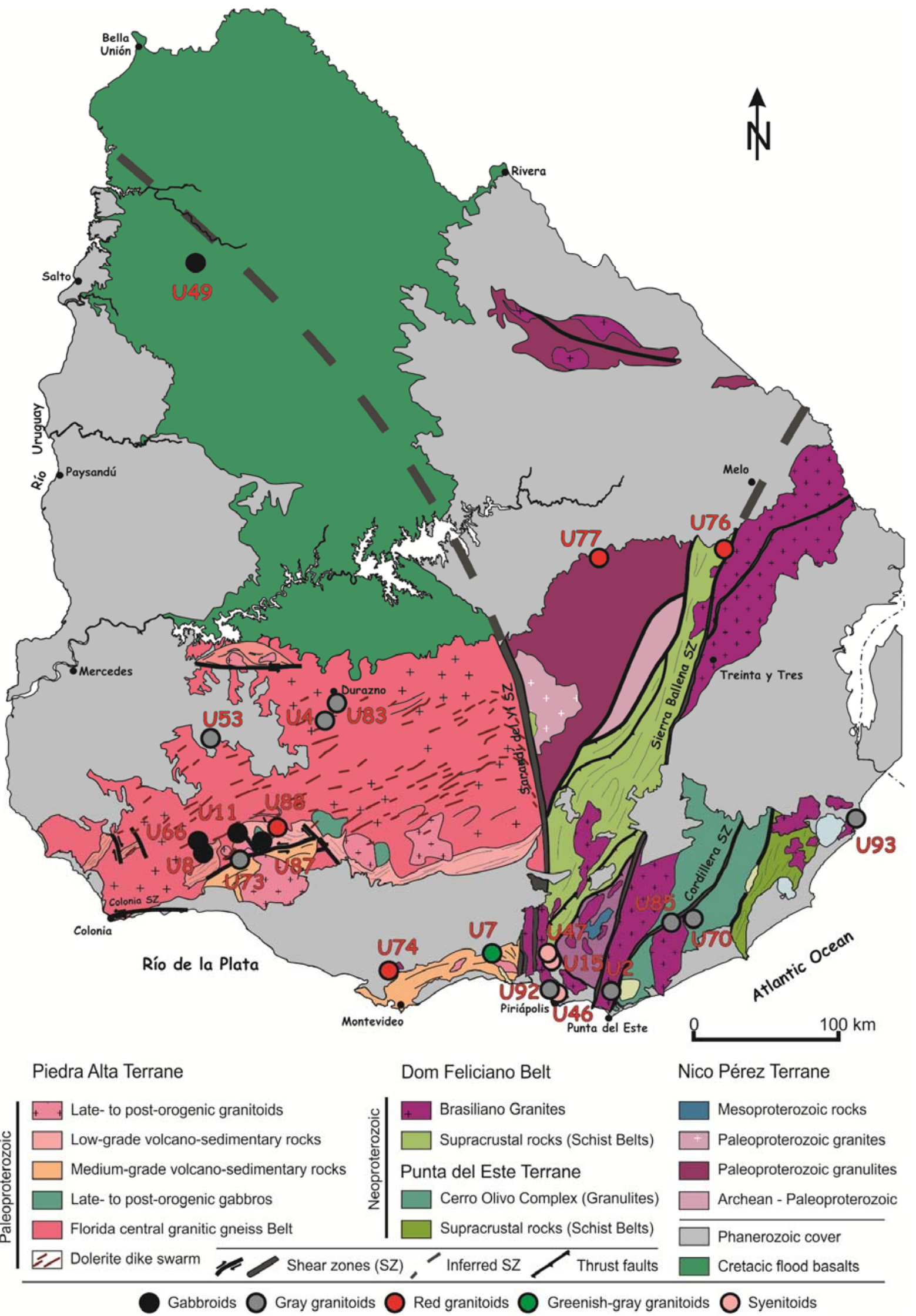

Fig. 3.6: Geological map of Uruguay with deposit localities (redrawn after Oyhantçabal et al, 2010 and Sánchez Bettucci et al, 2010). 


\subsection{Regionalization of commercial granite deposits}

The commercial granite deposits found in Uruguay occur in three tectonostratigraphic units: the Río de la Plata Craton (RPC), the Dom Feliciano Belt (DFB) and the Punta del Este Terrane (PET) (Fig. 3.6). The main tectonic events did not negatively affect the petrophysical properties and the possibility of mining these intrusive rocks. Exceptions can be found locally in some deposits, where a brittle regime developed cataclastic zones were no mining can take place.

In the RPC, a dolerite dike swarm crops out in an area of $20,000 \mathrm{~km}^{2}$ (Bossi and Campal, 1991; Morales Demarco et al, 2011). The mined dolerite is commercialized as high quality black granite consisting of two varieties, based on the intensity of their black color: Absolute Black and Moderate Black (Fig. 3.7a and b; Coronel et al, 1987; Bossi and Campal, 1991 and Morales Demarco et al, 2011). Absolute Black is mined from dikes that have a fine-grained zone wide enough to produce marketable blocks. Two other mafic rocks with increasing importance are also located in the Piedra Alta Terrane (PAT): the gabbro-norite known as Mahoma Black belonging to the Guaycurú Complex (Bossi and Schipilov, 2007) and the Arapey Basalt, belonging to the Arapey Group. This group is composed of six different lithostratigraphic units (formations), each one interbedded with several lava flows that show variations in the geochemical and mineralogical composition (Bossi and Schipilov, 2007).

Since the Paleoproterozoic the Rio de la Plata craton remained relatively stable tectonically, with no indication of deformational events or moderate ones. Evidence of high-grade metamorphic overprinting in the intrusions is absent. Thus, the extraction of commercial granites in this craton, due to the lack of these structural elements, makes mining possible.

Gray granites, tonalites and granodiorites are very common in this craton. Some examples of commercial gray granitoids are the Chamangá Gray, Goñi Gray and the Cuchilla del Perdido Gray Blue (Fig. 3.7c). Cufré Gray Blue (Fig. 3.7f) has a moderate foliation not only determined by the biotite (Preciozzi et al, 1985), but also by the alignment of the mafic enclaves. Caramel Pink (Fig. 3.7i) is the porphyritic facies of the La Paz Granite (Preciozzi et al, 1985; Oyhantçabal et al, 1990a) and 
together with the Mahoma Red and Moskart (Fig. 3.7d), they illustrate examples of colored granites s.s. in this unit.

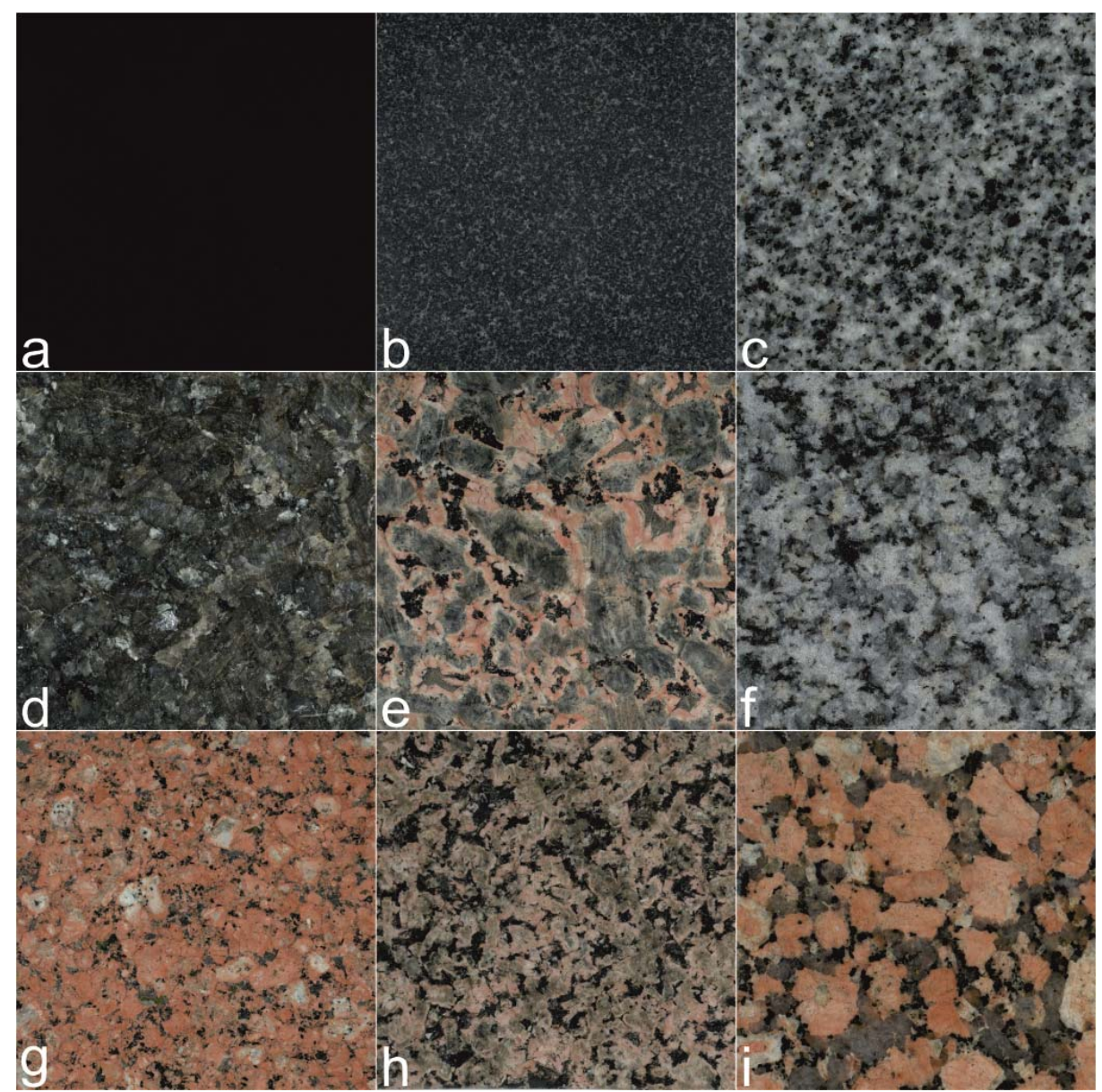

Fig. 3.7: Polished slabs of Uruguayan commercial granites (slab length $=10 \mathrm{~cm}$ ): a. Absolute Black Dolerite; b. Moderate Black Dolerite; c. Cuchilla del Pérdido Gray Granite; d. Moskart Granite;

e. Artigas Pearl Syenite; f. Cufré Gray Granite; g. Salmon Red Syenite; h. Violeta Imperial Syenite; i. Caramel Pink Granite.

Most of the dimensional stone deposits in Uruguay are located in the DFB and many of them are granitic rocks. Syenitoid deposits, for example, are located in the Sierra de Ánimas Complex (Coronel et al, 1987; Bossi and Navarro, 2001; Morales Pérez, 2004; Oyhantçabal et al, 2007a). The commercial varieties Artigas Pearl (Fig. 3.7e) and Pan de Azúcar White are located in the southernmost portion of this complex (see Fig. 3.6), whereas the Salmon Red (Fig. 3.7g) and the Violeta Imperial (Fig. 3.7h) are in the central part. These commercial varieties are characterized by their light red, pink, violet and gray colors. 
Deposits of the Luján or Santa Clara Granite are located in the central part of the DFB (Preciozzi et al, 1985; Bossi and Navarro, 2000; Bossi and Ferrando, 2001; Morales Pérez, 2004). Associated with the Sierra Ballena Shear Zone (SBSZ) are deformed gray granite deposits. Maldonado Gray is one of these granites, which shows the most developed features of synmagmatic deformation of all the commercial granites analyzed, having a very well-developed foliation and mineral lineation. The Guazunambí Granite is a red granite located further to the north in the DFB (see Fig. 3.6), (Preciozzi et al, 1985; Bossi and Navarro, 2000; Bossi and Ferrando, 2001; Morales Pérez, 2004). The rock shows a gentle foliation since this region experienced a progressive deformation towards the SBSZ.

In the PET only gray granite deposits have been mined. Some of them are fine grained like the Cerro Áspero and Garzón granites (Preciozzi et al, 1985). Moreover, very coarse-grained granites showing oriented alkali-feldspar phenocrysts occur (Preciozzi et al, 1985; Muzio and Artur, 1999), and these are known as the Santa Teresa Gray.

\subsection{Lithological inventory}

Previous authors have studied the granitic rocks of Uruguay that are used as dimensional stones by paying special attention to the dolerites, syenitoids, greenishgray granites, and some of the red and gray granites (Scheer, 1964; Caruso, 1987; Bossi and Navarro, 2001; Morales Pérez, 2004; Spoturno et al, 2004a; b; c; Techera et al, 2004a; b; c). The different commercial granites of Uruguay are classified according to their mineralogical and geochemical composition into mafic rocks, granitoids and syenitoids. In Figure 3.8 the modal composition of the commercial granites is plotted using the QAP diagram proposed by Streckeisen (1976). In Figure 3.9a the geochemical analyses are plotted in the R1-R2 diagram (De La Roche et al, 1980 ) and in Figure 3.9b in the TAS diagram (Middlemost, 1997; Best, 2003). Table 3.2 and 3.3 shows the geochemical analyses for the commercial granite varieties. 


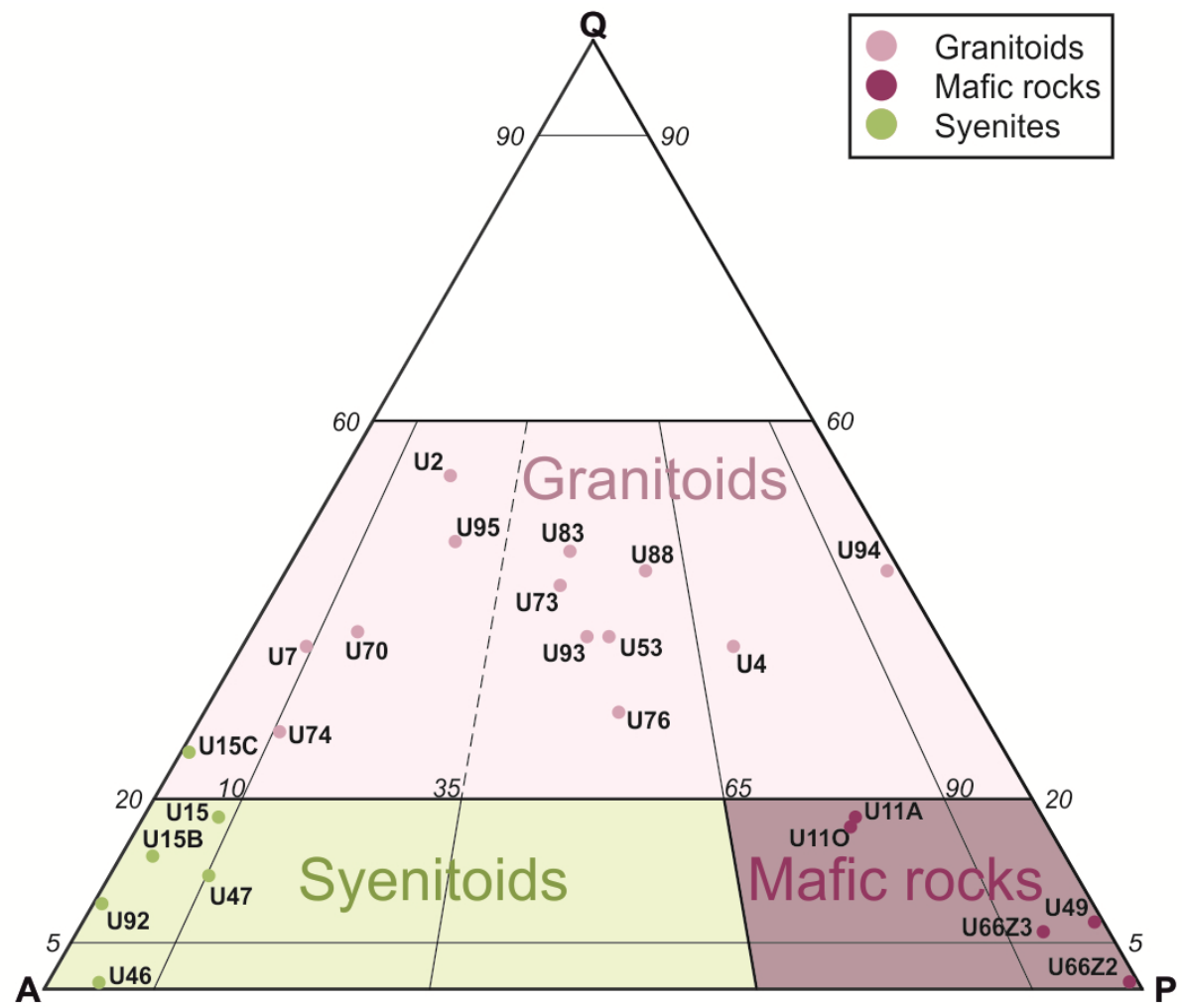

Fig. 3.8: QAP diagram of Uruguayan commercial granites (modified after Streckeisen, 1976).

\subsubsection{Mafic rocks}

The Uruguayan mafic rock rocks have $\mathrm{SiO}_{2}$ values between 48.6 (Mahoma Gabbro, Bossi and Schipilov, 2007) and 49.27 wt\% (Arapey Black Basalt), FeOt values between 8.82 and 13.96 wt\%, MgO between 3.04 and 4.74 wt\% and $\mathrm{CaO}$ between 6.97 to 8.67 wt\%. These rocks belong in the basic to intermediate field (Table 3.2). The mafic rocks in this category all have a tholeitic affinity and their intrusion occurred in an extensional regime (Bossi and Campal, 1991; Bossi and Schipilov, 2007).

The rocks belonging to the mafic rock group are characterized by their black color resulting from their mineralogical composition and grain size. The dolerites have been extensively studied by Bossi and Campal (1991) and Morales Demarco et al (2011), and are described in chapter 2.

Mahoma Black is classified as a gabbro-norite according to geochemical and petrographical analyses (Oyhantçabal et al, 1990b; Bossi and Schipilov, 2007). The 
| Case study: Granitoids and syenitoids

mineralogy is composed of plagioclase, orthopyroxene, clinopyroxene, olivine and spinel, and as accessories pyrrotine, pentlandite, chalcopyrite, pyrite, marcasite, valleriite, violarite, magnetite, ilmenite and magnetite (Oyhantçabal et al, 1990b; Bossi and Schipilov, 2007).

Table 3.2: Major element composition of the commercial granites (in wt\%).

\begin{tabular}{ccccccccccccccc}
\hline Sample & $\mathrm{SiO}_{2}$ & $\mathrm{TiO}_{2}$ & $\mathbf{A l}_{2} \mathbf{O}_{3}$ & $\mathbf{F e O}_{\mathbf{t}}$ & $\mathbf{M n O}$ & $\mathbf{M g O}$ & $\mathbf{C a O}$ & $\mathrm{Na}_{2} \mathbf{O}$ & $\mathbf{K}_{2} \mathbf{O}$ & $\mathbf{P}_{2} \mathbf{O}_{5}$ & $\mathbf{F e}_{2} \mathbf{O}_{3}$ & $\mathbf{H}_{2} \mathbf{O}$ & $\mathbf{C O}_{2}$ & $\mathbf{m g \#}$ \\
\hline U49 & 49.27 & 3.51 & 12.38 & 13.96 & 0.21 & 4.72 & 8.67 & 2.44 & 1.33 & 0.46 & 15.51 & 1.14 & 0.08 & 0.25 \\
U2 & 75.34 & 0.24 & 12.48 & 1.58 & 0.04 & 0.27 & 0.93 & 2.77 & 5.22 & 0.07 & 1.76 & 0.56 & 0.11 & 0.15 \\
U4 & 67.75 & 0.46 & 16.45 & 2.66 & 0.05 & 0.99 & 3.45 & 4.74 & 1.83 & 0.14 & 2.95 & 0.78 & 0.17 & 0.27 \\
U53 & 66.67 & 0.52 & 16.34 & 3.11 & 0.06 & 1.21 & 3.73 & 4.60 & 1.84 & 0.17 & 3.46 & 0.92 & 0.17 & 0.28 \\
U70 & 70.71 & 0.34 & 14.23 & 1.97 & 0.05 & 0.73 & 2.22 & 2.69 & 4.53 & 0.10 & 2.19 & 1.24 & 0.79 & 0.27 \\
U71 & 71.59 & 0.34 & 13.94 & 2.02 & 0.05 & 0.60 & 1.87 & 2.65 & 4.76 & 0.13 & 2.24 & 1.18 & 0.49 & 0.23 \\
U73 & 72.8 & 0.25 & 13.70 & 2.21 & 0.03 & 0.38 & 1.66 & 3.58 & 3.87 & 0.07 & 2.45 & 0.73 & 0.19 & 0.15 \\
U83 & 71.9 & 0.23 & 15.00 & 1.85 & 0.03 & 0.41 & 2.51 & 4.48 & 1.98 & 0.07 & 2.06 & 0.66 & 0.34 & 0.18 \\
U93 & 73.00 & 0.28 & 13.70 & 2.03 & 0.06 & 0.36 & 1.16 & 2.94 & 4.84 & 0.18 & 2.26 & 0.79 & 0.20 & 0.15 \\
U94 & 67.8 & 0.42 & 16.00 & 2.97 & 0.05 & 1.15 & 4.35 & 4.41 & 1.22 & 0.12 & 3.30 & 0.70 & 0.18 & 0.28 \\
U95 & 71.9 & 0.26 & 14.50 & 1.69 & 0.04 & 0.53 & 2.24 & 2.91 & 4.29 & 0.08 & 1.88 & 0.87 & 0.31 & 0.24 \\
U7 & 72.3 & 0.36 & 12.22 & 3.49 & 0.05 & 0.11 & 1.59 & 2.34 & 5.54 & 0.07 & 3.88 & 0.67 & 0.37 & 0.03 \\
U74 & 73.7 & 0.23 & 13.30 & 1.80 & 0.03 & 0.17 & 1.33 & 3.48 & 4.72 & 0.05 & 2.00 & 0.45 & 0.23 & 0.09 \\
U76 & 71.3 & 0.27 & 14.40 & 1.31 & 0.02 & 0.47 & 1.15 & 3.71 & 5.69 & 0.10 & 1.45 & 0.47 & 0.34 & 0.26 \\
U88 & 70.2 & 0.36 & 14.10 & 1.85 & 0.01 & 0.64 & 1.56 & 3.86 & 4.87 & 0.14 & 2.05 & 0.68 & 1.15 & 0.26 \\
U15 & 69.2 & 0.26 & 15.49 & 2.09 & 0.06 & 0.21 & 1.09 & 4.55 & 5.65 & 0.06 & 2.32 & 0.64 & 0.11 & 0.09 \\
U46 & 61.48 & 0.61 & 17.72 & 4.17 & 0.14 & 0.48 & 2.36 & 5.82 & 5.17 & 0.14 & 4.63 & 0.59 & 0.20 & 0.10 \\
U47 & 65.06 & 0.33 & 16.41 & 4.19 & 0.16 & 0.04 & 1.44 & 5.34 & 6.26 & 0.03 & 4.66 & 0.71 & 0.13 & 0.01 \\
U92 & 66.6 & 0.29 & 15.10 & 3.94 & 0.13 & 0.01 & 0.62 & 6.11 & 5.44 & 0.02 & 4.38 & 0.47 & 0.24 & 0.00 \\
\hline
\end{tabular}

Table 3.3: Trace element composition of the commercial granites (in ppm).

\begin{tabular}{lccccccccccc}
\hline Sample & $\mathbf{B a}$ & $\mathbf{C r}$ & $\mathbf{G a}$ & $\mathbf{N b}$ & $\mathbf{N i}$ & $\mathbf{R b}$ & $\mathbf{S r}$ & $\mathbf{V}$ & $\mathbf{Y}$ & $\mathbf{Z n}$ & $\mathbf{Z r}$ \\
\hline U49 & 384 & 45 & 22 & 23 & 39 & 15 & 439 & 481 & 35 & 143 & 238 \\
U2 & 225 & 22 & 19 & 14 & 12 & 300 & 50 & 14 & 60 & 41 & 168 \\
U4 & 680 & 27 & 22 & 8 & 11 & 42 & 620 & 29 & 12 & 56 & 224 \\
U53 & 854 & 32 & 21 & 9 & 11 & 37 & 703 & 36 & 14 & 66 & 189 \\
U70 & 569 & 25 & 17 & 9 & 12 & 164 & 152 & 29 & 22 & 23 & 143 \\
U71 & 590 & 21 & 19 & 6 & 14 & 184 & 137 & 31 & 23 & 36 & 160 \\
U73 & 1160 & 24 & 17 & 13 & 16 & 88 & 160 & 18 & 19 & 49 & 196 \\
U83 & 1119 & 16 & 18 & 12 & 14 & 57 & 645 & 9 & 9 & 47 & 161 \\
U93 & 293 & 13 & 23 & 21 & 12 & 336 & 72 & 12 & 34 & 48 & 164 \\
U94 & 536 & 24 & 20 & 11 & 23 & 34 & 487 & 42 & 13 & 53 & 128 \\
U95 & 608 & 18 & 17 & 18 & 19 & 170 & 183 & 20 & 26 & 30 & 114 \\
U7 & 1853 & 20 & 22 & 39 & 12 & 106 & 161 & $<9$ & 91 & 137 & 672 \\
U74 & 449 & 15 & 23 & 18 & 10 & 212 & 129 & 9 & 33 & 40 & 187 \\
U76 & 2238 & 18 & 22 & 12 & 19 & 151 & 1002 & 20 & 10 & 35 & 190 \\
U88 & 1426 & 29 & 25 & 11 & 21 & 176 & 588 & 26 & 9 & 9 & 191 \\
U15 & 725 & 23 & 23 & 42 & 10 & 152 & 174 & 13 & 39 & 62 & 407 \\
U46 & 2288 & 14 & 23 & 48 & 9 & 53 & 523 & 9 & 39 & 112 & 878 \\
U47 & 164 & 19 & 24 & 42 & 9 & 80 & 33 & $<9$ & 34 & 74 & 557 \\
U92 & 50 & 9 & 36 & 71 & 20 & 122 & 15 & 9 & 69 & 144 & 1068 \\
\hline
\end{tabular}



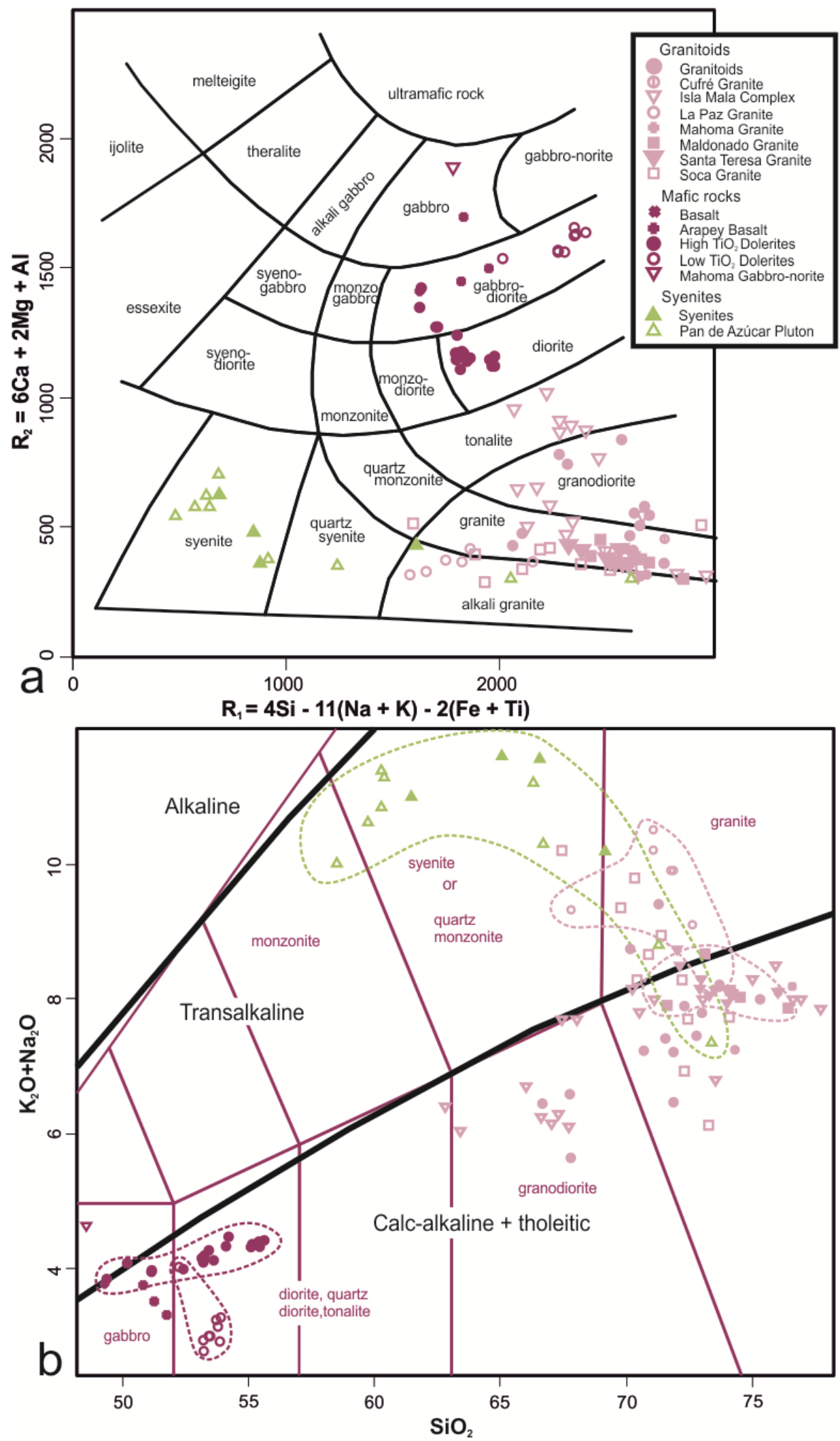

Fig 3.9: a. Distribution of commercial granites in Uruguay: a. R1-R2 diagram (after De La Roche et al, 1980), and b. TAS diagram (modified after Middlemost, 1997 and Best, 2003). Data of La Paz Granite after Oyhantçabal et al, 1990; 2010; Isla Mala Complex after Preciozzi, 1993; Soca Granite after Oyhantçabal et al, 1998; Santa Teresa Granite after Muzio and Artur, 1999; Pan de Azúcar Pluton and Maldonado Granite after Oyhantçabal et al, 2007b; Mahoma Gabbro-norite and Arapey Basalt after Bossi and Schipilov, 2007; Dolerites after Morales Demarco et al, 2011; Cufré and Mahoma Granite after Oyhantçabal et al, 2010; basalt, granitoids and syenites this study. 
Arapey Basalt belongs to the Arapey Group, which is composed of several lava flows that show variations in the geochemical and mineralogical composition. In general, the rocks are medium-grained and composed of plagioclase and pyroxene with a subophitic texture (Fig. 3.10c). Some of the lava flows also contain olivine, granophyric intergrowths and opaques (Bossi and Schipilov, 2007). The analyzed rock belongs to the Itapebí Formation (Bossi and Schipilov, 2007). Its mineralogy comprises plagioclase, augite, opaques (magnetite and hematite), limonite and a minor amount of quartz. The augite is partially transformed to limonite, however finely disseminated limonite is also homogeneously distributed throughout the rock (Table 3.4). This leads to the assumption that the rock is already partially weathered.

\subsubsection{Granitoids}

The granitoid rocks have $\mathrm{SiO}_{2}$ values that range from 66.67 to 75.34 wt\%, classifying them in the field of acid rocks. $\mathrm{FeO}_{\mathrm{t}}$ varies from 1.31 to $3.49 \mathrm{wt} \%, \mathrm{MgO}$ from 0.11 to 1.21 and $\mathrm{CaO}$ from 0.93 to $4.35 \mathrm{wt} \%$. The total alkalis range from 5.63 to $9.4 \mathrm{wt} \%$, thus these rocks can be classified as transalkaline to calc-alkaline or tholeitic (Table 3.2 and Fig. 3.9). They can be classified by their color in gray, red and greenish-gray and by their grain size in fine-, medium, coarse- and very coarse-grained.

The mineralogy of the granitoids is represented by alkali feldspar (microcline and orthoclase), sometimes containing perthites (Moskart Granite), plagioclase, quartz, biotite, muscovite and hornblende (Table 3.4 and Fig. 3.10). Accessories are magnetite, pyrite, hematite, epidote, apatite, titanite, garnet, stilpnomelane, chlorite and calcite. Isla Mala is the only granitoid that contains ilmenite. Pyrite is always found as traces. Chamangá Granite is classified as a granodiorite and Isla Mala as a tonalite; the other granitoids that compose this group are classified as granites s.s. (Fig. 3.8).

Some of these granites show signs of deformation. Cufré Granite shows a complete recrystallization of quartz, evidenced by the very fine-grained texture of this mineral and the absence of undulose extinction (Fig. 3.10f). The alkali feldspar (microcline) shows incipient recrystallization at the borders of the crystals, but also in thin cracks filled by very fine-grained feldspar crystals along larger crystals. A gentle foliation is 
| Case study: Granitoids and syenitoids

observable in the quarry and in extracted blocks, which is determined by the lineation of biotite crystals and mafic microenclaves. The Maldonado Granite has undergone a more intense synmagmatic deformation related to the activity of the SBSZ as described by Oyhantçabal (2005). This granite has a very well-developed foliation, with alternating bands some more rich in biotite and others rich in feldspar and quartz (Fig. 3.10h).

Table 3.4: Modal composition of the commercial granites studied. Abbreviations after Kretz (1983) except the ones marked with *: Ab: albite; Amph*: amphibole; Aug: augite; Bt: biotite; Cal: calcite; Chl: chlorite; Festil*: ferristilpnomelane; Gr. Int.*: graphic intergrowth; Hbl: hornblende; Lm: limonite; Mc: microcline; Ms: muscovite; Op*: opaques; Or: orthoclase; Pl: plagioclase; Qtz: quartz).

\begin{tabular}{|c|c|c|}
\hline ID & Commercial Name & Modal analysis (vol.-\%) \\
\hline U49 & Arapey & 3Qtz, 40PI, 31Aug, 17Lm, 90p \\
\hline $\mathrm{U} 2$ & Maldonado & $51 \mathrm{Qtz}, 34 \mathrm{Mc}, 10 \mathrm{PI}, 5 \mathrm{Bt}$ \\
\hline U4 & Chamangá & 31Qtz, 90r, 7Mc, 38PI, 15Bt \\
\hline U53 & Cuchilla del Perdido & 33Qtz, 260r, 29PI, 10Bt, 1Aug, 1Hbl \\
\hline U70 & Cerro Áspero & 30Qtz, 360r, 6Mc, 8PI, 12Bt, 7Ms, 1Cal \\
\hline U73 & Cufré & $40 Q \mathrm{tz}, 10 \mathrm{r}, 29 \mathrm{Mc}, 24 \mathrm{PI}, 6 \mathrm{Bt}$ \\
\hline U83 & Goñi & 45Qtz, 280r, 24PI, 3Bt \\
\hline U92 & Pan de Azúcar & 8Qtz, 800r, $11 \mathrm{Hbl}$ \\
\hline U93 & Santa Teresa & 18Qtz, 63Mc, 10PI, 9Bt \\
\hline U94 & Isla Mala & $42 \mathrm{Qtz}, 1 \mathrm{Mc}, 53 \mathrm{PI}, 4 \mathrm{Bt}$ \\
\hline U95 & Garzón Granite & 46Qtz, 32Or, 6Mc, 13PI, 3Bt \\
\hline U7 & Moskart & 41Qtz, 46Mc, 8PI, 1Hbl, 2Festil, 2Op \\
\hline U74 & La Paz & 25Qtz, 60Mc, 7PI, 7Bt, 1Hbl \\
\hline U76 & Guazunambí & 27Qtz, 15Or, 16Mc, 36PI, 4Bt, 1Aug, 1Cal \\
\hline U88 & Mahoma Red & 41Qtz, 70rt, 63Mc, 30PI, 6Bt \\
\hline U15 & Salmon Red & 12Qtz, 710r, 13PI, 2Hbl, 1Chl, 1Festil \\
\hline U46 & Artigas Pearl & $860 \mathrm{O}, 5 \mathrm{Pl}, 4 \mathrm{Hbl}, 5$ Festil \\
\hline U47 & Violeta Imperial & 11Qtz, 670r, 7PI, 8Hbl, 1Lm, 1Aug, 20p, 3Festil \\
\hline
\end{tabular}

The Guazunambí Granite shows deformation features suggesting that it also intruded during the activity of the SBSZ (Bossi and Navarro, 2001). In this granite the feldspars are all aligned and define a gentle foliation. 


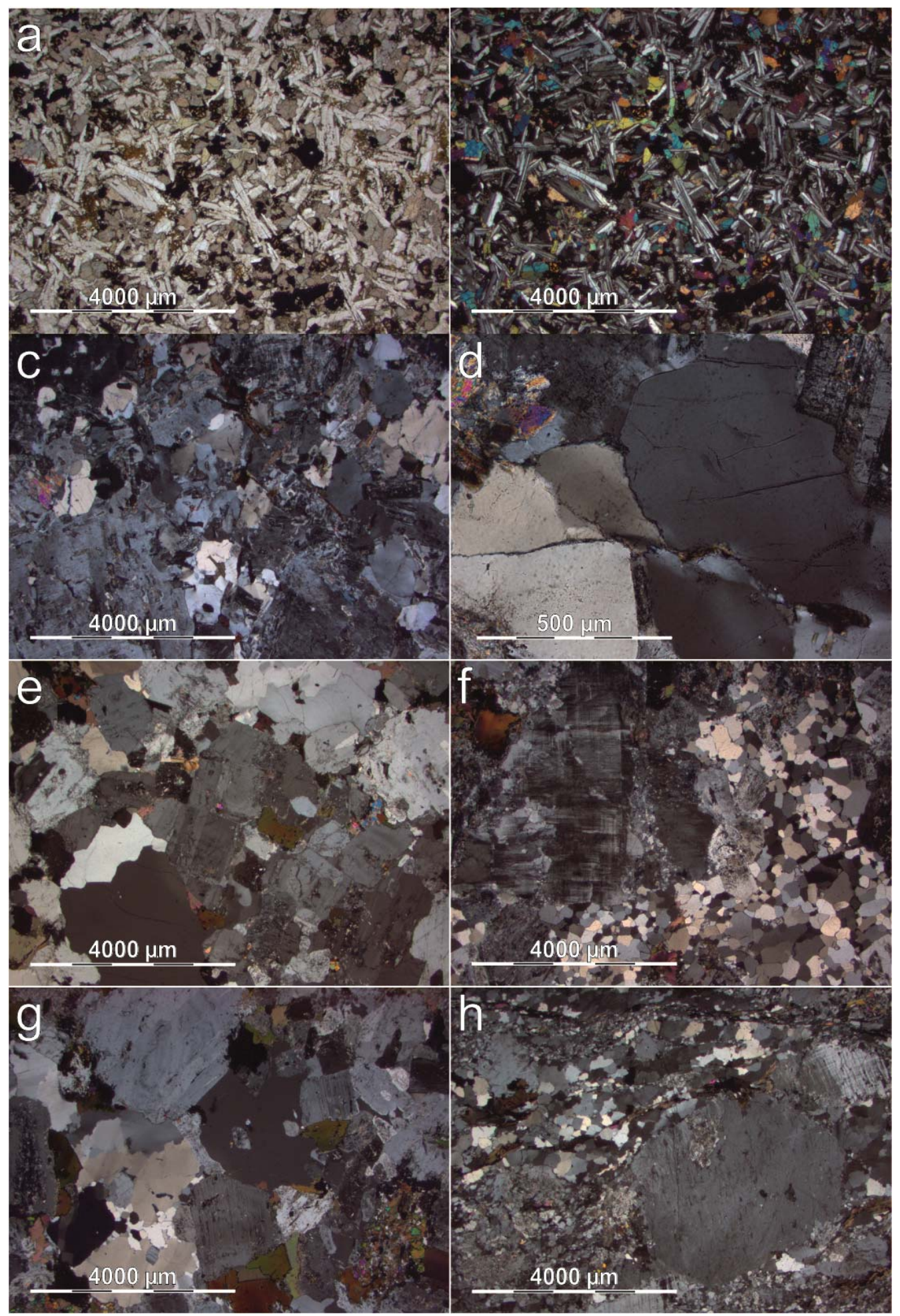

Fig. 3.10: Thin section images of black and gray commercial granites: a. Arapey Basalt (U49) with medium-grained subophitic texture in plane polarized light (PPL); b. Arapey Basalt (U49) in cross polarized light (CPL), note the subophitic texture between PI and Aug; c. Cerro Áspero Granite (U70) in CPL, fine- to medium-grained texture with Or and Qtz; $\mathbf{d}$. Cerro Áspero Granite (U70), note the microcracks in Qtz crystals; e. Chamangá Granite (U4) in CPL medium-grained texture with Qtz, PI, Or and Bt; f. Cufré Granite (U73) in CPL, to the right recrystallized Qtz (fine-grained) and to the left a Mc phenocryst; g. Cuchilla del Perdido Granite in CPL, medium-grained texture, Qtz, PI, Or and Bt;

h. Maldonado Granite in CPL, phenocrysts of Or and Mc in recrystallized matrix of Qtz with Bt. Abbreviations after Kretz (1983) except the ones marked with *: Aug: augite; Bt: biotite; Lm: limonite; Mc: microcline; Or: orthoclase; PI: plagioclase; Qtz: quartz. 


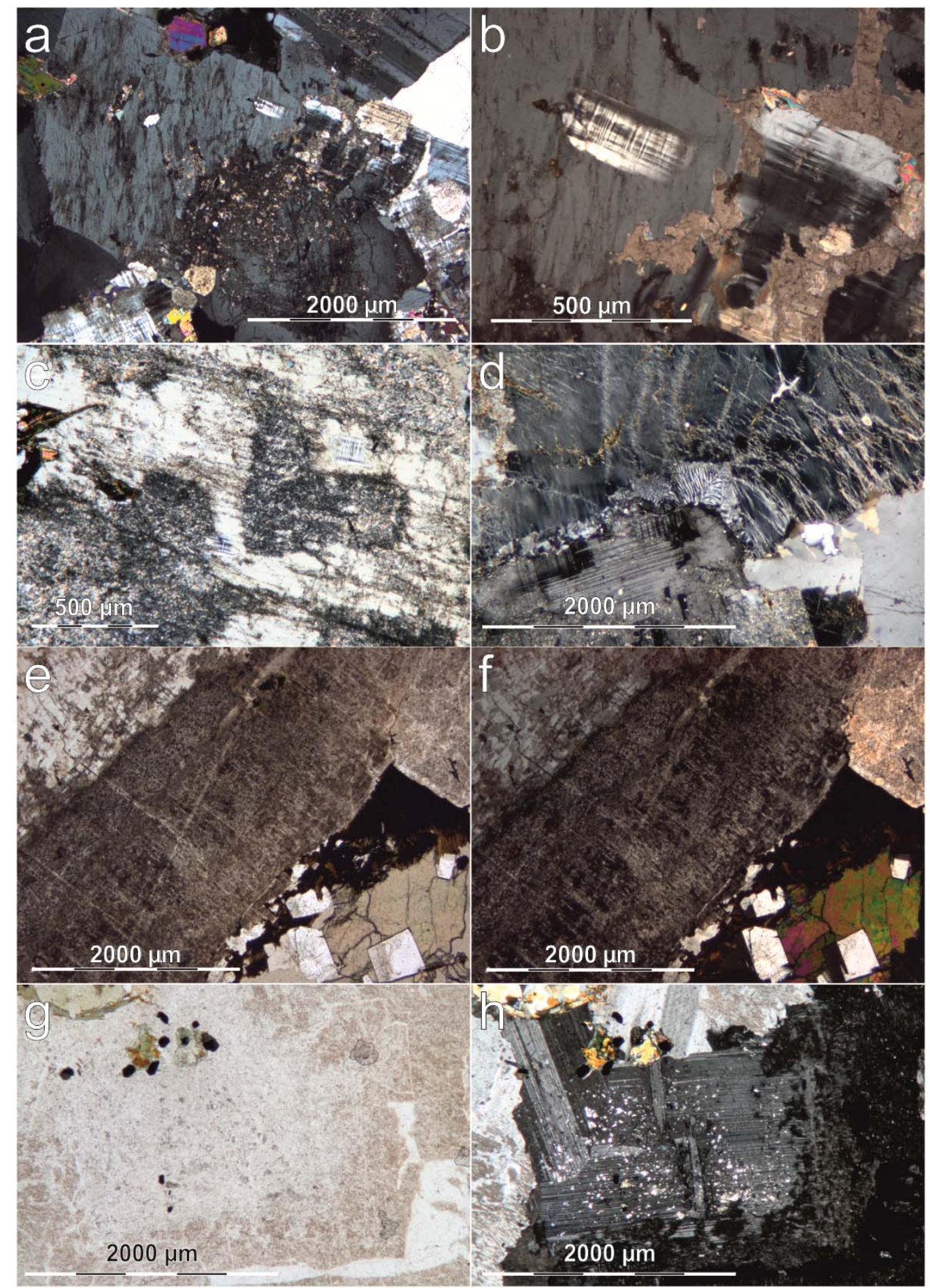

Fig. 3.11: Thin section images of colored commercial granites. a. Mahoma Red Granite (U88) in cross polarized light $(\mathrm{CPL})$, Or has partially substituted $\mathrm{PI}$, as evidenced by sericitization in the center of the image; b. Close-up of the previous image. Mc relicts appear partially surrounded by Cal in new formed

Or; c. Gray variety of Moskart Granite in CPL, PI with intense sericitization and relicts of Mc;

d. Moskart Granite (U7) in CPL, Qtz, Mc and PI compose the rock, intra and intercrystalline microcracks are filled by Chl, Bt, Ser, Cal and Lm; e. Artigas Pearl Syenite (U46) in plane polarized light (PPL), observe the reddening of Or crystals in contact with ferromagnesian agglomerations; f. same as e but in CPL; g. Salmon Red Syenite (U15) in PPL, PI with sericitization and partially altered to Or, in top of image Bt partially altered to $\mathrm{Chl}$, and numerous Op grains; $\mathbf{h}$. same as g. but in CPL. Abbreviations after Kretz (1983) except the ones marked with *: Ab: albite; Amph*: amphibole;

Aug: augite; Bt: biotite; Cal: calcite; Chl: chlorite; Festil*: ferristilpnomelane; Gr. Int.*: graphic intergrowth; Hbl: hornblende; Lm: limonite; Mc: microcline; Ms: muscovite; Op*: opaques; Or: orthoclase; PI: plagioclase; Qtz: quartz; *Ser: sericite). 


\subsubsection{Syenitoids}

The geochemistry of the four syenitoid deposits studied is very similar, with values of $\mathrm{SiO}_{2}$ ranging from 61.5 to $69.2 \mathrm{wt} \%$ (i.e. intermediate to acid rocks, Table 3.2). The values of $\mathrm{Al}_{2} \mathrm{O}_{3}, \mathrm{TiO}_{2}, \mathrm{MgO}, \mathrm{CaO}$ and $\mathrm{Pe}_{2} \mathrm{O}_{5}$ are always higher in the Artigas Pearl. In the Pan de Azúcar White, the $\mathrm{Na}_{2} \mathrm{O}$ content is higher than in any other syenitoid or rock from the other groups considered.

The syenitoids are characterized by low amounts of quartz and plagioclase and high alkali feldspar contents (Table 3.4). Their grain size is coarse to very coarse, normally showing an inequigranular texture. The syenitoids are composed mainly of orthoclase, microcline and amphiboles, the latter are normally hornblende, but in the Pan de Azúcar White, sodic amphibole (probably riebeckite or arfvedsonite) is the main amphibole found. Other minerals that occur in these rocks appear as accessories: plagioclase, quartz, biotite, chlorite, pyroxene (normally aegirine-augite), ferristilpnomelane, calcite, epidote, tourmaline, magnetite and zircon. Artigas Pearl shows traces of pyrite. Based on their mineralogical composition, these rocks can be classified as alkali feldspar syenite, quartz alkali feldspar syenite and quartz syenites (Fig. 3.8).

\subsection{Technical aspects}

\subsubsection{Color and décor}

The mafic rocks mined in Uruguay as dimensional stones posses black and dark gray colors. These colors are determined by a relatively high proportion of mafic minerals (e.g. pyroxenes, amphiboles, opaque minerals) and by the occurrence of clear plagioclase.

The dolerite varieties Absolute Black and Moderate Black have been already described in the chapter 2 and will not be analyzed again in this chapter. Mahoma Black is a dark gray fine- to medium-grained gabbro-norite (Oyhantçabal et al, 1990b). The presence of sulfides in this rock (Oyhantçabal et al, 1990b; Bossi and Schipilov, 2007) limits its use as a dimensional stone to indoor applications, where 
| Case study: Granitoids and syenitoids

weathering processes do not alter its color or change the petrophysical and petromechanical properties.

The granitoids can be further classified according to two specific fabric features: grain size (fine, medium- and coarse-grained) and the relationships between the mineral components (equigranular, porphyritic, etc.).The gray granitoids owe their color to the relatively high amount of limpid and gray feldspar, quartz, low amounts of mafic minerals and the absence of iron hydroxides (e.g. limonite). They can be subclassified into: i. fine-grained: Cerro Áspero (Fig. 3.10d) and Garzón; ii. mediumgrained: Chamangá (Fig. 3.10e), Cufré (Fig. 3.10f) and Cuchilla del Perdido (Fig. 3.10g); and iii. very coarse-grained: Maldonado (Fig. 3.10h) and Santa Teresa. Cufré Granite shows recrystallization of quartz grains and a gentle foliation. The coarsegrained granites also have a porphyritic texture with a preferred orientation of the phenocrysts (Muzio and Artur, 1999; Oyhantçabal, 2005).

The red granites show a color range between carmine red and carmine pink, with small variations within a same variety. The red color in granitoids has been related to the presence of ferric iron oxides in the alkali feldspars, especially hematite (Boone, 1969; Taylor, 1977; Nakano et al, 2002; Putnis et al, 2007; Plümper and Putnis, 2009). Plümper and Putnis (2009) studied the re-equilibration of feldspars in the presence of a fluid phase in gray and red stained granites from southeast Sweden. They determined a three stage feldspar replacement within these rocks: $i$. the first stage consists of a replacement of original microcline by oligoclase due to fluid circulation (in the late magmatic stage) with a concomitant porosity development within the oligoclase; ii. a second stage is characterized by the circulation of $\mathrm{Na}$ enriched hydrothermal fluid leading to a replacement of the oligoclase by albite and sericite formation within the albite pores; and iii. the third stage includes fracturing and infiltration of a K-rich fluid that causes the K-feldspathization of sericite and albite with hematite precipitation in the orthoclase pores that produces the red coloration.

In all the Uruguayan red granites evidence of these feldspar replacements can be observed. In the Mahoma Red Granite, for example, the plagioclase contains sericite and calcite inclusions, as well as microcline relicts. The plagioclase is partially 
replaced by perthitic orthoclase and both feldspars show a red stain, probably due to precipitation of hematite (Fig. 3.11). The red granites are either medium-grained, with equigranular texture: Mahoma Red Granite, equigranular facies of the La Paz Granite; or medium to coarse-grained, with porphyritic texture (porphyritic facies of the La Paz Granite, Preciozzi et al, 1985; Oyhantçabal et al, 1990a) and eventually show a slightly orientation of their phenocrysts (Guazunambí and Luján Granites).

The Moskart Granite is greenish-gray to brownish-gray and very coarse-grained (Fig. 3.11c and d), with small variations of color in the area of the deposit. Bossi et al (1965) attributed its color to the growth of biotite and chlorite in the cleavage planes of microcline. On the other hand, Oyhantçabal et al (1998) suggested that a secondary paragenesis (stilpnomelane, chlorite, calcite, and bluish green amphibole) related to the activity of the SYSZ generates the color. The rock actually shows evidence of similar feldspar replacement as described for the red granites. It can also be observed in the gray non-commercial variety and the greenish-gray variety (commercialized as Moskart Granite) (Fig 3.11c and d). The main difference between these two color varieties is not the proportion of the feldspar replacement. The greenish-gray color of the commercial variety (Moskart Granite) is related to the presence of microcracks filled by chlorite, sericite, calcite and limonite. The differences in the distribution and proportions of these minerals determine the color variations observed in the quarries and in the commercialized Moskart Granite varieties.

All these granites can show structural elements that disrupt their décor. The most frequent disruptions are due to mafic enclaves, biotite accumulations, mafic and aplitic dikes, schlieren, synmagmatic and convolute layering.

As already described and illustrated by previous authors (Comunità Economica Europea-Uruguay, no date; Bossi and Navarro, 2001; Oyhantçabal et al, 2007a) the colors of the syenitoids are dark salmon, pink salmon and terracotta with white spots (Salmon Red), pale red-violet (Violeta Imperial) and light gray with black spots (Pan de Azúcar White). Artigas Pearl shows a distinct décor and color (Fig. 3.12), where bluish-gray feldspar crystals (up to $35 \mathrm{~mm}$ ), sometimes showing iridescence, are 
surrounded by a pink to intense crimson rim in their contact with the agglomerations of mafic minerals (up to $1 \mathrm{~cm}$ ). This kind of color combination is relatively seldom in magmatic rocks. It optically attenuates and softens the intense coarse-grained texture, so that this rock will be preferably used for eye-catching applications such as countertops and façades.

In these rocks the same feldspar replacements are observable as in the red and greenish-gray granites (Fig. 3.11e-h). Other evidences of hydrothermal alteration are the presence of biotite partially altered to chlorite, epidote and calcite (e.g. in the Red Salmon Syenite).

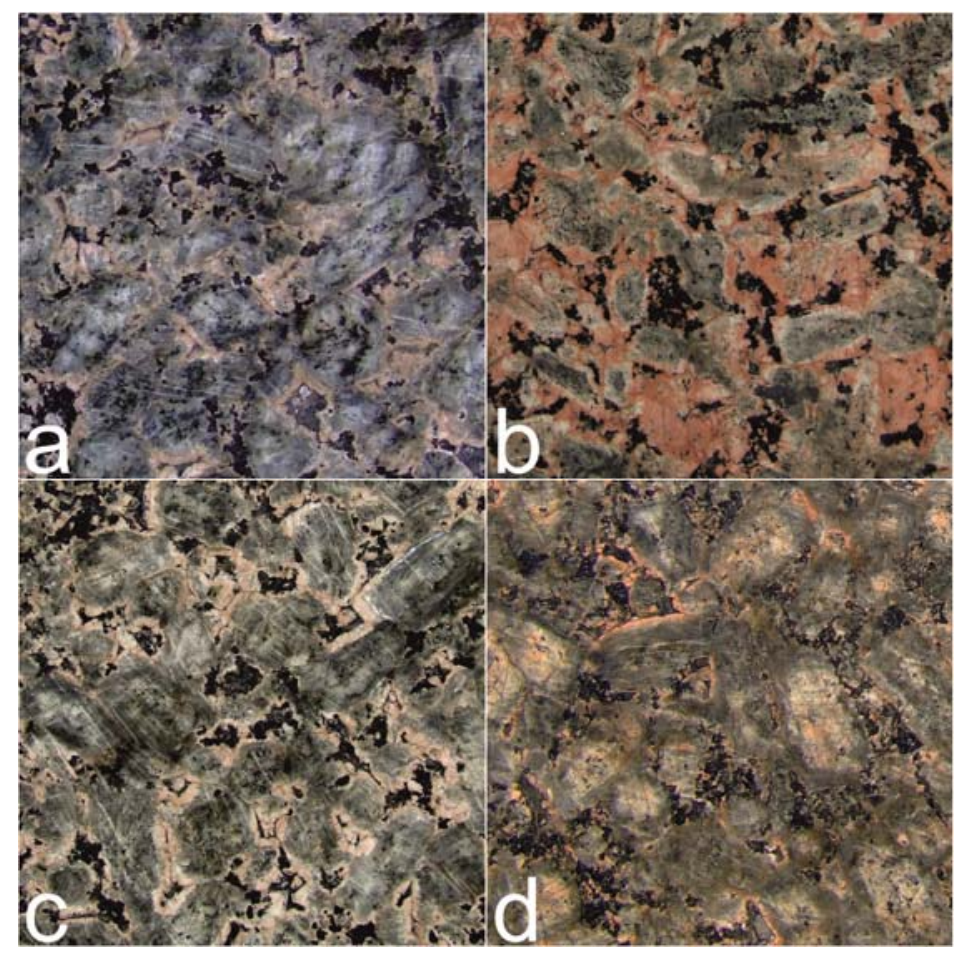

Fig. 3.12: Different colors and décors of Artigas Pearl Syenite (slab length $=10 \mathrm{~cm}$ ): $\mathbf{a}$. Typical color and décor; b. Intense red variety; c. Pale pink and gray variety; d. Same variety as in c. but with incipient weathering.

Salmon Red, Violeta Imperial and Pan de Azúcar White are coarse-grained, whereas Artigas Pearl is very coarse-grained and has a porphyritic texture (Fig. 3.11e and f). The texture is seriated in Salmon Red (Fig. 3.11g and h), Violeta Imperial and Pan de Azúcar White syenitoids, with feldspar crystals are between four to $15 \mathrm{~mm}$ in size. All the syenitoid deposits show occurrences of narrow schlieren (up to five millimeters), thin mafic dikes or aplitic veins, but only the Salmon Red and Violeta Imperial contain 
mafic enclaves. Due to the special décor of these rocks, small changes in mineralogy and alteration (hydrothermal and weathering) can lead to very visible changes in color and fabric. The case of the Artigas Pearl is a good example, since its décor varies from the more typical variety (Fig. 3.12a) to the very intense red or darker gray varieties (Fig. 3.12b and c), which modifies the market value of this rock.

\subsubsection{Petrophysical and petromechanical properties}

The potential uses of the dimensional stones can be deduced from their physical and mechanical properties, which in turn are closely related with their petrography and degree of weathering. As discussed in detail in numerous publications (see Siegesmund, 1994; Strohmeyer, 2003; Ruedrich, 2003; Koch, 2005; Hoffmann, 2006 and Mosch, 2008), the majority of the rocks when considering their fabric are anisotropic, and therefore, some of their physical properties are directionally dependent. To identify possible anisotropies these properties were measured in three orthogonal directions (Fig. 6.1, in general appendix). In the following subchapter just their mean values will be discussed. All the other data are listed in the appendix (Tables A.3.1, A.3.2, A.3.3 and A.3.4).

\subsubsection{Density and porosity}

The bulk density values of the Uruguayan commercial granites vary from $2.61 \mathrm{~g} / \mathrm{cm}^{3}$ for the Salmon Red Syenite and $2.94 \mathrm{~g} / \mathrm{cm}^{3}$ for the Arapey Black Basalt (Table A.3.1). All other Uruguayan commercial granites are in the above given range and in accordance with the values given in the compilation by Mosch and Siegesmund (2007) (Fig. 3.13a) and Siegesmund and Dürrast (2011). The mafic rock show the higher matrix density values determined by the higher proportion of heavier elements (mainly iron, calcium and titanium) forming minerals such as plagioclase, mafics and opaque minerals. The granitoids and syenitoids have lower amounts of these elements and higher proportions of the lighter elements (such as silicon and sodium), and therefore, show lower matrix densities. 
The water that a dimensional stone is capable to absorb and retain in the pore spaces, as well as its mobility within the pore network plays an important role in the weathering process and the petrophysical behavior (Peschel, 1977; Weiss, 1992, Siegesmund and Dürrast, 2011). Porosity, pore radii distribution, water uptake and capillary water uptake, and water vapor diffusion were determined in the samples studied in order to evaluate their durability when applied for constructive purposes (Table A.3.1).

In respect to their porosity all the mafic rock and syenitoid samples analyzed are outliers in the distribution of their respective groups as determined by the statistical compilation of Mosch and Siegesmund (2007) (Fig. 3.13b). The lower values, between 0.27 and $0.80 \%$, are registered by the granitoids (e.g. Chamangá Gray Granite). They have a very compact fabric, where the interstitial space is completely filled by anhedral quartz. The Arapey Basalt, with a subophitic texture shows a porosity of $0.98 \%$, the highest value in the mafic rock group. This fact is considered to be a consequence of the relatively altered or weathered condition of the Arapey Basalt samples studied as indicated by the presence of limonite and microcracks in plagioclase and pyroxene.

The syenitoids show the highest porosity values of the different commercial granites considered, where the highest porosity value was registered by the Violeta Imperial Syenite: $1.34 \%$. This rock, as in the other syenitoids studied, shows a more open interstitial space, where the feldspars show a complex replacement history (e.g. relict microcline in plagioclase showing albitization). The matrix is composed of a mixture of amphibole, pyroxene, chlorite, ferristilpnomelane and epidote, which indicates hydrothermal alteration and accounts for the higher porosity values measured.

The pore size distribution determined by mercury injection porosimetry shows a low variation between the different groups considered (Table A.3.1). Granitoids and syenitoids show a similar mean pore size, e.g. the fine-grained variety Cerro Áspero Gray has an average pore radius of $0.09 \mu \mathrm{m}$ and Artigas Pearl Syenite $0.08 \mu \mathrm{m}$. The most frequent pore radii are also very similar between all the rocks analyzed: between 0.008 (Artigas Pearl Syenite and Moskart Granite) and $0.335 \mu \mathrm{m}$ (Violeta 
Imperial Syenite). The pore size distribution has a significant influence on the water uptake and the capillary water uptake.

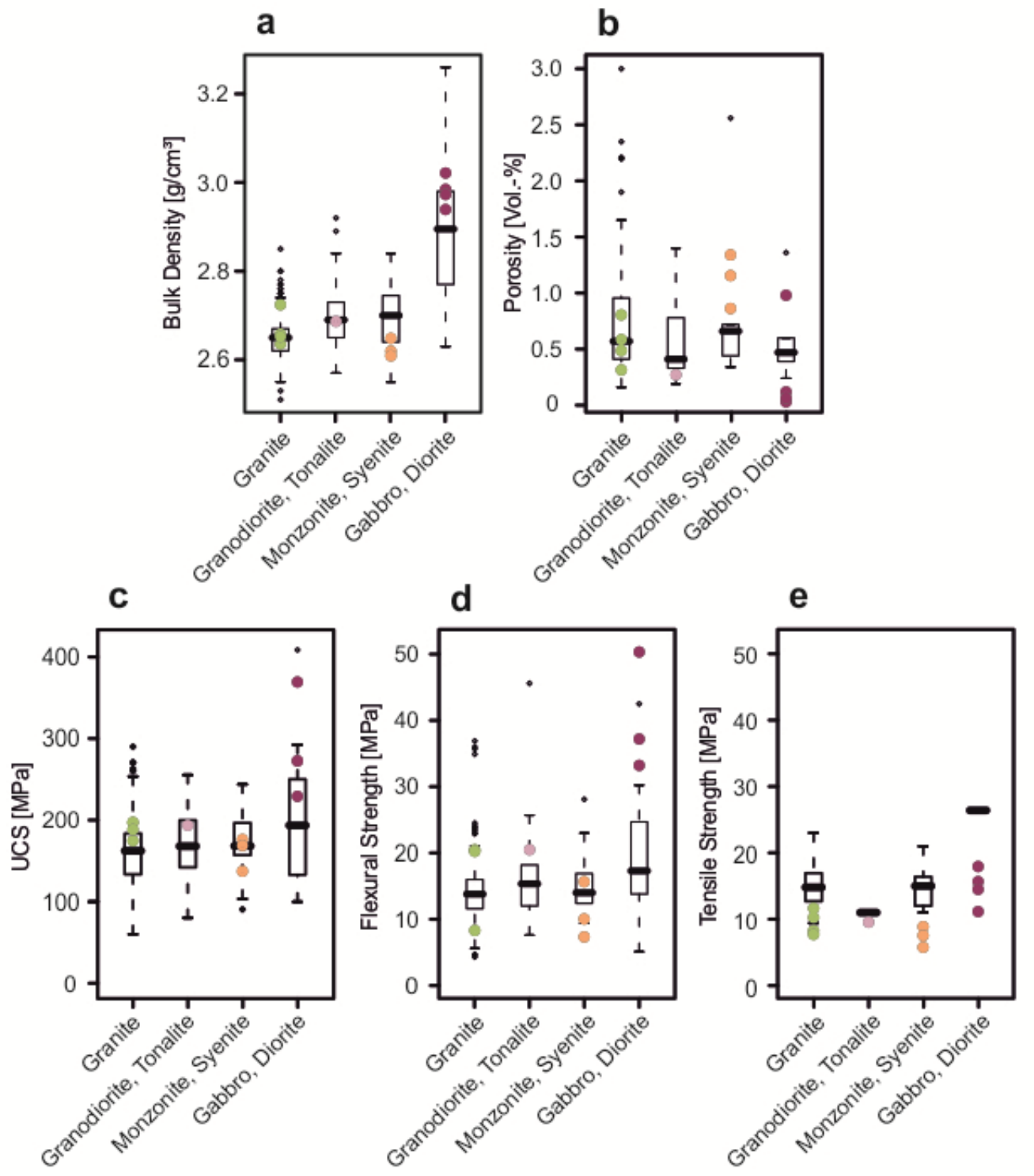

Fig. 3.13: Box plots of some petrophysical properties of commercial granites worldwide (redrawn after Mosch 2008) and Uruguay (each colored dot represents an average value): a. Bulk density;

b. Porosity; c. Uniaxial compressive strength (UCS); d. Flexural strength; e. Tensile strength.

The capillary water absorption is the main mechanism acting in pores with a radius between $0.1 \mu \mathrm{m}$ to almost $1 \mathrm{~mm}$ (Siegesmund and Dürrast, 2011). Since there is no water circulating in the pores the interactions between the rocks and the building materials (e.g. mortar) are insignificant, as well as the weathering processes that leads to the decay of the commercial granites. This is especially true for the granitoids, which show extremely low porosity and capillary water absorption. 
The water absorption (or water uptake) of the studied commercial granites is very low, in accordance with the very low porosity (Table A.3.1). The granites show low unforced water absorption values between 0.07 and $0.27 \mathrm{wt} \%$, whereas the basalt and the syenitoid have values between 0.28 and $0.43 \mathrm{wt} \%$ due to their higher porosity.

Water absorption values for granites are between 0.1 and $1.5 \mathrm{wt} \%$ (Peschel, 1977). The DIN 52008 defines that rocks with water absorption at atmospheric pressures (or unforced water absorption) less than $0.5 \mathrm{wt} \%$ are weathering resistant, as is the case for all Uruguayan commercial granites.

Fine-grained gray granites like the Cerro Áspero Gray (U70) are in demand because of their low water absorption (0.12-0.09, see Table A.3.1). The market for this kind of rock is led by the Chinese commercial granite Padang Light (G3533/G633). The data available for this granite are doubtful (Börner and Hill, 2010) and lower (0.36 wt\%, Table A.3.1) than in the unpublished reports from different Chinese providers, where the water absorption of Padang Light Granite ranges from 1.5 to $3.0 \mathrm{wt} \%$. The comparable granite from Uruguay, Cerro Áspero Granite, develops a lower amount of staining or spots due to its lower water absorption.

The saturation coefficient $S$ is the relation between the unforced water absorption and the forced water absorption, as defined by Hirschwald 1912. The author related this value with the capacity of a rock to resist weathering and freezing. All Uruguayan commercial granites show a very high S-value, but as described in Siegesmund and Dürrast (2011), this coefficient has little application in the case of plutonic and metamorphic rocks with a bulk density higher than $2.6 \mathrm{~g} / \mathrm{cm}^{3}$. This assumption is derived from the fact that the porosity of these rocks tends to be very low, and therefore, their capacity to interact with water. This lack of interaction between the rock and water leads to a better rock stability against weathering and freezing. 
| Case study: Granitoids and syenitoids

\subsubsection{Water vapor diffusion}

The highest vapor diffusion value indicates the higher resistance of the rock to the transmissivity of water, therefore the lowest permeability. Granitoids and syenitoids show similar values, with the exception of the Maldonado Granite, which has the lowest value of 83 (dimensionless) in the x-direction due to its fabric anisotropy (Table A.3.2). The other rocks in these groups show values between 374 (Moskart Granite) and 1,508 (Salmon Red Syenite). The values obtained in the present research for granitoids and syenitoids are in the range of those published by Siegesmund and Dürrast (2011) that measured values between 811 and 3,869 for plutonic rocks.

In applications where the water vapor diffusion can have an impact, such as façades and fountains, the anisotropy of this petrophysical property should be taken into account. One example is the Maldonado Granite, which has an anisotropy of 1:3:3 in the $x-, y-$, and $z$-direction. Therefore, considering the direction of the cut is necessary.

\subsubsection{Ultrasonic wave velocities}

In addition to the static Young's modulus, it has become commonplace to determine the dynamic Young's modulus by measuring the ultrasonic velocity for evaluating the degree of structural damage in dimensional stones (Köhler 1991, Siegesmund and Dürrast 2011). Under dry conditions the Vp (compressive waves) velocities should be above $5 \mathrm{~km} / \mathrm{s}$ in unweathered granitoids (Illiev 1967).

The Uruguayan commercial granites show ultrasound velocities ( $\mathrm{Vp}$ ) between 3.38 km/s (Cerro Áspero Granite in z-direction) and the $5.58 \mathrm{~km} / \mathrm{s}$ (Arapey Black Basalt in y-direction). The only samples showing anisotropy values higher than $10 \%$ are Maldonado Gray Granite, with around 10\% anisotropy and around $21 \%$ in the Cerro Áspero Gray Granite. 
| Case study: Granitoids and syenitoids

Sampling was carried out exclusively in fresh rocks, with the exception of the Arapey Basalt, where this was not possible. The values presented here can be used as standards for comparative measurements of fresh and unweathered rocks.

\subsubsection{Thermal expansion}

Numerous dimensional stones have a weathering sensitivity/vulnerability against thermal stresses, caused by an expansion of the material at high temperatures and a contraction with subsequent cooling. The thermal expansion is essentially controlled by the mineralogical composition and fabric of the rock (Koch and Siegesmund, 2004; Koch, 2005; Siegesmund et al, 2008).

In granites the thermal expansion and its associated processes (e.g. progressive microcracking leading to bowing) are more complex than in marbles. This is mainly due to the monomineralogical composition of marbles (calcite or dolomite), in contrast to granites that have at least three minerals present or generally more. Each mineral has a different thermal expansion and some of them are anisotropic with respect to this property. Quartz has the lowest thermal expansion coefficient ( $\alpha$ ) parallel to the c-axis $\left(7.7 \times 10^{-6} \mathrm{~K}^{-1}\right)$ and the highest perpendicular to it $\left(\alpha=13 \times 10^{-6}\right.$ $\mathrm{K}^{-1}$ ) (Siegesmund et al, 2008). Biotite is also anisotropic with $\left(\alpha=17.3 \times 10^{-6} \mathrm{~K}^{-1}\right)$ parallel to the c-axis and $9.7 \times 10^{-6} \mathrm{~K}^{-1}$ perpendicular to it (Siegesmund et al, 2008). High plagioclase contents lead to low a values, due to the extremely small volume expansion of this mineral (Weiss et al, 2004).

Castro de Lima and Paraguassú (2004) analyzed the thermal expansion coefficient (a) of 19 commercial granites and concluded that an increment in porosity leads to a decrease in $\alpha$, whereas an increment in grain size or quartz content increases $\alpha$. These authors also analyzed the directional dependency of $\alpha$, concluding that for the samples studied there is no dependency.

The thermal expansion coefficient $(\alpha)$ for the commercial granites varies from 5.74 (Artigas Pearl in the $\mathrm{x}$-direction) to $9.47 \times 10^{-6} \mathrm{~K}^{-1}$ (Moskart in the y-direction) (Table A.3.2). The range of values obtained is comparable with those reported for magmatic 
rocks by Strohmeyer (2003), Hoffmann (2006), Weiss et al (2004), Siegesmund et al, 2008 and Vázquez et al, 2011. The mafic rock show the lowest mean $\alpha$, since this rock show the lowest mean grain size and quartz content, and the highest proportion of plagioclase. Granitoids show the highest mean $\alpha$ value and the highest quartz content. The syenitoids, with intermediate a values, show a low proportion of quartz and the highest porosity values. These relationships are in accordance with the observations made by Castro de Lima and Paraguassú (2004) and Vázquez et al (2011).

Generally, the samples show anisotropies lower than $11 \%$ in their thermal expansion, but there are two cases where higher anisotropies were measured: Artigas Pearl Syenite (15\%) and Moskart Granite (18\%). Both commercial granites are very coarse-grained. A similar behavior was reported by Vázquez et al (2011) in three coarse- to very coarse-grained commercial granites.

Differential deterioration can occur in light-colored granitoids with dark-colored enclaves or xenoliths due to the albedo effect or differential thermal response to insolation (Gómez-Heras et al, 2008, Steiger et al, 2011). The deterioration will generally be expressed by the spalling of enclaves or xenoliths (Gómez-Heras et al, 2008).

The thermal expansion behavior of a dimensional stone is closely related to its bowing behavior when applied as slabs for outdoor façade cladding (Siegesmund et al, 2008; Vázquez et al, 2011). For bowing the same factors influencing thermal expansion are relevant: coarse- to very coarse-grained texture, mineral shapepreferred orientation and porosity (Vázquez et al, 2011).

When considering a building application with thermal exposure from one direction (e.g. façades), the rocks showing a high anisotropy in thermal expansion and flexural strength should be used in the most favorable direction (the one showing higher resistance to deterioration processes). The potential bowing behavior of a commercial granitic rock must be examined prior to its use as a building element. 


\subsubsection{Petromechanical properties}

\subsection{Uniaxial compressive strength (UCS)}

According to Mosch and Siegesmund (2007), uniaxial compressive strength (UCS) values in plutonic rocks vary from 60 to $292 \mathrm{MPa}$; the values for the gabbro-diorite subgroup are always in the upper quartile (Fig. 3.13c). In Uruguayan commercial granites the same behavior can be observed (Table A.3.3 and Fig. 3.13c). The Arapey Black Basalt shows a mean UCS value of $228 \mathrm{MPa}$. The granitoids belong to the granite and granodiorite-tonalite groups determined by Mosch (2008). They show higher UCS values than the median for both groups, for some granite this value is higher than the upper quartile (197 MPa for Cuchilla del Perdido and Cerro Áspero granites). The syenitoids (monzonite-syenite group of Mosch 2008) also show higher or similar values that the median for this group, with the exception of the Artigas Pearl Syenite that has an UCS value lower than the lower quartile (137 MPa).

The only rock analyzed showing a distinct rock fabric and a stretching lineation is the Maldonado Granite (Oyhantçabal, 2005). However, this rock also shows no anisotropy in the compressive strength.

\subsection{Young's modulus}

The maximum Young's modulus $\mathrm{E}$ value is $32.9 \mathrm{GPa}$ for the Chamangá Gray Granodiorite in the y-direction (Table A.3.3). The Cuchilla del Perdido Granite shows the lowest value: $11.9 \mathrm{GPa}$ in the z-direction. A general trend, similar to that described by Hoffmann (2007), can be observed in the relationship of the Young's Modulus $E$ and the UCS. The samples that have the higher UCS also have the higher Young's Modulus E.

\subsection{Indirect tensile strength}

The indirect tensile strength values for all commercial granites considered are lower than the lower quartile determined by Mosch (2008) and most of the values are 
outliers in the normal statistical distribution (Fig. 3.13e). The higher values are those of Cerro Áspero Gray Granite (11.7 MPa) and Arapey Black Basalt (11.1 MPa). Artigas Pearl Syenite shows the lowest value (5.8 MPa), followed by Moskart granite (7.7 MPa) (Table A.3.3).

\subsection{Flexural strength}

Comparing the flexural strength values with those of Mosch (2008) (Fig. 3.13d), it can be seen the granitoid groups show values that are either higher than the upper quartile (Cuchilla del Perdido and Maldonado granites, with 20.2 and $20.4 \mathrm{MPa}$, respectively) or lower than the lower quartile (Moskart Granite, with 8.3 MPa) (Table A.3.4). Chamangá Granodiorite shows a flexural strength that is higher than the upper quartile (20.4 MPa). The syenitoid group shows very different values. Salmon Red is in the upper quartile (15.6 MPa), the Violeta Imperial value is lower than the lower quartile (10.0 MPa) and Artigas Pearl is 8.3 MPa.

\subsection{Breaking load at dowel hole}

Values obtained for breaking load at the dowel hole vary between $1.8 \mathrm{kN}$ (Moskart Granite) and $3.2 \mathrm{kN}$ (Maldonado Gray and Cuchilla del Perdido granites) (Table A.3.4). Mafic rocks show the highest values, followed by the granitoids with the exception of Moskart Granite and then the syenitoids, with the lowest values, in particular Artigas Pearl Syenite with $1.9 \mathrm{kN}$. Due to its fabric anisotropy, the Maldonado Granite was tested in three different directions according to the standard procedure. It shows a variation between 2.8 (Type Ila, dowels parallel to foliation) and $3.5 \mathrm{kN}$ (Type Ilb, dowels perpendicular to foliation). According to the data of Rohowski (2001), mafic rocks can be compared with mafic volcanics and tephrite (basalt lava) with breaking load values around $4 \mathrm{kN}$. The granitoids and syenitoids can be compared with the granite and gneiss of Rohowski (2001), with values around $3 \mathrm{kN}$.

A slab with a thickness of $30 \mathrm{~mm}$ composed of coarse-grained or very coarse-grained granitoids or in particular syenitoids, can eventually be represented by only two or 
three crystal grains. This kind of slab can thus have a limited strength (flexural, indirect tensile and compressive strengths, and breaking load at the dowel hole) and durability.

\subsection{Abrasion strength}

The lower values of abrasion strength show the higher resistance of the rock to abrasion, therefore the rock most resistant to abrasion is the Maldonado Gray Granite with a value of $2.2 \mathrm{~cm}^{3} / 50 \mathrm{~cm}^{2}$ (Table A.3.4). The less resistant rock is Arapey Basalt, with a value of $3.8 \mathrm{~cm}^{3} / 50 \mathrm{~cm}^{2}$. All Uruguayan commercial granites have lower values than those discussed in the literature (Peschel 1977, Strohmeyer 2003, Siegesmund and Dürrast 2011).

The difference in the mechanical strength values observed between the various rocks considered can be explained by the fact that they differ in their mineralogical composition and fabric (Strohmeyer, 2003). The granitoids, with the exception of Moskart Granite, show the highest strength values and this is related to specific characteristics of their fabric that make them more resistant: a medium grain size, compact texture where quartz seals the interstitial spaces between the other mineral crystals making the rock very cohesive. This is well illustrated when comparing the UCS and flexural strength values with the bulk density and porosity (Fig. 3.14).

Generally, the very coarse-grained rocks show the lowest strength values; this is the case in the Moskart Granite and Artigas Pearl Syenite. This is probably related to the presence of microcracks and the cleavage of the large alkali feldspar present in these rocks. The strength of a rock can also be correlated with the bulk density and effective porosity: the higher density of a rock and the lower its porosity determines higher strength values (Morales Demarco et al, 2007; Mosch, 2008). This correlation can be observed in all commercial granites considered in the present study (Fig. $3.14)$. 

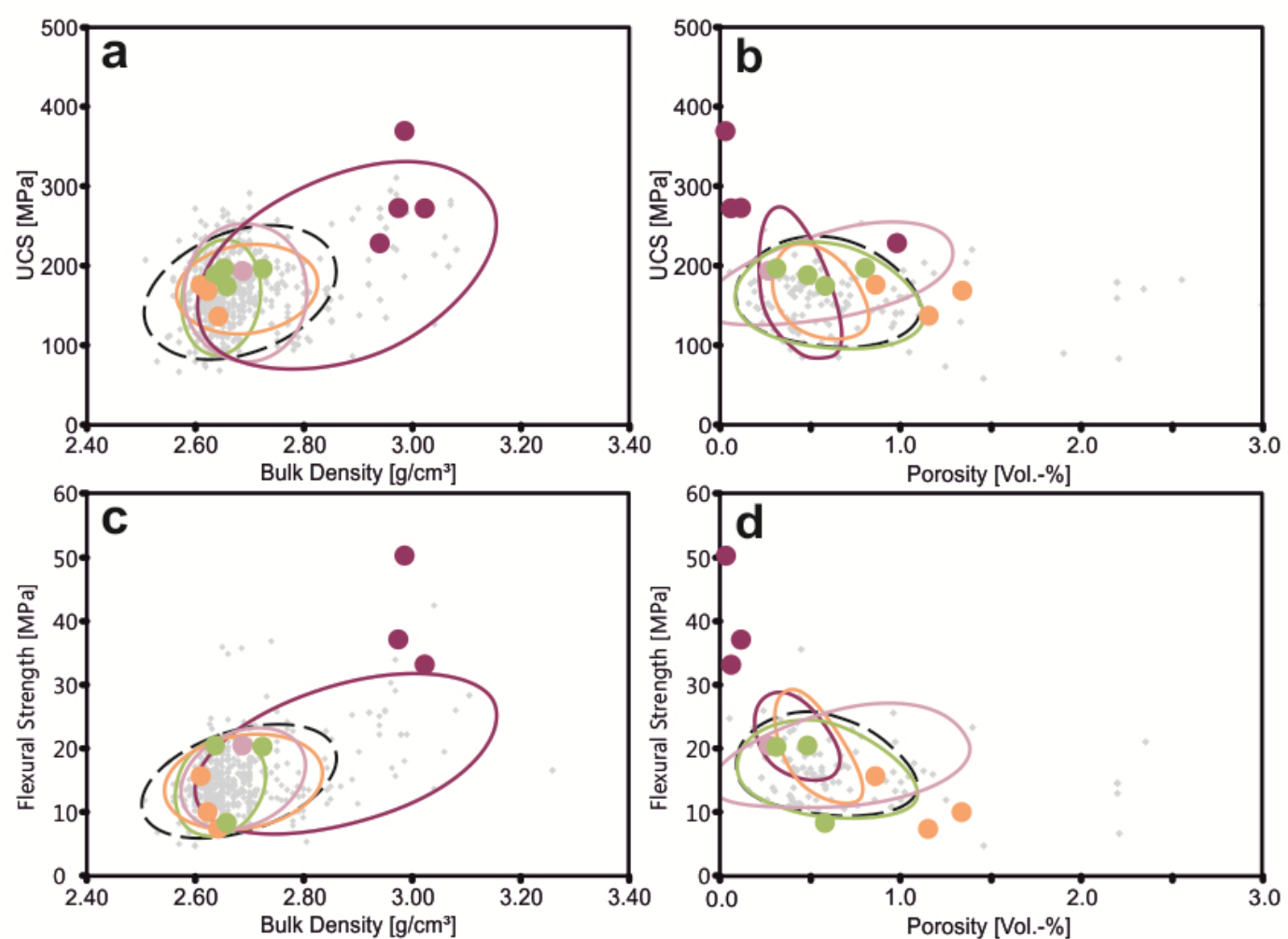

S Plutonite total 8 Gabbro, Diorite 8 Granite 8 Granodiorite, Tonalite

Fig. 3.14: Statistical values of some petrophysical properties of commercial granites worldwide (gray dots after Mosch 2008) and Uruguay (each colored dot represents an average value of a commercial granitic stone): a. Bulk density versus uniaxial compressive strength (UCS); $\mathbf{b}$. Porosity versus uniaxial

compressive strength, c. Bulk density versus flexural strength, d. Porosity versus flexural strength.

\subsection{Deposit characterization}

The evaluation of a mineral deposit is carried out following the International Framework Classification of the United Nations/UNFCR (UN 2009). The classification is based on three categories: i. degree of favorability of social and economic conditions (e.g. market prices, relevant legal and environmental conditions) (E axis); ii. maturity of studies and commitments to implement mining plans that determine the feasibility of the mining project ( $F$ axis); iii. level of confidence in the geological knowledge and potential recoverability of the quantities (the $G$ axis). Commercial projects are the ones feasible from a technical, economic and social point of view. Dimensional stone deposits are not representative of typical mineral deposits as for example massive mineral deposits (construction aggregates, e.g. sand, gravel). The industrial requirements in décor and block volume (or size, or dimensions) determine the selection of a section inside a deposit, in which these requirements are achieved and are at the same time demanded by the market (Stein, 2007). Basically, some 
aspects of the evaluation of aggregate deposits can be applied in the case of dimensional stones (Kelter et al, 1999). An example is the application of mining techniques (e.g. diamond wire saw) that have proved to be effective in comparable dimensional stone deposits.

The geological and mining knowledge of the analyzed deposits exhibits a highly differentiated state of the art. This ranges from a general assignment of a geotectonic unit (Cuchilla del Perdido Granite) to many years of geological investigations in active mining districts (dolerite deposits, e.g. Moderate Black Dolerite U8, U11O, U66). Both the growth of the international market for dimensional stone and the industrial development in the production requires more intensive research into the feasibility of mining the deposits:

1. The selection of the décor, especially the color is determined by international trends, which are not constant. Some trends are cyclical for decades, but others are acyclical. Rocks with colors outside of the prevailing trend are temporarily or only partially usable (e.g. the pink facies of Artigas Pearl Syenite).

2. The dimensional stone raw blocks are processed mainly in industrial plants. For this purpose the blocks must have, on one hand, an orthogonal form (Fig. 3.15) and a minimum size, and on the other hand the choice of the block size is often related to the optimal utilization of the resource related to the size of the end product (e.g. block size between 3.5 and $9 \mathrm{~m}^{3}$ ).

3. Due to modern requirements for the use and construction of buildings, rocks with the same color and décor will be chosen for a technical function in accordance to their maximum resistance of a selected property (e.g. rocks with high abrasion resistance as floor slabs). 

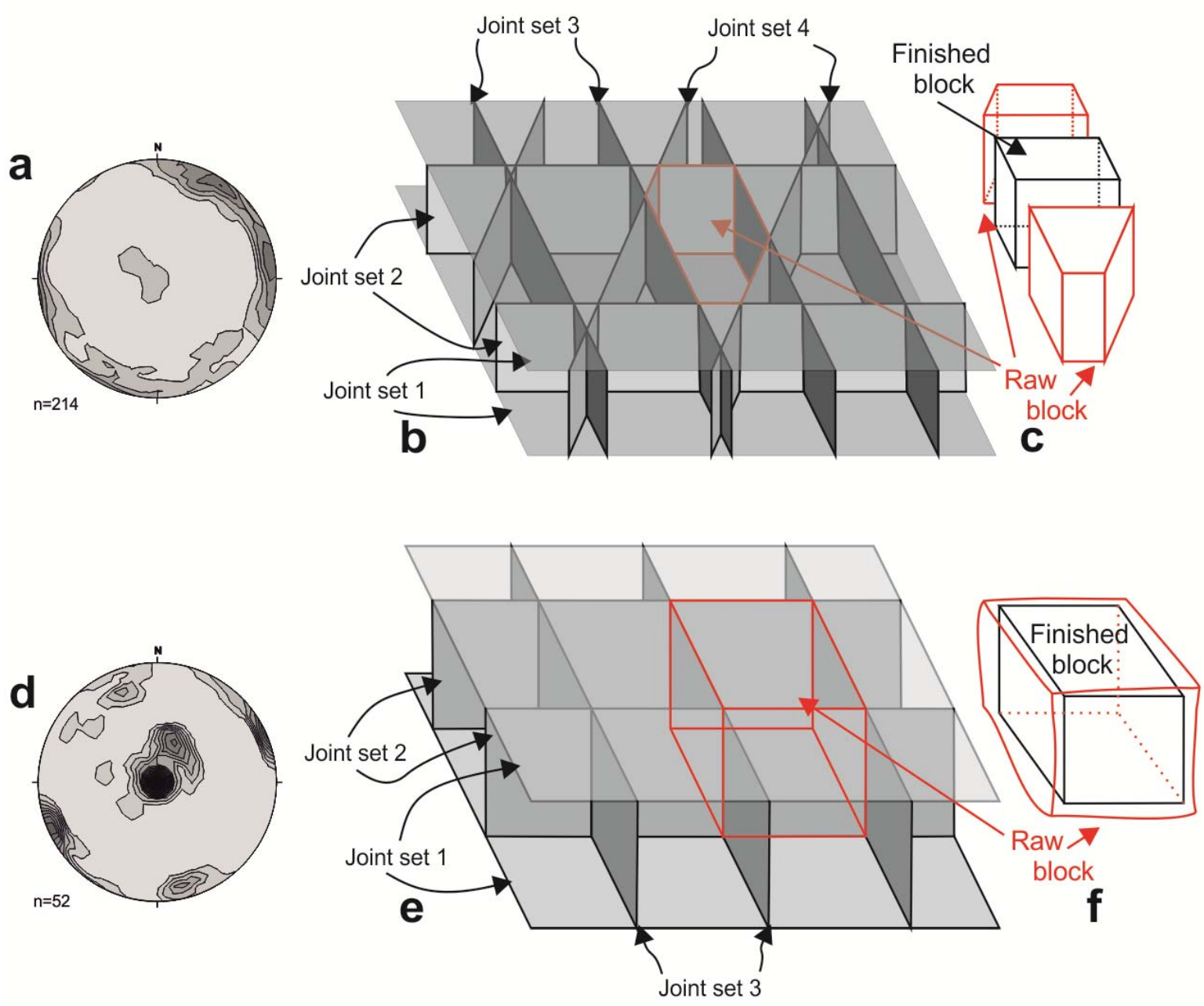

Fig. 3.15: a. Stereogram of the Salmon Red Syenite deposit; $\mathbf{b}$. Theoretical model of the joint sets affecting the Salmon Red deposit; c. Raw block resulting from the presence of the joint sets and possible block resulting from its squaring; $\mathbf{d}$. Stereogram of the Moskart Granite deposit; e. Theoretical model of the joint sets affecting the deposit; f. Raw block and finished block as a resulting of squaring.

The effects of the above mentioned international market mechanisms were directly decisive for the development of the natural stone industry in Uruguay in the last 20 years. Because of its natural conditions (climate), the country could not follow the international trend towards yellow dimensional stones in the years 1995-2006. This particular color is due to limonitic alteration of the rocks (a characteristic of tropical countries), which, nevertheless, retain their essential petrophysical properties. The rocks offered did not fulfill the international trend and their business volume significantly declined. Only the timeless décor and color offered by the dark gray to black dolerites occupy a permanent place on the international market. Even this segment needs qualitative development to be able to compete with the blocks offered from Northern China and India exhibiting larger dimensions. 
The criteria for deposit profitability require geologic studies that can determine the following controlling elements:

1. An inventory of the joint sets to determine the frequency of minimum dimension of exploitable blocks in order to achieve the optimal block size for the industry, as well as to minimize the waste material.

2. Mineralogical and structural factors that influence the formation, stability and variability of the fabric and color.

3. Factors of the genesis of the deposit, as well as the influence of alteration, which causes an impact on the relevant petrophysical properties, that favor or limit the usability.

\subsubsection{Block sizes}

For the evaluation of the yield of a quarry, the block sizes must be estimated. This can be done as described by Singewald (1992), Palmstrøm (1982, 1996 and 2001) and Sousa (2010). All these authors use the joint set frequency to estimate the mean or median block sizes. Singewald's (1992) method is the less complex to use, since it calculates $\mathrm{Vb}$ (block volume) by multiplying the average distribution of three main joint sets (see eq. 1). Palmstrøm (1982, 1996, 2001) uses the Jv (volumetric joint count) (see eq. 2) and $\beta$ (block shape factor; eq. 3) for calculating $\mathrm{Vb}$ (see eq. 4). Sousa (2010) uses Jmed (median volumetric joint count) (see eq. 5); the block volume was calculated afterwards using (eq. 4). The parameters $x, y, z$ and S1, S2, S3 are the distances between the different joints that compose a joint set, and $\alpha 1, \alpha 2$ and $\alpha 3$ the angles between these joint sets.

$\mathrm{V}_{\text {average }}=\mathrm{x}_{\text {average }}{ }^{*} \mathrm{y}_{\text {average }}{ }^{*} \mathrm{Z}_{\text {average }}$

$\mathrm{JV}=1 / \mathrm{S} 1+1 / \mathrm{S} 2+1 / \mathrm{S} 3$

$\beta=(\alpha 2+\alpha 2 * \alpha 3+\alpha 3)^{3} /\left(\alpha 2{ }^{*} \alpha 3\right)^{2}$

$V b=\beta$ *JV-3 * $1 / \operatorname{Sin} \alpha 1{ }^{*} \operatorname{Sin} \alpha 2{ }^{*} \operatorname{Sin} \alpha 3$ 


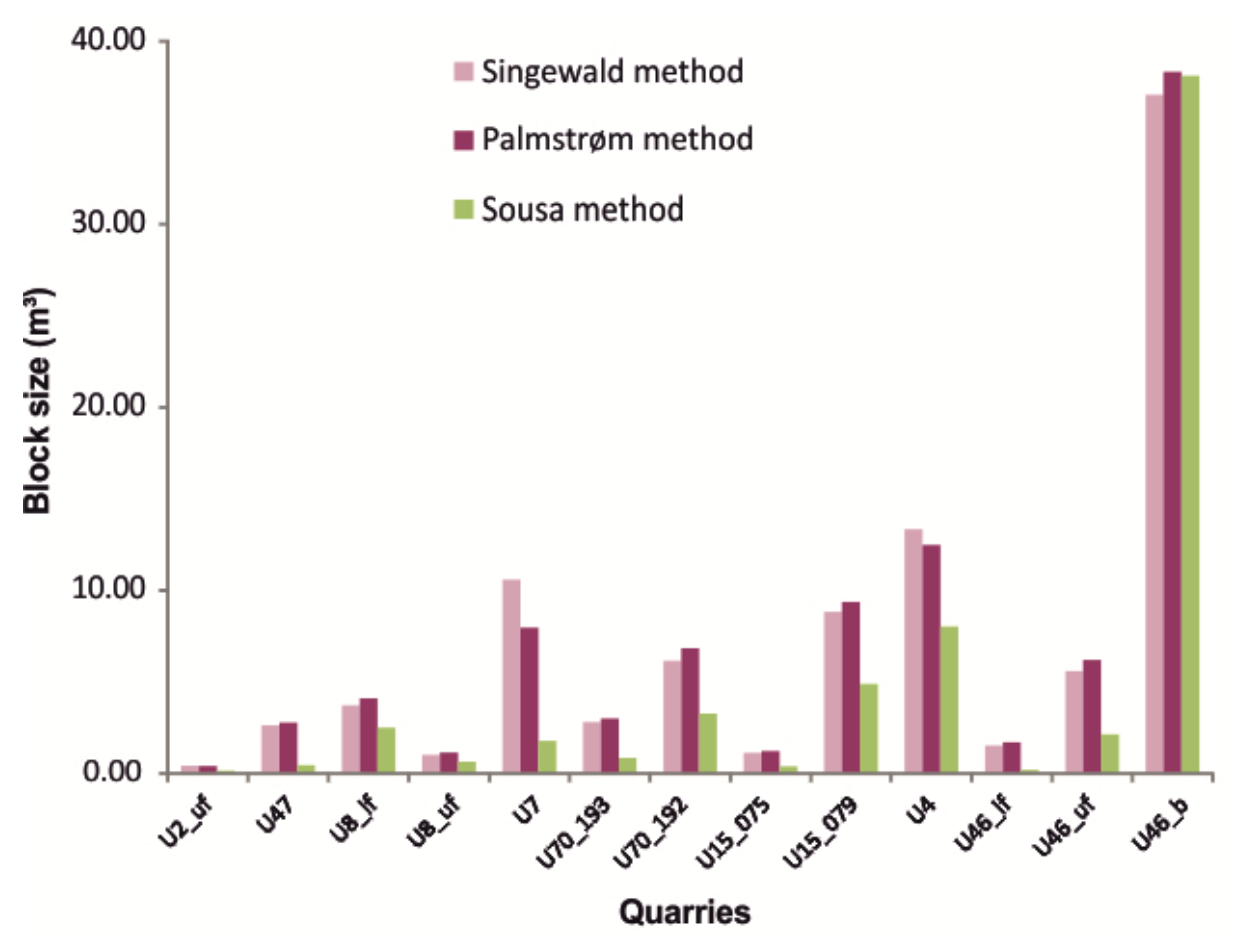

Fig. 3.16: Block sizes of the different quarries analyzed using three different methods: Singewald (1992), Palmstrøm $(1982,1996,2001)$ and Sousa (2010).

The three methods were applied in several Uruguayan quarries and different block sizes were obtained (Table 3.5 and Fig. 3.16). Table 3.5 shows that the Sousa method (2010) is the most conservative estimation, since it uses the median and not the average joint spacing as the other methods. For all the cases analyzed the joints were measured and afterwards their spacing, taking into account to which joint set they belong. The orientations of the joints are shown in the stereograms in Figure 3.17.

When possible, the joint sets as well as their spacing in more than one floor were measured. In the case of the Artigas Pearl syenite quarry, the boulder zone at the top of the deposit was also measured. The sizes of these boulders are greater than the average and median blocks calculated using the equations above for the floors in the quarry itself (Table 3.5). In the case of the Rosarito dolerite quarry, block sizes in the lower floor are higher than in the upper floor, since the joint density is also higher in the upper floor (Fig. 3.18). 
| Case study: Granitoids and syenitoids

Table 3.5: Block volume calculated using different methods. * Cufré Granite quarry data may not be representative of the whole deposit; ${ }^{* *}$ Chamangá Granite data Oyhantçabal (pers com 2011).

\begin{tabular}{ccccc}
\hline & \multicolumn{4}{c}{ Block size Vb $\left(\mathrm{m}^{3}\right)$} \\
Quarries & ID & $\begin{array}{c}\text { Singewald } \\
\text { method }\end{array}$ & $\begin{array}{c}\text { Palmström } \\
\text { method }\end{array}$ & $\begin{array}{c}\text { Sousa } \\
\text { method }\end{array}$ \\
\hline Sacramento Dolerite lower floor & U8_If & 3.73 & 4.12 & 2.51 \\
Sacramento Dolerite upper floor & U8_uf & 1.03 & 1.15 & 0.65 \\
Maldonado Granite lower floor & U2_If & 0.35 & 0.38 & 0.12 \\
Maldonado Granite upper floor & U2_uf & 0.43 & 0.41 & 0.17 \\
Chamangá Granite ** & U4 & 13 & 12 & 8 \\
Cerro Áspero Granite (quarry 193) & U70_193 & 2.81 & 3.01 & 0.86 \\
Cerro Áspero Granite (quarry 192) & U70_192 & 6.16 & 6.84 & 3.27 \\
Cufré Granite* & U73 & 689 & 756 & 163 \\
Moskart Granite & U7 & 10.6 & 8.0 & 1.8 \\
Salmon Red Syenite (quarry 075) & U15_075 & 1.14 & 1.23 & 0.40 \\
Salmon Red Syenite (quarry 079) & U15_079 & 8.83 & 9.38 & 4.89 \\
Artigas Syenite lower floor & U46_If & 1.53 & 1.71 & 0.20 \\
Artigas Syenite upper floor & U46_uf & 5.60 & 6.21 & 2.14 \\
Artigas Syenite boulder zone & U46_b & 37.1 & 38.3 & 38.1 \\
Violeta Imperial Syenite & U47 & 2.64 & 2.78 & 0.47 \\
\hline
\end{tabular}
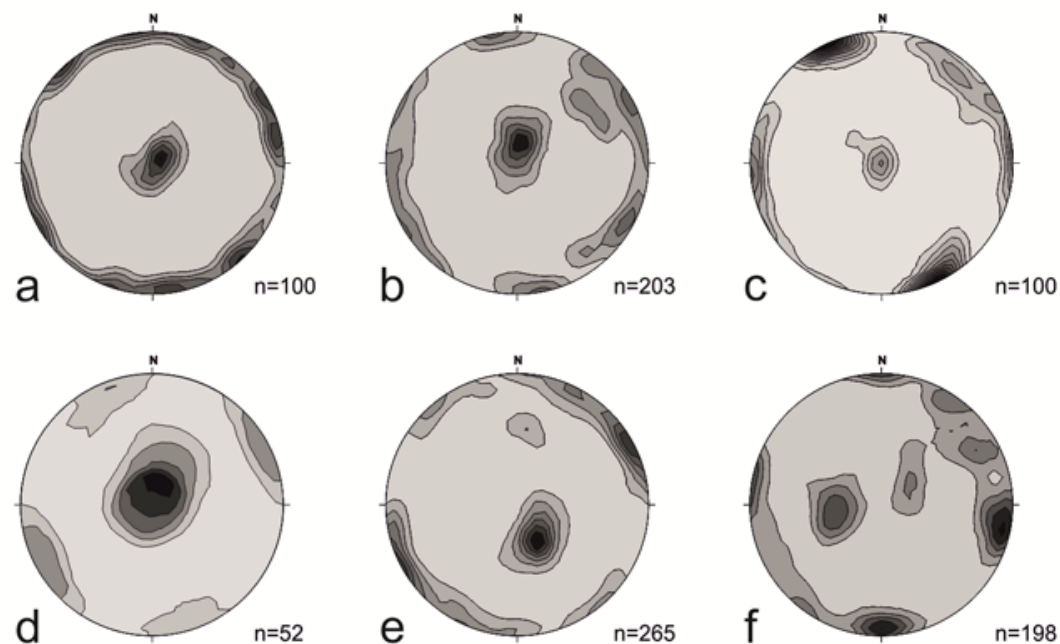

Fig. 3.17: Stereograms (equal area projection, lower hemisphere) showing the measured joints using Stereo Net: a. Arapey Basalt from the Cerro del Estado quarry (contours 1, 2, 3, 4, 5 times uniform distribution: t.u.d.); b. Cerro Áspero Granite quarries (contours 1, 2, 3, 4, 5, 6 times uniform distribution); c. Sacramento Dolerite from the Rosarito quarry (contours 1, 2, 3, 4, 5, 6, 7, 8, 9, 10 t.u.d.); d. Moskart Granite (contours 1, 2, 3, 4, 5 t.u.d.); e. Artigas Syenite (contours 1, 2, 3, 4, 5, 6, 7 t.u.d.); f. Violeta Imperial (contours 1, 2, 3, 4, 5 t.u.d.).

In the Maldonado Granite and especially in the Artigas Syenite the opposite occurs. A possible explanation for this abnormal behavior can be found in the two-stage landform development model proposed by Büdel (1957) and described by Twidale (2002). In the first stage, surface rock is affected by the weathering of the materials around the joints, and boulders start to form. Weathering then proceeds downwards 
into the subsurface, where the meteoric water stays longer in contact with the rock. In the second stage, the regolith between the joints of the surface is transported, but not with the regolith of the subsurface. Weathering can proceed more intensely in the subsurface since water is available.

This results in a boulder zone at the top and a weathered zone underneath, whose thickness depends on the intensity and duration of weathering. For dimensional granitic deposits it is important to determine the depth at which this weathering effect ends.

Another method for estimating block sizes can be done by using the software 3DBlock Expert described in Nikolayew et al (2007), Siegesmund et al (2007a, b) and Mosch et al (2010). This program provides a better spatial distribution of the blocks in the section of the quarry considered for an optimized extraction. Sections of three quarries were modeled using this program: the Maldonado Granite (Fig. 3.19), Cufré Granite and the Salmon Red Syenite (Fig. 3.20). In the Cufré Granite the whole quarry was modeled (a total volume of $9,979 \mathrm{~m}^{3}$ ), but the total amount of joints measured was very low (seven). The quarry is most likely not very representative of the global behavior of the deposit, and therefore, the results of the tectonic analyses overestimates the block sizes obtained by real mining.

In the Maldonado Granite model (Fig. 3.19a, b and c) two subvertical joint sets are observable, which are orthogonal to each other, and a third joint set that is subhorizontal with a significant dip (Fig. 3.19d and e). This last joint set affects the deposit negatively, since it diagonally crosscuts the blocks that would otherwise be regular. The joint set parallel to the yz-wall is determined by the foliation of the rock, as depicted in Figure 3.19a. The raw block size distribution (Fig. 3.19f) shows that the highest proportion of raw blocks is larger than $8 \mathrm{~m}^{3}$. 


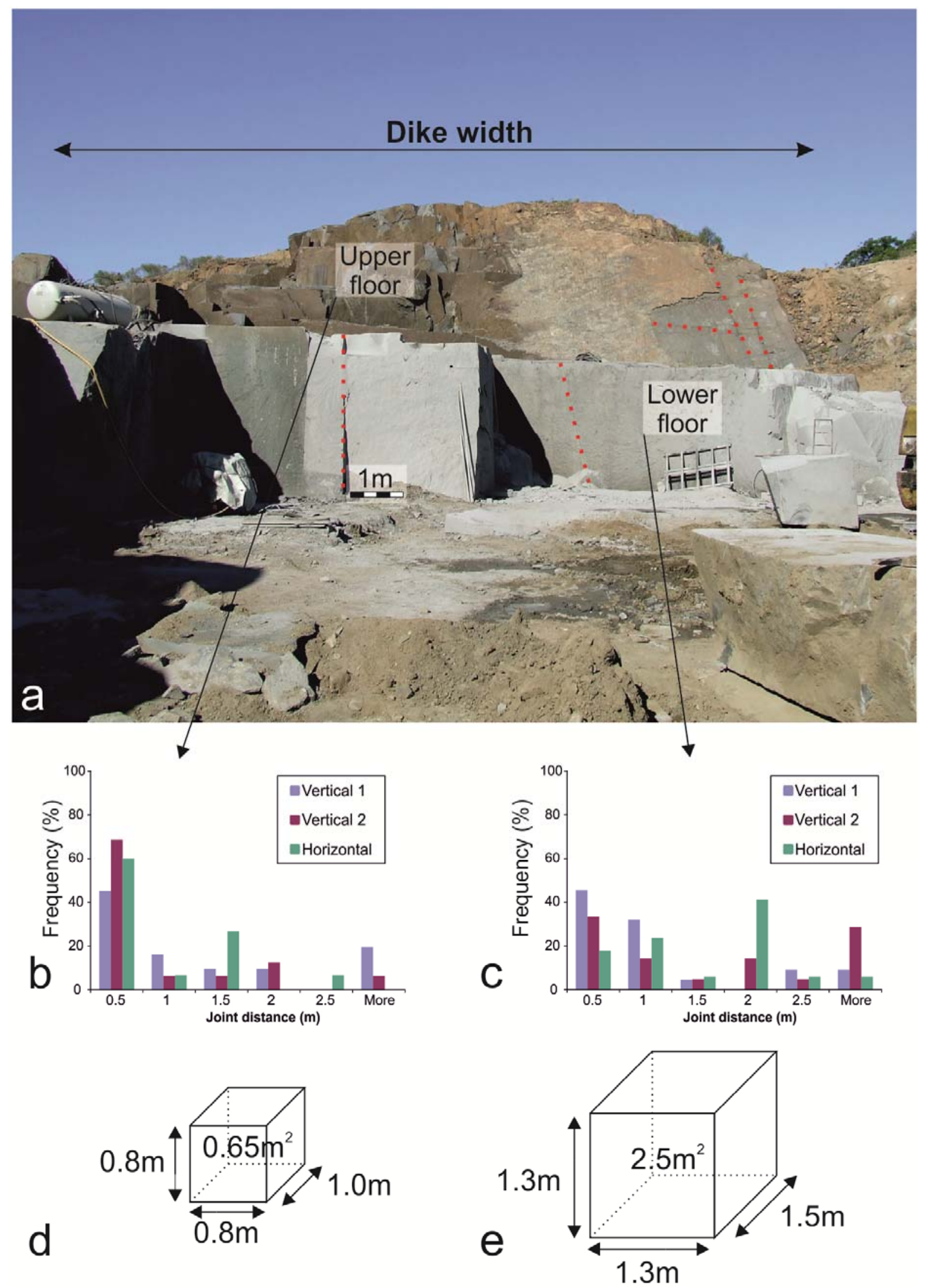

Fig. 3.18: Rosarito dolerite quarry: a. General view of the upper and lower floor; b. Joint set frequency of the upper floor; c. Joint set frequency of the lower floor; $\mathbf{d}$. Median block volume of the upper floor; e. Median block volume of the lower floor. 


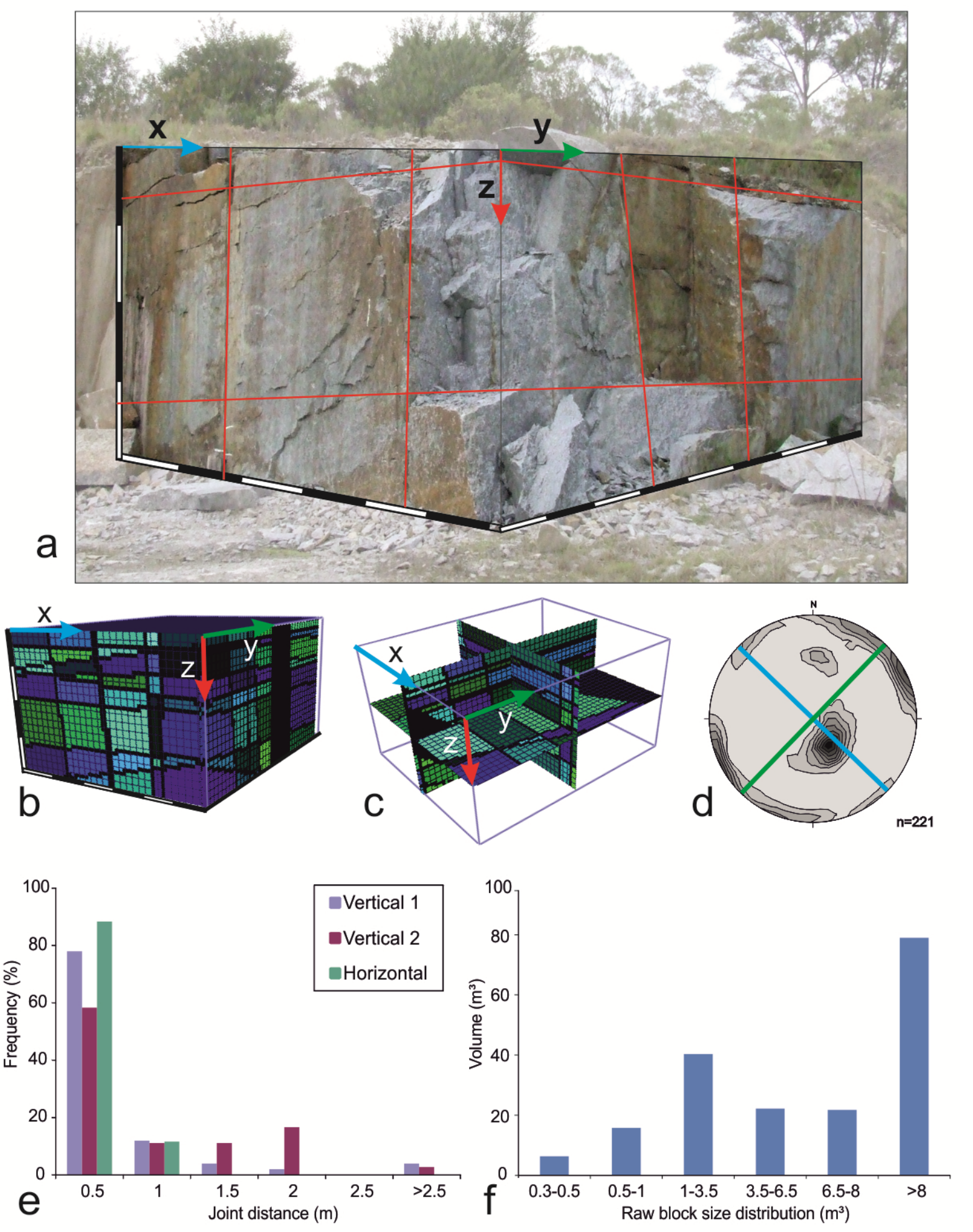

Fig. 3.19: 3D Model of the Maldonado Granite made using 3D Block Expert: a. Section of the quarry modeled (total volume $191 \mathrm{~m}^{3}$ ), some joints are marked in red, yz-plane is the foliation plane, scale in meters; b. and c. 3D view of the section modeled; d. Stereogram of the Maldonado quarry with walls of section modeled in blue $(x)$ and green $(y)$; e. Joint frequency histogram of the quarry; $\mathbf{f}$. Raw block volume distribution using 3D Block Expert. 


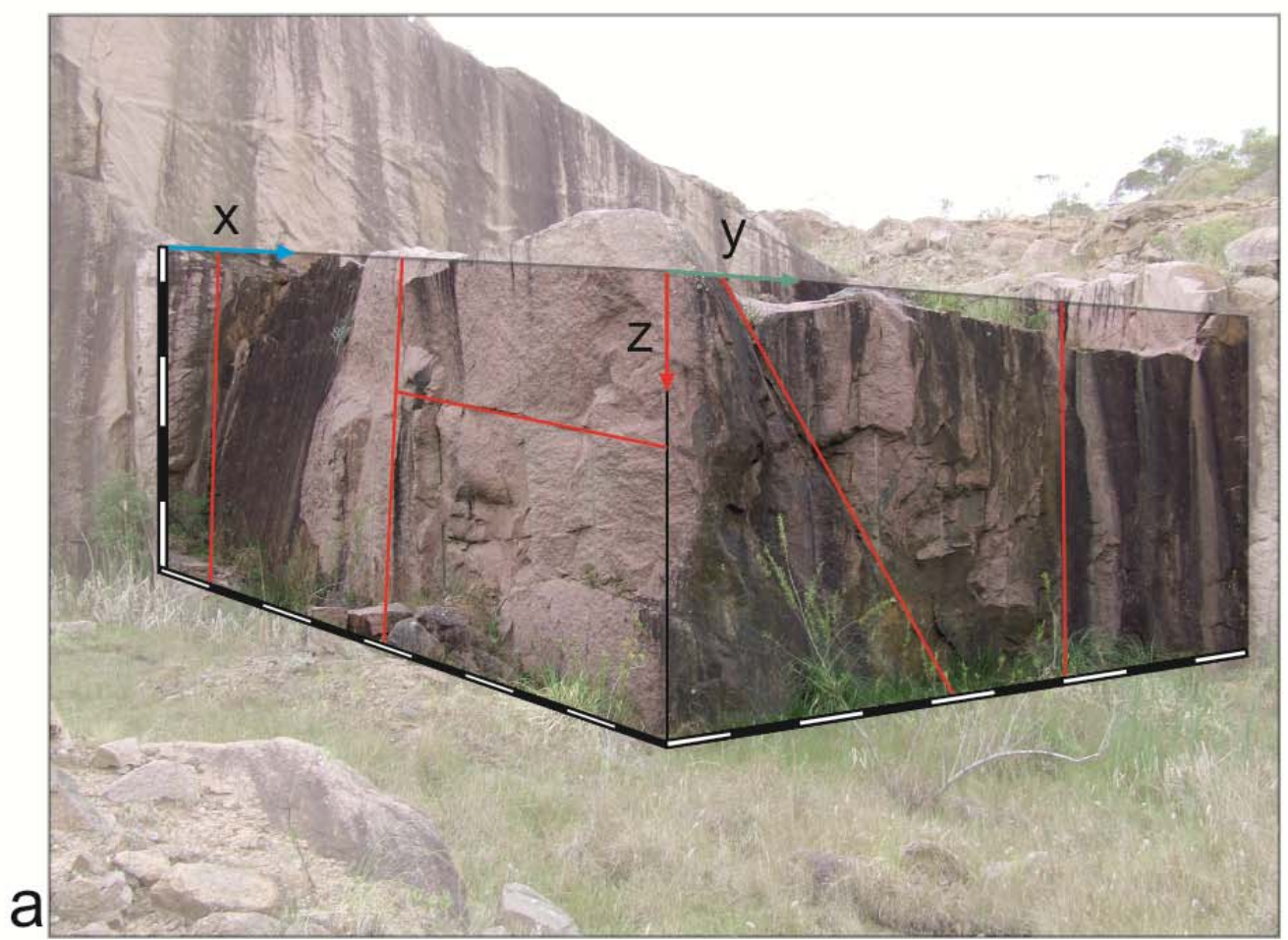

b
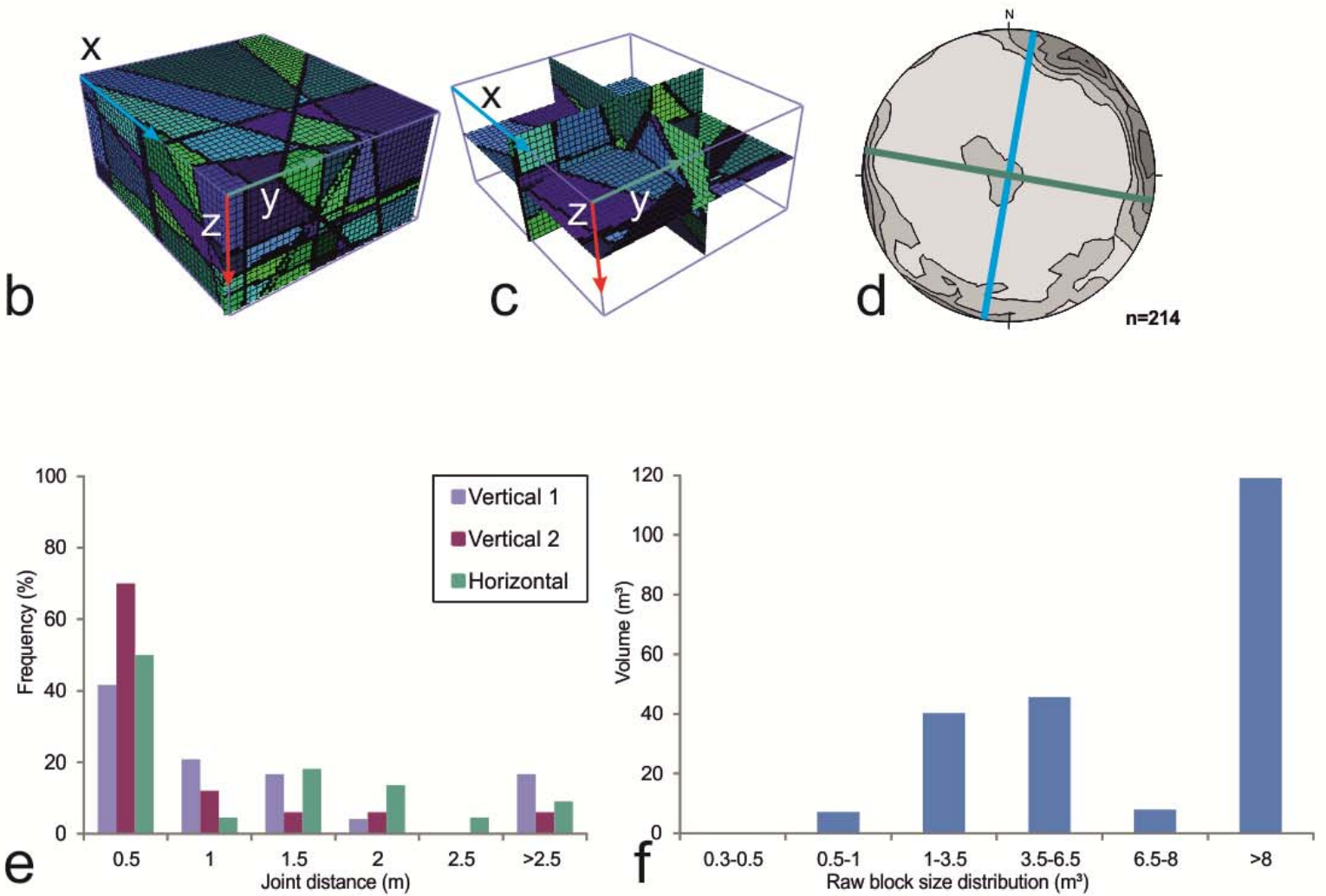

Fig. 3.20: 3D Model of the Salmon Red Syenite made using 3D Block Expert: a. Section of the quarry modeled (total volume $396 \mathrm{~m}^{3}$ ) with some of the joints marked in red, scale in meters; $\mathbf{b}$. and $\mathbf{c}$. 3D view of the section modeled; $\mathbf{d}$. Stereogram of the Salmon Red Syenite quarry with walls of section modeled in blue $(x)$ and green $(y)$; e. Joint frequency histogram of the quarry; $\mathbf{f}$. Raw block volume distribution using 3D Block Expert. 
The Salmon Red Syenite model (Fig. 3.20a, b and c) shows a lower amount of joints affecting the considered section. However, there are four joint sets affecting the rock and this is evidenced by the presence of vertical joints that are not orthogonal (Fig. $3.20 \mathrm{~d}$ and e). The raw block distribution shows that most of the blocks that this section is able to produce are between 3.5 and $6.5 \mathrm{~m}^{3}$ and larger than $8 \mathrm{~m}^{3}$ (Fig. $3.20 f)$.
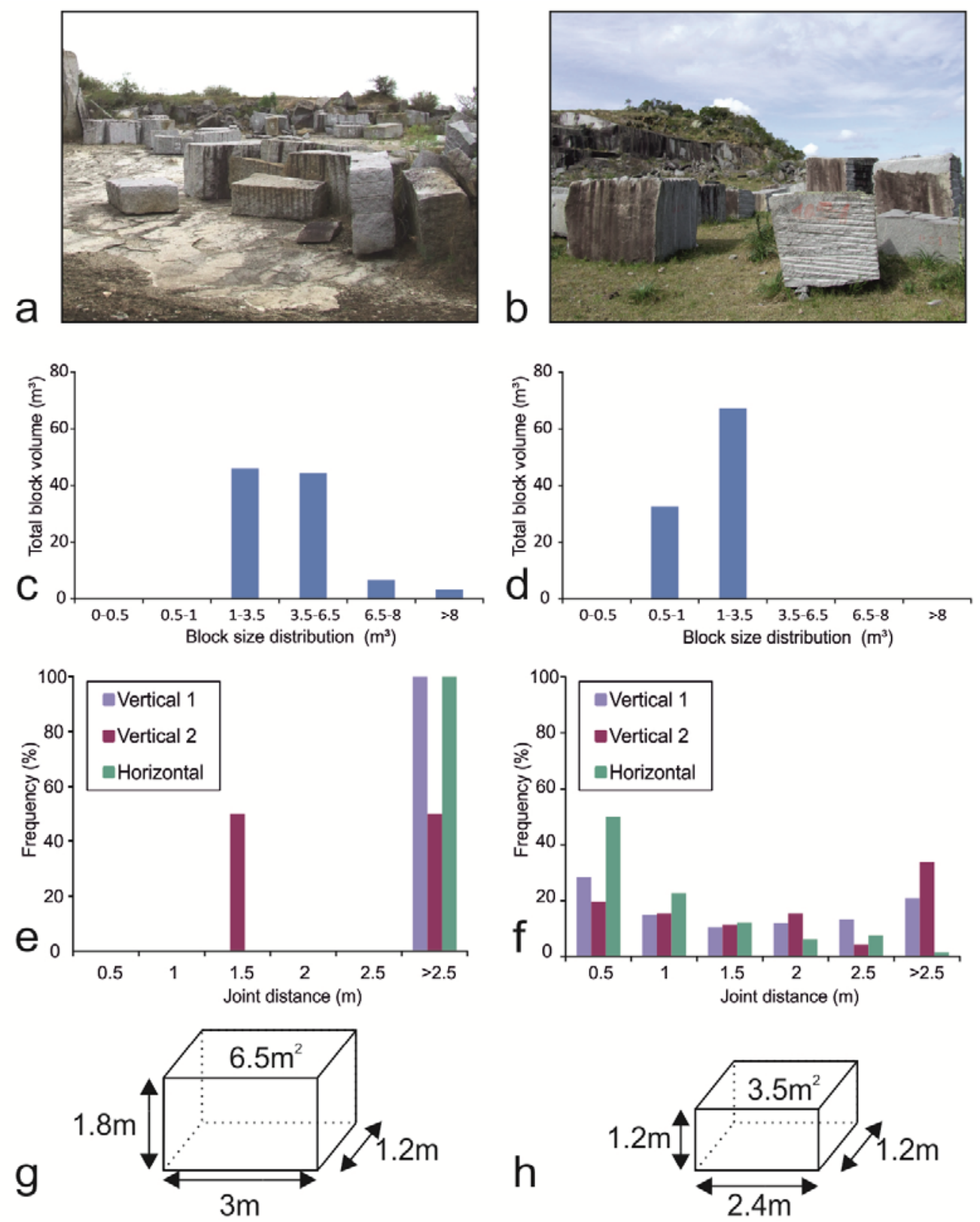

Fig 3.21: a., c., e. and g.: Cufré Granite quarry; b., d., f., and h.: Cerro Áspero Granite quarry number 192. a. and b. Block deposit; c. and d. Block sizes measured directly in the quarries; e. and f. Joint set distribution; $\mathbf{g}$. and $\mathbf{h}$. Plausible block sizes being obtained in the quarries studied. 
In two inactive quarries it was possible to measure the blocks remaining after the commercialization of the best ones. These are probably not the largest blocks that those quarries once produced (Fig. 3.21a and b). Most of the blocks in the Cufré Gray Blue quarry number 172 have a volume between 1 and $6.5 \mathrm{~m}^{3}$ (Fig. 3.21c) being larger than those in the Cerro Áspero quarry (Fig. 3.21d). This is in accordance with the joint set frequency measured for both quarries (Fig. 3.21e and f) and the results acquired by applying the method of Singewald (1992), Palmstrøm (1982, 1996 and 2001) and Sousa (2010) (Table 3.5 and Fig. 3.16). The application of these methods in the Cufré quarry leads to a block size that is extremely large, but in accordance with those sizes obtained using the program 3D Block Expert.

\subsubsection{Reserves and economic aspects}

The feasibility of the utilization of a deposit is determined not just by the dimensions of the deposit, but also by the economic demands and the deposit geometry, the stability of the country rock and the environmental conditions. Nevertheless, the decisive criterion is the dimension of the deposit. This is the area of occurrence of the rock, which actually meets the criteria of a marketable color and décor with exploitable block sizes.

For the calculation of maximal reserves, it is reasonable to assume a maximum depth of $100 \mathrm{~m}$. The reasons for not considering a greater depth are the stability of the rock massif, the economic costs of mining (e.g. transport costs, mine ventilation, safety of the staff) and rock mechanical problems (stress relief at greater depth can lead to intense fracturing, limiting the production of blocks). In stratiform deposits only the maximum depth of the strata is exploitable.

The exploration and evaluation of a dimensional stone deposit should consider, on the one hand, the maximum extension of the reserve. On the other hand, a minimum deposit volume is required. The opening and operation of a quarry demands a significant investment that is commonly covered by loans. The repayment period is between 10 years for movable goods and 30 years for immovable properties. For dimensional stones a 30 year repayment period is also normally accepted. The main 
reason is that this kind of resource is not listed on the stock exchange and their commercialization allows relatively low profit margins, but also due to its dependence on the prevailing taste (color and décor trends) and the trade cycles of the construction industry. In many countries the approval of operating plans for a quarry is based on these terms of repayment. For these reasons a minimum reserve volume should be calculated for a 30-year operation:

a. Scheduled annual production volume, taking into account non-productive periods (rainy seasons, freezing temperatures, impassable transportation routes, work regime).

b. Mining rate related to the joint systems inventory of the deposit.

C. Mining rate by squaring of the industrial blocks.

d. Mining rate considering the influence of lithological elements, which require a differentiation by taking into account the quality of the color and décor, which causes an impact on the revenue.

e. In addition, the rate of utilizable raw material for the fabrication of products that are not taken into account in the industrial usable blocks (e.g. small blocks for self-production, building bricks, paving materials).

\subsubsection{Granitoids}

The Uruguayan granitoids only show a small variety of the typical colors and décors of the internationally marketed granitoids. Most of the granitoids mined in the country are gray and medium-grained. This kind of hard dimensional stone is widespread worldwide and their décor is not so interesting for the international market. Nevertheless, three of them are interesting for the local and regional markets: Cufré, Maldonado and Cerro Áspero. The last one is possibly the most relevant due to its fine-grained texture, light gray color and excellent petrophysical properties.

\section{Cerro Áspero Granite}

The mining district Cerro Áspero Granite (U70) is located around $13 \mathrm{~km}$ west of the city of Rocha, in eastern Uruguay (Fig. 3.6). This district contains four quarries. Two 
of them are relatively large quarries (about 3,000 $\mathrm{m}^{2}$ ), which are presently inactive and the other two are still active but smaller (around $400 \mathrm{~m}^{2}$ ).

The rock is a fine- to medium-grained light gray granite with a relatively scarce occurrence of enclaves or veins. Its color and décor are very interesting for the international market, and since this rock has very good petrophysical qualities, it could compete for a place in the fine-grained gray granites sector.

The quarries are located in a granitic massif occupying an area of approximately 1.8 $\mathrm{km}^{2}$, which is expressed in the geomorphology as a hill, known as Cerro Áspero. The rock mined is characterized by a slight differentiation in grain size between fine- and medium-grained and a light gray color. Phenocrysts of plagioclase of white and light gray colors (up to $10 \mathrm{~mm}$ ) and black clots of biotite (up to five $\mathrm{mm}$ ) can eventually appear. Small mafic enclaves (up to three $\mathrm{cm}$ ) and narrow aplitic dikes (up to one $\mathrm{cm}$ ) are relatively rare. The décor and color of this granite is very homogeneous.

A boulder zone occurs at the top of the hill, with potential interest for the squaring of large blocks. There the yield of production is expected to be very high (around 90\%). The underlying weathered zone is around two meters thickness in the already opened quarries. This zone represents waste material for the dimensional stone industry, but it could be used for road paving and quarry filling after the mining ceases, thus reducing the cost of mining.

The most economically interesting sector is on the eastern side of this granitic massif, where one of the large inactive quarries is located (quarry number 192). The factors that make this sector more interesting are the fine grain size of the rock and the more favorable joint set distribution.

The distribution of the fine-grained area is around $90,000 \mathrm{~m}^{2}$. A minimum depth of 10 $\mathrm{m}$ can be easily reached taking into account the mining situation in the deposit. The raw production of this sector would be around 0.9 million $\mathrm{m}^{3}$. The yield of production inferred is $50 \%$ taking into account the blocks in the deposit and the waste material produced: $450,000 \mathrm{~m}^{3}$. The block size determined using the Singewald (1992); 
Palmstrøm (1982, 1996, 2001) and Sousa (2010) methods are 6.16 and $3.27 \mathrm{~m}^{3}$, the maximum and median, respectively. The sizes of the blocks in the deposit were measured (Fig. 3.18b and d) and they are smaller than those calculated using the cited methods. This is because they are the blocks left behind after the commercialization of the better ones, probably due to their inferior quality or smaller size.

Quarry number 193, the second largest quarry that is also currently inactive, is located in the western sector of the deposit. The rock is characterized by its mediumgrained texture and by the relatively higher frequency of joints. From the joint set distribution measurements, a fault-damage zone presumably affects this quarry, since the block sizes calculated using the Palmstrøm (2001) and Sousa (2010) methods are significantly smaller than those obtained for quarry number 192 (Table 4.5). In fact, this quarry produces small paving stones (around $0.04 \mathrm{~m}^{3}$ ) using unsophisticated technology.

\section{Cufré Gray Blue Granite}

The Cufré Gray Blue Granite deposit is located $16 \mathrm{~km}$ from Nueva Helvecia, in the Colonia department. The only quarry in the area is now inactive. The rock is a medium-grained gray granite with relatively frequent mafic enclaves and narrow aplitic dikes and a gentle foliation.

The previously described methods of Palmstrøm $(1982,1996,2001)$ and Sousa (2010) probably overestimate the plausible block sizes being mined in this deposit. This is due to the lack of visible joints affecting the rock massif in the observed quarry. Nevertheless, taking into account the real block size distribution measured in the blocks left out in the quarry, it is possible to assume a production of large blocks suitable for processing by gang saw blade.

The total outcrop area is around $15 \mathrm{~km}^{2}$, but the potentially most interesting zone is about eight hectares $\left(80,000 \mathrm{~m}^{2}\right)$, where the quarry was opened. The weathered zone is relatively narrow, around 1 to 1.5 meters that has to be considered waste 
material in the cost calculation. A minimum mining depth of 10 meters would lead to a total volume available for extraction of approximately $800,000 \mathrm{~m}^{3}$. A yield of $30 \%$ is possible for this deposit taking into account the structural elements, such as mafic enclaves, dikes and the low incidence of joints. From this $240,000 \mathrm{~m}^{3}$ to be produced, just around $10 \%$ will attain the requirements for exportable blocks.

\section{Maldonado Granite}

Maldonado district is located five $\mathrm{km}$ from the cities of Maldonado and Punta del Este. There are three active quarries, whose production consists mainly of small blocks with rough surfaces for the local market.

The rock is characterized by a dark gray color and a coarse-grained and foliated fabric. In the upper floor of the quarry the evidence for weathering is visible by the oxidation of the biotite clots as limonitic (orange) spots. Elongated mafic enclaves and aplitic dikes are aligned within the foliation and so homogeneously distributed that they act as part of the décor.

The district area is about $1.3 \mathrm{~km}^{2}$ and $5 \%$ of it could be possibly mined. Considering a mining depth of $10 \mathrm{~m}$ at several levels, the total volume would be $650,000 \mathrm{~m}^{3}$. The normal yield for this kind of mining in Uruguay is around $30 \%$. Since the requirements for this rock are not high, there is no limitation in respect to block size. This is very relevant because, even though the raw block size distribution modeled using the software 3D Block Expert show positive results (Fig. 3.19), the block size calculations using the Palmstrøm $(1982,1996,2001)$ and Sousa (2010) methods show very small block sizes $\left(<0.20 \mathrm{~m}^{3}\right.$ ) (Table 3.5$)$, making this rock incapable of entering international markets.

\section{Moskart Granite}

The Moskart Granite district is situated in the locality of Soca, about $50 \mathrm{~km}$ east of Montevideo. Several quarries were active in this district; however, at present there 
| Case study: Granitoids and syenitoids

are no mining activities. These activities were in close connection with more traditional farming activities (e.g. agriculture and livestock).

This district has an area of about $800,000 \mathrm{~m}^{2}$, being $10 \%$, located in different sectors of the district and interesting for mining. For a reserve calculation a mining depth of $10 \mathrm{~m}$ can be considered, even though it is possible to reach larger depths due to the stability of the rock massif. The yield of this dimensional granite is considered to be high (about 50\%) allowing for the absence of waste material in the areas surrounding the quarries. A probable reserve of $400,000 \mathrm{~m}^{3}$ is calculated for the Moskart Granite deposit.

From the block size calculations relatively small block sizes are expected. The most conservative method (Sousa, 2010) calculations determine a median block size of $1.8 \mathrm{~m}^{3}$.

Economic aspects of granitoid deposits

Granitoid deposits show a wide décor range and their petrophysical properties are very good. The prices for the gray granites range between 200 and $300 \mathrm{US} \$ / \mathrm{m}^{3} \mathrm{FOB}$ and the red granites between 300 and $400 \mathrm{US} \$ / \mathrm{m}^{3}$ FOB (Table 3.6).

From the reserve calculations, the Cerro Áspero Granite deposit could produce annualy up to $15,000 \mathrm{~m}^{3}$ of large-, medium- and small-sized blocks. These blocks could be traded with prices of around 200 to 300 US $\$$, depending on their sizes, color and décor quality. The annual quarry gross income would be between 3 to 4.5 million US\$.

For Cufré Gray Granite an annual production rate of $8,000 \mathrm{~m}^{3}$ is proposed. Considering an international price for this kind of dimensional stone of $200 \mathrm{US} \$ / \mathrm{m}^{3}$, the annual quarry gross income would be around 1,600,000 US\$.

An annual rate of $6,500 \mathrm{~m}^{3}$ is estimated for Maldonado Gray Granite deposit. The annular income taking a price of $200 \mathrm{US} \$ / \mathrm{m}^{3}$ would be $1,300,000$ US $\$$. 
Table 3.6: Summary of lithological, mineralogical and petrophysical aspects, deterioration risks and possible markets for Uruguayan commercial granites ( ${ }^{*}$ data from CEE-Uruguay no date, Q1, Q2 and

Q3 values from Mosch 2008). Abbreviations after Kretz (1983) except the ones marked with ${ }^{+}: A b$ : albite; Cam: Ca clinoamphibole; Aug: augite; Bt: biotite; Cal: calcite; Chl: chlorite; Stp: stilpnomelane;

Gr. Int. ${ }^{+}$: graphic intergrowth; Hbl: hornblende; Lm: limonite; Mc: microcline; Ms: muscovite; $\mathrm{Op}^{+}$: opaques; Or: orthoclase; PI: plagioclase; Qtz: quartz).

\begin{tabular}{|c|c|c|c|c|c|c|c|c|c|c|c|c|}
\hline \multirow{2}{*}{ Id } & \multirow{2}{*}{$\begin{array}{c}\text { Commercial } \\
\text { Name }\end{array}$} & \multirow{2}{*}{ Rock } & \multicolumn{3}{|c|}{ Décor } & \multicolumn{3}{|c|}{$\begin{array}{l}\text { Petrophysical } \\
\text { properties }\end{array}$} & \multirow{2}{*}{$\begin{array}{l}\text { Deterioration } \\
\text { risks }\end{array}$} & \multirow{2}{*}{ Uses } & \multirow{2}{*}{$\begin{array}{l}\text { Conclusion for } \\
\text { economical } \\
\text { aspect }\end{array}$} & \multirow{2}{*}{$\begin{array}{l}\text { Price rang } \\
\text { (US\$ FOB }\end{array}$} \\
\hline & & & $\begin{array}{c}\text { Modal analysis } \\
\text { (vol.-\%) }\end{array}$ & Color & Fabric & UCS & Flex. & Por. & & & & \\
\hline U87 & $\begin{array}{l}\text { Mahoma } \\
\text { Black }\end{array}$ & $\begin{array}{c}\text { Gabbro/ } \\
\text { norite }\end{array}$ & & Black & $\begin{array}{c}\text { MG, } \\
\text { HM-HT }\end{array}$ & - & - & - & sulfides & I, BF & internal market & $800-1200$ \\
\hline U49 & $\begin{array}{l}\text { Arapey } \\
\text { Black }\end{array}$ & Basalt & $\begin{array}{c}\text { 3Qtz, 40PI, } \\
\text { 31Aug, 17Lm, } \\
90 p\end{array}$ & Dark Gray & FG, HM & Q3 & - & $>$ Q3 & weathered & $\begin{array}{c}\text { I, BF / A, } \\
\text { W, P }\end{array}$ & internal market & $250-350$ \\
\hline U2 & Maldonado & Granite & $\begin{array}{c}51 \mathrm{Qtz}, 34 \mathrm{Mc} \\
10 \mathrm{PI}, 5 \mathrm{Bt}\end{array}$ & Gray (Pink) & $\begin{array}{l}\text { CG, } \\
\text { HM-HT }\end{array}$ & $>Q 3$ & $>Q 3$ & Q1 & - & $\mathrm{IA}$, all & $\begin{array}{l}\text { internal market, high } \\
\text { resistance paving }\end{array}$ & $200-300$ \\
\hline U4 & Chamangá & $\begin{array}{l}\text { Grano- } \\
\text { diorite }\end{array}$ & $\begin{array}{c}\text { 31Qtz, 9Or, 7Mc, } \\
38 \mathrm{PI}, 15 \mathrm{Bt}\end{array}$ & Gray & $\begin{array}{l}\text { MG, } \\
\text { HM-HT }\end{array}$ & Q3 & $>$ Q3 & $<Q 1$ & - & $\mathrm{IA}$, all & internal market & 200 \\
\hline U53 & $\begin{array}{l}\text { Cuchilla del } \\
\text { Perdido } \\
\text { Grey Blue }\end{array}$ & Granite & $\begin{array}{c}\text { 33Qtz, 26Or, } \\
29 \mathrm{Pl}, 10 \mathrm{Bt} \\
1 \text { Aug, } 1 \mathrm{Hbl}\end{array}$ & Gray & MG, HT & $>Q 3$ & $>Q 3$ & $<Q 1$ & - & IA, all & internal market & 200 \\
\hline U70 & $\begin{array}{l}\text { Cerro Áspero } \\
\text { or Grey Rocha }\end{array}$ & Granite & $\begin{array}{c}30 \mathrm{Qtz}, 36 \mathrm{Or}, \\
6 \mathrm{Mc}, 8 \mathrm{PI}, 12 \mathrm{Bt}, \\
7 \mathrm{Ms}, 1 \mathrm{Cal}\end{array}$ & Gray & $\begin{array}{l}\text { FG-MG, } \\
\text { HM }\end{array}$ & $>Q 3$ & - & Q3 & $\begin{array}{l}\text { carbonates, } \\
\text { limonitic } \\
\text { alteration }\end{array}$ & IA, all & $\begin{array}{c}\text { internal and } \\
\text { international market }\end{array}$ & $200-300$ \\
\hline U73 & $\begin{array}{l}\text { Cufré Grey } \\
\text { Blue }\end{array}$ & Granite & $\begin{array}{c}\text { 40Qtz, } 10 r \\
29 \mathrm{Mc}, 24 \mathrm{PI}, \\
6 \mathrm{Bt}\end{array}$ & Gray & MG, HT & - & - & $<Q 1$ & $\begin{array}{l}\text { limonitic } \\
\text { alteration }\end{array}$ & $\mathrm{IA}$, all & internal market & 200 \\
\hline U83 & Goñi & Granite & $\begin{array}{c}45 \mathrm{Qtz}, 28 \mathrm{Or}, \\
24 \mathrm{PI}, 3 \mathrm{Bt}\end{array}$ & Gray & $\begin{array}{l}\text { MG-CG, } \\
\text { HM-HT }\end{array}$ & - & - & - & - & $\mathrm{IA}$, all & $\begin{array}{l}\text { internal market, high } \\
\text { resistance paving }\end{array}$ & 200 \\
\hline U92 & $\begin{array}{l}\text { Pan de } \\
\text { Azúcar }\end{array}$ & $\begin{array}{l}\text { Qtz alkali } \\
\text { feldspar } \\
\text { syenite }\end{array}$ & $8 \mathrm{Qtz}, 800 \mathrm{O}, 11 \mathrm{Hbl}$ & Gray & CG, HM & - & - & - & - & IA, all & internal market & 200 \\
\hline U93 & Santa Teresa & Granite & $\begin{array}{c}18 \mathrm{Qtz}, 63 \mathrm{Mc} \\
10 \mathrm{PI}, 9 \mathrm{Bt}\end{array}$ & Gray & $\begin{array}{c}\text { vCG, } \\
\text { HM }\end{array}$ & - & - & - & - & $\mathrm{IA}$, all & internal market & 200 \\
\hline U94 & Isla Mala & Tonalite & $\begin{array}{c}\text { 42Qtz, } 1 \mathrm{Mc}, \\
53 \mathrm{PI}, 4 \mathrm{Bt}\end{array}$ & Gray & MG, HT & - & - & - & - & $\mathrm{IA}$, all & internal market & 200 \\
\hline U95 & $\begin{array}{l}\text { Garzón Gray } \\
\text { or Iguazú Gray }\end{array}$ & Granite & $\begin{array}{l}\text { 46Qtz, 32Or, } \\
6 \mathrm{Mc}, 13 \mathrm{PI}, 3 \mathrm{Bt}\end{array}$ & Gray & $\mathrm{FG}, \mathrm{HM}$ & $1>Q 3$ & - & - & - & IA, all & internal market & $200-300$ \\
\hline U7 & $\begin{array}{l}\text { Labradorita } \\
\text { Oriental or } \\
\text { Moskart }\end{array}$ & Granite & $\begin{array}{l}\text { 41Qtz, 46Mc, 8PI, } \\
\text { 1 Hbl, 2Festil,2Op }\end{array}$ & $\begin{array}{l}\text { Greenish } \\
\text { gray, } \\
\text { grayish } \\
\text { brown }\end{array}$ & $\begin{array}{l}\text { vCG, } \\
\text { HM }\end{array}$ & Q3 & $<Q 1$ & Q3 & microcracks & IA, all & internal market & $400-500$ \\
\hline U15 & $\begin{array}{l}\text { Salmon Red } \\
\text { or Guazubirá }\end{array}$ & $\begin{array}{l}\text { Qtz alkali } \\
\text { feldspar } \\
\text { syenite }\end{array}$ & $\begin{array}{c}\text { 12Qtz, 71Or, } \\
\text { 13PI, 2Hbl, 1Chl, } \\
\text { 1Festil }\end{array}$ & Pink salmon & $\begin{array}{c}\text { CG- } \\
\text { vCG, } \\
\text { HM }\end{array}$ & Q3 & Q3 & $>$ Q3 & pores & $\mathrm{IA}$, all & internal market & $400-500$ \\
\hline U46 & $\begin{array}{l}\text { Artigas } \\
\text { Pearl }\end{array}$ & $\begin{array}{l}\text { Alkali } \\
\text { feldspar } \\
\text { syenite }\end{array}$ & $\begin{array}{c}\text { 86Or, 5Pl, 4Hbl, } \\
\text { 5Festil }\end{array}$ & $\begin{array}{c}\text { Greyish blue } \\
\text { with pink } \\
\text { rims }\end{array}$ & $\begin{array}{l}\text { vCG, } \\
\text { HT }\end{array}$ & $<Q 1$ & $<Q 1$ & $>Q 3$ & $\begin{array}{l}\text { microcracks, } \\
\text { pores }\end{array}$ & $\mathrm{IA}$, all & internal market & $400-500$ \\
\hline U47 & $\begin{array}{l}\text { Violeta } \\
\text { Imperial }\end{array}$ & $\begin{array}{l}\text { Quartz } \\
\text { syenite }\end{array}$ & $\begin{array}{c}\text { 11Qtz, 67Or, 7PI, } \\
\text { 8Hbl, 1Lm, 1Aug, } \\
\text { 2Op, 3Festil }\end{array}$ & $\begin{array}{l}\text { Pale red- } \\
\text { violet and } \\
\text { brownish }\end{array}$ & CG, HM & Q3 & $<Q 1$ & $>Q 3$ & - & IA, all & internal market & $400-500$ \\
\hline U74 & $\begin{array}{l}\text { Caramel Pink } \\
\text { or La Paz }\end{array}$ & Granite & $\begin{array}{l}\text { 25Qtz, 60Mc, } \\
\text { 7Pl, 7Bt, } 1 \mathrm{Hbl}\end{array}$ & Pink and red & $\begin{array}{c}\text { vCG, } \\
\mathrm{HT}\end{array}$ & Q3* & - & Q1 & - & IA, all & internal market & 300 \\
\hline U76 & $\begin{array}{l}\text { Guazunambí, } \\
\text { Montevideo } \\
\text { or Iguazú }\end{array}$ & Granite & $\begin{array}{c}\text { 27Qtz, 15Or, } \\
\text { 16Mc, 36PI, } \\
\text { 4Bt, 1Aug, 1Cal }\end{array}$ & $\begin{array}{l}\text { Red and } \\
\text { reddish } \\
\text { brown }\end{array}$ & MG, HM & $1 \mathrm{Q}^{*}$ & - & Q3 & carbonates & $\mathrm{IA}$, all & $\begin{array}{l}\text { eventually } \\
\text { international market }\end{array}$ & $300-400$ \\
\hline U88 & Mahoma & Granite & $\begin{array}{c}\text { 41Qtz, 7Or, } \\
\text { 15Mc, 30PI, } \\
6 \mathrm{Bt}\end{array}$ & Pink & MG, HM & 1 Q2* & - & Q2 & - & IA, all & $\begin{array}{l}\text { eventually } \\
\text { international market }\end{array}$ & $300-400$ \\
\hline
\end{tabular}

The Moskart Granite is with no doubt the exception in this group, since its décor is very unique and it is possible to square large blocks making this rock very competitive. Its price is between 400 and $500 \mathrm{US} \$ / \mathrm{m}^{3}$ FOB (Table 3.6). The yearly production rate would be $13,000 \mathrm{~m}^{3}$. Considering that $10 \%$ of this production are exportable blocks and taking the price in $\mathrm{m}^{3}$ of $450 \mathrm{US} \$$, an exportation income of 585,000 US $\$$ should be expected. 


\subsubsection{Syenitoids}

Uruguayan syenitoids are mined in two districts in the Sierra de las Ánimas Complex. Since the start of production at the beginning of the $20^{\text {th }}$ century and before the economic crisis in Uruguay in 2002, the production took place in small quarries offering a diverse color spectrum. In the southern mining area (Pan de Azúcar Piriápolis) large quarries were located in the Cerro Pan de Azúcar and Sierra de las Palmas hills with a capacity to provide material for export. During the 1980's and 1990s, mining activity was concentrated in small quarries in the northern mining district (the Camino del Amigo-Estancia Guazubirá). Nowadays all quarries are inactive.

The color and décor of the syenitoids are a major controlling parameter of the deposit. They are related to the amount and grain size of the feldspars, and the color development related to hydrothermal alteration.

\section{Artigas Pearl}

This deposit shows intensive hydrothermal alteration and comprises a total exposure of $4.6 \mathrm{~km}^{2}$. Considering the outcrop conditions and the geological findings, an area of $90,000 \mathrm{~m}^{2}$ can be mined. Due to the intrusion of effusive rocks appearing as dikes, a decrease of $30 \%$ in the possible reserve volume has to be considered. The high rate of waste material due to the presence of dikes (mainly quartz alkali feldspar trachyte) is a consequence of their geometry (dip and strike) and spatial occurrence.

Not included in this estimation is the waste material of the weathered section on the top of the deposit. Individual boulders are exposed in this section and are of industrial value, as long as they are not affected by joints. However, the amount of the waste material to be removed in the weathered section below the boulder zone is calculated to be around $90 \%$.

The joint distance measured thus far within the outcrops of the deposit indicates a decrease of the joint distance with the depth (see Table 3.5). At what depth the rock 
(Artigas Pearl Syenite) is weathered and the joints opened, is still an uncertainty. Hence, only boulders at the top of the hill and in the upper floor can be mined at present. Average block sizes of 38.1 and $2.14 \mathrm{~m}^{3}$ (median) were determined for the boulder zone and upper floor, respectively. A new exploitation of this upper floor should be geared to the geometry of the surface. The mining rate of the boulder zone is estimated to be very high (around 50\%), being drastically lower in the upper floor by around $10 \%$. Considering that the boulder zone extends for an area of $240,000 \mathrm{~m}^{2}$ and the average height is $5 \mathrm{~m}$, the probable reserve of this zone taking into consideration the yield of the mining would be around $600,000 \mathrm{~m}^{3}$. The upper floor could be mined in a similar area and at similar depths, but as the yield is lower here a probable reserve of $120,000 \mathrm{~m}^{3}$ is expected.

\section{Pan de Azúcar White}

In the southern mining district white syenite crops out in the hill Cerro Pan de Azúcar. Commercially it is known as Pan de Azúcar White, but the quarry from where it was mined is now inactive. This dimensional stone is characterized by its light gray color and coarse-grained texture. Even though this rock shows feldspar substitutions, the absence of red stain is related to the lack of hematite in the pores of the feldspar, probably due to the lack of hydrothermal influence.

The surface distribution of this deposit is unknown, due to the steep slope of the hill and the lush vegetation that covers the outcrops. A minimum area of $21,000 \mathrm{~m}^{2}$ is determined by the extent of the inactive quarry and its surroundings. Considering a safe mining depth of $10 \mathrm{~m}$, the probable reserves would be about $210,000 \mathrm{~m}^{2}$. With a mining yield of $50 \%$, a block production of $105,000 \mathrm{~m}^{3}$ is expected.

\section{Guazubirá Syenites: Salmon Red and Violeta Imperial}

In the northern mining district the pink and light red colors dominate (Salmon Red Syenite). The mining district has an area of about $5 \mathrm{~km}^{2}$. Typical for this district are numerous wide fault zones as indicated by the valleys. Former mining in the center or nearby these zones produced only ballast and rubble (aggregates). 
The joint set distribution has been measured and analyzed using the previously described methods of Palmstrøm (1982, 1996, 2001) and Sousa (2010). A deposit (quarry number 075 ) for production of dimensional stone localized in a fault zone has a median block size of just $0.4 \mathrm{~m}^{3}$. In another deposit (quarry number 079 ) outside the fault zones a median block volume of $4.89 \mathrm{~m}^{3}$ is calculated. Considering the tectonic setting the potential mining area is reduced to almost $30 \%$ of the whole deposit: $1.5 \mathrm{~km}^{2}$. The waste material would be considered a cost factor, but not as a decrease in the reserves.

For a realistic calculation of the deposit reserves, quarry 079 will be used as an example. Its dimensions are around $700 \times 300 \mathrm{~m}$, therefore an area of 210,000 $\mathrm{m}^{2}$. Using a conservative mining depth of $10 \mathrm{~m}$ and a mining yield of $60 \%$, the reserves would be about $1,260,000 \mathrm{~m}^{3}$. The yield proposed is based on the international experience and the model of a section of quarry 075 using 3D Block Expert (Fig. $3.20)$.

A theoretical annual production capacity of $42,000 \mathrm{~m}^{3}$ is calculated for a mining duration of 30 years in the quarry 079 . Oscillations in the world market must be considered. It is also necessary to evaluate the considered area using economical geophysical methods in order to determine the distribution and magnitude of the waste material to be removed.

Regarding the cost of mining an optimization can be proposed using two different mining procedures. One procedure would be to use a greater surface area for mining at lower depth, and the second the construction of numerous mining levels in order to reach greater depths in a smaller area. The influence of volcanic rocks occurring at the rim of the deposit cannot be easily evaluated. It cannot be excluded that the deposit is affected by dikes, veins or sills.

The small deposit of Violeta Imperial Syenite is a special case in regards to décor, where it shows smaller and narrow alkali feldspars that partially exhibit an interstitial fabric and a red violet color. Its dimension is less than $10,000 \mathrm{~m}^{2}$. Considering a 
| Case study: Granitoids and syenitoids

mining depth of $10 \mathrm{~m}$ and a rate of $60 \%$, the possible reserves of this deposit are calculated to be $60,000 \mathrm{~m}^{3}$. A production would be possible as a special target and would only be economically viable in combination with the main production of the pink colored syenite.

Economic aspects of syenitoid deposits

The syenitoid group may also have a good position on the international market, since the range in décor for these rocks is quite uncommon and very pleasing to the eye. As the petrophysical properties are not a limiting factor for their commercialization, these rocks could be sold at prices between 400 and 500 US $\$ / m^{3}$ FOB. An annual production of $24,000 \mathrm{~m}^{3}$ is proposed for the Artigas Pearl Syenite. The attainable average market price of $500 \mathrm{US} \$ / \mathrm{m}^{3}$ would account for 12 million US $\$$ per year.

For the Pan de Azúcar Syenite an annual production of $3,500 \mathrm{~m}^{3}$ can be calculated. At market prices for white granitic stones of $200 \mathrm{US} \$ / \mathrm{m}^{3} \mathrm{FOB}$, the annual income of its mining would be 700,000 US\$.

Due to its color and décor the Salmon Red Syenite could be easily placed on the market in the category of red granitic dimensional stones. Its fabric makes it particularly interesting, because it gives the impression of being optically homogeneous. Taking an average price level of 500 US\$ per $\mathrm{m}^{3}$ and an average rate of $50 \%$ of exportable industrial blocks would result in an annual amount of $10,500,000$ US\$.

For the Violeta Imperial deposit the annual production of 2,000 $\mathrm{m}^{3}$ can be calculated. The prices for this kind of colored granitic stones average $450 \mathrm{US} \$ / \mathrm{m}^{3} \mathrm{FOB}$, allowing an annual profit of 900,000 US\$.

\subsection{Conclusions}

The Uruguayan commercial granites can be classified by their petrography and geochemistry into mafic rocks, granitoids and syenitoids. For the last two groups a 
| Case study: Granitoids and syenitoids

characterization has been carried out considering their color and décor, their petrophysical properties and their economically profitable occurrence in the field (deposit).

The only mafic rock deposits successfully mined in Uruguay today as dimensional stone are the dolerites. They will not be described in this chapter since they have been considered in chapter 2 .

Table 3.7: Worldwide known commercial granites (Source: Börner and Hill 2010 except values marked with * Strohmeyer 2003).

\begin{tabular}{|c|c|c|c|c|c|c|c|c|c|}
\hline Sample & Origin & Lithology & Décor & Petrography (\%) & $\begin{array}{l}\text { Density } \\
\left(\mathrm{g} / \mathrm{cm}^{3}\right)\end{array}$ & $\begin{array}{l}\text { UCS } \\
\text { (MPa) }\end{array}$ & $\begin{array}{c}\text { Flexural } \\
\text { Strength } \\
\text { (MPa) }\end{array}$ & $\begin{array}{l}\text { Water } \\
\text { absoption } \\
\text { (wt\%) }\end{array}$ & Reference object \\
\hline $\begin{array}{l}\text { Padang Hell or } \\
\text { G3533 }\end{array}$ & r China & Granite & Light gray, FG & & 2.63 & 117.6 & 15.3 & $0.36 ?$ & \\
\hline Kuru Grey & Finland & Granite & $\begin{array}{l}\text { Middle gray, } \\
\text { FG }\end{array}$ & $\begin{array}{c}\text { 35Qtz, } 36 \mathrm{Or}, 21 \mathrm{PI}, \\
8 \mathrm{Acc}\end{array}$ & 2.66 & 294-297 & $24.5-25$ & 0.11 & \\
\hline $\begin{array}{c}\text { Serizzo } \\
\text { Antigorio* }\end{array}$ & Italy & Gneiss & $\begin{array}{l}\text { Dark gray- } \\
\text { black, MG }\end{array}$ & $\begin{array}{c}32 \mathrm{Qtz}, 11 \mathrm{Kfs}, 38 \mathrm{PI}, \\
13 \mathrm{Bt}, 5 \mathrm{Ms}, 1 \mathrm{Chl} \\
\text { acc: } \mathrm{Ep}, \text { Tur }^{*}\end{array}$ & $2.72^{*}$ & $169^{*}$ & $14-17$ & $0.34-0.39$ & \\
\hline Bianco Sardo & Italy & Granite L & Light gray, CG & & $2.58-2.62$ & $159-213$ & $12-14$ & 0.58 & Kölnmesse, Cologne \\
\hline Verde Butterfly & Brazil & Monzonite & Green, vCG & $\begin{array}{l}\text { 50Or-pert, 30Olg, } \\
\text { 12Qtz, 8Opx }\end{array}$ & 2.67 & 101 & 9 & 0.15 & \\
\hline Flash Blue & India $A$ & Anorthosite & e $\begin{array}{c}\text { Dark green, } \\
\text { vCG }\end{array}$ & & & 65 & 16 & 0.4 & \\
\hline $\begin{array}{c}\text { Rosa Santa } \\
\text { Eulalia }\end{array}$ & Portugal & Granite & $\begin{array}{c}\text { Gray-Pink, } \\
\text { MG-CG }\end{array}$ & & 2.64 & $165-167$ & 20 & 0.16 & \\
\hline Rosavel & Spain & $\begin{array}{l}\text { Quarz- } \\
\text { Syenite }\end{array}$ & Pink, vCG & & $2.63-2.65$ & $62-63$ & $17-18$ & 0.7 & Hoto-Tower, Zagreb, Croacia \\
\hline $\begin{array}{l}\text { Marrom } \\
\text { Gaucho }\end{array}$ & Brazil & Syenite & Brown, MG & & $2.60-2.65$ & $158-204$ & 10 & & Washington Plaza in Paris \\
\hline
\end{tabular}

The fine-grained gray granite varieties Cerro Áspero and Garzón Gray are similar in décor to the Padang Light Granite (G633/G3533) (China) and Kuro Gray (Finland). The petrophysical properties of the Uruguayan fine-grained gray granites are between those of these two internationally known granites (Table 3.7). Cerro Áspero Granite show higher UCS values as Padang Light, as well as slightly lower water absorption values. Oxidation of biotite under normal weathering conditions has an adverse effect on the color (by the staining of surrounding minerals) and in the rock stability. In the Cerro Áspero Granite no accumulation of iron hydroxide occurs due to the extremely low capillary water uptake. This characteristic places this granite in a better market position in comparison to the Padang Light, which is one of the most commercialized light gray and fine-grained granites. In its porosity and pore-related petrophysical properties, the Cerro Áspero Granite is comparable to the Kuro Gray Granite from Finland. 
The Cerro Áspero Granite deposit can provide material for the dimensional stone industry as well as directly for the building sector. The large blocks can be cut with a gang saw blade for the production of polished slabs for wall cladding. The small- and medium-sized blocks provide material for flagstone and other products using normal saw blades or by simple handwork.

The color and décor of the Cufré Gray Blue Granite is not particularly interesting for the international market, but the rock can be commercialized at local and regional markets. Oxidation of the mafic enclaves and biotite clots with the development of orange colored limonitic spots has been observed in the quarry. This phenomenon has not been seen in polished slabs used for outdoor façades (e.g. Torre de Antel, see Fig. 3.1a). The stone has a very high content of quartz (40\%), and thus a good stability as a polished surface. Due to the presence of a foliation, mafic enclaves and biotite clots, the décor of this rock will vary within a block. The entire block needs to be cut in order to classify the finished product according to the décor (i.e. the presence or absence of heterogeneities that will determine the products quality). Taking into consideration these facts and also the low porosity and low capillary water absorption, the Cufré Gray Blue can substitute for high quality imported stones for indoor and outdoor floor and façade cladding.

Maldonado Gray Granite is comparable in décor and petrophysical properties with the Italian Serizzo Antigorio gneiss. The Uruguayan granite shows higher strength values and lower water uptake. An optimization of the mining of this commercial granite could eventually lead to a higher production of larger blocks, which could place this granite on the international market.

Moskart or Soca Granite has similarities in décor (the greenish-gray color, the very coarse-grained texture and the occasional iridescent feldspar) with the Flash Blue Granite from India and the Verde Butterfly from Brazil. The compressive strength is higher in the Uruguayan Granite and its flexural strength and water uptake values are in between both international granites. These characteristics make the Uruguayan granite a good competitor against the Indian and Brazilian granites. Due to its very 
coarse-grained texture and the presence of microcracks, the best method for mining this dimensional stone has proven to be the diamond wire saw. These characteristics, together with the relatively low values of its petrophysical properties, make a previous treatment of the slabs necessary in order to ensure their stability (e.g. chemical treatment to prevent water infiltration). Examples of this assessment are illustrated in Figure 3.22a, where a step of a stone staircase broke due to the low flexural resistance of this stone. In Figure 3.22b an outdoor façade cladding with precipitated calcite in the microcracks is shown, probably due to the remobilization of the cement material. Despite these application problems the Moskart Granite was commercialized on the international market during the last decade of the $20^{\text {th }}$ century.

The décor of the Uruguayan colored syenitoids is so unique that there are no rocks to compare them with. The red granites, on the other hand, can be compared with numerous rocks. The equigranular facies of the La Paz Granite can be compared to the Rosa Santa Eulalia, a granite from Portugal; the porphyritic facies with the Rosavel Granite from Spain and the Guazunambí Granite with the Marrom Gaucho Syenite from Brazil. Their petrophysical properties are comparable to those of the international granites, but the compressive strength is clearly higher than the Rosavel quartz-syenite.

The appearance of numerous open pores in polished slabs of the Artigas Pearl Syenite, as well as in the deposit, is a factor to consider for its application. A coating will be necessary before its utilization as a working table or high quality flooring slabs. The use as a funerary monument is limited due to the high requirements in this sector. Basically, the application of this rock in the heavy duty sector has to be carefully considered, since it has relatively low petrophysical values in comparison to those of the syenite-monzonite groups of Mosch (2008). 

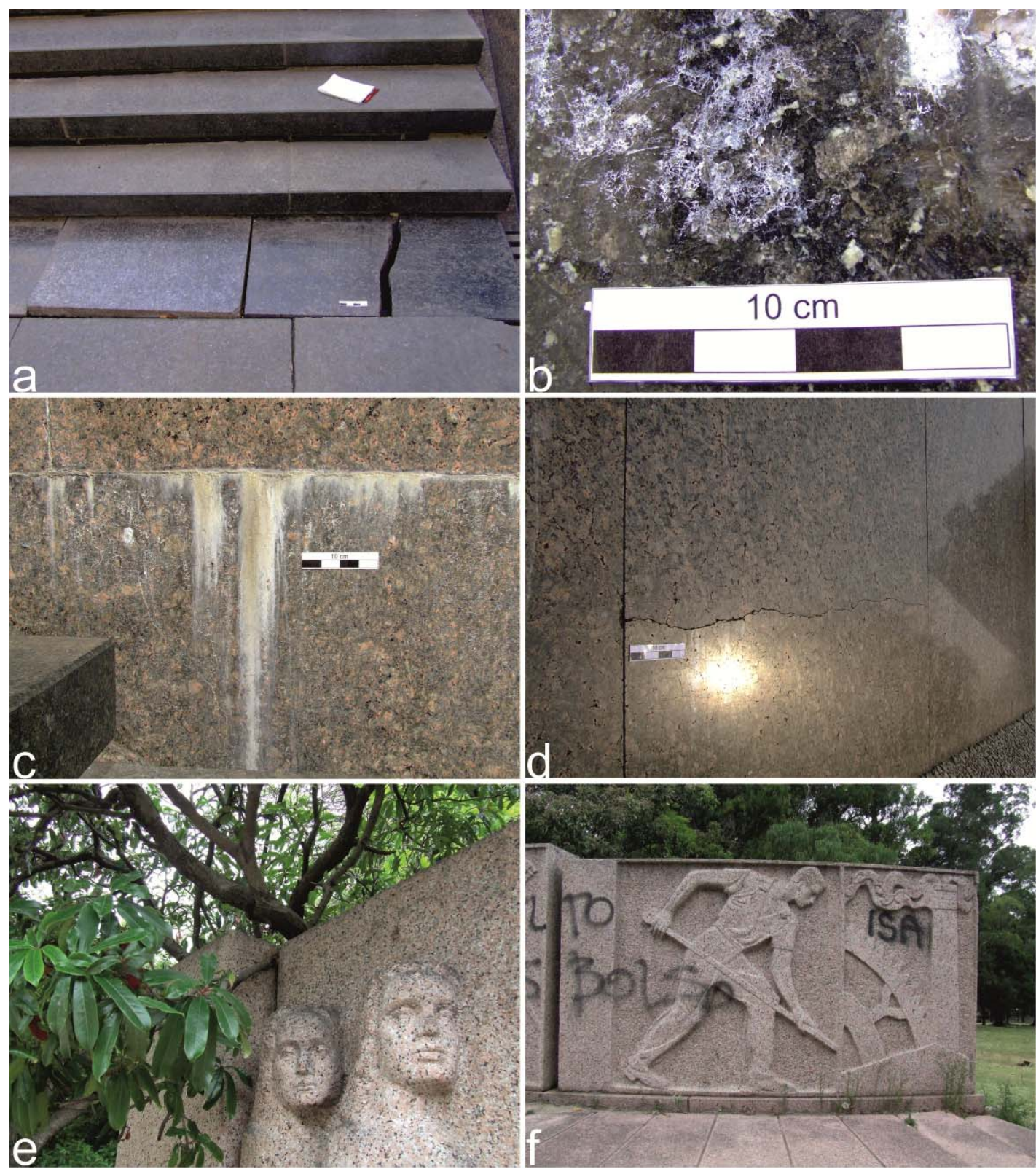

Fig. 3.22: Damages. a. Moskart Granite broken floor cladding due to the low flexural strength of this rock; b. Moskart Granite outdoor façade cladding with calcite precipitated in the microcracks, probably by the remobilization of the cement material; c. Artigas Pearl Syenite outdoor cladding; precipitation of calcite from the cement in the joint between two slabs; d. Artigas Pearl outdoor monument cladding with a crack presumably posterior to the placement. Note the microcracks and little pores homogeneously distributed in the entire polished slab; e. La Paz Granite urban monument affected by biomechanical deterioration due to the growth of a tree; $f$. The same monument shows anthropogenic deterioration (graffiti).

The Salmon Red Syenite is in demand on the international market because of its color and décor, where it can be used in combination with rough surfaces and more dark red rocks for indoor and outdoor flooring slabs. Comparing the petrophysical values with the syenite-monzonite group investigated by Mosch (2008), this syenite has a very good position, allowing its use in sophisticated construction locations such 
as façades and countertops. Pore formation can be problematic in this dimensional stone, so that special attention has to be taken in the posterior industrial process (cutting and polishing). No negative aspects are known in regards to the weathering behavior.

The Pan de Azúcar White Syenite is comparable in décor to the Bianco Sardo from Italy. This rock could be interesting for the international market, as long as it can be extracted in industrially utilizable blocks. It could occupy a segment in the market, because the color "white" in hard rocks is not very common. In this sector, aplites and gneisses are offered, which very often show problems with posterior alteration accompanied by the formation of visible limonite.

Uruguayan syenitoids have been in use for several decades in the harbor facilities of Argentina and Uruguay. They have a high salinity resistance as well as a high resistance against applied loads (wash of the waves). This allows the application of small blocks on the international market for sectors that need high chemical resistant materials. With this special utilization, the deposits would be more competitive and have a better mining yield, since the high proportion of waste material is composed of small blocks. The waste material could be minimized by the production of aggregates parallel to the production of large blocks.

In summary, the color and décor, together with the petrophysical properties of the Uruguayan commercial granites places them in a very good position to compete with internationally known granitic stones. The fine-grained gray granites are particularly interesting because they show very good petrophysical properties that allow their use in practically all types of building applications. Their color and décor make the commercialization of these rocks relatively independent of the changing fashion demands of the market. 
| Case study: Granitoids and syenitoids

Appendix

Table A.3.1: Petrophysical properties: density, porosity, water absorption (W.A.).

\begin{tabular}{|c|c|c|c|c|c|c|c|c|c|c|}
\hline Rock/Test & ID & $\begin{array}{c}\text { Bulk } \\
\text { density } \\
\left(\mathbf{g} / \mathbf{c m}^{3}\right)\end{array}$ & $\begin{array}{c}\text { Matrix } \\
\text { density } \\
\left(\mathbf{g} / \mathbf{c m}^{3}\right)\end{array}$ & $\begin{array}{c}\text { Porosity } \\
\text { (\%) }\end{array}$ & $\begin{array}{c}\text { Average } \\
\text { pore } \\
\text { radii } \\
(\mu \mathrm{m})\end{array}$ & $\begin{array}{c}\text { Most } \\
\text { abundant } \\
\text { pore radii } \\
(\mu \mathrm{m})\end{array}$ & $\begin{array}{c}\text { Capilarry } \\
\text { W.A. } \\
\left(\mathrm{kg} / \mathrm{m}^{2} \mathbf{h}^{0.5}\right)\end{array}$ & $\begin{array}{c}\text { Forced } \\
\text { W.A. } \\
\text { (wt\%) }\end{array}$ & $\begin{array}{l}\text { Unforced } \\
\text { W.A. } \\
\text { (wt\%) }\end{array}$ & S-value \\
\hline Arapey Black Basalt & U49 & 2.94 & 2.96 & 0.98 & 0.032 & 0.021 & 0.16 & 0.33 & 0.28 & 0.86 \\
\hline Maldonado Gray Granite & U2 & 2.64 & 2.64 & 0.48 & 0.051 & 0.053 & 0.10 & 0.18 & 0.17 & 0.91 \\
\hline Chamangá Gray Granite & U4 & 2.69 & 2.69 & 0.27 & 0.077 & 0.021 & 0.10 & 0.10 & 0.07 & 0.70 \\
\hline Cuchilla del Perdido Granite & U53 & 2.72 & 2.73 & 0.31 & 0.070 & 0.084 & 0.11 & 0.12 & 0.09 & 0.80 \\
\hline Cerro Áspero Gray Granite & U70 & 2.65 & 2.67 & 0.80 & 0.090 & 0.133 & 0.11 & 0.30 & 0.27 & 0.89 \\
\hline Moskart Granite & U7 & 2.66 & 2.67 & 0.58 & 0.070 & 0.008 & 0.07 & 0.22 & 0.19 & 0.89 \\
\hline Salmon Red Syenite & U15 & 2.61 & 2.64 & 0.86 & 0.042 & 0.084 & 0.82 & 0.33 & 0.30 & 0.91 \\
\hline Artigas Pearl Syenite & U46 & 2.64 & 2.68 & 1.15 & 0.077 & 0.008 & 0.19 & 0.44 & 0.40 & 0.93 \\
\hline Violeta Imperial Syenite & U47 & 2.62 & 2.66 & 1.34 & 0.057 & 0.335 & 0.22 & 0.51 & 0.43 & 0.83 \\
\hline
\end{tabular}

Table A.3.2: Petrophysical properties: Thermal expansion, water vapor diffusion and ultrasound.

\begin{tabular}{|c|c|c|c|c|c|c|c|c|c|c|c|c|}
\hline \multirow{2}{*}{$\begin{array}{l}\text { Rock/Test } \\
\text { Direction }\end{array}$} & & \multicolumn{5}{|c|}{ Thermal Expansion $\left(10^{-6} \mathrm{~K}^{-1}\right)$} & \multicolumn{3}{|c|}{$\begin{array}{l}\text { Water vapor } \\
\text { diffusion }\end{array}$} & \multicolumn{3}{|c|}{ Ultrasound $(\mathrm{km} / \mathrm{s})$} \\
\hline & & $\mathbf{x}$ & $\mathbf{y}$ & $\mathbf{z}$ & $\begin{array}{c}\text { Average } \\
\text { Value }\end{array}$ & $\begin{array}{c}\text { nisotropy } \\
(\%)\end{array}$ & $\mathbf{x}$ & $\mathbf{y}$ & $\mathbf{z}$ & $\mathbf{x}$ & $\mathbf{y}$ & $\mathbf{z}$ \\
\hline Arapey Black Basalt & U49 & 6.21 & 6.03 & 5.75 & 6.00 & 7 & -355 & -781 & -1251 & 5.73 & 5.88 & 5.41 \\
\hline Maldonado Gray Granite & U2 & 7.3 & 7.76 & 8.04 & 7.70 & 9 & 83 & 228 & 269 & 5.15 & 5.73 & 5.31 \\
\hline Chamangá Gray Granite & U4 & 8.35 & 7.93 & 7.30 & 7.86 & 13 & 1232 & 851 & 1099 & 5.73 & 5.22 & 5.40 \\
\hline Cuchilla del Perdido Granite & U53 & 7.39 & 7.88 & 8.28 & 7.85 & 11 & 528 & 456 & 459 & 5.85 & 5.62 & 5.57 \\
\hline Cerro Áspero Gray Granite & U70 & 6.94 & 6.74 & 6.50 & 6.73 & 6 & n.d. & n.d. & n.d. & 4.27 & 4.08 & 3.38 \\
\hline Moskart Granite & U7 & 7.78 & 9.47 & 8.46 & 8.57 & 18 & 374 & 526 & 358 & 5.83 & 5.57 & 5.46 \\
\hline Salmon Red Syenite & U15 & 6.27 & 6.34 & 6.96 & 6.52 & 10 & 1508 & 1182 & 1046 & 5.15 & 5.18 & 5.03 \\
\hline Artigas Pearl Syenite & U46 & 5.74 & 6.79 & 6.18 & 6.23 & 15 & 442 & 1017 & 588 & 5.08 & 5.03 & 4.88 \\
\hline Violeta Imperial Syenite & U47 & 6.45 & 6.45 & 7.16 & 6.69 & 10 & 861 & 525 & 797 & 5.59 & 5.45 & 5.27 \\
\hline
\end{tabular}


| Case study: Granitoids and syenitoids

Table A.3.3: Petrophysical properties: uniaxial compressive strength, modulus of elasticity and indirect tensile strength.

\begin{tabular}{|c|c|c|c|c|c|c|c|c|c|c|}
\hline \multirow{2}{*}{$\begin{array}{l}\text { Rock/Test } \\
\text { Direction }\end{array}$} & \multirow[t]{2}{*}{ ID } & \multicolumn{3}{|c|}{$\begin{array}{l}\text { Uniaxial Compressive } \\
\text { Strength (MPa) }\end{array}$} & \multicolumn{3}{|c|}{ Modulus of elasticity (GPa) } & \multicolumn{3}{|c|}{$\begin{array}{l}\text { Indirect Tensile Strength } \\
\text { (MPa) }\end{array}$} \\
\hline & & $\mathbf{x}$ & y & z & $\mathbf{x}$ & $\mathbf{y}$ & $\mathbf{z}$ & $\mathbf{x}$ & y & $\mathbf{z}$ \\
\hline Arapey Black Basalt & U49 & $226 \pm 19$ & $229 \pm 17$ & $230 \pm 9$ & $16.1 \pm 3.8$ & $23.3 \pm 6.2$ & $20.2 \pm 6.1$ & $10.6 \pm 2.0$ & $12.7 \pm 3.1$ & $10.1 \pm 1.1$ \\
\hline Maldonado Gray Granite & U2 & $191 \pm 9$ & $187 \pm 21$ & $189 \pm 21$ & $16.4 \pm 5.8$ & $15.7 \pm 6.1$ & $16.9 \pm 2.2$ & $9.1 \pm 1.6$ & $8.9 \pm 2.3$ & $6.8 \pm 1.9$ \\
\hline Chamangá Gray Granite & U4 & $175 \pm 18$ & $206 \pm 14$ & $181 \pm 21$ & $22.6 \pm 5.4$ & $32.9 \pm 12.8$ & $23.9 \pm 5.5$ & $8.6 \pm 1.2$ & $9.4 \pm 2.3$ & $10.6 \pm 2.2$ \\
\hline Cuchilla del Perdido Granite & U53 & $203 \pm 13$ & $196 \pm 16$ & $197 \pm 13$ & $17.4 \pm 6.5$ & $22.7 \pm 12.1$ & $11.9 \pm 4.8$ & $9.8 \pm 2.7$ & $10.6 \pm 1.3$ & $10.3 \pm 2.3$ \\
\hline Cerro Áspero Gray Granite & U70 & $190 \pm 31$ & - & $197 \pm 14$ & $17.2 \pm 3.1$ & - & $17.4 \pm 6.1$ & $10.7 \pm 1.8$ & $12.6 \pm 2.7$ & - \\
\hline Moskart Granite & U7 & $162 \pm 14$ & $168 \pm 18$ & $181 \pm 14$ & $17.2 \pm 4.4$ & $13.7 \pm 4.2$ & $15.2 \pm 3.2$ & $8.7 \pm 1.2$ & $6.6 \pm 2.1$ & $7.8 \pm 1.4$ \\
\hline Salmon Red Syenite & U15 & $177 \pm 11$ & $159 \pm 23$ & $193 \pm 7$ & $26.4 \pm 11.6$ & $17.9 \pm 6.3$ & $21.0 \pm 4.2$ & $8.8 \pm 2.3$ & $8.7 \pm 1.8$ & $9.1 \pm 1.3$ \\
\hline Artigas Pearl Syenite & U46 & $139 \pm 4$ & $138 \pm 12$ & $136 \pm 2$ & $18.4 \pm 5.4$ & $19.4 \pm 4.8$ & $20.7 \pm 13.4$ & $5.2 \pm 1.1$ & $6.4 \pm 1.2$ & $5.7 \pm 1.0$ \\
\hline Violeta Imperial Syenite & U47 & $167 \pm 17$ & $169 \pm 14$ & $168 \pm 14$ & $13.9 \pm 4.0$ & $18.2 \pm 6.4$ & $16.1 \pm 4.8$ & $7.5 \pm 1.6$ & $7.9 \pm 1.8$ & $7.2 \pm 1.3$ \\
\hline
\end{tabular}

Table A.3.4: Petrophysical properties: flexural strength, abrasion strength and breaking load at the

\begin{tabular}{|c|c|c|c|c|c|c|c|c|}
\hline \multirow{2}{*}{$\begin{array}{l}\text { Rock/Test } \\
\text { Direction }\end{array}$} & \multirow[t]{2}{*}{ ID } & \multicolumn{3}{|c|}{ Flexural Strength (MPa) } & \multicolumn{3}{|c|}{$\begin{array}{c}\text { Abrasion } \\
\text { Strength } \\
\left(\mathrm{cm}^{3} / 50 \mathrm{~cm}^{2}\right)\end{array}$} & \multirow{2}{*}{$\begin{array}{c}\text { Breaking Load } \\
\text { at the Dowel } \\
\text { Hole (MPa) }\end{array}$} \\
\hline & & $\mathbf{x}$ & $\mathbf{y}$ & $\mathbf{z}$ & & & & \\
\hline Arapey Black Basalt & U49 & n.d. & n.d. & n.d. & 3.0 & 3.4 & 5.1 & n.d. \\
\hline Maldonado Gray Granite & U2 & $19.3 \pm 1.7$ & $26.7 \pm 1.7$ & $15.2 \pm 0.7$ & 1.8 & 2.5 & 2.2 & $3.2 \pm 0.7$ \\
\hline Chamangá Gray Granite & U4 & $22.9 \pm 1.8$ & $20.6 \pm 1.3$ & $17.8 \pm 1.1$ & 2.3 & 2.5 & 2.4 & $2.9 \pm 0.6$ \\
\hline Cuchilla del Perdido Granite & U53 & $19.9 \pm 1.3$ & $21.7 \pm 0.6$ & $19.0 \pm 1.6$ & 2.5 & 2.6 & 1.9 & $3.2 \pm 0.3$ \\
\hline Moskart Granite & U7 & $9.1 \pm 3.7$ & $6.7 \pm 1.4$ & $9.1 \pm 1.2$ & 2.9 & 2.9 & 2.7 & $1.8 \pm 0.4$ \\
\hline Salmon Red Syenite & U15 & $14.7 \pm 2.5$ & $16.4 \pm 1.3$ & $15.7 \pm 1.0$ & 2.7 & 2.6 & 3.2 & $2.5 \pm 0.5$ \\
\hline Artigas Pearl Syenite & U46 & $9.2 \pm 1.7$ & $8.4 \pm 2.0$ & $4.4 \pm 1.4$ & 3.4 & 3.5 & 3.4 & $1.9 \pm 0.2$ \\
\hline Violeta Imperial Syenite & U47 & $8.4 \pm 0.7$ & $8.5 \pm 0.7$ & $13.0 \pm 1.0$ & 2.5 & 2.5 & 2.1 & $2.6 \pm 0.4$ \\
\hline
\end{tabular}




\section{Case Study: Slates}

Abstract

Slates are internationally known as roof and façade cladding material since prehistoric times. The methods required to mine and manufacture these dimensional stones are relatively simple in comparison to those utilized in granitic dimensional stones. This has led to a worldwide rentable commercialization of slate in the last centuries and also to the development of characteristic cultural landscapes.

In Uruguay several slates are mined and used in architecture, especially as façade cladding and floor slabs. The most important slates regarding their production and utilization are the dolomitic slates. These dolomitic slates are associated with the Neoproterozoic thrust and fold belt of the Dom Feliciano belt.

Representative samples have been geochemical and petrographical characterized, as well as petrophysical and petromechanical analyzed. The petrophysical and petromechanical properties were investigated in a very systematic way with respect to the new European standards, showing values comparable to those registered for internationally known slates.

Detailed structural and deposit analysis were carried in out Uruguay in order to evaluate the dolomitic slate deposits. The slates are linked to calc-silicate strata in a greenschist facies volcano-sedimentary sequence and the deposits are located in the limb of a regional fold, where bedding and cleavage are parallel. The main lithotype is a layered and fine-grained dolomitic slates with a quite diverse palette of colors: light and dark green, gray, dark gray, reddish and black. The mined slate is split into slabs $0.5-2 \mathrm{~cm}$ thick.

In the past, the average production in Uruguay was around 4,000 tons/year and a historical maximum of 13,000 tons was reached in 1993. The oscillations in the regional demand were the cause of several flourishing and decay cycles in the activity, but our investigation shows a considerable volume of indicated resources and therefore a very good potential. 


\subsection{Introduction}

Over the millennia slates in a broader sense have been one of the most favorite dimensional stones because of their particular attributes, such as fissility in a preferred direction and their high strength. Different shapes can be produced by simple technical means for roof and façade cladding (Fig. 4.1a), as well as for everyday objects and floor consolidation. Slate tablets and chalk (Fig. 4.1b) are one of the most important precursors to the personal computer, to which several generations owe their education in the acquisition of writing and mathematical skills.

Slate has been used as a roof cladding material since Neolithic times (Card, 2010). In regions where this resource was easily mined, the widespread application of slates in constructions resulted in the development of characteristic cultural landscapes. The traditional slate roof cladding has been displaced by other building materials since middle of the $20^{\text {th }}$ century, leading to a dramatic decline of the traditional slate industry.

Some rock types (e.g. sandstones, gneisses) also show fissility and are often sold as slates because they are used in similar applications (floor slabs, wall cladding, etc.). The term slate defines a fine-grained metamorphic rock that underwent low-grade regional metamorphism and possesses slaty cleavage (Allaby and Allaby, 1990; Jackson, 1997; Bucher and Frey, 2002). This cleavage is defined as a foliation, which results from the alignment of phyllosilicates in response to compressive tectonic deformation (Allaby and Allaby, 1990; Jackson, 1997; Bucher and Frey, 2002). With respect to the DIN EN 12326-1, a slate is a metamorphic rock with slaty cleavage formed by the alignment of phyllosilicate minerals (mainly mica and chlorite), quartz and other typical minerals. From the commercial point of view, a slate is a dimensional stone with a very well developed fissility, which allows the rock to be easily split. Afterwards the stone can be manufactured into roofing and cladding slate, or be used in special cases such as billiard table-tops, laboratory benches, and blackboards (Allaby and Allaby, 1990). 


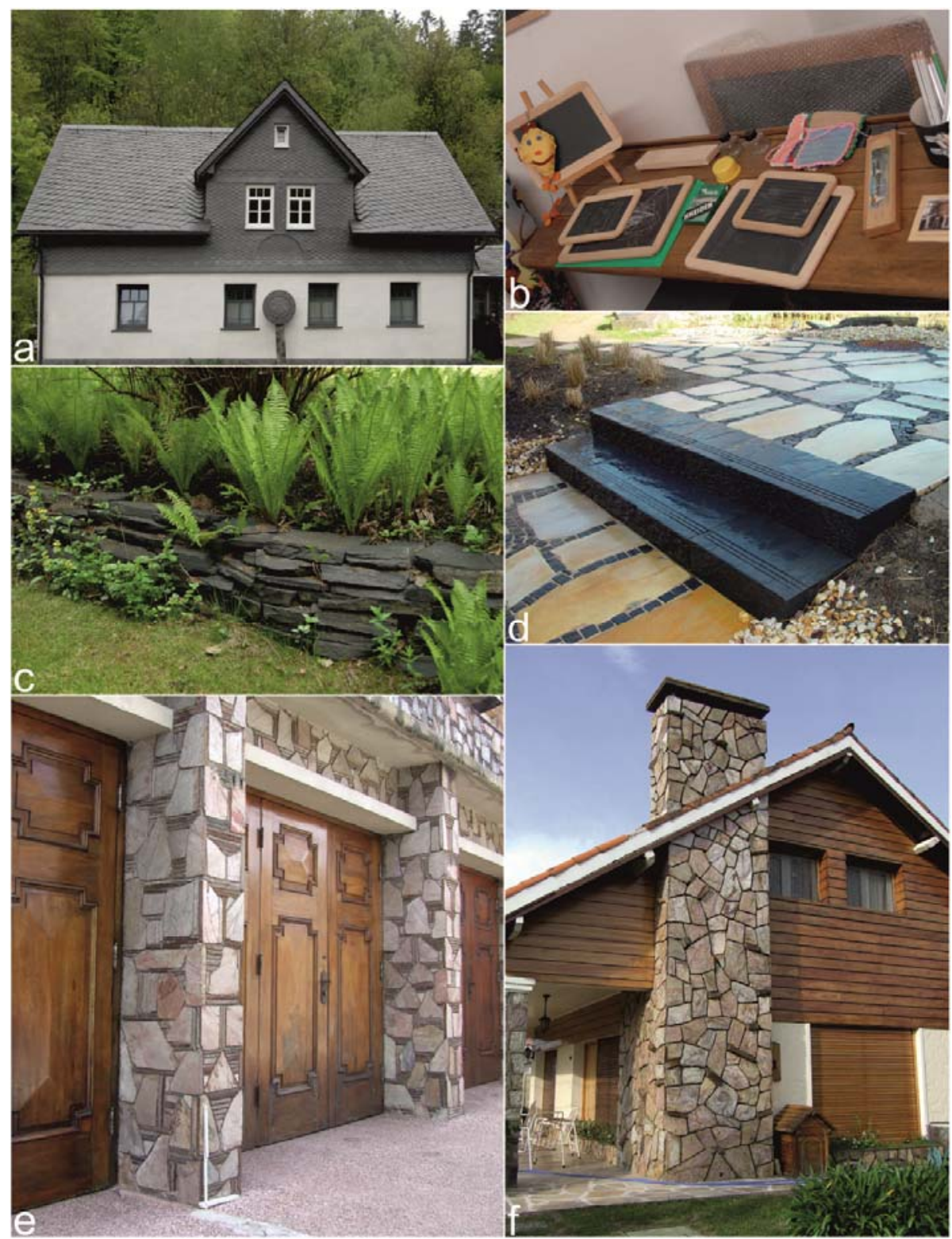

Fig. 4.1: Typical applications of slates in Uruguay and Germany: a. Roof and wall cladding in Germany using traditional black slate; $\boldsymbol{b}$. Slate tablets and blackboards for writing and drawing;

c. Dry stone wall of black slate used for a fern bed (Germany); d. Polygonal floor slabs of Brazil colored slate and stair trades of black slate (Germany); e. Uruguayan colored dolomitic slates used as wall cladding, note that the slabs are parallel and perpendicular to the slaty cleavage;

f. Uruguayan colored dolomitic slate applied as chimney cladding, socle cladding and polygonal floor slabs.

Rocks possessing this property are slates, some gneisses and phyllites, some limestones, quartzites and fine-grained pyroclastic rocks. In contrast, fine-grained sedimentary rocks with a high proportion of clay minerals are defined as shale. When they are split into thin slabs they are also commercialized as slates.

When the rock splits along the original bedding the terms used are "mass slate" or "parallel slate" (from the German term "Parallelschiefer"). When the dominant fissility 
is defined by a new developed cleavage, the term "transversal slate" (from the German "Transversalschiefer") is preferred. The angle between the slaty cleavage and the bedding can vary and is essentially the result of the tectonic overprinting.

Prior to the application of new varieties, it is necessary to analyze the stone petrographically and conduct petrophysical investigations to ensure a safe use for construction purposes. In the slate group it is critical to evaluate the amount of ore minerals (pyrite, chalcopyrite, etc.) and carbonates. Also petromechanical properties are of particular relevance, especially flexural strength, as well as water uptake, thermal behavior and freeze-thaw stability.

Another factor to be taken into account prior to the application of new slate varieties is the reliability of the supply. This is related to the fact that some slates are only available for a short time and only in a few specific formats. Relying on established commercial varieties will possibly prevent constructional and technical delivery problems.

In addition to the geology of the deposit, the durability of the slate plays a decisive role in their possible applications. The expected economic lifetime of roof and façade cladding slate depends on the resistance against environmental agents, especially weather conditions to which they are exposed. These include salt attack or freezethaw stability as well as impacts of thermal and hydric variations. Slates with inclusions, e.g. coarse-grained pyrite, are not very stable against temperature changes, due to the difference in thermal expansion among the rock components. This differential behavior can lead a loosening of these inclusions from slates used for different constructive purposes. Chemical and biological weathering can be critical for different types of slates, especially when considering the relevance of color stability.

In this study the Uruguayan slates are characterized in detail based on their petrography and petrophysical properties. In order to perform a comparison several slates from Spain, Brazil, Argentina, Portugal and Germany are also characterized 
from the petrographical and petrophysical point of view. Three groups of slates have been defined: dolomitic, semipelitic and pelitic slates.

\section{Overview of the slate market and slate applications}

According to Montani (2008), the main producers of slate in 2007 were, in order of importance, Spain, Brazil, China, Canada and India (Fig. 4.2); together these countries produce almost $75 \%$ of the world production. Other countries supplying slate as a dimensional stone are Italy, the USA, Germany, Belgium, Norway, France, Portugal and Turkey. The most important consumer is France. Traditional slate countries in terms of use are also Germany, Benelux and Great Britain.

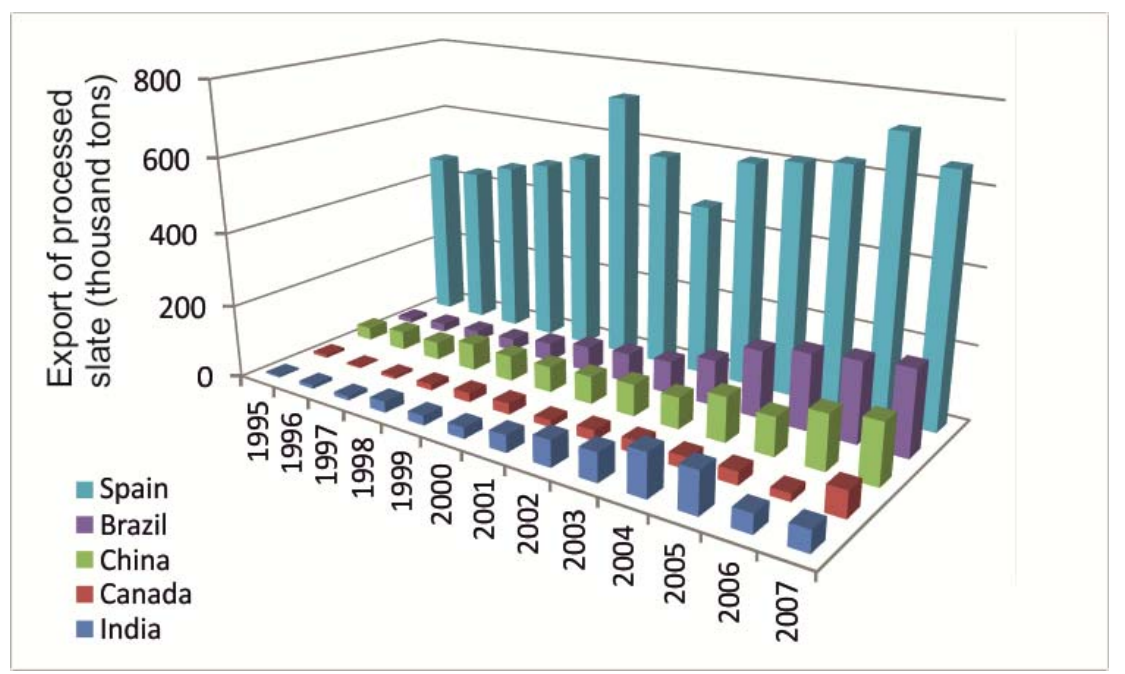

Fig. 4.2: Export of processed slate from the main producing countries between 1995 and 2007 (data after Montani, 2008).

A highly appreciated feature typical of slates is their uniform fabric and, in most of the cases, a deep black color. Their schistose structure is advantageous and convenient for mining and processing. Traditionally slates have been used as roof and façade cladding material. The optimization of modern mining techniques allows the excavation of larger blocks and better processing. This has led to a greater spectrum of products, and therefore, a wider application of slates.

For the design of outdoor areas the new application for slates include floor slabs (in various polygonal shapes), garden and landscaping elements (Fig. 4.1C), stone stair 
treads (Fig. 4.1d), gabions, stream and spring cladding, rubble stone and dry stone walls. Even gravestones and tombs are constructed using slate.

For indoor use several examples include pavements (in various polygonal shapes), wall cladding, window sills, marquetry elements for tables and furniture, as well as gift items (watches, platters, etc.). The spectrum of products also includes anti-bacterial washbasins and kitchen countertops with smooth, polished or rough surfaces. The use of slates for roof and façade cladding material has not lost its architectural importance. For this reason standards and quality criterions have been defined for roof and façade cladding slates in several economic regions (EU, USA, etc.). The quality criteria defined by these standars are matched by the traditional slate deposit (e.g. Mosel slate, Thüringer slate, Spanish slates, English slates), as well as by some of the new slate deposits (e.g. Chinese slates).

Traditional local use of fissile rocks in the areas of their exploitation is still common today, e.g. Gneiss in Switzerland and the "Alta Quartzite" in northern Norway. Since the middle of the $20^{\text {th }}$ century, slates from Uruguay have been utilized in the whole country for wall cladding and floor tiles (Fig. 4.1e and f).

\subsection{Geological setting of Uruguayan slates}

The Precambrian basement of Uruguay is represented, from west to east, by the Río de la Plata Craton (Almeida, 1971; Oyhantçabal et al, 2011), the Nico Pérez Terrane (Bossi and Ferrando, 2001; Oyhantçabal et al, 2011), the Dom Feliciano Belt (Fragoso-Cesar, 1980), the Punta del Este Terrane (Preciozzi et al, 1999) and the Rocha Group (Fig. 4.3). The Río de la Plata Craton (RPC) in Uruguay corresponds to the Piedra Alta Terrane, which includes metavulcanosedimentary belts and a central granitic-gneissic complex of Paleoproterozoic age (Bossi and Ferrando, 2001; Oyhantçabal et al, 2011).

The Nico Pérez Terrane (NPT), which was originally defined as part of the RPC (Bossi and Campal, 1992), was recently excluded from the craton by Oyhantçabal et al (2011) on the basis of differences in the tectono-stratigraphic evolution of both 
units. The NPT is bounded to the west by the RPC through the Sarandí del Yi Shear Zone (SYSZ) and to the east and southeast with the Dom Feliciano Belt (DFB) (Fig. 4.3).

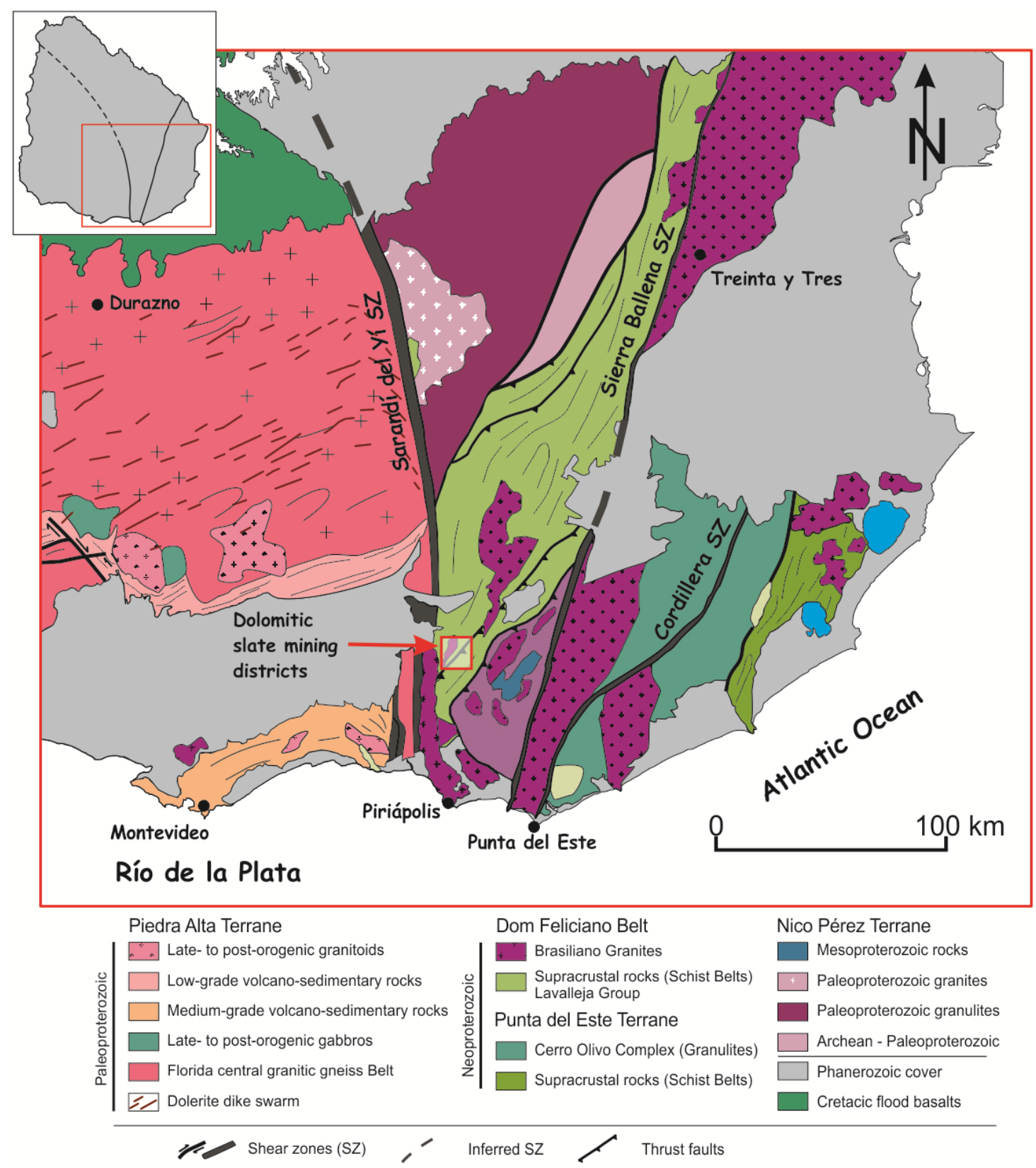

Fig. 4.3: Geological map of southeastern Uruguay. The location of the dolomitic slates mining district is indicated (redrawn after Oyhantçabal et al, 2010 and Sánchez Bettucci et al, 2010).

The DFB is the result of the collision of the Río de la Plata, Congo and Kalahari cratons that took place during the Late Neoproterozoic (Brasiliano Cycle) (Porada 1989). This collision led to the amalgamation of West Gondwana (Brito Neves and Cordani, 1991). The DFB comprises a granite, schist and foreland belt that extends 
from southernmost Uruguay to southern Brazil (Rio Grande do Sul and Santa Catarina states) (Basei et al, 2000). The Lavalleja Group (Bossi et al, 1965; Sánchez Bettucci 1998) represents the schist belt in Uruguay (Basei et al, 2008).

Especially relevant for the present work is the Lavalleja Group (LG), since here are located the dolomitic slate deposits. This unit was first defined by Bossi et al (1965), being further studied by Midot (1984), Sánchez Bettucci (1998), Sánchez Bettucci and Ramos (1999) and Oyhantçabal et al (2001). All these authors agree that the LG is composed of metavolcanic and metasedimentary sequences that underwent metamorphism under greenschist to lower amphibolite facies conditions. This group crops out to the north of Pan de Azúcar city to $70 \mathrm{~km}$ northwest of Treinta y Tres city, and between SYSZ and Sierra de Ánimas Complex (to the west) and Carapé Complex (to the east) (Fig. 4.3).

In the southern region the LG was further subdivided by Midot (1984), Sánchez Bettucci (1998) and Oyhantçabal et al (2001). The first author defines the Minas and Fuente del Puma Series, while the second author, recategorized these units as formations and added a third one: the Zanja del Tigre Formation. Oyhantçabal et al (2001) proposed a different approach, subdividing the LG into four lithological associations. These associations are, from west to east: La Plata (LPA), Peña Blanca (PBA), Minas Viejas (MVA) and Zanja del Tigre-Cuchilla Alvariza (ZTCAA).

The lithologies of the current investigation belong to the Fuente del Puma Formation (Midot 1984, Sánchez Bettucci 1998) or to the lithological association Minas Viejas (Oyhantçabal et al, 2001). The preferred classification used in this study is the one defined by Oyhantçabal et al (2001), since it presents a more detailed analysis in the considered area. The MVA is where the dolomitic slate deposits are exposed. The northwestern boundary of this association with the PBA is the Peña Blanca Lineament, which also acts as a boundary with the LPA to the south. The Mina Oriental Lineament is the boundary of the MVA with the ZTCAA (to the east) and with the Carapé Granitic-Gneissic Complex, the syn-tectonic Brasiliano granites and a pre-Brasiliano basement (to the north). 
The MVA, as originally defined, is composed of calcareous phyllites, basic metavolcanics, limestones, and metapelites. Geomorphologically, this association forms NNE elongated hills in the south central region, with very steep slopes and associated $V$-shaped valleys. While in the north the hills show less pronounced slopes and the valleys are narrow and flat bottom-shaped (Oyhantçabal et al, 2001). These authors considered that the calcareous phyllites are the predominant lithological type. They form outcrops of elongated ridges kilometers in scale and always in the upper topographic positions. An excellent layering defines these exposures, determined by alternating carbonate and phyllosilicate layers and a welldeveloped cleavage.

These structural features correspond to a regional transpressional tectonic regime and are defined by strike-slip faults, thrust faults and megafolds observable in aerial and satellite images. Further details to the structural features observed in the studied lithologies are described in the deposit characterization subchapter.

\subsection{Lithological inventory}

The main slate quarries active in Uruguay today were sampled for geochemical and petrographic analysis. In order to identify the factors leading to a commercially viable stone, other locations were sampled where mining was unsuccessful. Several internationally known slates were also analyzed as a reference for comparison (e.g. the Spanish roofing slates). All the rocks investigated are listed in Table 4.1 with their corresponding lithology, location and sample abreviation.

\subsubsection{Geochemistry}

The geochemistry of the slates was determined by X-Ray fluorescence (XRF). The results are given in Table A.4.1 and A.4.2 (appendix). The major components of the slates are $\mathrm{SiO}_{2}, \mathrm{Al}_{2} \mathrm{O}_{3}, \mathrm{Fe}_{2} \mathrm{O}_{3}, \mathrm{MgO}, \mathrm{CaO}, \mathrm{Na}_{2} \mathrm{O}, \mathrm{K}_{2} \mathrm{O}$ and $\mathrm{CO}_{2}$.

The $\mathrm{SiO}_{2}$ content varies from $29.15 \mathrm{wt} \%$ in the red-green variety (UY-21) to $66.9 \mathrm{wt} \%$ in Vila Nova de Foz Côa (PO). The Uruguayan varieties that show higher contents of 
$\mathrm{SiO}_{2}$ are Piedra laja rosada con gris (UY-106) and Piedra laja Puntas del Chafalote (UY-108), with 56.27 and 60.92 wt\%, respectively.

$\mathrm{Al}_{2} \mathrm{O}_{3}$ shows a similar distribution, although is present in a lower proportion: between 6.07 wt\% in Piedra laja verde oscura (U38C) and 24.49 wt\% in Ardósia de Canelas $(\mathrm{PL})$. The proportion of $\mathrm{Al}_{2} \mathrm{O}_{3}$ is higher for the Uruguayan varieties $\mathrm{UY}-106$ and $\mathrm{UY}$ 108 than the other 15 Uruguayan samples. The highest $\mathrm{Al}_{2} \mathrm{O}_{3}$ values were analyzed for the samples of other countries (e.g. Argentina, Spain; Table A.4.1).

Table 4.1: List of investigated slates.

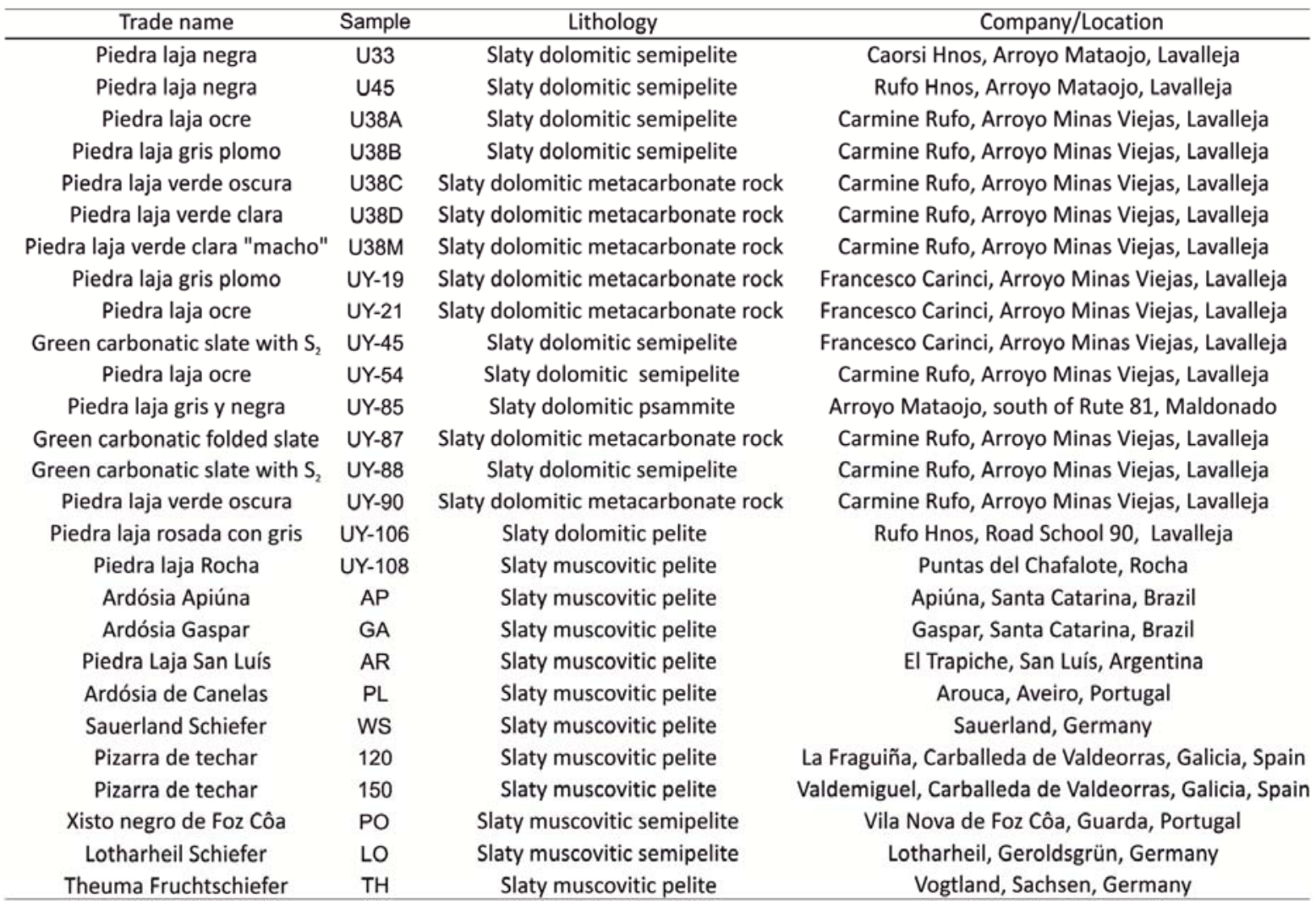

The $\mathrm{Fe}_{2} \mathrm{O}_{3 \mathrm{t}}$ content shows a similar trend, varying from $1.90 \mathrm{wt} \%$ in Piedra laja verde clara (U38D) to $10.21 \mathrm{wt} \%$ in Ardósia de Canelas (PL). In the Uruguayan varieties the higher values of $\mathrm{Fe}_{2} \mathrm{O}_{3 \mathrm{t}}$ are found in UY-106 and UY-108, with 6.52 and 4.78 wt\%, respectively. Note that all the Fe present is shown as $\mathrm{Fe}_{2} \mathrm{O}_{3 \mathrm{t}}$, not discriminated from $\mathrm{FeO}$.

The $\mathrm{MgO}, \mathrm{CaO}$ and $\mathrm{CO}_{2}$ contents show a clear relationship, so that the samples with higher contents of $\mathrm{MgO}$ and $\mathrm{CaO}$ also show the higher content of $\mathrm{CO}_{2}$. This is due to 
the fact that these three oxides combine with $\mathrm{CO}_{2}$ to form carbonates. Ardósia Gaspar (GA) shows the lowest $\mathrm{CO}_{2}$ content. The highest contents of $\mathrm{MgO}$ are observed in the variety Piedra laja gris plomo (UY-19) with $12.84 \mathrm{wt} \%$, and in general, for all Uruguayan slates analyzed with the exception of UY-108.

Another negative correlation is observed between the carbonate forming oxides and $\mathrm{SiO}_{2}$ as well as $\mathrm{Al}_{2} \mathrm{O}_{3}$. $\mathrm{Na}_{2} \mathrm{O}$ varies from less than $0.01 \mathrm{wt} \%$ in almost all Uruguayan slates to $2.52 \mathrm{wt} \%$ in Xisto negro de Foz Côa (PO). $\mathrm{K}_{2} \mathrm{O}$ values range from $1.83 \mathrm{wt} \%$ in Piedra laja verde clara y oscura "macho" (UY-19) to 4.64 wt\% in UY-108.

\subsubsection{Organic carbon}

Knowing the organic carbon content is essential when relating it with some of the rock properties, such as the color and the antibacterial properties. The total carbon $\left(\mathrm{C}_{\mathrm{tot}}\right)$ in the analyzed slates varies from $0.00 \mathrm{wt} \%$ in the Theuma Fruchtschiefer (TH) (Fischer et al, 2011) to 7.34 wt\% in the Piedra laja verde clara (U38D) (Table 2). Dolomitic slates show a higher proportion of $\mathrm{C}_{\text {tot }}$ in all the samples analyzed, with the proportion varying between $3.40 \mathrm{wt} \%$ in Piedra laja negra Rufo Hnos (U45) and 7.34 wt\% in the already mentioned U38D. The pelitic and semipelitic slates contain $\mathrm{C}_{\text {tot }}$ values up to $0.87 \mathrm{wt} \%$, as in the case of Ardósia Apiúna (AP).

Considering how much of the carbon present is actually organic carbon is important because of the antimicrobial properties of the organic compounds, especially of the sulfonated shale oils (Listemann et al, 1993; Fluhr et al, 1998; Gayko et al, 2000). Organic carbon $\left(\mathrm{C}_{\mathrm{org}}\right)$ contents are very low in all the samples analyzed; between $0.00 \mathrm{wt} \%$ in TH (Fischer et al, 2011) and $0.51 \mathrm{wt} \%$ in the Sauerland Schiefer (WS). The $\mathrm{C}_{\text {org }}$ content in the dolomitic slates ranges from 0.10 to $0.18 \mathrm{wt} \%$ and represents between 1.6 and $3.8 \%$ of the $C_{\text {tot }}$ present.

Pelitic and semipelitic slates show a $\mathrm{C}_{\text {org }}$ content between 0.11 and $0.51 \mathrm{wt} \%$ of the whole sample, being markedly higher for some samples in comparison to the dolomitic slate group. The proportion of $\mathrm{C}_{\text {org }}$ in the $\mathrm{C}_{\text {tot }}$ is very high and ranges between 18.8 and $95.5 \mathrm{wt} \%$ in the pelitic and semipelitic slates (Table 4.2). 
Table 4.2: Total carbon $\left(\mathrm{C}_{\text {tot }}\right)$, total organic carbon $\left(\mathrm{C}_{\text {org }}\right)$, total carbonatic carbon $\left(\mathrm{C}_{\text {carb }}\right)$, total nitrogen $\left(\mathrm{N}_{\mathrm{tot}}\right)$ and total sulfur $\left(\mathrm{S}_{\text {tot }}\right){ }^{*}$ : data after Fischer et al, 2011).

\begin{tabular}{ccccccccc}
\hline Sample & $\mathrm{C}_{\text {tot }}$ & $\mathrm{C}_{\text {org }}$ & $\mathrm{C}_{\text {carb }}$ & $\mathrm{CaCO}_{3}$ & $\mathrm{~N}_{\text {tot }}$ & $\mathrm{S}_{\text {tot }}$ & $\mathrm{C}_{\text {org }} / \mathrm{N}$ & $\mathrm{C}_{\text {org }} / \mathrm{S}$ \\
\hline U33 & 4.66 & 0.18 & 4.48 & 37.3 & 0.020 & 0.116 & 9.0 & 1.6 \\
U45 & 3.40 & 0.12 & 3.28 & 27.3 & 0.017 & 0.022 & 7.1 & 5.5 \\
U38A & 6.18 & 0.10 & 6.08 & 50.7 & 0.011 & 0.003 & 9.1 & 33.3 \\
U38B & 4.99 & 0.11 & 4.88 & 40.7 & 0.012 & 0.002 & 9.2 & 55.0 \\
U38C & 7.29 & 0.12 & 7.17 & 59.7 & 0.013 & 0.003 & 9.2 & 40.0 \\
U38D & 7.34 & 0.12 & 7.22 & 60.2 & 0.013 & 0.022 & 9.2 & 5.5 \\
U38M & 6.97 & 0.11 & 6.86 & 57.2 & 0.013 & 0.098 & 8.5 & 1.1 \\
AP & 0.87 & 0.16 & 0.71 & 5.9 & 0.034 & 0.006 & 4.7 & 26.7 \\
GA & 0.14 & 0.13 & 0.01 & 0.1 & 0.042 & 0.006 & 3.1 & 21.7 \\
AR & 0.12 & 0.11 & 0.01 & 0.1 & 0.019 & 0.070 & 5.8 & 1.6 \\
PL & 0.40 & 0.39 & 0.01 & 0.1 & 0.079 & 0.233 & 4.9 & 1.7 \\
WS & 0.74 & 0.51 & 0.23 & 1.9 & 0.083 & 0.300 & 6.1 & 1.7 \\
120 & 0.41 & 0.38 & 0.03 & 0.2 & 0.053 & 0.070 & 7.2 & 5.4 \\
150 & 0.44 & 0.42 & 0.02 & 0.2 & 0.057 & 0.076 & 7.4 & 5.5 \\
PO & 0.21 & 0.20 & 0.01 & 0.1 & 0.035 & 0.111 & 5.7 & 1.8 \\
LO & 0.80 & 0.15 & 0.65 & 5.4 & 0.032 & 0.043 & 4.7 & 3.5 \\
TH & $0.00^{*}$ & $0.00^{*} 0.00^{*}$ & $0.0^{*}$ & n.d. & $0.0^{*}$ & n.d. & $0.0^{*}$ \\
\hline
\end{tabular}

\subsubsection{Petrography}

The petrography of the investigated slates show a wide variation (in mineralogy, fabric, etc), especially when comparing the dolomitic slates to the pelitic and semipelitic slates. The main difference is the occurrence of carbonate minerals, which are present in very high proportions in the first group, and are practically absent in the other two groups.

Determining mineral compositions in fine-grained metasedimentary rocks is often difficult by conventional optical microscopy, and thus alternative approaches were applied. The software Slatenorm (Prof. Dr. Dieter Jung, p. c.) and the X-ray diffraction Rietveld method were used to quantify the mineralogical composition (Tables 4.3 and A.4.3).

The first method calculates the normative minerals using the geochemistry, while the second performs a quantitative phase analysis using the XRD results. A strong correlation exists between both methods on the amounts of quartz. However, in the case of the phyllosilicates the correlation is not so obvious because of the uncertainty concerning the composition of these minerals (Ward and Gómez Fernández, 2003). In the dolomitic slates, the values for these phyllosilicates obtained by both methods 
are similar when illite coexists with muscovite. However, for the rest of the slates studied such a simple correlation does not exist; the chlorite contents are higher using the Rietveld method. Dolomite contents are similar when using both methods.

Table 4.3: X-ray diffraction result for the Uruguayan dolomitic slates.

\begin{tabular}{|c|c|c|c|c|c|c|c|c|c|c|}
\hline Sample & Dolomite & Calcit & Quartz & Albite & Muscovite & Illite & Chlorite & Pyrite & Rutile & Hematite \\
\hline U33 & 36.5 & 0.9 & 28.4 & & 11.4 & 15.6 & 6.7 & & 0.5 & \\
\hline U45 & 24.5 & & 32.9 & 8.4 & 24.6 & & 9.6 & & & \\
\hline U38A & 49.2 & & 26.6 & & 11.2 & 11.0 & 2.1 & & & \\
\hline U38B & 40.3 & & 29.9 & & 13.4 & 12.1 & 3.2 & 0.2 & 0.3 & 0.6 \\
\hline U38C & 55.8 & & 21.9 & & 13.7 & 2.4 & 6.0 & & 0.3 & \\
\hline U38D & 58.5 & & 21.8 & & 10.4 & 5.9 & 3.3 & 0.2 & & \\
\hline U38M & 55.8 & & 22.9 & & 7.1 & 9.4 & 4.6 & 0.3 & & \\
\hline
\end{tabular}

The normative mineralogical composition obtained has been used to classify the slates with respect to the nomenclature of the British Geological Survey (Robertson, 1999). Following this classification schema, three different categories are used based on the quartz, feldspar, phyllosilicate and carbonate mineral contents.

The first category is for rocks containing mostly quartz, feldspar and mica. A second category is for rocks that have between 10 and $50 \%$ carbonate and/or calc-silicate minerals and at least $50 \%$ quartz + feldspar + mica. A third category uses another ternary diagram for the classification of rocks containing more than $50 \%$ calc-silicate and/or carbonate minerals (see Fig. 4.4). Textural and mineralogical qualifiers (e.g. slaty, dolomitic) are used to present more information on the classification of these rocks (see Robertson, 1999). For all the rocks studied, the qualifier "slaty" will be used because all of them show a slaty cleavage that determines their strong fissility.

Uruguay has a relatively large variety of slates, which are incorrectly described as quartzites (Comunità Economica Europea-Uruguay, no date) or chloritic phyllites (Coronel et al, 1987). Most of the Uruguayan rocks analyzed contain dolomite as the main carbonate mineral, and the qualifier "dolomitic" is used instead of the word "calcareous". 


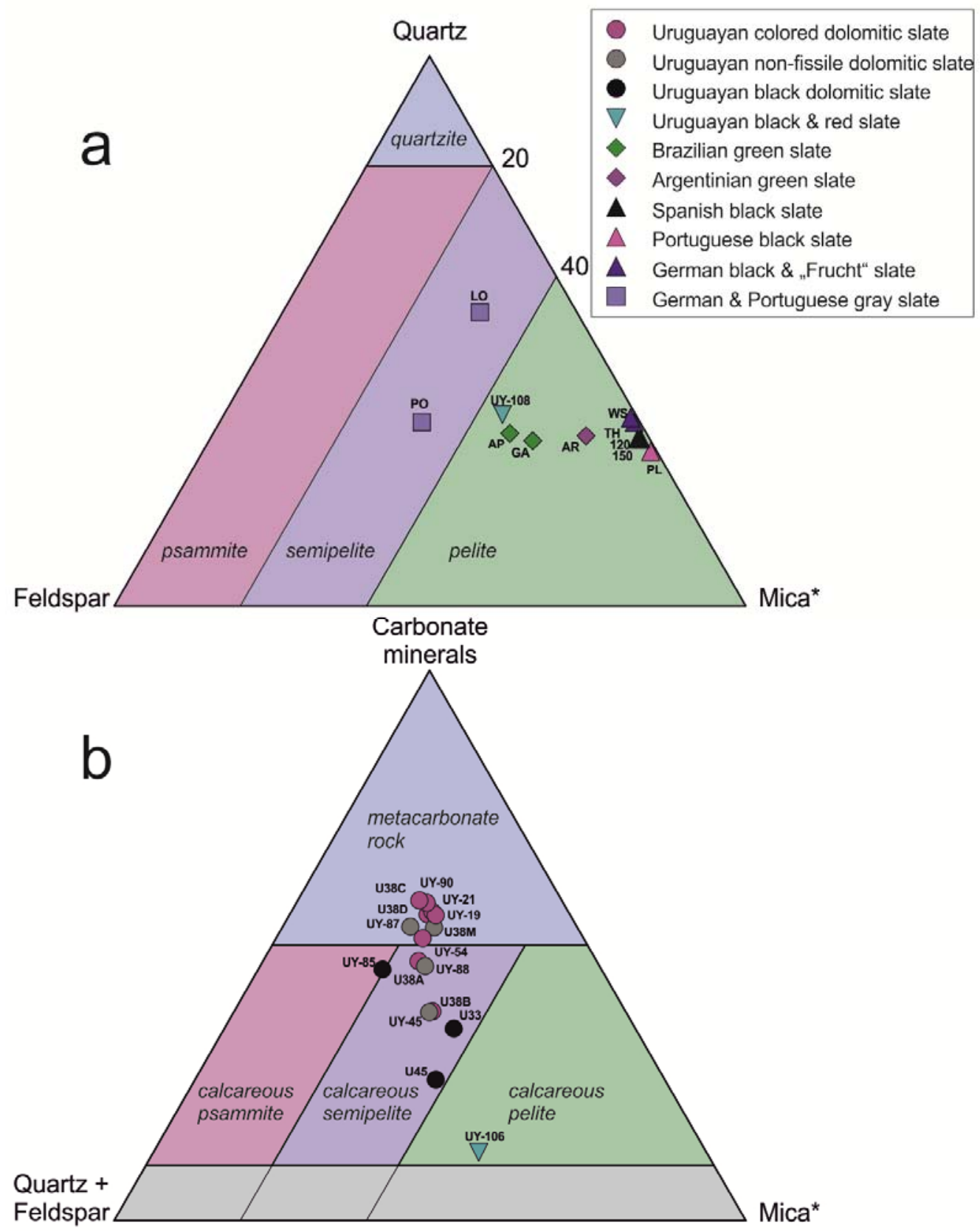

Fig. 4.4: Classification of the investigated slates based on the normative composition of their sedimentary protolith (after Robertson 1999). a. Pelitic and semipelitic slates and b. dolomitic slates (mica*: includes all the minerals not considered in the other vertices).

The investigated slates (Table 4.1) were classified into five subgroups using the schema of Robertson (1999) and their normative mineralogy (Table A.4.3 in appendix and Fig. 4.4). These groups are: i) Slaty semipelites, e.g. Xisto negro de Foz Côa (PO) and Lotharheil Schiefer (LO) (Fig. 4.4a); ii) Slaty pelites, includes the majority of the investigated rocks, as well as the Piedra laja Puntas del Chafalote (UY-108) (Fig. $4.4 a)$; iii) Slaty dolomitic metacarbonate rocks, comprising the following commercial varieties: Piedra laja verde oscura (U38C), Piedra laja verde clara (U38D) and Piedra 
laja verde clara "macho" (U38M) (Fig.5.4b); iv) Slaty dolomitic semipelites, e.g. Piedra laja ocre (U38A), Piedra laja negra Caorsi Hnos (U33) and Piedra laja gris y negra (UY-85) (Fig. 4.4b). Note that the last variety occurs at the border between the calcareous semipelites and calcareous psammite, due to its higher content of quartz and feldspar, and finally $v$ ) the slaty dolomitic pelites, composed of only one variety: Piedra laja rosada con gris (UY-106) (Fig. 4.4b).

For simplicity the five subgroups mentioned above will be categorized into three main groups. Dolomitic slates are those rocks that classify as slaty dolomitic metacarbonate rocks, slaty dolomitic semipelite or slaty dolomitic pelite; as pelitic slates, rocks that group as slaty pelites; and as semipelitic slates are those designated as slaty semipelite.

\subsubsection{Dolomitic slates}

The dolomitic slates are composed mainly of dolomite, quartz and phyllosilicates (muscovite, illite and chlorite) (Table A.4.3, Fig. 4.4b and 4.5). The normative amount of dolomite varies between 11.86 wt\% in the Piedra laja rosada y gris (UY-106) and $57.92 \mathrm{wt} \%$ in the Piedra laja verde clara (UY-90). The grain size ranges from 0.04 to $0.18 \mathrm{~mm}$. Grains are generally anhedral and very difficult to discern as individual grains (Fig. 4.5). The black slates show a lower normative dolomite content, between 23.39 and $32.97 \mathrm{wt} \%$. Calcite is present in a low normative proportion, ranging from zero to $4.12 \mathrm{wt} \%$, and normative siderite is present in only two samples at very small amounts, between 0.08 and 0.16 wt\%.

Quartz is the second most important mineral, as its normative abundance comprises between 19.64 wt\% in the Piedra laja ocre (U38A) and 36.01 wt\% in the Piedra laja rosada con gris (UY-106). It occurs as anhedral grains with sizes that generally range from 0.05 to $0.12 \mathrm{~mm}$. In the black slates grain sizes can reach up to $0.30 \mathrm{~mm}$, and sometimes up to $1.10 \mathrm{~mm}$ as in some psammitic layers of the Piedra laja negra Caorsi Hnos (U33) (Fig. 4.5a). The quartz grains are normally elongated parallel to the foliation with an aspect ratio between 1.5 and 4 . In the black variety of Rufo Hnos (U45) thin layers of about one centimeter, containing up to $50 \%$ medium-grained 
$(0.30 \mathrm{~mm})$ quartz grains, have been recognized (Fig. 4.5b). Quartz sometimes appears recrystallized or with undulose extinction.

Phyllosilicates form the third most important mineral component in these rocks. In thin section determining which phyllosilicate is present is difficult due to the very fine grain size. The most recognizable is muscovite. This mineral is one of the main normative phyllosilicates calculated using the program Slatenorm, as it comprises between $14.59 \mathrm{wt} \%$ in the Piedra laja negra con gris (UY-85) and $31.82 \mathrm{wt} \%$ in the Piedra laja rosada con gris (UY-106).

However, in the majority of the dolomitic slates, the normative muscovite content is not higher than $24.07 \mathrm{wt} \%$ (Piedra laja negra, Caorsi Hnos). Muscovite appears as subhedral crystals of around 30 to $150 \mu \mathrm{m}$ in size with an aspect ratio of 4 to 12 . Normative paragonite, a sodium-rich mica, is only present in the Piedra laja negra Rufo Hnos and when these two micas coexist, they represent $24.41 \mathrm{wt} \%$ of the rock. Therefore, the black dolomitic slates contain the greater proportion of mica minerals. Only some of the dolomitic slates studied show normative chlorite. This mineral has been recognized in hand specimens due to its typical green color, as well as in thin sections (e.g. U38A, Fig. 4.5c) and in x-ray diffraction (Table 4.3). The phyllosilicates occur parallel to the $S_{0-1}$ foliation and in some varieties also along a second foliation $\mathrm{S}_{2}$ (Fig. $4 \mathrm{~d}$ ) or to folds developed in a later deformation phase (Fig. 4.5h).

In the calculations using Slatenorm (Table A.4.3), the normative chlorite mineral is defined as daphnite (Fe-Al-chlorite) and the serpentine group consisting of the minerals serpentine (Mg-serpentine), amesite (Mg-Al-serpentine) and greenalite (Feserpentine). The serpentine group minerals were not identified in thin section and are not present in the $\mathrm{x}$-ray diffractograms, being only present as normative minerals. 


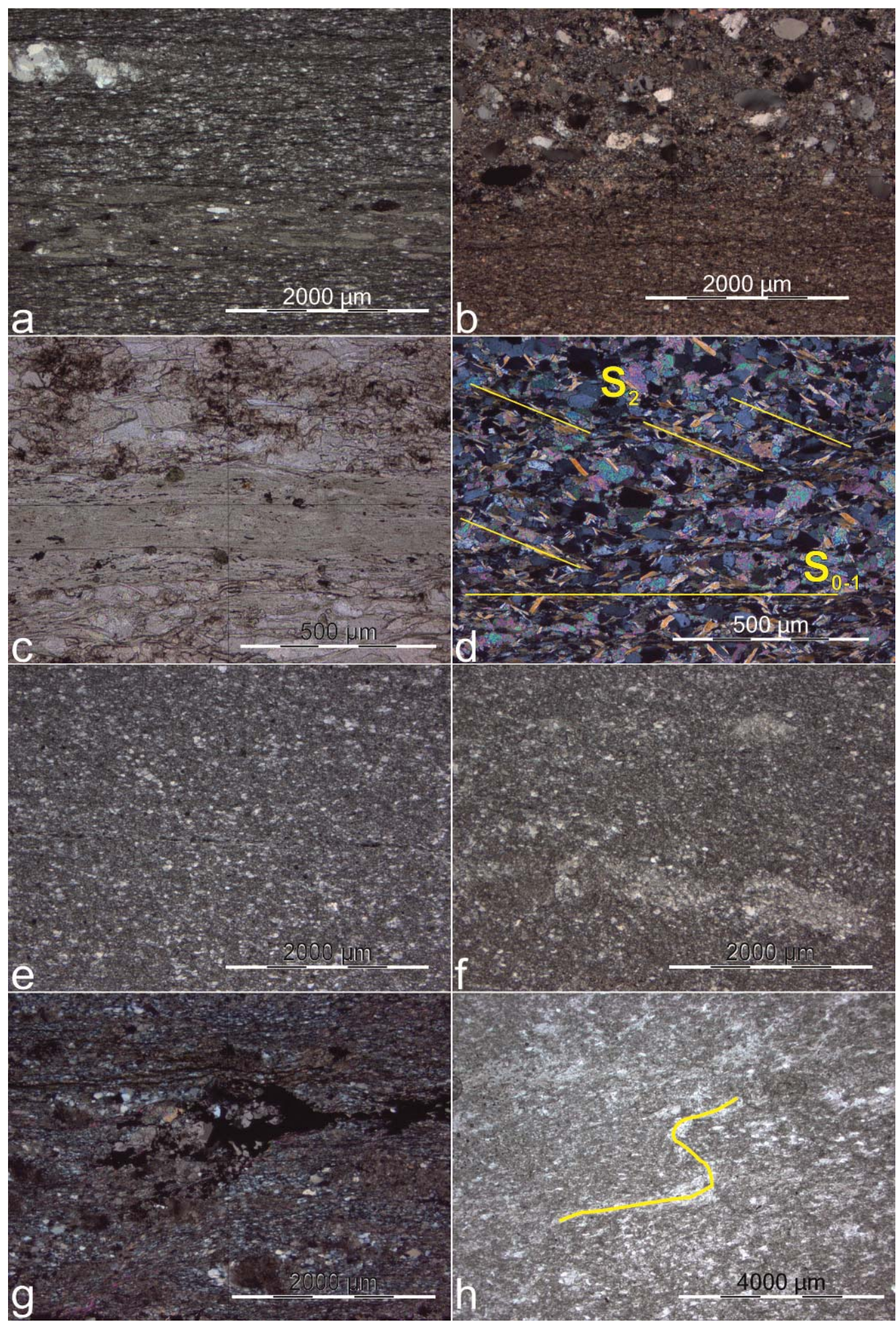

Fig. 4.5: Thin section images of the investigated samples. The slaty foliation is parallel to the image length. a. Black dolomitic-slate (U33) in cross polarized light (CPL) with a large quartz clast visible

in the upper left corner; b. Piedra laja negra Rufo Hnos (U45) in CPL containing a distinct psammitic layer; c. Piedra laja ocre (U38A) in plane polarized light (PPL), the phyllosilicatic layer in the center shows a light green colouration due to chlorite. Note the iron hydroxide staining above;

d. Piedra laja gris plomo (U38B) in CPL. $\mathrm{S}_{0-1}$ and a $\mathrm{S}_{2}$ are indicated by the phyllosillicates; e. Piedra laja verde oscura (U38C) in PPL showing a poor development of phyllosilicatic layers; $\mathbf{f}$. Piedra laja verde clara (U38D) in PPL, phyllosilicate layers are missing; g. Piedra laja verde clara "macho" (U38M) in PPL. Relatively coarse dolomite, quartz and opaque grains are visible; $\mathbf{h}$. Sample UY-87 in PPL is a green dolomitic slate which shows a folded $S_{0-1}$. 
There is an inverse correlation between the normative amount of dolomite on the one side and the normative content of quartz + feldspar and mica on the other. The Piedra laja verde oscura (U38C) and verde clara (U38D) have the highest normative dolomite content of the commercial varieties analyzed and the lowest proportion of normative quartz and muscovite (Table A.4.3, Fig. 4.4b). On the other hand, the Piedra laja rosada con gris (UY-106) shows the highest quartz and muscovite normative proportions and the lowest dolomite normative content.

Accessory minerals determined are feldspar, apatite, tourmaline, zircon and opaques (magnetite and pyrite). In the black Rufo Hnos (U45) variety, psammitic layers containing anhedral grains of plagioclase are recognizable with sizes similar to those of the quartz grains $(30 \mu \mathrm{m})$. The reddish colored varieties (U38A to U38M) show patches red and orange in color (possibly iron hydroxides, Fig. 4.5c).

The black slates have lower proportions of normative dolomite when compared to the colored slates and show, in turn, higher proportions of normative quartz and phyllosilicates (muscovite, chlorite and illite). This relationship between the mineralogical composition and the color is confirmed by the variety Piedra laja gris plomo (U38B), which is the darkest slate of the northern district (AMVD) and shows the lowest proportions of dolomite in the entire mining district.

\subsubsection{Pelitic slates}

The pelitic slates are the most heterogeneous of the rocks investigated (Table A.4.3, Fig. 4.4 and 4.6). These rocks have a high proportion of normative phyllosilicates (between 38 and 68\%), mainly muscovite, but also chlorite, chloritoid and minor biotite (in Ardósia Apiúna, AP). The other main constituents are quartz and feldspar.

Muscovite appears as euhedral crystals with sizes ranging between 50 and $100 \mu \mathrm{m}$. They have an aspect ratio of 20 and are oriented parallel to the foliation. In the psammitic layers of sample AP, muscovite grains show sizes up to $250 \mu \mathrm{m}$ with an aspect ratio up to 16. Chlorite is the dominant phyllosilicate in the Piedra laja San Luís (AR). Chlorite is observable in the varieties Pizarra de techar La Fraguiña 
(sample 120) and Valdemiguel (sample 150), where they appear as mica fishes ranging from 60 to $100 \mu \mathrm{m}$ in size with an aspect ratio up to two (Fig. 4.6f). This observation has also been reported by Ruiz García (1977) and García-Guinea et al (1998).

Chloritoid is present in the Ardósia de Canelas (PL) as euhedral crystals with a size range of 50 to $100 \mu \mathrm{m}$ and an aspect ratio of 10 . Their long axes are parallel, transverse or perpendicular to the foliation (Fig. 4.6h).

Another important constituent is quartz with a smaller variation of its proportion, the normative content ranges between 28 and $34 \mathrm{wt} \%$. This mineral forms anhedral grains with sizes ranging between 40 to $80 \mu \mathrm{m}$, and up to $300 \mu \mathrm{m}$ in size in the Ardósia de Canelas (PL) or $600 \mu \mathrm{m}$ in the psammitic layers of the Ardósia Apiúna (AP) (Fig. 4.6a). Commonly, in the more phyllosilicate-rich slates the grains are elongated parallel to the foliation with an aspect ratio up to six (e.g.: Pizarra de techar La Fraguiña) (Fig. 4.6e and f). In the other varieties, those with lower phyllosilicate contents, the grains are very well rounded. Undulose extinction was not observed.

The other main constituent is feldspar, whose normative amount varies between 0 to $20.3 \mathrm{wt} \%$. Due to the very fine grain size, determination with the petrographic microscope was not possible, with the exception of the feldspars in the psammitic layers of the Ardósia Apiúna (AP). The accessory minerals consist of rutile, apatite, magnetite and pyrite. In the Sauerland Schiefer (WS) carbonate is also observable as an accessory mineral.

Varieties with a higher content of normative phyllosilicates (and lower feldspar) are Arouca (PL), La Fraguiña (sample 120), Valdemiguel (sample 150), Theuma Fruchtschiefer (TH) and Sauerland (WS). The high amount of $\mathrm{C}_{\text {org }}$ in the form of graphite ranges between 0.39 to $0.53 \mathrm{wt} \%$ (Table 4.2), and is responsible for their characteristic black or dark gray color. An exception to this characteristic is sample $\mathrm{TH}$, which shows no presence of $\mathrm{C}_{\text {org }}$ and whose dark gray color is dotted by millimeter sized chlorite pseudomorphs after cordierite (Fischer et al, 2011). 


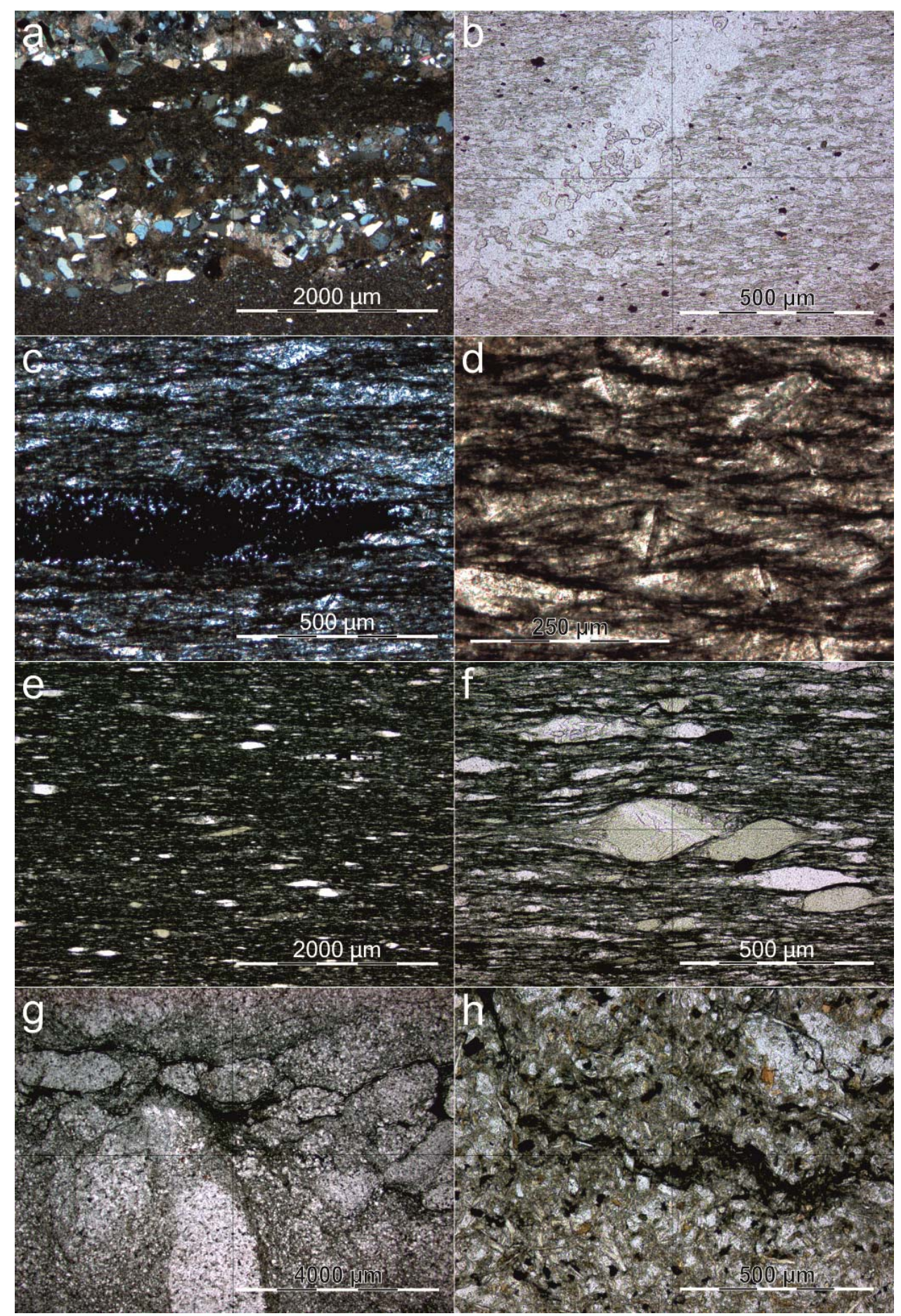

Fig. 4.6: Thin section images of the investigated slates. The slaty foliation is parallel to the image length. a. Ardósia Apiúna (AP) in CPL with quartz grains showing undulatory extinction in the psammitic layers; $\boldsymbol{b}$. Piedra laja San Luís (AR) in PPL. Quartz vein crosscuts the foliation as determined by the alignment of chlorite; $\mathbf{c}$. Ardósia de Canelas (PL) in CPL. Quartz microlithons between phyllosilicatic layers and a lens of tiny pyrite porphyroblasts; $\boldsymbol{d}$. Ardósia de Canelas (PL) in PPL. Note the chloritoid porphyroblast surrounded by or transversal to the foliation; e. Pizarra de techar La Fraguiña (120) in CPL with a very well-developed foliation. Quartz and chloritoid grains are elongated parallel to the foliation; $f$. Detail of the texture in the Pizarra de techar La Fraguiña (120) in PPL. Note the chlorite "fish" in the center with a light green color and the white quartz grains; g. Xisto negro de Foz Côa (PO) in PPL with opaques and a phyllosilicate-rich, irregular solution transfer foliation. Note the lighter and darker domains, the latter with a relatively higher proportion of phyllosilicates and a finer grain size; $\mathbf{h}$. Detail of the solution transfer foliation.in the Xisto negro de Foz Côa (PO) in PPL. 
Slaty pelites with lower amounts of normative phyllosilicates are, in decreasing order: Piedra laja San Luís (AR), Ardósia Gaspar (GA), Ardósia Apiúna (AP) and Piedra laja Puntas del Chafalote (UY-108). Higher proportions of normative serpentine minerals occur with respect to the other phyllosilicates. These rocks show green colors, due to the relatively high proportion of modal chlorite.

\subsubsection{Semipelitic slates}

Semipelitic slates are rocks with even lower normative phyllosilicate contents (Fig. 4.6). Their main constituent is quartz, whose normative abundance ranges between 33 and $50 \mathrm{wt} \%$, and occurs as anhedral rounded grains of up to $120 \mu \mathrm{m}$. In the Xisto negro de Foz Coa (PO) two families of grain sizes can be differentiated, the smaller group ranges 40-50 $\mu \mathrm{m}$ and the larger 80-100 $\mu \mathrm{m}$ (Fig. 4.6g).

Feldspar, with 14 to 34 wt\% normative abundance, is mainly represented by plagioclase grains showing a similar grain size to quartz (40 and $100 \mu \mathrm{m})$. The normative phyllosilicates comprise 28 to $30 \mathrm{wt} \%$, and consist of muscovite, biotite and chlorite. Muscovite appears as euhedral crystals $150 \mu \mathrm{m}$ in size and has an aspect ratio up to 15 . Biotite is subhedral to anhedral and finer in sample PO (up to $30 \mu \mathrm{m}$ in size with an aspect ratio of around one). In the Lotharheil Schiefer (LO) biotite is subhedral, shows a grain size up to $100 \mu \mathrm{m}$ and an aspect ratio of around three. Euhedral hexagonally shaped crystals of chlorite are less frequent and around $30 \mu \mathrm{m}$ in size.

Calcite appears as anhedral crystals generally $80 \mu \mathrm{m}$ in size. Sometimes it exhibits a poikiloblastic texture in the LO (patchy-shaped grains) ranging in size between 150 and $300 \mu \mathrm{m}$, partially surrounding grains of quartz and muscovite. The normative abundance is higher in the LO (5.5 wt\%). Very coarse calcite crystals are also found occurring as veins in the PO (e.g.: one calcite vein is $2.8 \mathrm{~mm}$ in length and $0.16 \mathrm{~mm}$ wide). 
Accessory minerals include euhedral apatite and zircon, and anhedral to subhedral magnetite and pyrite. They are disseminated throughout the rock and show very fine grain sizes up to $20 \mu \mathrm{m}$.

\subsubsection{Opaque minerals}

The opaque minerals present in all the slates include magnetite, chalcopyrite and pyrite. Their shapes, proportion and distribution vary widely from slate to slate.

In the dolomitic slates the opaques mainly consist of magnetite and pyrite. Magnetite appears in almost all samples as 5 to $20 \mu \mathrm{m}$ anhedral to euhedral crystals, normally disseminated in the rock. Pyrite usually appears as 5 to $20 \mu \mathrm{m}$ anhedral crystals. In some of the samples, relatively coarser (350 to $500 \mu \mathrm{m})$ euhedral crystals are present, in veins or in the foliation surface, especially in the black varieties (U33, U45 and UY-85) and in a non-fissile variety (U38M) (Fig. 4.5g). Chalcopyrite is present in two of the samples as euhedral crystals 5 to $20 \mu \mathrm{m}$ in size.

Magnetite and pyrite are also the main opaque constituents of the pelitic slates. These two minerals are present as very fine-grained disseminated crystals (around $20 \mu \mathrm{m})$. Pyrite tends to be euhedral and magnetite subhedral to anhedral. However, in the variety Ardósia de Canelas (PL) the fine-grained pyrite crystals (20 $\mu \mathrm{m})$ occur in lenses of up to $2.6 \mathrm{~mm}$ in length and $1.0 \mathrm{~mm}$ in width.

In the Piedra laja San Luís (AR), subhedral magnetite is the dominant opaque mineral and shows two distinct grain sizes. The finer grained crystals are about 20 $\mu \mathrm{m}$ in size and the coarser grains are up to $110 \mu \mathrm{m}$. Pyrite crystals are subhedral and tend to be elongated, having a size up to $130 \mu \mathrm{m}$ with an aspect ratio of four. Their proportion in these rocks is relatively higher than for the other rocks analyzed.

Magnetite and pyrite also appear as anhedral to subhedral grains in the semipelitic slates. They have very fine grain sizes (up to $20 \mu \mathrm{m}$ ) and are evenly disseminated throughout the rocks. Pyrite is also found in veins, around $60 \mu \mathrm{m}$ thick and $15 \mathrm{~cm}$ length. Together with magnetite pyrite is also found along solution transfer surfaces. 


\subsubsection{Rock fabric}

The rock fabric together with the mineral composition controls the physical and mechanical properties and the décor of a dimensional stone, which holds true especially in the case of the slates. As illustrated in figure 4.7 four main rock fabric types have been determined for the slates analyzed. The presence of a spaced foliation is a characteristic feature common in the majority of the fabric types. This foliation is defined by cleavage domains that are essentially composed of orientated phyllosilicates and microlithons consisting of an ensemble of minerals that are in between these cleavage domains (Passchier and Trouw, 1996). According to Shelley (1993), the cleavage domains are $\mathrm{M}$ or $\mathrm{P}$ domains (for mica- or phyllosilicate-rich domains) and the microlithons are the $Q$ domains (quartz-rich domains). In the dolomitic slates the microlithons have, in addition to quartz, also a high proportion of dolomite.
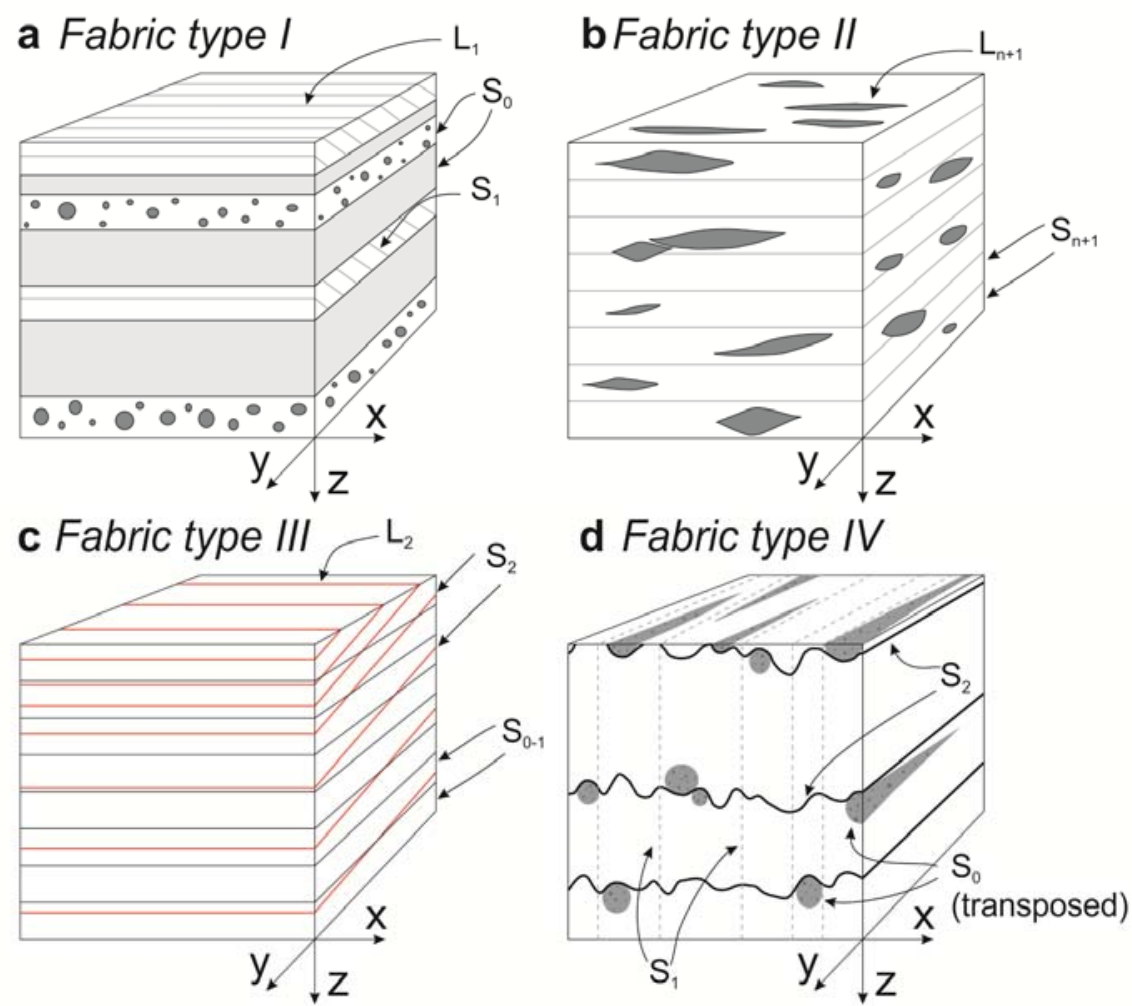

Fig. 4.7: Rock fabrics (see explanation in the text).

i. Fabric type I: the cleavage domains are practically absent or poorly developed due to the very low grade metamorphic conditions that the rock underwent. The 
rock splits parallel to the bedding plane, especially along bedding planes that are characterized by significant differences in grain sizes. These are the so-called parallel slates. The individual grains do not show any preferred orientation and are equidimensional. The slate Ardósia Gaspar (GA) is a good example for this fabric type (Fig. 4.7a). This sample shows layers that are more fine-grained, with a poorly developed $S_{1}$ foliation, which determines an intersection lineation $\left(L_{1}\right)$ with the foliation $S_{0}$.

ii. Fabric type II: is characterized by the abundance of cleavage domains determining a very well developed slaty cleavage, being the plane along which the rock splits. Individual quartz and chlorite grains of the microlithons are deformed, generally showing oblate to prolate shapes. A stretching lineation is defined by the grains that are oriented with their long axis parallel to the foliation plane. A typical example is the Spanish slate Pizarra de techar La Fraguiña (sample 120), whose fabric is illustrated schematically in figure $4.7 \mathrm{~b}$. A special case of this fabric type is the slate Ardósia de Canelas (PL), where the long axes of chloritoid porphyroblasts are perpendicular, transversal or parallel to the foliation and also millimeter thick lenses composed of tiny pyrite porphyroblasts occur. The chloritoids of Ardósia de Canelas are wrapped by the last foliation $S_{n+1}$, therefore they are pre-deformation phase $D_{n+1}$. They are post-tectonic to the foliation developed in deformation phase $D_{n}$, since they are not completely aligned.

iii. Fabric type III: A wider range of fabric types is summarized in this group. This group shows more than one foliation and the angle between the planar fabrics may differ. The main foliation, which can be described as a slaty cleavage, is generally parallel to the original bedding plane of the protolith due to transposition, e.g. in the slate Laja Negra Rufo Hnos (U45) and it is defined as $\mathrm{S}_{0 \text { - }}$ 1. In most of the cases another foliation occurs $\left(\mathrm{S}_{2}\right)$, as some of the phyllosilicate flakes were reoriented in response to a later folding event. Consequently, this kind of fabric also contains a lineation as the result of the intersection of these two foliations $\left(\mathrm{L}_{2}\right)$. If both foliations have a relatively small angle between each other (e.g. $8^{\circ}$ in sample UY-45) scales or flakes that easily break will develop. In cases 
where the angle between both foliations is larger (e.g. $15^{\circ}$ in sample U38B or $23^{\circ}$ in U38A), the main foliation shows undulations on the order of microns. In figure 4.7c this fabric is illustrated for the Uruguayan dolomitic slates. For commercial use the $S_{0-1}$ should be the dominant foliation because it controls the mechanical behavior. Additionally, the angle between both foliations should not be larger than $30^{\circ}$, because then the rock does not split easily parallel to $S_{0-1}$ and the surface obtained will not be smooth (e.g. development of steps).

iv. Fabric type IV: it is mainly characterized by the lack of flatness of the foliation surface. The most complex example is illustrated by the Xisto negro de Foz Côa (PO), which shows a foliation characterized by pressure solution and solution transfer processes and two domains with different grain sizes. The cleavage domains are composed of pyrite, muscovite and biotite and their thickness varies between $8 \mu \mathrm{m}$ and $65 \mu \mathrm{m}$. The microlithons comprise very fine-grained domains (quartz grains $<63 \mu \mathrm{m}$ ) and coarser grained domains (quartz up to $80 \mu \mathrm{m}$ ). The coarser grained domains are prolate, one to five millimeters in diameter and one to ten centimeters in length. Their long axes define a lineation parallel to the foliation plane very often surrounded by the solution transfer foliation. Another, less well-developed foliation can be observed perpendicular to the main foliation, which is characterized by pelitic domains. Additionally, carbonate, quartz and pyrite veins crosscut the rock in all directions. As for the Lotharheil Schiefer (LO), this kind of fabric is responsible for a very rough foliation surface (Fig. 4.7d).

\subsubsection{Mica layers and mass value}

The mass value is a very important parameter to be taken into account when evaluating the suitability of a slate for commercial use, as it controls its fissility. This parameter was developed by Bentz and Martini (1968) and later included in the DIN EN 12326-2.

No clear knowledge exists of how exactly the mica layers influence the flexural strength and workability of the slates. The modality for measuring the mica layers is described in European technical norm for roofing slates (DIN EN 12326-2); however, 
this parameter should be taken as an approximation. Variations of 10-15 mica layers per $\mathrm{mm}$ can occur depending on the person measuring and the procedure used (e.g. measurement with the microscope or using a printed image). Wagner (2007) calculated the mass value for several slates. This parameter is the product of the number of mica layers per $\mathrm{mm}$ by the average width of the mica layers multiplied by ten.

The values obtained for the studied slates varies from 0.12 to 8.12 , and although these values are lower when compared with those obtained by Wagner (2007), a general trend can be observed (Table 4.4 and Fig. 4.8). The dolomitic slates show lower mass values. They represent a lower number of mica layers per millimeter, between 7.5 and 39.7, and similar mica layer widths as the pelitic slates, with the exception of the Piedra laja ocre (U38A) that shows a mica layer width of $0.106 \mathrm{~mm}$.

Table 4.4: Width of mica layers, mica layers per $\mathrm{mm}$ and mass value calculated for the samples analyzed.

\begin{tabular}{cccc}
\hline Sample & $\begin{array}{c}\text { Width of } \\
\text { mica layers } \\
(\mathrm{mm})\end{array}$ & $\begin{array}{c}\text { Mica } \\
\text { layers } \\
\text { per } \mathrm{mm}\end{array}$ & $\begin{array}{c}\text { Mass } \\
\text { value }\end{array}$ \\
\hline U33 & 0.007 & 39.7 & 2.96 \\
U45 & 0.003 & 16.9 & 0.51 \\
U38A & 0.106 & 9.7 & 10.28 \\
U38B & 0.010 & 25.5 & 2.56 \\
U38C & 0.008 & 11.0 & 0.87 \\
U38D & 0.013 & 7.5 & 0.98 \\
U38M & 0.007 & 20.4 & 1.38 \\
AP & 0.010 & 2.5 & 0.25 \\
GA & 0.010 & 1.2 & 0.12 \\
AR & 0.007 & 108.4 & 7.22 \\
PL & 0.020 & 40.5 & 8.12 \\
WS & 0.011 & 55.8 & 5.99 \\
120 & 0.004 & 123.7 & 5.50 \\
150 & 0.009 & 62.8 & 5.57 \\
PO & 0.042 & 0.7 & 0.28 \\
LO & 0.032 & 0.5 & 0.16 \\
\hline
\end{tabular}

The phyllosilicate-rich pelitic slates show a very high mica layer per millimeter, between 40.5 (Ardósia de Canelas) and 123.7 (Pizarra de techar La Fraguiña). 
Although the Ardósia Gaspar and Ardósia Apiúna are pelitic slates, they have with a very low mica layer number per millimeter of 1.2 and 2.5 , respectively.

The semipelitic slates show the lowest mass values as they represent extremely low values of mica layers per millimeter, between 0.5 and 0.7 . Wagner (2007) observed that the slates with a number of mica layers per millimeter lower than 40 are not suitable as roofing and façade slates. The analyzed slates that have a higher number of mica layers per millimeter than 40 are the Spanish roofing slates (samples 120 and 150), Piedra Laja San Luis (AR), Sauerland Schiefer (SW) and Ardósia de Canelas (PL).

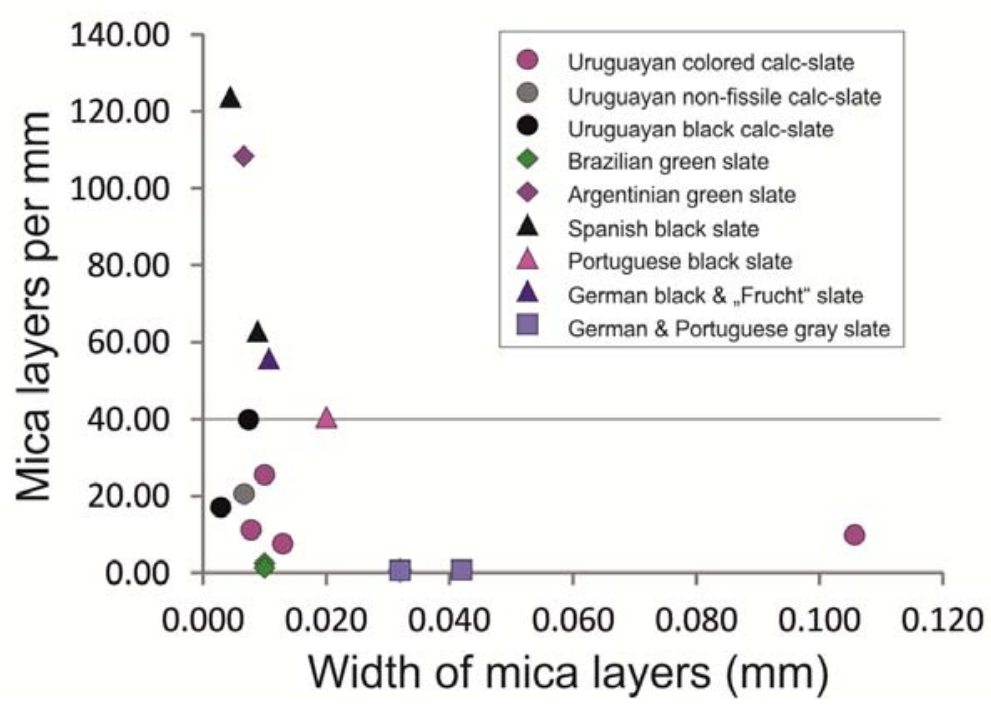

Fig. 4.8: Diagram width of mica layers versus mica layers per mm (modified after Wagner, 2007).

\subsection{Physical and mechanical rock properties}

The application of a slate is fundamentally determined by its physical and mechanical properties. The relevant properties are flexural strength, relative water uptake, temperature cycling tests, and stability during freezing, color, acid, leaching and heat. According to Wagner (2007), a low flexural strength is associated with a high water uptake. At a water uptake of about $<0.4 \mathrm{wt} \%$ a flexural strength of $50-70 \mathrm{MPa}$ is expected (see discussion in Wagner, 2007). Also a high water uptake can be related to the weathering of ore and carbonate minerals. 
4.4.1. Bulk density, matrix density, porosity

The mechanical instability or mechanical deterioration of the rock fabric, for example through frost damage or other climatic influences, is related to a high porosity, therefore a low density, but also to a high water uptake. For the application as roofing or façade cladding a comparable high flexural strength is required.

The bulk density of the investigated slates ranges from 2.72 to $2.83 \mathrm{~g} / \mathrm{cm}^{3}$ (Table 4.5). The lowest values are observed for the Ardósia Apiúna (AP) and Lotharheil Schiefer (LO), while the higher values belong to the Piedra laja verde oscura (U38C), Piedra laja verde clara (U38D) and Piedra laja verde clara "macho" (U38M).

Table 4.5: Density, porosity and pore radii distribution in the analyzed samples $\left({ }^{*}\right.$ : data after Siegesmund and Stein, 2007; ${ }^{*}:$ data after Weiss et al, $2004,{ }^{+}$: data after Fischer et al, $2011 ;{ }^{++}$: data after Naturstein Theuma AG, 2011).

\begin{tabular}{|c|c|c|c|c|c|c|c|}
\hline Trade name & ID & $\begin{array}{c}\text { Bulk } \\
\text { density } \\
\text { (g/cm3) }\end{array}$ & $\begin{array}{c}\text { Matrix } \\
\text { density } \\
\text { (g/cm3) }\end{array}$ & $\begin{array}{c}\text { Porosity } \\
\text { (\%) }\end{array}$ & $\begin{array}{c}\text { Average } \\
\text { pore } \\
\text { radii } \\
(\mu \mathrm{m})\end{array}$ & $\begin{array}{l}\text { Most } \\
\text { frequent } \\
\text { pore radii } \\
(\mu \mathrm{m})\end{array}$ & $\begin{array}{c}\text { Water } \\
\text { uptake } \\
\text { i atm. } \\
\text { (weight-\%) }\end{array}$ \\
\hline Piedra laja negra, Caorsi Hnos & U33 & 2.78 & 2.78 & 0.19 & 0.253 & 0.531 & 0.06 \\
\hline Piedra laja negra, Rufo Hnos & U45 & 2.80 & 2.81 & 0.16 & 0.010 & 0.005 & 0.05 \\
\hline Piedra laja ocre & U38A & 2.82 & 2.83 & 0.23 & 0.069 & 0.021 & 0.12 \\
\hline Piedra laja gris plomo & U38B & 2.82 & 2.83 & 0.17 & 0.056 & 0.013 & 0.07 \\
\hline Piedra laja verde oscura & U38C & 2.83 & 2.84 & 0.13 & 0.073 & 0.084 & 0.06 \\
\hline Piedra laja verde clara & U38D & 2.83 & 2.83 & 0.10 & 0.061 & 0.005 & 0.05 \\
\hline Piedra laja verde clara „macho“ & U38M & 2.83 & 2.83 & 0.26 & 0.171 & 0.021 & 0.07 \\
\hline Piedra laja Puntas del Chafalote & UY-108 & 2.72 & 2.74 & 0.62 & n.d. & n.d. & 0.24 \\
\hline Ardósia Apiúna & AP & 2.72 & 2.75 & 1.05 & 0.034 & 0.005 & 0.24 \\
\hline Ardósia Gaspar & GA & 2.75 & 2.77 & 0.59 & & & 0.09 \\
\hline Piedra Laja San Luis & $A R$ & 2.78 & 2.80 & 0.80 & 0.18 & & 0.28 \\
\hline Ardósia de Canelas & PL & 2.80 & 2.87 & 2.46 & & & 0.74 \\
\hline Sauerland Schiefer & WS & 2.77 & 2.79 & 0.51 & 0.077 & 0.008 & 0.20 \\
\hline Pizarra de techar La Fraguiña & 120 & 2.77 & 2.80 & 0.84 & 0.142 & 0.005 & 0.14 \\
\hline Pizarra de techar Valdemiguel & 150 & 2.78 & 2.79 & 0.39 & 0.310 & 0.531 & 0.16 \\
\hline Xisto negro de Foz Côa & PO & 2.74 & 2.75 & 0.42 & 0.245 & 5.309 & 0.10 \\
\hline Lotharheil Schiefer & LO & 2.72 & 2.73 & 0.30 & 0.020 & 0.005 & $0.03 *$ \\
\hline Theuma Fruchtschiefer & $\mathrm{TH}$ & $2.74 * *$ & n.d. & $0.95 * *$ & $0.096^{+}$ & $0.005^{+}$ & $0.40^{++}$ \\
\hline
\end{tabular}

The matrix density shows a similar variation, between 2.73 and $2.87 \mathrm{~g} / \mathrm{cm}^{3}$ (Table 4.5) for the Ardósia Apiúna (AP) and Lotharheil Schiefer (LO), varieties which show the lowest values. Ardósia de Canelas (PL) shows the highest matrix density 
corresponding to the high content of $\mathrm{Fe}_{2} \mathrm{O}_{3 \mathrm{t}}(10.21 \mathrm{wt} \%)$, which is mainly present as magnetite lenses parallel to the foliation.

The dolomitic slates show relatively high matrix densities, e.g. between 2.78 and 2.84 $\mathrm{g} / \mathrm{cm}^{3}$. This is due to the higher proportion of dolomite in these rocks, a mineral with a higher density $\left(2.87 \mathrm{~g} / \mathrm{cm}^{3}\right.$, Robie and Bethke, 1966) than the main constituents of slates (quartz and the chlorite group).

The porosity of the slates is normally low, between 0.10 and $2.46 \%$ (Table 4.5 ). The lowest value is registered by the Piedra laja verde oscura (U38D) and the highest is observed for the Ardósia de Canelas (2.46\%). With respect to the porosity two groups of slates can be distinguished: one group, represented by the dolomitic slates has values lower than $0.30 \%$ corresponding to a higher bulk density. The second group is represented by slates with $\geq 0.30 \%$ porosity, e.g. quartz- and phyllosilicaterich slates.

The values of the bulk density of the slates given in Table 4.5 are higher than the 75\% quartile for metamorphic rocks discussed by Mosch and Siegesmund (2007). Comparing the porosity values compiled by these authors, it is obvious that the dolomitic slates represent the upper (dolomitic slates) and lower extreme values (pelitic slates), whereas the pelitic and semipelitic varieties are the upper outliers.

The average pore radius determined by mercury injection porosimetry ranges between $0.01 \mu \mathrm{m}$ for the Piedra laja negra Rufo Hnos (U45) and $0.31 \mu \mathrm{m}$ in the Pizarra de techar Valdemiguel (150). Most pore radii range between $0.05 \mu \mathrm{m}$ and $5.31 \mu \mathrm{m}$. The lowest values are observed for the following samples, e.g.: Piedra laja negra Rufo Hnos (U45), Ardósia Apiúna (AP) and Theuma Fruchtschiefer (TH); while Xisto negro de Foz Côa (PO) exhibits the highest value. According to Klopfer (1985), in micropores with a pore diameter $<0.1 \mu \mathrm{m}$, water will condense at relative humidity $(\mathrm{RH})$ values below $99 \%$. Capillary suction is practically relevant to materials for pore diameters between $1 \mu \mathrm{m}$ and $1 \mathrm{~mm}$, the so-called capillary pores. 
The atmospheric water uptake or absorption is relatively low for all samples studied covering the range between 0.03 to $0.74 \mathrm{wt} \%$ (Table 4.5). Most of the samples show values lower than $0.30 \mathrm{wt} \%$. The exceptions are the Theuma Fruchtschiefer (TH) and the Ardósia de Canelas (PL) with values of around 0.40 wt\% (Natursteinwerk Theuma AG, 2011) and $0.74 \mathrm{wt} \%$, respectively. All the dolomitic slates show values $\leq$ $0.12 \mathrm{wt} \%$, in contrast to some pelitic and semipelitic slates (see Table 4.5).

The values of water uptake of the Uruguayan commercial slates are within the upper and lower quartile of the values for roofing slates compiled by Wagner (2007). Most of the slates belonging to the pelitic and semipelitic groups have values between both quartiles, but some of them (PL and $\mathrm{TH}$ ) show values higher than the upper quartile. If the water uptake is higher than $0.6 \mathrm{wt} \%$, the frost resistance must be determined using the DIN 52104 for 100 freeze-thaw cycles.

\subsubsection{Antimicrobial properties}

For the utilization of slates as countertops and even as cutting boards is relevant to know their antimicrobial properties. For this porpouse the studied slates were exposed to two kinds of bacteria: Escherichia coli (E. Coli) and Bacillus subtilis (B. subtilis) and a fungus: Aureobasidium pullulans (A. pullulans). Their growth after ten days was evaluated. Two kind of standard medium were used for the growing of the bacteria: lysogeny broth (LB) and potato-dextrose agar (PDA).

The results obtained are listed in Table 4.6. It is observed a lower growth of E. coli in the LB medium, being in most of the samples no growth observed. The samples that show weak growth of this bacterium are Piedra laja negra Rufo Hnos (U45) and Pizarra de techar Valdemiguel (150). Ardósia Apiúna (AP) and Piedra laja verde clara "macho" (U38M) show a moderate growth. In PDA medium a higher growth it is observed for some of the samples considered, especially in Piedra laja verde claro macho (U38M), Ardósia Apiúna (AP), Xisto negro de Foz Côa (PO) and the control sample Moskart Granite (U7), which show high growth (confluent growth of colonies). 
In the case of $B$. subtilis it is observed a higher growth for both mediums, being for most samples moderate to high, with the exception of Ardósia de Canelas (PL), which shows a weak growth. Ardósia Apiúna (AP) shows no growth in LB medium and a very high growth in PDA medium.

Table 4.6: Bacterial growth on the studied slates in different growth mediums (LB: lysogeny broth and potato-dextrose agar). Evaluation of the growth: 0: no growth, 1-2: weak to moderate, 3 : confluent growth of colonies. The last three samples are sandstone (U1), granite (U7) and marble (U27) for comparisson.

\begin{tabular}{cccc}
\hline Sample & $\begin{array}{c}\text { E. coli (LB } \\
\text { /potato- } \\
\text { dextrose) }\end{array}$ & $\begin{array}{c}\text { B. subtilis } \\
\text { (LB/potato- } \\
\text { dextrose) }\end{array}$ & $\begin{array}{c}\text { A. pullulans } \\
\text { (max. number of } \\
\text { colonies/0.25 } \mathrm{mm}^{2} \text { ) }\end{array}$ \\
\hline U33 & $0 / 0$ & $3 / 3$ & 0 \\
U45 & $1 / 2$ & $3 / 2$ & 0 \\
U38A & $0 / 2$ & $3 / 3$ & 0 \\
U38B & $0 / 0$ & $3 / 3$ & 0 \\
U38C & $0 / 0$ & $3 / 3$ & 0 \\
U38D & $0 / 0$ & $3 / 3$ & 0 \\
U38M & $2 / 3$ & $2 / 2$ & 0 \\
AP & $2 / 3$ & $0 / 3$ & $1-2$ \\
GA & $0 / 0$ & $3 / 3$ & 5 \\
AR & $0 / 2$ & $3 / 3$ & 0 \\
PL & $0 / 0$ & $1 / 1$ & 0 \\
WS & $0 / 0$ & $3 / 3$ & 0 \\
120 & $0 / 0$ & $3 / 3$ & 0 \\
150 & $1 / 2$ & $3 / 2$ & 0 \\
PO & $0 / 3$ & $3 / 2$ & 0 \\
U1 & $0 / 0$ & $2 / 2$ & 2 \\
U7 & $0 / 3$ & $3 / 3$ & $0-1$ \\
U27 & $0 / 2$ & $3 / 3$ & $0-2$ \\
\hline
\end{tabular}

For $A$. pullulans the number of colonies in $0.25 \mathrm{~mm}^{2}$ gives the information of the antimicrobial property of a slate. Most of the slates show no growth of colonies, with the exception of Ardósia Apiúna (AP) and Ardósia Gaspar (GA). The first pelitic slate show one to two colonies and GA show five, which is the highest value registered for the samples considered. The control group, composed by sandstone, granite and marble, presents zero to two colonies. 


\subsubsection{Mechanical properties}

A coordinate system determined by the foliation and lineation observed in the rocks was established. The foliation determines the $x y$-plane and the lineation the $x$ direction.

\subsubsection{Flexural strength}

The relevance of the flexural strength in any dimensional stone is because this petrophysical property determines the resistance to bending stresses, such as those experimented on with rear-ventilated façades or stairways (Siegesmund and Dürrast, 2011). According to these authors, the damages produced by the overcoming of these stresses are more important than those produced by shear or compressive stresses.

The fissility of a natural layer is a positive aspect during the manufacturing of building elements on one hand; on the other hand it is the weakest point of strength in the construction. Therefore, each contribution using fissile dimensional stones must take into account the flexural strength. Flexural strength tests have to be performed and to be compared to the potential flexural forces in the construction. This is of primary importance for the following construction elements: façade panels with lateral and back slide anchors, floor tiles with dynamic shear stress (heavy-duty loading) and construction elements with static loads within the foliation plane (e.g. columns). Minimum requirements for the thickness of construction elements are therefore dependent on the dimension of the surface in relation to the flexural strength. Also lithological and tectonically induced points of weaknesses have to be considered.

The anisotropy of the slates fabric must be carefully taken into account in the evaluation of most of their petrophysical properties. The most important fabric elements in slates are the planar structures, e.g. slaty cleavage, as they are surfaces of natural weakness, i.e. the preferred splitting direction in slates. They determine the quality and uses of these rocks, being the most important property for the production of thin tiles for roof or façade cladding. Therefore, in this investigation the flexural 
strength is only measured with the load applied perpendicular to the foliation, the zdirection as described in Siegesmund and Dürrast (2011).

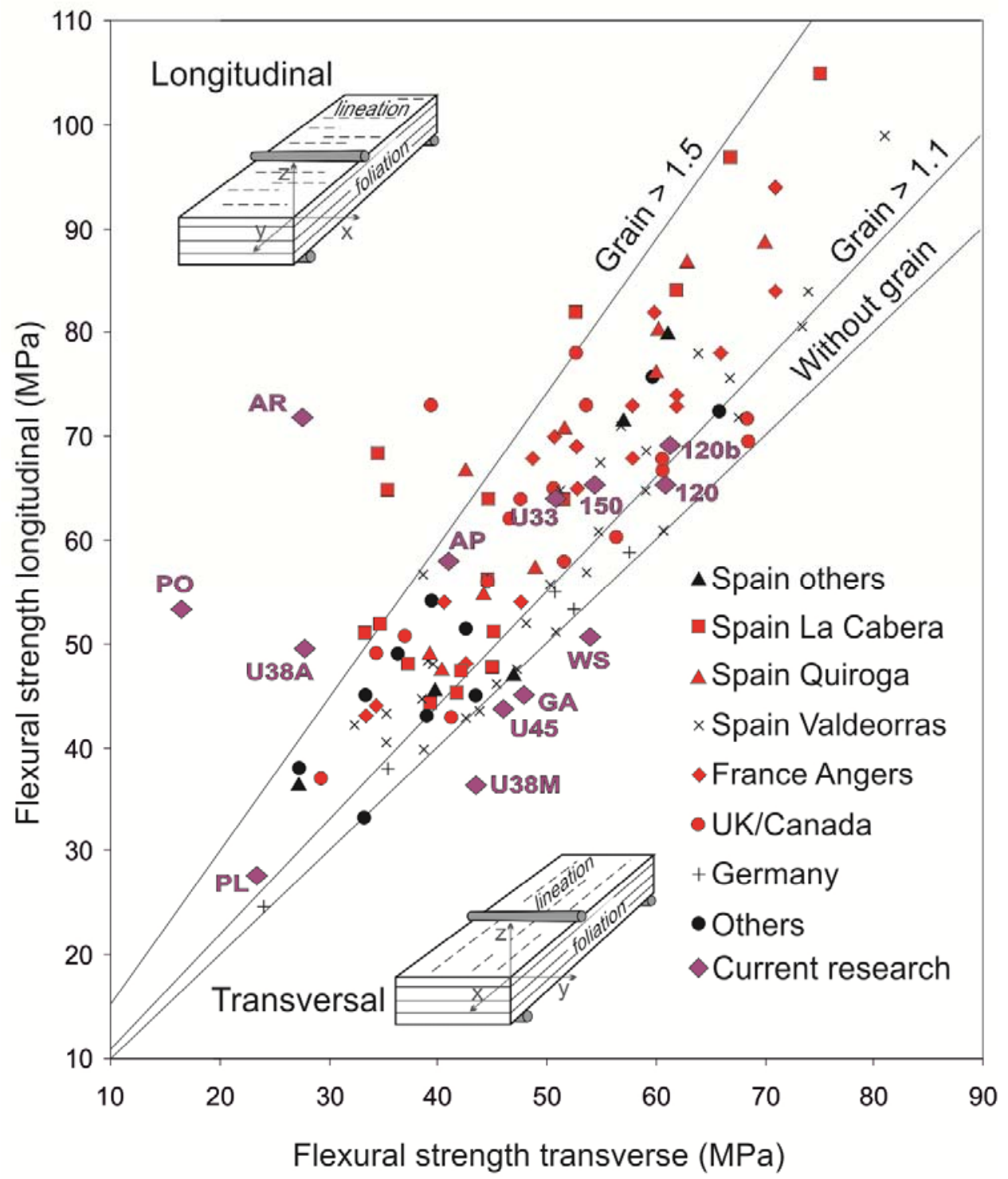

Fig. 4.9: Flexural strength transverse to lineation versus flexural strength parallel to foliation (modified after Wagner, 2007).

The presence of linear elements is also of importance because it may significantly influence the flexural strength. The lineation can be the result of the intersection of two planar elements as discussed in the subchapter rock fabrics (4.3.3.5) and illustrated in Fig. 4.7 for the dolomitic slates (U33 and U38A). Slate producers also define the lineation as "grain" (hilo in Spanish and Faden in German), which defines a penetrative lineation parallel to the $\mathrm{x}$-direction of the deformation ellipsoid (García- 
Guinea et al, 1998; Wagner 2007). In the Spanish roofing slates (La Fraguiña and Valdemiguel), the grain is defined by deformed grains of quartz and chlorite.

Considering these two main structural elements, the flexural strength was determined with the load applied perpendicular to the bedding and with the lineation parallel (longitudinal) and perpendicular (transverse) to this linear load (see Fig. 4.9). The flexural strength for the studied slates varies from 16.4 to $71.9 \mathrm{MPa}$ (Table 4.7). The lowest value of 16.4 MPa was measured in the Xisto negro de Foz Côa (PO) in the transversal direction. Piedra laja San Luis (AR) shows the highest value, 71.9 MPa, for the longitudinal direction (Mosch, 2008).

Table 4.7: Mechanical properties of the samples analyzed (*: data after Mosch, 2008; ${ }^{* *}$ : data after Siegesmund and Stein, 2007, ${ }^{+}:$data after Naturstein Theuma AG, 2011).

\begin{tabular}{|c|c|c|c|c|c|c|}
\hline \multirow[t]{2}{*}{ Trade name } & \multirow[t]{2}{*}{ ID } & \multicolumn{3}{|c|}{$\begin{array}{l}\text { Abrasion Strength } \\
\left(\mathrm{cm}^{3} / 50 \mathrm{~cm}^{2}\right)\end{array}$} & \multicolumn{2}{|c|}{$\begin{array}{c}\text { Flexural } \\
\text { Strength (MPa) }\end{array}$} \\
\hline & & $\mathbf{x}$ & y & $\mathbf{z}$ & $\mathbf{Q}$ & $\mathbf{L}$ \\
\hline Piedra laja negra, Caorsi Hnos & U33 & n.d. & n.d. & 20.6 & $50.9 \pm 5.8$ & $64.1 \pm 7.0$ \\
\hline Piedra laja nę & U45 & 10.1 & 7.6 & 8.1 & $46.0 \pm 6.0$ & $43.6 \pm 6.3$ \\
\hline Piedra & U38A & n.d. & n.d. & 10.1 & $27.7 \pm 3.2$ & $49.6 \pm 2.2$ \\
\hline Piedra la & J38B & 3.9 & 10.2 & & n.d. & n.d. \\
\hline Piedra I & U38C & n.d. & n.d. & n.d. & n.d. & n.d. \\
\hline Piedra la & U38D & n.d. & n.d. & 5.2 & n.d. & n.d. \\
\hline Piedra laja verde clara „m & U38M & n.d. & n.d. & 10.8 & $43.5 \pm 2.3$ & $36.4 \pm 1.3$ \\
\hline 'Iedra laja Puntas & UY-108 & n.d. & n.d. & 6.3 & n.d. & n.d. \\
\hline Ardósia A & AP & n.d. & n.d. & 19.4 & $41.0 \pm 8.8$ & $58.0 \pm 9.8$ \\
\hline Ardósi & GA & n.d. & n.d. & 16.8 & $48.0 \pm 11.2$ & $45.1 \pm 10.5$ \\
\hline Piedra L & AR & $6.9^{*}$ & $13.3^{*}$ & *21.2* & $27.6 \pm 3.5$ & 71.9* \\
\hline Ardósia & $\mathrm{PL}$ & n.d. & n.d. & 33.4 & $23.4 \pm 4.4$ & $27.7 \pm 4.1$ \\
\hline Sauerlan & WS & n.d. & n.d. & 33.4 & $54.0 \pm 3.4$ & $50.7 \pm 5.8$ \\
\hline Pizarra de te & 120 & n.d. & n.d. & 28.2 & $60.9 \pm 5.9$ & $65.4 \pm 3.3$ \\
\hline Pizarra de techar La Fraguiña & $120-b$ & n.d. & n.d. & n.d. & $61.3 \pm 3.4$ & $69.1 \pm 10.2$ \\
\hline Pizarra de techar Valder & 150 & n.d. & n.d. & 31.0 & $54.3 \pm 4.2$ & $65.4 \pm 5.3$ \\
\hline Xisto negro de Foz Côa & $\mathrm{PO}$ & n.d. & n.d. & 3.6 & $16.4 \pm 3.4$ & $53.3 \pm 11$ \\
\hline Lotharheil Schiefer & LO & 30.6 & (Capo & on)** & & $4.2^{* *}$ \\
\hline Theuma Fruchtschiefer & $\mathrm{TH}$ & & $.0(\mathrm{~mm}$ & & & $3.5^{+}$ \\
\hline
\end{tabular}

Wagner (2007) presented a diagram relating the values of flexural strength obtained for several slates in the two directions. All slates considered show higher values in the longitudinal direction (Fig. 4.9), which is similar to the current investigation, although in many cases the difference between both values is within the standard deviation (e.g.: Ardósia Gaspar, Pizarra de techar La Fraguiña). Nevertheless, for the 
Piedra laja verde clara "macho" (U38M), the flexural strength in the longitudinal direction is $16 \%$ lower than in the transverse direction.

The most extreme anisotropy is evidenced by Xisto negro de Foz Coa (PO), which shows a flexural strength value three times higher in the longitudinal direction than in the transverse one. This behavior is related to linear elements of the rock fabric. As described in the rock fabric subchapter, this rock represents coarser grained domains with prolate shapes that are limited by solution transfer foliation and surrounded by fine-grained domains. When the flexural load is applied parallel to the long axes of this prolate domain, the solution transfer foliation acts as cement and raises the strength of the rock. On the other hand, when the load is applied perpendicular to these prolate domains, just the contacts between the grains have to be broken, which are weaker in comparison with the solution transfer foliation.

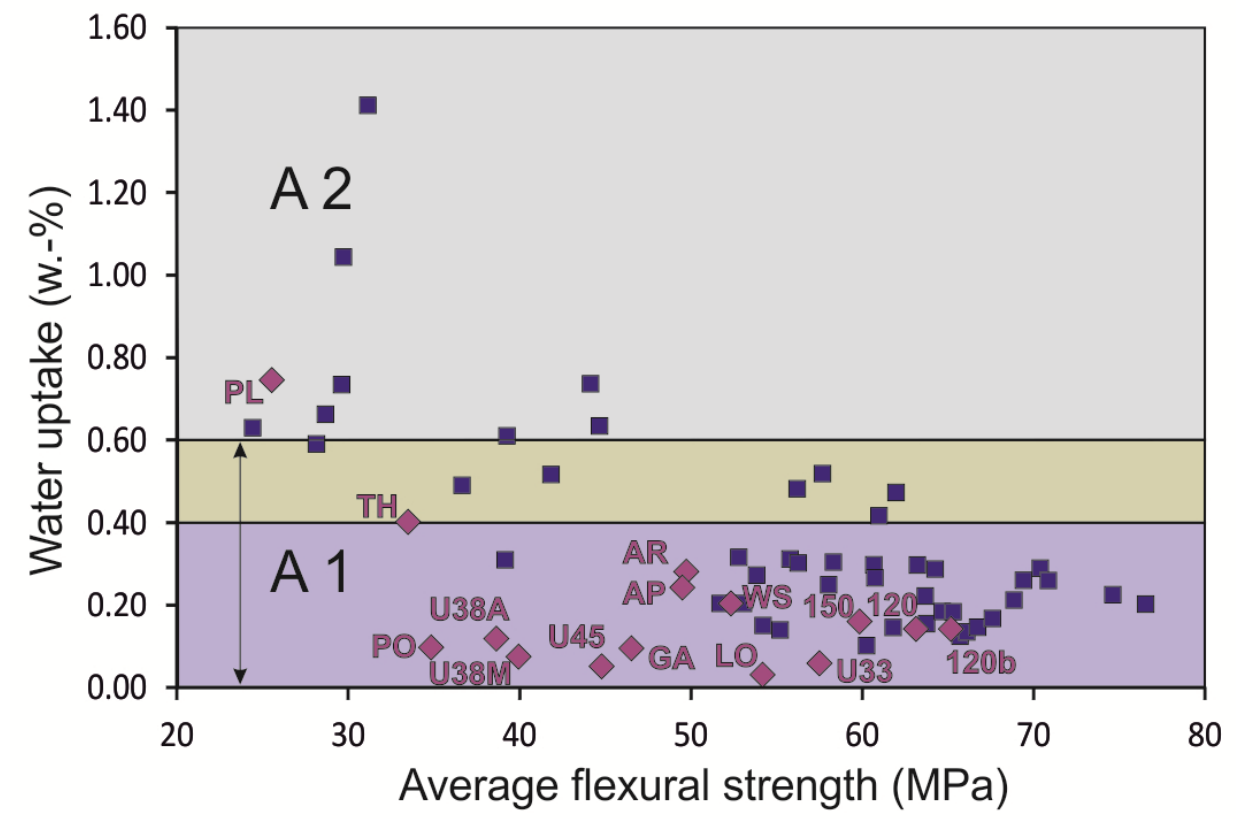

Fig. 4.10: Average flexural strength versus water uptake (modified after Wagner, 2007). (LO: data after Siegesmund and Stein, 2007; TH: data after Naturstein Theuma AG, 2011).

A negative correlation occurs between the flexural strength and water uptake as illustrated by Wagner (2007). Figure 4.10 shows this relationship. The samples showing relatively high water uptake (values higher than $0.60 \mathrm{wt} \%$ ) are the ones with the lowest flexural strength (PL). The samples showing the highest flexural strength have relatively low water uptake; generally below 0.40 wt $\%$ as seen in samples 120 , 
150 and U33. A1 and A2 are codes defined in the DIN EN 12326-1. The first comprises the slates with water uptake below $0.6 \mathrm{wt} \%$, which are freeze-thaw resistant. The second code is used when a slate has a water uptake over $0.6 \mathrm{wt} \%$. A freeze-thaw test of 100 cycles must be performed in order to prove the stability of the rock in cold climates. In addition, Wagner (2007) takes into account the NF norm used in France, whereby the resistance to freeze-thaw processes requires a water uptake below $0.4 \mathrm{wt} \%$.

All the samples analyzed in this study, with the exceptions of PL and $\mathrm{TH}$, have water uptakes below 0.4 wt\% (see Fig. 4.10). They belong to the category A1, and hence, stable against freeze-thaw phenomena.

\subsubsection{Uniaxial compressive strength}

Another important parameter to be determined for rocks is the uniaxial compressive strength (UCS), which is the maximum compressive stress in one direction until it fails. This property is especially relevant for rock elements that have to bear a planar load (Siegesmund and Dürrast, 2011), which is seldom the case in slates. Therefore, this property was determined only for two slate varieties: Piedra laja negra Rufo Hnos (U45) and Piedra laja gris plomo (U38B). For these samples the test was performed using the $x-y-z$ coordinate system (see Table 4.8). The UCS values show the maximum differences between the $\mathrm{x}$ - and $\mathrm{y}$-directions, e.g. $191 \mathrm{MPa}$ in the $\mathrm{x}$-direction and $116 \mathrm{MPa}$ in $\mathrm{y}$-direction for U45 (Table 4.8). Such anisotropy is related to the influence of the $S_{2}$ foliation, which weakens the UCS of the rock in the y-direction. This is also true for the Piedra laja San Luís (AR), whose values are between 143 $\mathrm{MPa}$ (y-direction) and $215 \mathrm{MPa}$ (x-direction) (Mosch, 2008).

The UCS values for other slates found in the literature lack orientation, and therefore, the directional dependence is unknown. For the Portuguese commercial slates the UCS values are $144 \mathrm{MPa}$ (Xisto negro de Foz Côa, PO) and $159 \mathrm{MPa}$ (Ardósia de Canelas, PL) (Laboratório Nacional de Energia e Geologia, 2012). The lowest value is $90 \mathrm{MPa}$ for the Theuma Fruchtschiefer (Natursteinwerk Theuma AG, 2012), while Siegesmund and Stein (2007) found values of around $173 \mathrm{MPa}$ for the Lotharheil 
Schiefer. All these samples can be classified as hard rock (UCS values higher than $110 \mathrm{MPa}$ ), according to the classification scheme discussed in Siegesmund and Dürrast (2011), while the Theuma Fruchtschiefer belongs to the medium hard rock.

Table 4.8: Mechanical properties of the samples analyzed ( ${ }^{*}$ : data after Mosch, 2008; ${ }^{* *}$ : data after Siegesmund and Stein, 2007).

\begin{tabular}{|c|c|c|c|c|c|c|c|c|c|c|}
\hline \multirow[t]{2}{*}{ Trade name } & \multirow[t]{2}{*}{ D } & \multicolumn{3}{|c|}{$\begin{array}{l}\text { Uniaxial compressive } \\
\text { strength (MPa) }\end{array}$} & \multicolumn{3}{|c|}{$\begin{array}{c}\text { Young's } \\
\text { modulus (GPa) }\end{array}$} & \multicolumn{3}{|c|}{$\begin{array}{c}\text { Tensile } \\
\text { strength (MPa) }\end{array}$} \\
\hline & & $\mathbf{x}$ & $y$ & z & $\mathrm{x}$ & $y$ & z & $x$ & $y$ & $z$ \\
\hline edra Laja Negra, Rufo Hnos & U45 & $191 \pm 6$ & $116 \pm 19$ & $152 \pm 23$ & $17 \pm 4$ & $18 \pm 7$ & $26 \pm 6$ & n.d. & n.d. & \\
\hline Piedra & U38B & & $130 \pm 29$ & $126 \pm 24$ & $31 \pm 10$ & $16 \pm 11$ & $16 \pm 6$ & $19 \pm 4$ & $15 \pm 3$ & \\
\hline Ardósia de Canelas & $\mathrm{PL}$ & & $159.1^{+}$ & & n.d. & n.d. & n.d. & n.d. & n.d. & \\
\hline Xisto negro & PO & & $144.0^{+}$ & & n.d. & n.d. & n.d. & n.d. & n.d. & n.c \\
\hline Piedra laja San Luis & AR & $215^{*}$ & $143^{*}$ & $159^{*}$ & n.d. & n.d. & n.d. & $21.4^{*}$ & * $10.7 *$ & 8.0 \\
\hline Lotharheil Schiefer & LO & & $172.6 * *$ & & n.d. & n.d. & n.d. & n.d. & n.d. & n. \\
\hline Theuma Fruchtschiefer & TH & & $89.8^{++}$ & & n.d. & n.d. & n.d. & n.d. & n.d. & \\
\hline
\end{tabular}

The Young's modulus ranges from $16 \mathrm{GPa}$ for the Piedra laja gris plomo (U38B) in the $y$ - and z-directions to $31 \mathrm{GPa}$ for the same variety in the x-direction. The Young's modulus values of $U 45$ are higher in the $y$ - and z-direction than in the $x$-direction, but the opposite occurs in sample U38B (see Table 4.8).

\subsubsection{Tensile strength}

Tensile strength was measured indirectly by the Brazilian method as described by Siegesmund and Dürrast (2011). Three directions ( $x, y$ and $z$ ) with respect to the foliation and lineation were analyzed for the variety Piedra laja gris plomo (U38B). In addition, the values determined by Mosch (2008) for the Piedra laja San Luis (AR) will also be discussed.

AR shows the highest values for the $\mathrm{z}$ - and $\mathrm{x}$-direction, with 8.0 and $21.4 \mathrm{MPa}$, respectively (Mosch, 2008). However, U38B shows the highest value in the $y$ direction (15 MPa) (Table 4.8). The average values for both slates are within the upper and lower quartiles of the tensile strength values, which were reported for metamorphic rocks in the data set of Mosch and Siegesmund (2007). 
For both commercial slate varieties the values in the z-direction are the lowest and the ones in the x-direction are the highest. This anisotropy is to be expected, as these rocks show a very well developed slaty cleavage.

\subsubsection{Abrasion strength}

The relevance of the abrasion strength in slates, and generally in all natural stones, is mainly related to their use as floor tiles and staircases. Floor tiles are exposed to grinding forces produced by footsteps and walking, and the abrasion strength test is a method that measures the resistance of a rock against these forces (see Siegesmund and Dürrast, 2011).

The abrasion strength was performed using a Böhme abrasion testing machine. The abrasion strength of the xy-plane (parallel to the foliation) was measured for all samples analyzed, since this surface is generally used for floor cladding. In the varieties Piedra laja negra Rufo Hnos, Piedra laja gris plomo and Piedra laja San Luís the xz- and yz-plane were also measured. The results are shown in Table 7. The values measured show a large variation, between 3.6 to $33.4 \mathrm{~cm}^{3} / 50 \mathrm{~cm}^{2}$, for the Xisto negro de Foz Côa (PO) and the Sauerland Schiefer (WS), respectively. The samples that show lower abrasion strength, and therefore higher values of volume lost, between 28.2 to $33.4 \mathrm{~cm}^{3} / 50 \mathrm{~cm}^{2}$, are the slates (PL, WS, 120, 150). These rocks show the highest proportion of normative phyllosilicates, between $61 \%$ and $68 \%$. The highest abrasion strength values exhibited by the samples with the lowest proportion of normative phyllosilicates (between 22\% and 30\%) are samples PO and U38D, respectively. Therefore, a negative correlation between abrasion strength and normative phyllosilicate proportion is evident when this property is measured parallel to the foliation.

In the directions perpendicular to the foliation this correlation is not so clear. Further investigation should be done to analyze the impact of structural elements in the abrasion strength of slates.

Based on SEM investigations Strohmeyer (2003) found that the abrasion strength for highly anisotropic rocks is lower parallel to the foliation, although the total anisotropy 
is less pronounced compared with the flexural strength or tensile strength. For example, the abrasion resistance for the slate from Argentina is between 7 and 21 $\mathrm{cm}^{3} / 50 \mathrm{~cm}^{2}$ (67\% anisotropy). In the abrasion test the minerals hardly show scratching or grinding marks. The minerals apparently suffer crystal fragmentation, which ultimately leads to the disintegration of the whole mineral assembly by fabric loosening.

Considering their abrasion strength behavior slates do not form a homogeneous group when compared to granitoids or quartzites (see Siegesmund and Dürrast, 2011). The highest abrasion strength values measured for the slates (e.g. PO, U38D) allow them to be grouped between the most resistant dimensional rocks, which are the dolerites, e.g. the variety Absolute Black with an abrasion resistance of 2.2 $\mathrm{cm}^{3} / 50 \mathrm{~cm}^{2}$ (Morales Demarco et al, 2011). The lower abrasion strengths measured in the analyzed slates (e.g. PL and WS) makes them similar to the group containing clay shale, porous limestone and sandstone (Siegesmund and Dürrast, 2011).

\subsubsection{Thermal and hydric expansion and freeze-thaw tests}

The influence of external environmental conditions (weather, antropologic factors) is important when considering the use of slate as a dimensional stone. High resistance is usually expected in slate, regardless of their application as roofing or façade cladding or in garden and landscaping. The causes of weathering result from thermal factors, such as changes in temperature and also the impact of snow and rain. To assess these relationships, thermal, hydric and freeze-thaw analyzes were performed.

\subsubsection{Thermal expansion}

Changes in temperature can result in volume expansion or contraction of a stone. Even if the temperature changes are not large, the repeated heating and cooling of stones could produce a significant deterioration over time. This holds true especially in heterogeneous rocks, e.g. with respect to the rock fabrics and the mineralogical composition. 
Thermal expansion measurements of the slates were performed using a dilatometer (for details see Strohmeyer 2003 or Koch and Siegesmund 2004). In order to simulate temperature changes comparable to those observed under natural conditions for building or ornamental stones, the temperature cycles were fixed at $90^{\circ} \mathrm{C}$. The thermal expansion was measured in three directions: one perpendicular to the foliation (z-direction) and two parallel to it ( $x$ - and $y$-direction). The values measured for thermal expansion (Table 4.9) vary from 7.0 to $13.3{ }^{*} 10^{-6} \mathrm{~K}^{-1}$ for the Ardósia de Canelas (PL) and the Piedra laja gris plomo (U38B), respectively.

In the $x$ - and $y$-direction the values are generally lower than in the $z$-direction (perpendicular to the slaty cleavage), between 8.5 and $10.3 * 10^{-6} \mathrm{~K}^{-1}$. This anisotropy is related to the preferred orientation of the phyllosilicates in these rocks. In muscovite, for example, the lowest thermal expansion coefficient is parallel to the crystallographic a-axis and the highest parallel to the c-axes: 9.9 and $13.8 * 10^{-6} \mathrm{~K}^{-1}$, respectively (Fei, 1995).

Table 4.9: Thermal and hygric expansion of the analyzed samples ( ${ }^{*}:$ data after Mosch, 2008; \#: data after Weiss et al, 2004; ${ }^{+}$: data after Siegesmund and Dürrast, 2011;).

\begin{tabular}{|c|c|c|c|c|c|c|c|}
\hline \multirow[t]{2}{*}{ Trade name } & \multirow[t]{2}{*}{ Sample } & \multicolumn{3}{|c|}{$\begin{array}{c}\text { Hydric } \\
\text { expansion } \\
(\mathrm{mm} / \mathrm{m})\end{array}$} & \multicolumn{3}{|c|}{$\begin{array}{l}\text { Thermal } \\
\text { expansion } \\
\text { coefficient } \\
\alpha\left[{ }^{*} 10^{-6} \mathrm{~K}^{-1}\right]\end{array}$} \\
\hline & & $\mathbf{x}$ & y & $\mathbf{z}$ & $\mathbf{x}$ & $\mathbf{y}$ & $\mathbf{z}$ \\
\hline Piedra laja negra, Caorsi Hnos & U33 & 0.08 & 0.03 & 0.54 & 9.0 & 9.6 & 11.7 \\
\hline Piedra laja negra, Rufo Hnos & U45 & 0.02 & 0.02 & 0.18 & 9.4 & 9.7 & 11.0 \\
\hline Piedra laja ocre & U38A & 0.01 & 0.00 & 0.51 & 9.4 & 9.8 & 10.8 \\
\hline Piedra laja gris plomo & U38B & 0.03 & 0.01 & 0.30 & 10.3 & 10.0 & 13.3 \\
\hline Piedra laja verde oscura & U38C & 0.02 & 0.07 & 0.25 & 10.1 & 8.8 & 10.3 \\
\hline Piedra laja verde clara & U38D & 0.07 & 0.04 & 0.20 & 9.6 & 9.4 & 10.6 \\
\hline Piedra laja verde clara "macho“ & “ U38M & 0.02 & 0.06 & 0.55 & 9.6 & 10.2 & 11.1 \\
\hline Ardósia Apiúna & $\mathrm{AP}$ & 0.47 & 0.79 & 1.82 & 8.6 & 9.0 & 8.5 \\
\hline Ardósia Gaspar & GA & 0.10 & 0.10 & 0.92 & 8.6 & 9.3 & 10.3 \\
\hline Piedra Laja San Luis & AR & 0.07 & 0.03 & 1.18 & $9.5^{*}$ & $9.9 *$ & $11.8^{*}$ \\
\hline Ardósia de Canelas & $\mathrm{PL}$ & 0.17 & 0.35 & 6.75 & 9.4 & 9.3 & 7.0 \\
\hline Sauerland Schiefer & WS & 0.03 & 0.04 & 2.68 & 8.5 & 9.1 & 10.7 \\
\hline Pizarra de techar La Fraguiña & 120 & 0.01 & 0.01 & 1.32 & 9.1 & 10.0 & 12.3 \\
\hline Pizarra de techar Valdemiguel & 150 & 0.01 & 0.01 & 1.32 & 8.9 & 9.2 & 11.7 \\
\hline Xisto negro de Foz Côa & PO & 0.03 & 0.09 & 0.16 & 9.5 & 9.7 & 9.8 \\
\hline Lotharheil Schiefer & LO & n.d. & 0.09 & 0.13 & n.d. & 10.1 & 10.4 \\
\hline Theuma Fruchtschiefer & $\mathrm{TH}$ & $0.15^{\#}$ & n.d. & $1.45^{\#}$ & $9.8^{+}$ & $9.3^{+}$ & $12.1^{+}$ \\
\hline
\end{tabular}


Exceptions are the Ardósia Apiúna (AP) and Ardósia de Canelas (PL). AP is more or less isotropic when comparing the three measured directions (Table 4.9), while PL exhibits anisotropy of around $25 \%$. Although muscovite crystals are oriented parallel to the slaty cleavage in the Ardósia Apiúna (AP), biotite is randomly distributed and it may be responsible for the more or less isotropic behavior. The anisotropic behavior of PL can be explained by the chloritoid porphyroblasts, which are oriented with their long axes perpendicular, transversal or parallel to the foliation. Ivaldi et al (1988) found that chloritoid is an anisotropic mineral with respect to thermal properties.

The dolomitic slates show slightly higher values perpendicular to the foliation than the pelitic and semipelitic slates. This could be related to a higher thermal expansion coefficient in dolomite, superposing the effect of the oriented phyllosilicates in the whole rock behavior. Dolomite shows thermal expansion anisotropy, being higher parallel to the c-axis than parallel to the a-axes (Reeder and Markgraf, 1986; Weiss et al, 2004).

To summarize, the values given in Table 4.9 are in agreement with those compiled by Siegesmund and Dürrast (2011) for slates. According to these authors, their thermal expansion varies between 9.3 and $12.8 * 10^{-6} \mathrm{~K}^{-1}$, showing also higher values in the z-direction.

The residual strain, which is the permanent length change of a sample after the thermal expansion measurement, is between 0.02 and $-0.30 \mathrm{~mm} / \mathrm{m}$. The lowest values are observed in the Piedra laja negra Caorsi Hnos (U33) and Ardósia de Canelas (PL) and the highest in the Ardósia Apiúna (AP) and Theuma Fruchtschiefer (TH). The Theuma Fruchtschiefer contains predominantly quartz and mica and shows high thermal expansion coefficients. These minerals also have a high volume expansion coefficient. Feldspar (with a low volume expansion coefficient) is lacking. The thermal expansion curve of the Theuma Fruchtschiefer is also characterized by a dehydration reaction, which is most pronounced perpendicular to the foliation (residual strain $-0.3 \mathrm{~mm} / \mathrm{m}$ at $20^{\circ} \mathrm{C}$ ) and almost negligible parallel to the foliation (Weiss et al, 2004). 

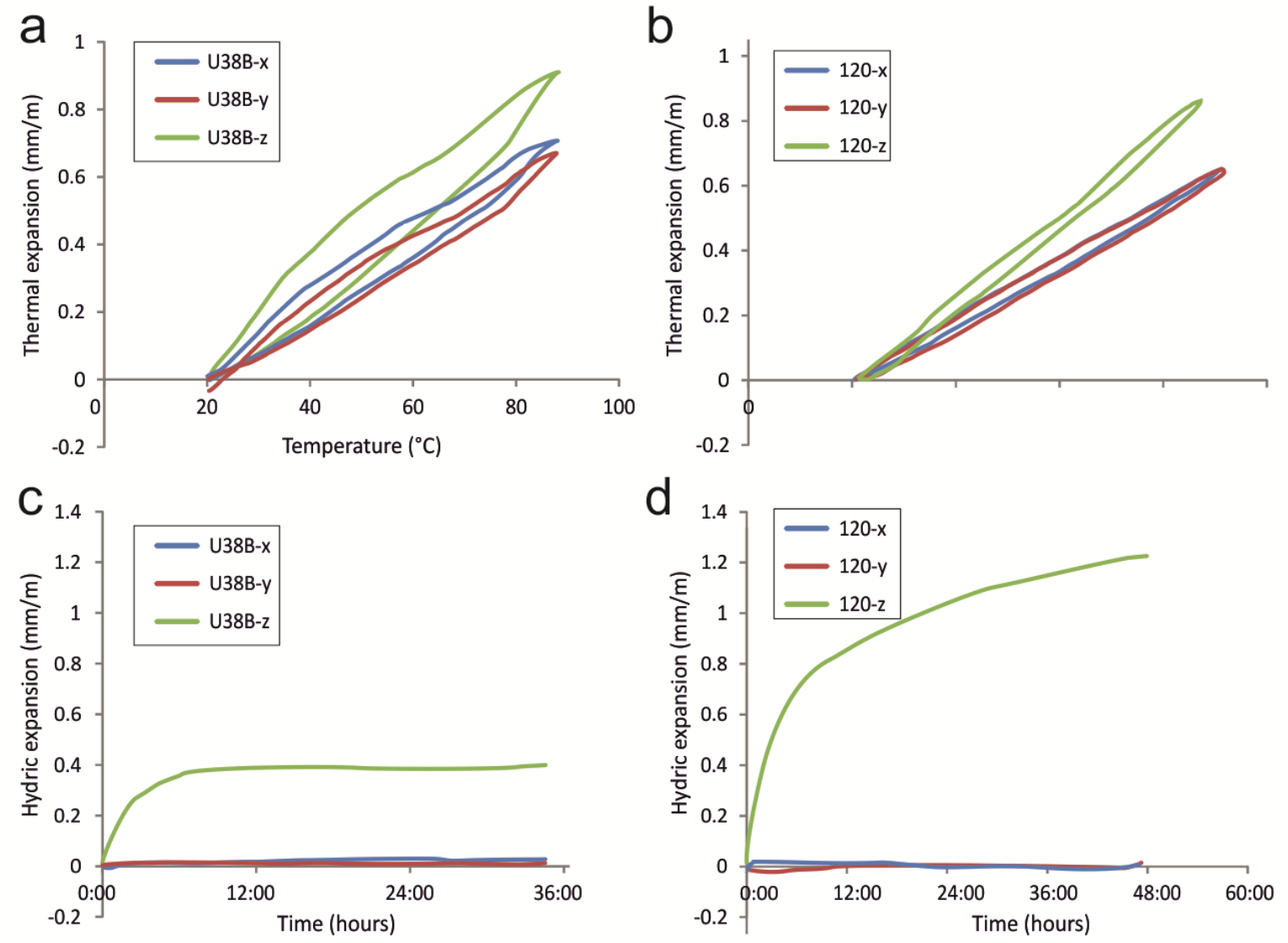

Fig. 4.11: Thermal expansion diagrams for: a. Piedra laja gris plomo (U38B) and b. Pizarra de techar La Fraguiña (120). Hydric expansion diagrams for: c. Piedra laja gris plomo (U38B) and d. Pizarra de techar La Fraguiña (120).

\subsubsection{Hydric expansion}

The hydric expansion is a measurement of the dilatation of a rock when completely submerged in water (Siegesmund and Dürrast, 2011). The weathering behavior of dimensional stones is, for these authors, strongly influenced by the processes involved in hydric expansion together with the thermal expansion.

This property was also measured using the $\mathrm{x}, \mathrm{y}$ and $\mathrm{z}$ coordinate system. The values obtained (Table 4.9 and Fig. 4.11) vary between 0.0 in the y-direction for the Piedra laja ocre (U38A) and $6.75 \mathrm{~mm} / \mathrm{m}$ in z-direction for the Ardósia de Canelas (PL). The range in $x$ - and $y$-direction is between 0.00 to $0.79 \mathrm{~mm} / \mathrm{m}$ and in the $z$-direction is between 0.13 to $6.75 \mathrm{~mm} / \mathrm{m}$. As for the thermal expansion this anisotropy is related to the preferred orientation of the phyllosilicates, the higher proportion of phyllosilicates in a slate leads to a higher hydric expansion. 
In comparison to other dimensional stones, slates show a wider range of hydric expansion, especially in the case of pelitic and semipelitic slates (Fig. 4.12). The values of hygric expansion shown by the dolomitic slates are comparable to those of marble, limestone and sandstone with the lowest hygric expansion (type I, measurments after Hockmann and Kessler, 1950).

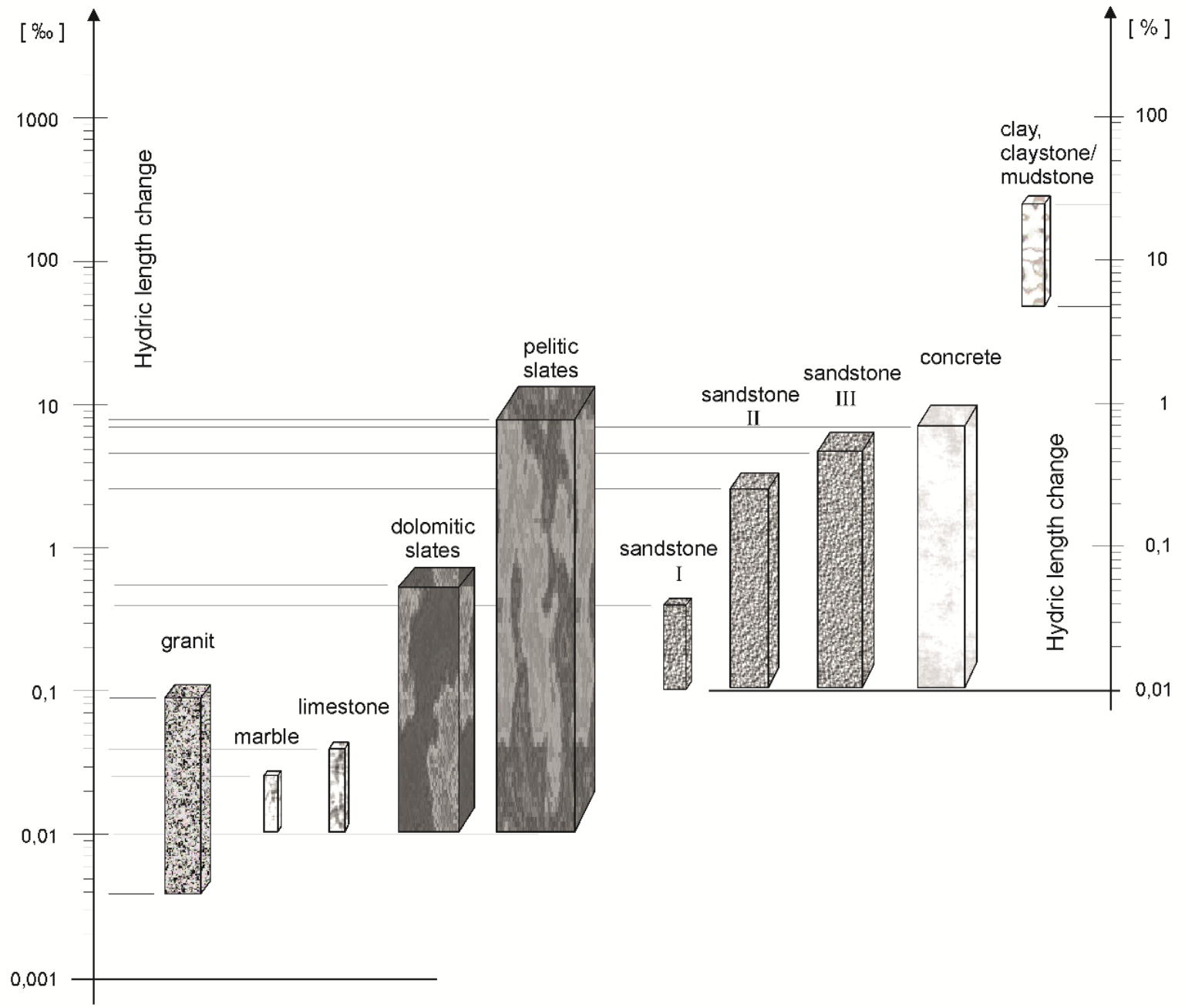

Fig. 4.12: Hydric expansion of dolomitic, pelitic and semipelitic slates in comparison to different rock types (modified after Siegesmund and Dürrast, 2011).

\subsubsection{Freeze resistance}

The freeze resistance is a very important property of dimensional stones, especially the slates. When the water uptake is higher than $0.6 \mathrm{wt} \%$, the safeness against freeze has to be determined in accordance with the DIN EN 12326:1 (2004). 
In order to know the weathering stability of the selected commercial slates in cold climates, a total of 100 freeze-thaw cycles were carried out. The weight of the samples and the Young's modulus were measured every four cycles.

The mass variation for all the slates considered is very low, as shown in Figure 4.13, between an increase of $0.01 \%$ in the Ardósia Apiúna (AP), which can be considered an experimental error, and a decrease of $0.19 \mathrm{wt} \%$ measured in the Ardósia de Canelas (PL). The samples that showed a higher weight loss (between 0.12 and 0.19 $w t \%)$ are in increasing order the Piedra laja verde oscura (U38C), Piedra laja verde clara "macho" (U38M) and the Ardósia de Canelas (PL). In the first two samples the loss of weight is determined by the dissolution of dolomite on the sample surface. This phenomenon is also visible in the other dolomitic slates. Pyrite present as veins and disseminated shows an incipient oxidation, but no color spots develop surrounding them. A variation in color is noticed for this group of slates in the sawed surfaces, but no change is perceived along the foliation surfaces.
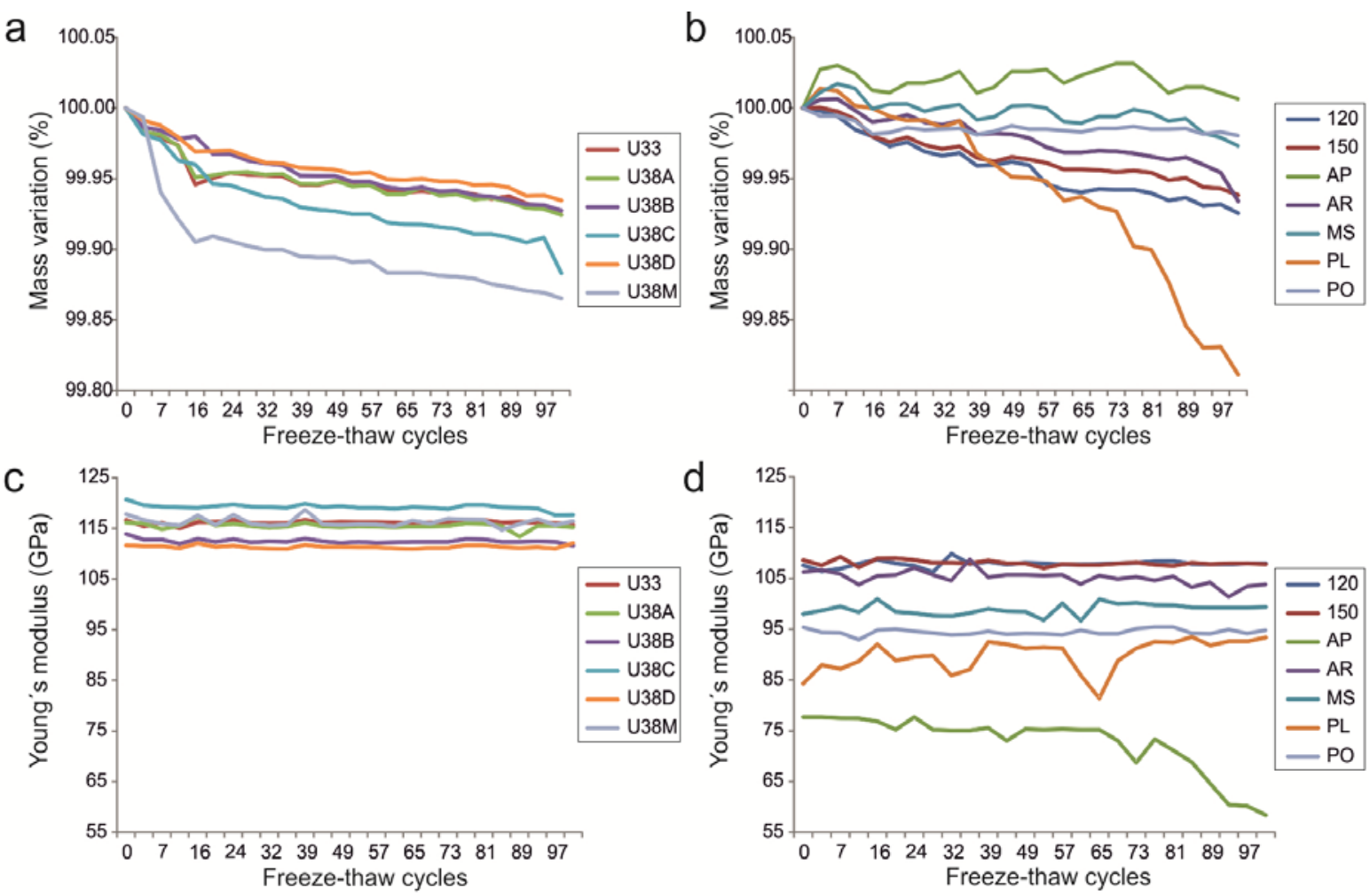

Fig. 4.13: Mass variation after 100 freeze-thaw cycles for: a. commercial dolomitic slates;

b. commercial pelitic and semipelitic slates. Young's modulus variation after 100 freeze-thaw cycles for: c. commercial dolomitic slates; d. commercial pelitic and semipelitic slates. 
In the Ardósia de Canelas an opening of the foliation surface is noted, as well as orange and white spots due to the oxidation of pyrite and precipitation of salts (probably gypsum), respectively. All these processes can explain the loss of weight in the freeze-thaw experiment. The values determined for all slates studied are very low compared to those measured by Rüdrich et al (2010) for the Habichtswald tuff but similar to those of the Kuaker limestone, Lobejuen porphyry and Knaupsholz granite.

The values for the Young's modulus range from 77.7 to $120.7 \mathrm{kN} / \mathrm{mm}^{2}$ in the Ardósia Apiúna (AP) and in the Piedra laja verde oscura (U38C), respectively (Fig. 4.13). The variation of the Young's modulus ranges between an increase of up to $10.81 \%$ in the Ardósia de Canelas (PL) and a decrease of up to $24.86 \%$ in the Ardósia Apiúna (AP).

\subsection{Deposit characterization}

\subsubsection{Regional mining districts}

The dolomitic slate deposits in Uruguay are located 25 kilometers north of the locality of Pan de Azúcar and about $100 \mathrm{~km}$ from Montevideo. There are two main dolomitic slate mining districts in the region (Fig. 4.14). The northern one is located at the source of the Arroyo Minas Viejas and is accessible from Route 60 (Arroyo Minas Viejas district: AMVD). The southern district is located at the source of the Arroyo Mataojo and accessible from Route 81 (Arroyo Mataojo district: AMD).

The dolomitic slate deposits are located in the eastern limb of a regional fold, known as the "Road 81 syncline", and are related to a second deformation phase. The mining districts are situated in the center of the Minas Viejas Association and bound to the east and west with phyllites and metabasalts. A metagabbro body crops out in the western boundary of the northern district (AMVD).

A minor slate mining district is represented by two quarries where the variety Piedra laja rosada con gris (UY-106) was mined. This district is located one kilometer east of the AMVD but in another lithological association, known as the Zanja del TigreCuchilla Alvariza Association. Another slate mining district is located in the Rocha department, represented by the slate variety Piedra laja Rocha (UY-108) and belonging to the lithological unit of the Rocha Group. 


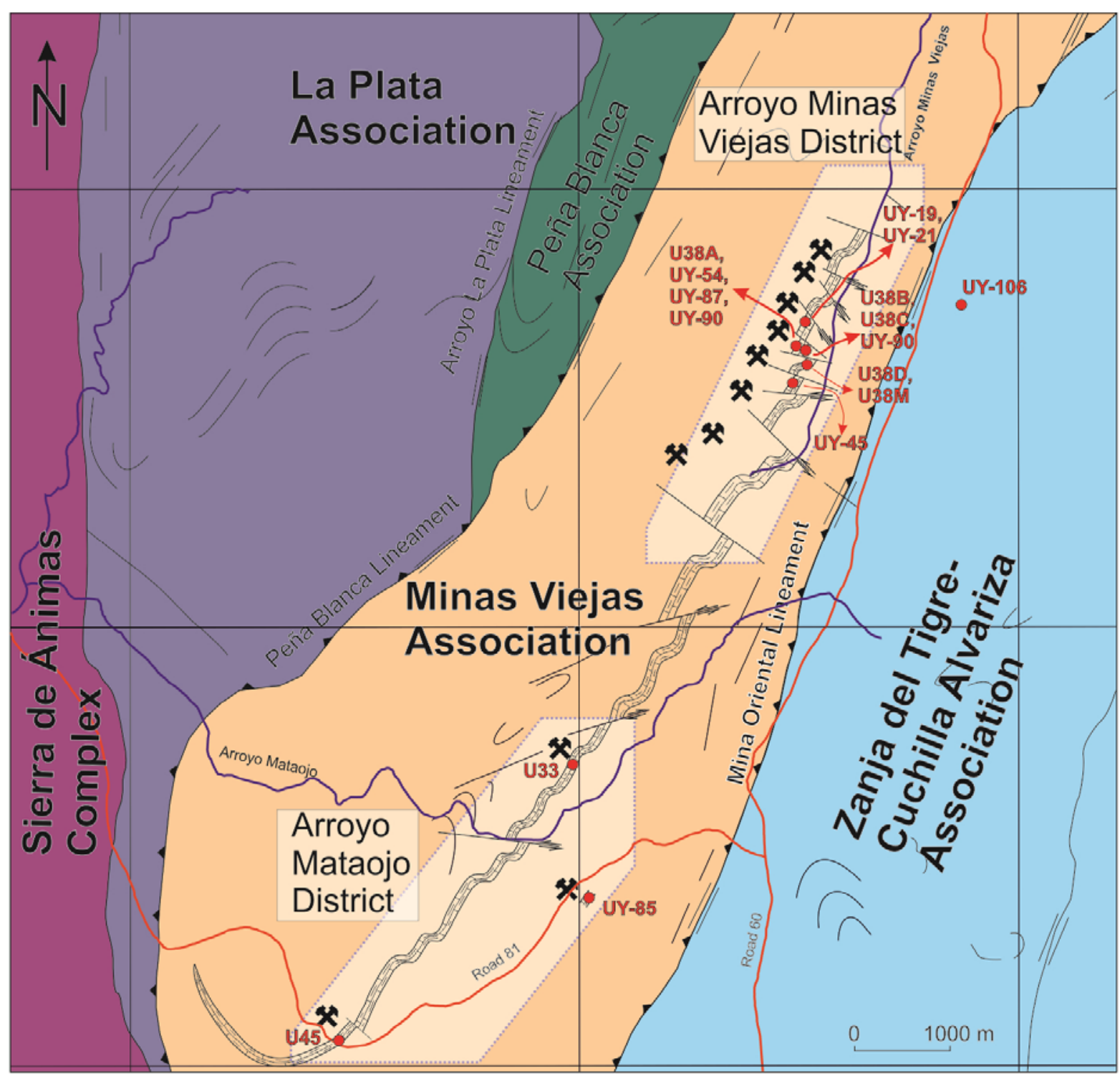

Fig. 4.14: Location of dolomitic slate mining districts in Uruguay.

The AMVD is three kilometers long in a NE-SW direction and 300 meters wide. This district is characterized by the presence of dolomitic slates showing light and dark green, red, gray and bluish gray colors. A total of 18 quarries of different sizes are located in this district, in which just four are being actively mined. About three kilometers to the southwest the Arroyo Mataojo district is located. It extends further to the southwest for about four kilometers and is $\mathbf{5 0 0}$ meters wide. Five quarries of dark gray and black dolomitic slates are found in this district, but at the present only one is active.

The dolomitic slate deposits are characterized by their elongated shape parallel to the $S_{0-1}$ foliation, which makes their mining similar to the quarrying of dikes (e.g. 
dolerite). Since the slate deposits are related to strata with a defined composition, they can be defined as stratabound deposits in the sense of Canavan (1972). To define a dolomitic slate deposit is necessary not only to find the characteristic mineral composition, but also an ensemble of structural factors that will allow their profitable mining (e.g. parallelism between $S_{0}$ and $S_{1}$, absence of highly folded sectors).

The mining districts have a width of 300 to 500 meters, however, the individual slate bodies can range between eight to 50 meters in width, but generally most show widths of around 12 meters. Their length varies between 60 and 150 meters and the current exploitation depth ranges between six to 15 meters. The northwest walls tend to be unstable, due to the fact that the foliation dips around $80^{\circ}$ to the northwest. In active quarries those walls are controlled daily to prevent collapse.

The dolomitic slates deposits in Uruguay occur in the greenschist facies volcanosedimentary Lavalleja Group, which forms part of the Dom Feliciano Belt in Uruguay. These deposits are, therefore, controlled by the regional structures that affect all the lithologies comprising this group.

\subsubsection{Structural framework and controlling factors of the deposit}

The structural framework of the studied area was investigated in detail by Midot (1984), who recognized three phases of deformation. The first phase $\left(D_{1}\right)$ generated the foliation $S_{1}$ with the oriented recrystallization of the phyllosilicates and the stretching of other minerals such as quartz, feldspar and dolomite. $S_{1}$ is described as an axial plane foliation resulting from isoclinal folding. Due to transposition, the primary foliation of these rocks $\left(S_{0}\right)$ is similar to the foliation $S_{1}$. Midot (1984) defines these foliations as $S_{0-1}$, because with few exceptions it is very difficult to distinguish them both (e.g. in intrafolial microfolds). The $S_{0-1}$ is the slaty cleavage that characterizes the dolomitic slates and creates the condition for their extraction. The cleavage dips between 70 to $90^{\circ}$ to the NW with a NNE strike (Fig. 4.15 and 4.16).

Boudinage of the carbonate and quartzite layers interlayered in the dolomitic slate body also belongs to the $D_{1}$ (Fig. 4.17a). Generally, the boudins are between two and five centimeters thick, and show extension in two directions perpendicular to one 
another, which produce irregularities in the surface of the slate. These boudins are more frequent in the AMVD, and thus create problems for the extraction of the mined slates in this district. Another structural element related to this $D_{1}$ is the mineral lineation $L_{1}$, as evidenced by the alignment of fine-grained chlorite and sericite aggregates in the foliation plane.
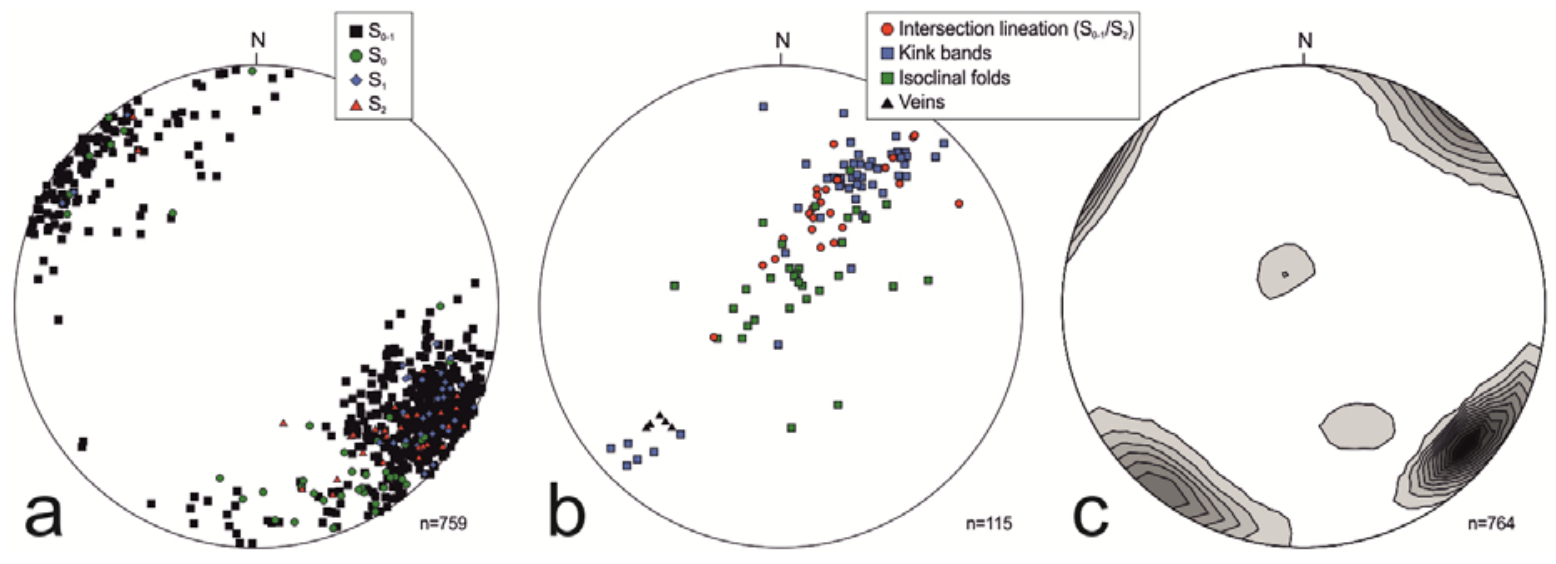

Fig. 4.15: Stereonets showing the structural elements in the dolomitic slate deposits (lower hemisphere): a. Foliations; b. Fold axes and lineations; c. Joint sets $(1,2, \ldots, 13$ multiples of random distribution).

The second deformation phase defined by Midot (1984) is a folding event, which generated folds of millimeters to kilometric in magnitude. The last ones are the most frequently recognized, e.g. the Road 81 syncline, which is one of the major folds acknowledged in the area. Midot (1984) described the structures developed in the dolomitic slates in this phase as fracture cleavage, which is the old term for disjunctive foliation or cleavage. A spaced cleavage is characterized by the presence of microlithons between the cleavage domains (Passchier and Trouw, 1996). Disjunctive foliation can evolve to "strain-slip schistosity" or, using a term with no genetic connotations: crenulation cleavage (Passchier and Trouw, 1996). This disjunctive foliation or crenulation cleavage is an axial plane foliation $\left(S_{2}\right)$ that intensely deforms the $S_{0-1}$, when the angle between both foliations is near $90^{\circ}$ (in the hinges of the folds of $D_{2}$ ). When the angle between both foliations is small, the $S_{0-1}$ surface is not affected and $S_{2}$ is parallel to $S_{0-1}$. There is no evidence of recrystallization associated to this deformation phase $D_{1}$.

Midot (1984) described the $D_{2}$ microfolds in the slates as being of two types: kink (or chevron folds) and others with more rounded and open hinges. The kink folds are 
| Case Study: Slates

asymmetric and they negatively affect the mining of the deposit, only when their amplitude is larger than $2.5 \mathrm{~cm}$ (Fig. 4.17b and c). However, these kink folds generally have smaller amplitudes (on the order of $0.5 \mathrm{~cm}$ ) and larger wavelengths (>4 meters), and therefore they do not affect the extraction of the slates.

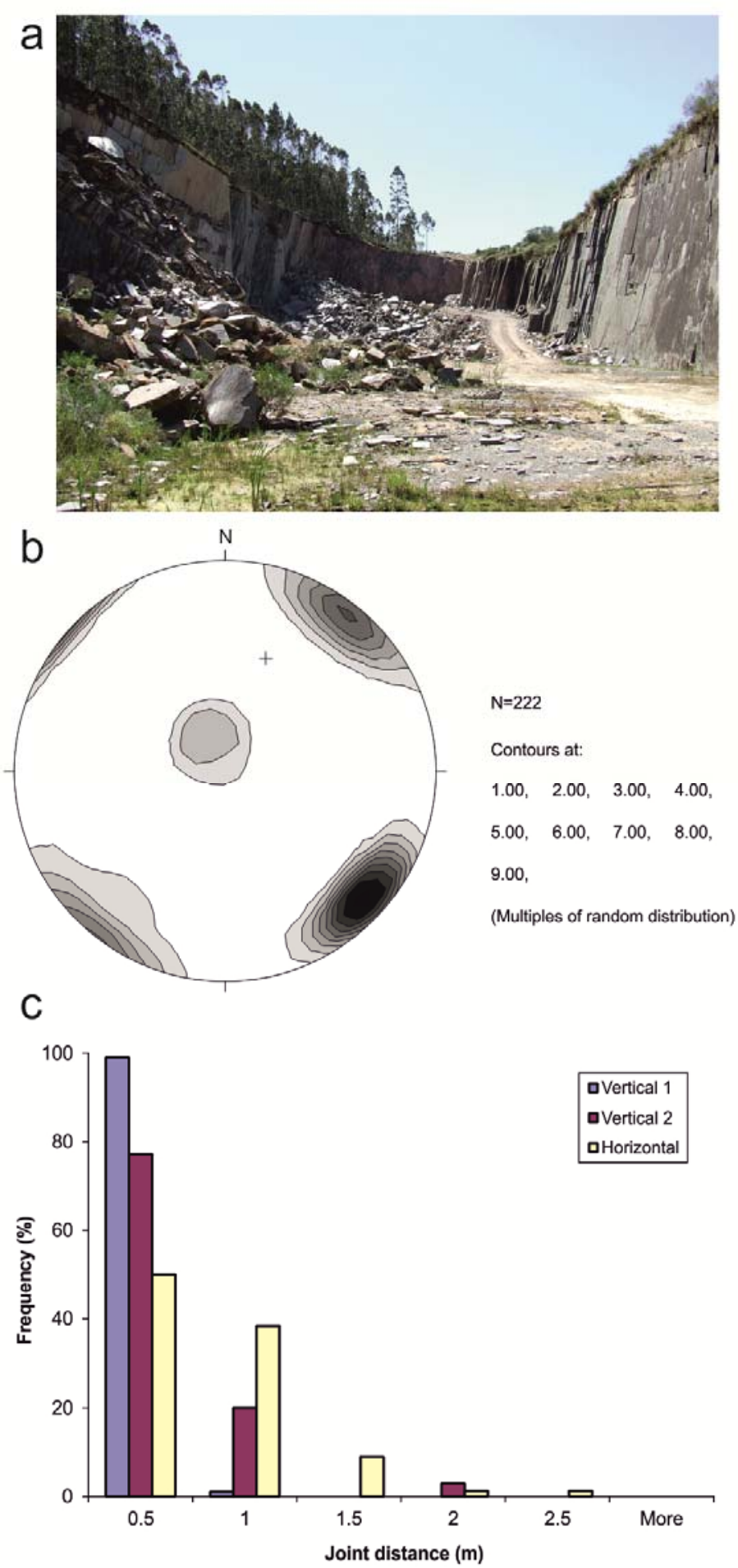

Fig. 4.16: a. Joint sets in the black calc slate (U33, Caorsi Hnos Quarry); b. Stereonet depicting the three main joint sets; c. Histogram showing joint set distribution. 
The lineation $L_{2}$ develops as the foliations $S_{0-1}$ and $S_{2}$ intersect and is parallel to the fold axes. The folds belonging to the second type are decimeters in size, but composed of a multitude of millimeter-sized microfolds that generate an embossing of the $S_{0-1}$ surface. The axes of these microfolds produce a microfolding or intersection lineation, also called $L_{2}$ by Midot (1984).

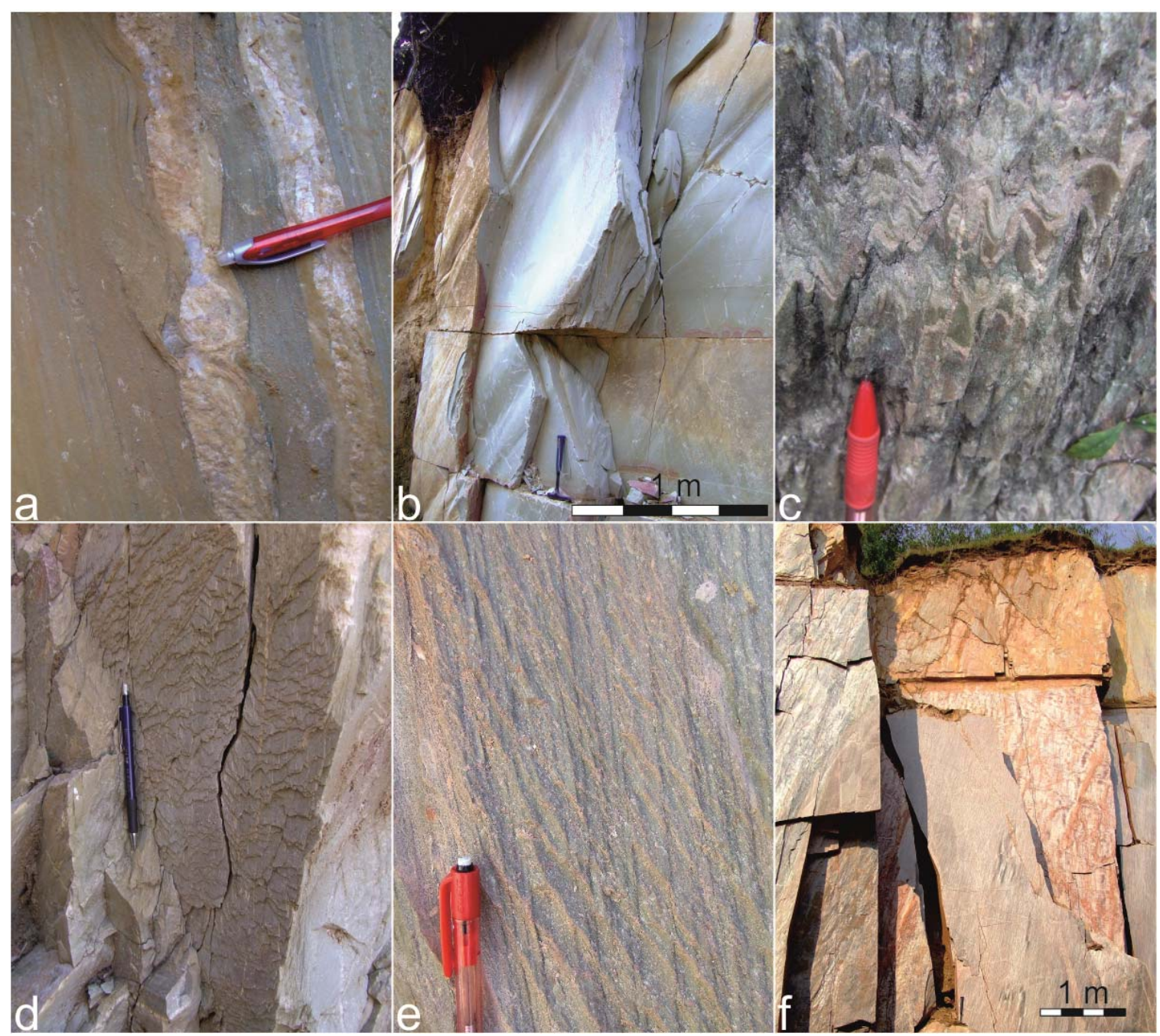

Fig. 4.17: Structural elements negatively affecting the dolomitic slate deposits in Uruguay. a. Carbonate boudins with quartz necks; $\boldsymbol{b}$. Foliation in slate showing large amplitudes and very frequent kink bands; c. Highly folded slate; $d$. Scales develop where $S_{0-1}$ and $S_{2}$ intersect at a low angle of $8^{\circ}$; e. Main foliation indicated by pencil $\left(S_{0-1}\right)$ and posterior foliation $\left(S_{2}\right)$ intersecting at approximately $30^{\circ} ;$ f. Joint systems: subhorizontal, subvertical perpendicular and parallel to the foliation.

Another element that negatively affects the quality of the mined slate in the deposits is the foliation $S_{2}$. When the angle to the foliation $S_{0-1}$ is less than $10^{\circ}$, scales will develop on the $S_{0-1}$ surface. Also when the angle between $S_{0-1}$ and $S_{2}$ is greater than 
$30^{\circ}$, the mining will be negatively affected because the slate does not split as easily through the $\mathrm{S}_{0-1}$ foliation.

Structures of the last deformation phase $\left(D_{3}\right)$ are only locally found near areas with high brittle deformation. These structures represent a second disjunctive foliation $\left(\mathrm{S}_{3}\right)$ that deforms both $S_{2}$ and $S_{0-1}$. The $S_{3}$ is vertical and is sometimes accompanied by inverse fractures dipping to the west. The frequency and intensity of $S_{3}$ determines in some cases the length of the deposits, since this $S_{3}$ foliation frequently crosscuts them.

To summarize, all these structural factors control the following aspects of the deposits:

a. width of the deposits, due to the occurrence of strongly folded sectors that progressively limit the mining on both lateral walls of a quarry;

b. length of the deposits, which determines either the occurrence of E-W strike-slip faults (dextral and sinistral) and/or boudins affecting decameter-scaled dolomitic slate bodies, both elements disrupting the continuity of these bodies;

c. depth of the mining, controlled by the dip angle of the foliation $S_{0-1}$, which determines the stability of the northwestern quarry wall.

To investigate the relationship between geochemistry of the different dolomitic slates and their mechanical response to the deformation phases, several samples have been analyzed by XRF (Tables A.4.1 and A.4.2). Samples were collected from quarry G119 (the commercial varieties U38B and U38C) and in quarry G120 (U38D and $\mathrm{U} 38 \mathrm{M})$, located ten meters to the southeast from the first quarry. The samples U38B, U38C and U38D show a very good fissility along the foliation $\mathrm{S}_{0-1}$, whereas the fissility is very poor in sample U38M. This last sample is characterized by the abundance of isoclinal folds and its inhomogeneity, defined by the intercalation of layers with coarse-grained quartz and pyrite grains, and layers with similar composition and fabric as U38D. When comparing the geochemistry of these three rocks, the main difference is in the composition of U38B, which shows more $\mathrm{SiO}_{2}$ and less $\mathrm{MgO}, \mathrm{CaO}$ and $\mathrm{CO}_{2}$ than the other three varieties. In the case of U38M it is very 
probable that the coarser grained layers affect the rheology of the rock, producing more folds and a well-developed $\mathrm{S}_{2}$.

Another example is given by quarry (G115) where the samples (U38A and UY-54) are not affected by folds, when compared with a sample located five meters southeast from the quarry wall and strongly folded (UY-87). These three rocks do not show any significant differences in their geochemistry or petrography, but they do show variations in the quality as a marketable slate.

The structural development in the dolomitic slate body (e.g. folds, boudins, faults) appears to be controlled by the preexisting rock fabric and the deformation regime. The joint systems that developed later do not necessarily affect the mining of the slates. They are generally orthogonal to one another (Fig. 4.17f) and their frequencies allow the acquisition of sufficiently large blocks (up to $50 \mathrm{~cm}$ perpendicular to the foliation and up to $4 \mathrm{~m}^{2}$ parallel to the foliation).

\subsubsection{Mining techniques in Uruguay}

The techniques used in Uruguay today for exploiting dolomitic slates do not include the most modern ones, such as the diamond wire technique. Instead small explosive charges are used to remove relatively large blocks (up to $4 \mathrm{~m}^{3}$ ). The direction of mining is perpendicular to the foliation and always from above. These blocks are reduced to smaller blocks with a pneumatic hammer in the quarry and then transported to cutting shed (Fig. 4.18a and b). There the blocks are cut to preset dimensions (e.g. 30 by $40 \mathrm{~cm}$ ) and afterwards split by hand to a desired thickness (generally $16 \mathrm{~mm}$ ) (Fig. $4.18 \mathrm{c}$ and d). 


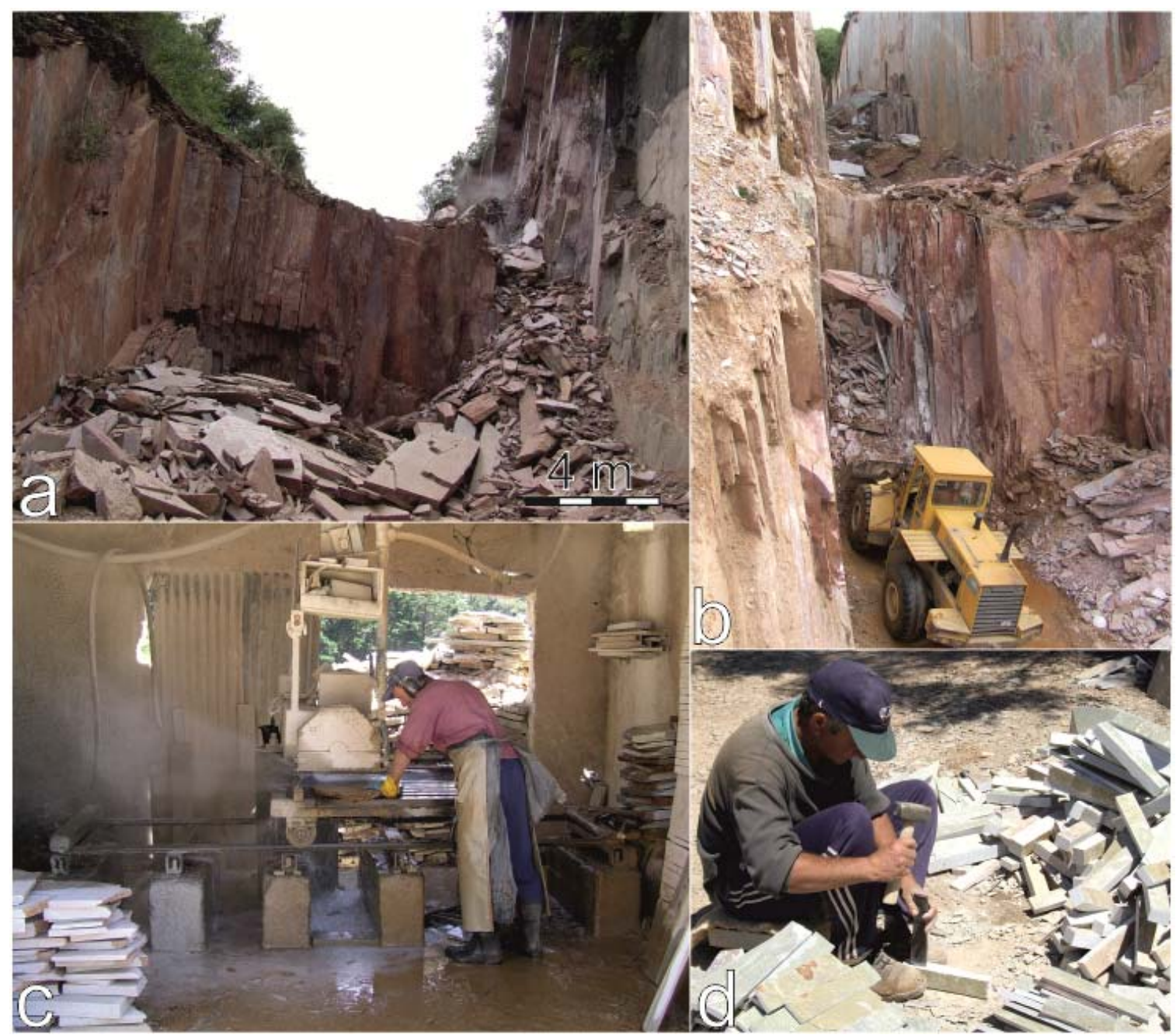

Fig. 4.18: Mining activities in a typical dolomitic slate quarry in the Arroyo Minas Viejas district (AMVD) in Uruguay (Company Carmine Rufo): a. Active slate quarry where Piedra laja ocre (U38A) is mined; b. Active slate quarry where Piedra laja gris plomo (U38B) and verde clara (U38C) are mined; c. Sawing of selected material to standard sizes; $\mathbf{d}$. Manual splitting of small tiles for wall cladding.

\subsubsection{Economic aspects}

\subsubsection{Estimation/evaluation of the deposits}

Dolomitic slate deposits are characterized by their elongated shape and relatively small sizes. The three spatial dimensions (width, length and depth) are limited by the structural controlling elements that define the geometrical distribution of the lithology of interest. No data of continuity with depth exists for the dolomitic slate deposit, however, based on the vertical exposure of the dolomitic slate body, it probably continues for at least 50 meters in depth. This is also the maximum depth for mining without taking the safety precautions into consideration, especially in cases where the deposits are very narrow. The possible occurrence of inverse fractures from the deformation $\mathrm{D}_{3}$ (Midot, 1984) could interrupt the continuity of the deposit at depth. 
A typical dolomitic slate deposit from the northern district was evaluated for its economic potential, whereby the results can be extrapolated to the other deposits in both mining districts. The chosen deposit, composed of quarries G118 and G119, is bound to the northeast and south by strike-slip faults, having a length of 400 meters. These strike-slip faults are recognizable in aerial photos and satellite images. In the field small valleys are recognizable in the deposit boundaries, which indicate the presence of faults. Furthermore, exploratory quarries have been opened near these faults and the mining was discontinued due to intensive folding (related to the major regional folds) or a very well-developed $S_{2}$ foliation (with an angle to $S_{0-1}$ of $30^{\circ}$ ), or both. The deposit width is 12 meters, being bounded by folded zones to the northwest and southeast, which produces a loss of fissility and the mining there becomes unprofitable. The raw blocks extracted from these folded zones are not suitable for the production of marketable slabs with at least $30 \mathrm{~cm}$ in length.

The deposit is separated by a fault along the middle of its length, which leads to a cessation of mining at about 30 meters. The lithologies are the same on both sides of the fault, as well as the dip and direction of the main foliation. Both sectors of the deposit have been successfully mined; the northern one corresponds to the inactive quarry $\mathrm{G} 118$, and the southern one to the active quarry $\mathrm{G} 119$.

Two color varieties are available in this deposit: Piedra laja gris plomo (U38B) cropping out as a five meter "layer" on the northwest side and Piedra laja verde oscuro (U38C), which is exposed as a seven meter "layer" on the southeast side. These varieties are designated first quality $\left(Q_{1}\right)$, meaning that they represent an excellent fissility and the plates obtained by splitting are very thin $(16 \mathrm{~mm})$. On both sides of the deposit varieties with inferior quality can be mined. The second quality is defined as $Q_{2}$, having this variety an angle between $S_{0-1}$ and $S_{2}$ larger than $30^{\circ}$, and therefore, a non-completely parallel foliation and splitting in wider plates. The third quality, $Q_{3}$, is a variety with bad fissility due to the occurrence of folds (kink bands) and a stepped foliation surface. 
Currently the depth of the deposit is 15 meters. Considering that the foliation $\mathrm{S}_{0-1}$ dips about $80^{\circ}$ to the northwest and the deposit has a maximum width of 12 meters, the maximum depth to which the mining could proceed without considering the safety risks would be 50 meters. A simplified model of the impact of the foliation dip and how it would influence the mining is illustrated in Figure 4.19. Others factors also influence the depth of mining. The depth of the water table plays an important role in mining since the annual rainfall in Uruguay is relatively high, about $1,200 \mathrm{~mm}$, which affects the pumping of water in a quarry at a 50 meter depth.

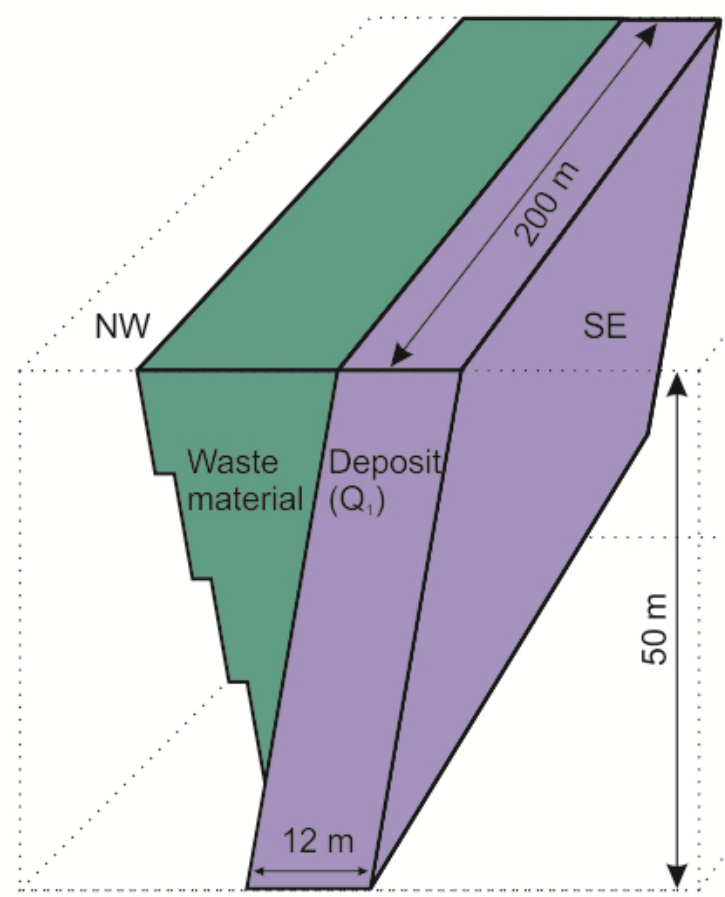

Fig. 4.19: Idealized model of a slate deposit with waste material to be extracted.

The rate of exploitation of marketable products with a quality level $Q_{1}$ is relatively low in comparison to other dimensional stone deposits. The current yield of $7 \%$ in dolomitic slates, based on international comparable deposits and the mining efficiency according to the local producers, could be considerably improved by the commercialization of the $Q_{2}$ and $Q_{3}$ varieties.

For the calculation of the reserve in the southern section of the deposit (G119) a length of 200, a width of 12 and a depth of 20 meters are considered. From a total volume of $48,000 \mathrm{~m}^{3}$ a yield of $7 \%$ is expected. Therefore, the dolomitic slate reserves in quarry $\mathrm{G} 119$ would be $3,360 \mathrm{~m}^{3}$. For the northern section of the deposit 
(G118) the length considered is $100 \mathrm{~m}$, the width and depth remain the same as in the southern section. Considering the yield of $7 \%$ again, the estimated reserves for this section are $1,680 \mathrm{~m}^{3}$. Taking into account that the material extracted will be split into slabs of $16 \mathrm{~mm}$ thickness, a production of $315,000 \mathrm{~m}^{2}$ could be expected from this deposit.

For a mining depth of 50 meters the total production of the deposit would be 12,600 $\mathrm{m}^{3}$ or $787,500 \mathrm{~m}^{2}$ (for $16 \mathrm{~mm}$ thick slabs) considering a yield of $7 \%$. Due to the instability of the northwest wall, a large amount of waste material has to be extracted in order to reach a depth of 50 meters. Around $66,150 \mathrm{~m}^{3}$ have to be extracted, so that around $15 \%$ of this material could be commercialized as second and third quality slate $\left(Q_{2}\right.$ and $\left.Q_{3}\right)$ for use as rubble stone and stone stairs. This would make an additional production of $9,920 \mathrm{~m}^{3}$.

According to DINAMIGE (2008), the total production of slates in the year 2007 was $2,073 \mathrm{~m}^{3}$ consisting of the black and colored slate varieties, where the volume production of both varieties are equal. When considering a slab thickness of $16 \mathrm{~mm}$ again, the production of colored slates is almost $75,000 \mathrm{~m}^{2}$. Around $60 \%$ of the annual colored slate production presumably comes from the deposit described and analyzed above. The mining of this deposit produces $45,000 \mathrm{~m}^{2}$ annually and when the mining only goes to a depth of 20 meters, the life of the quarry would be seven years. Using a depth of 50 meters would allow the deposit to be active for a period of 17 years and six months.

To increase the $7 \%$ yield, the raw material should be reassessed in order to transform it into a marketable product. The raw material is defined as quality $\mathrm{Q}_{2}$ and $Q_{3}$. The alternative uses for $Q_{2}$ and $Q_{3}$ are rubble stones, stone stair treads, thick polygonal slabs and irregular material for gardens (e.g. as stepping stones) and landscaping stones. The raw material that is intensively jointed, and therefore, small in size can be commercialized as tiles for indoor or outdoor cladding. Intensively folded material can also be applied as stone block steps. All these products can be sold on the local, regional (Latin America) and international markets. Other alternative uses for the local market are those which utilize the waste material 
| Case Study: Slates

resulting from the sawing. These small pieces can be reselected for the design of mosaics, for example; or be used as raw material for road construction or maintenance. For the local situation in Uruguay this has no relevancy, but the dolomitic slates show little impact to freeze-thaw and could be used without any problems in countries with colder climates.

The external factors that influence the mining costs are mainly energy (fuel), purchase of machinery, pumping of water (at 30 meters depth), salaries, cost for mining preparation and organization, environmental costs and royalty (government taxes). Credit costs are also considered in the economic costs as they are of fundamental importance for the initial investments. 
Case Study: Slates

\section{Appendix}

Table A.4.1: Major element geochemistry of the investigated slates.

\begin{tabular}{|c|c|c|c|c|c|c|c|c|c|c|c|c|c|}
\hline Sample & $\mathrm{SiO}_{2}$ & $\mathrm{TiO}_{2}$ & $\mathrm{Al}_{2} \mathrm{O}_{3}$ & $\mathrm{Fe}_{2} \mathrm{O}_{3}$ & $\mathrm{MnO}$ & $\mathrm{MgO}$ & $\mathrm{CaO}$ & $\mathrm{Na}_{2} \mathrm{O}$ & $\mathrm{K}_{2} \mathrm{O}$ & $\mathrm{P}_{2} \mathrm{O}_{5}$ & $\mathrm{H}_{2} \mathrm{O}$ & $\mathrm{CO}_{2}$ & Sum \\
\hline U33 & 42.64 & 0.405 & 9.58 & 3.51 & 0.06 & 9.81 & 11.12 & $<0.01$ & 3.21 & 0.094 & 2.15 & 16.91 & 99.49 \\
\hline U45 & 50.9 & 0.410 & 10.2 & 3.38 & 0.08 & 8.52 & 8.42 & 0.88 & 2.24 & 0.130 & 2.25 & 12.39 & 99.76 \\
\hline U38D & 30.45 & 0.244 & 6.49 & 1.9 & 0.06 & 12.8 & 17.23 & $<0.01$ & 2.04 & 0.065 & 1.61 & 26.92 & 99.81 \\
\hline U38C & 31.22 & 0.235 & 6.07 & 2.58 & 0.08 & 12.49 & 17.16 & $<0.01$ & 1.84 & 0.068 & 1.48 & 26.68 & 99.90 \\
\hline U38B & 42.48 & 0.324 & 8.64 & 4.08 & 0.06 & 9.1 & 11.88 & $<0.01$ & 2.88 & 0.088 & 1.79 & 18.41 & 99.74 \\
\hline U38A & 37.44 & 0.321 & 7.82 & 2.52 & 0.09 & 10.43 & 14.54 & $<0.01$ & 2.69 & 0.082 & 1.45 & 22.43 & 99.81 \\
\hline U38M & 32.42 & 0.258 & 6.81 & 2.23 & 0.05 & 12.38 & 16.25 & $<0.01$ & 2.09 & 0.065 & 1.6 & 25.38 & 99.54 \\
\hline UY-19 & 30.56 & 0.237 & 6.14 & 2.95 & 0.09 & 12.84 & 17.12 & $<0.01$ & 1.83 & 0.07 & 1.58 & 26.45 & 99.87 \\
\hline UY-21 & 29.15 & 0.23 & 6.2 & 3.32 & 0.09 & 12.24 & 17.66 & & 2.14 & 0.071 & 1.25 & 27.5 & 99.85 \\
\hline UY-45 & 43.55 & 0.373 & 8.47 & 2.03 & 0.05 & 10.82 & 11.84 & $<0.01$ & 2.35 & 0.127 & 2.14 & 18.04 & 99.79 \\
\hline UY-54 & 34.13 & 0.276 & 6.92 & 2.74 & 0.10 & 11.26 & 16.15 & $<0.01$ & 2.36 & 0.083 & 1.38 & 24.48 & 99.87 \\
\hline UY-85 & 40.62 & 0.271 & 6.25 & 3.44 & 0.44 & 8.28 & 14.96 & $<0.01$ & 2.36 & 0.144 & 1.37 & 21.54 & 99.68 \\
\hline UY-87 & 33.43 & & 6.56 & 2.93 & 0.09 & 11.27 & 6.16 & & 2.33 & 0.074 & 1.4 & 25.41 & 99.92 \\
\hline UY-88 & 37.33 & 0.299 & 6.79 & 3.27 & 0.11 & 11.59 & 14.15 & $<0.01$ & 1.84 & & 1.9 & 21.94 & 99.32 \\
\hline UY-90 & 30.03 & 0.236 & 6.12 & 2.54 & 0.08 & 12.27 & 17.58 & $<0.01$ & 1.97 & 0.074 & 1.27 & 27.69 & 99.86 \\
\hline UY-106 & 56.27 & 0.953 & 12.56 & 6.52 & 0.11 & 6.11 & 4.09 & $<0.01$ & 3.73 & 0.147 & 3.42 & 5.9 & 99.81 \\
\hline UY-108 & 60.92 & 0.548 & 17.22 & 4.78 & 0.09 & 1.57 & 1.44 & 1.9 & 4.64 & 0.139 & 2.24 & 4.11 & 99.60 \\
\hline $\mathrm{AP}$ & 60.24 & 0.754 & 15.37 & 5.39 & 0.29 & 1.95 & 3.87 & 2.24 & 3.4 & 0.211 & 2.78 & 3.2 & 99.70 \\
\hline AR & 61.31 & 0.742 & 17.53 & 7.43 & 0.17 & 2.51 & 0.39 & 1.37 & 4.26 & 0.117 & 3.24 & 0.53 & 99.60 \\
\hline PL & 49.91 & 1.007 & 24.49 & 10.21 & 0.08 & 2.4 & 0.24 & 0.75 & 3.16 & 0.179 & 5.46 & 1.22 & 99.10 \\
\hline GA & 62.55 & 0.825 & 17.28 & 6.5 & 0.09 & 2.13 & 0.74 & 1.95 & 4 & 0.161 & 3.27 & 0.19 & 99.69 \\
\hline WS & 56.43 & 0.912 & 18.58 & 7.63 & 0.14 & 2.86 & 0.87 & 0.89 & 3.48 & 0.136 & 4.4 & 2.69 & 99.02 \\
\hline 120 & 57.83 & 1.009 & 18.92 & 7.75 & 0.08 & 2.47 & 0.62 & 1.52 & 3.41 & 0.192 & 4.04 & 1.59 & 99.43 \\
\hline 150 & 57.71 & 1.016 & 18.95 & 7.46 & 0.08 & 2.38 & 0.57 & 1.53 & 3.46 & 0.191 & 4.49 & 1.61 & 99.44 \\
\hline $\mathrm{PO}$ & 66.93 & 0.753 & 14.61 & 4.6 & 0.05 & 2.12 & 1.33 & 2.52 & 3.42 & 0.14 & 2.12 & 0.83 & 99.42 \\
\hline LO & 71.07 & 0.581 & 10.86 & 3.34 & 0.08 & 1.18 & 3.5 & 1.25 & 2.79 & 0.132 & 1.82 & 3 & 99.60 \\
\hline
\end{tabular}

Table A.4.2: Trace element geochemistry of the investigated slates.

\begin{tabular}{cccccccccccc}
\hline Sample & $\mathrm{Ba}$ & $\mathrm{Cr}$ & $\mathrm{Ga}$ & $\mathrm{Nb}$ & $\mathrm{Ni}$ & $\mathrm{Rb}$ & $\mathrm{Sr}$ & $\mathrm{V}$ & $\mathrm{Y}$ & $\mathrm{Zn}$ & $\mathrm{Zr}$ \\
\hline U33 & 486 & 66 & 13 & 13 & 43 & 106 & 61 & 36 & 20 & 26 & 130 \\
U45 & 313 & 64 & 14 & 11 & 26 & 85 & 45 & 49 & 18 & 58 & 115 \\
U38D & 299 & 43 & 10 & $<10$ & 24 & 72 & 78 & 32 & 17 & 16 & 63 \\
U38C & 414 & 41 & $<10$ & $<10$ & 29 & 71 & 90 & 22 & 18 & 18 & 56 \\
U38B & 1009 & 47 & 10 & 10 & 35 & 119 & 73 & 43 & 19 & 16 & 77 \\
U38A & 728 & 49 & $<10$ & 11 & 34 & 95 & 55 & 37 & 17 & 13 & 99 \\
U38M & 343 & 45 & $<10$ & $<10$ & 41 & 76 & 80 & 34 & 19 & 20 & 63 \\
UY-19 & 675 & 44 & $<10$ & $<10$ & 39 & 73 & 93 & 29 & 18 & 24 & 54 \\
UY-21 & 659 & 39 & $<10$ & $<10$ & 36 & 88 & 91 & 31 & 19 & 19 & 56 \\
UY-45 & 456 & 57 & 11 & 12 & 56 & 90 & 80 & 35 & 14 & 33 & 82 \\
UY-54 & 556 & 50 & $<10$ & 10 & 36 & 83 & 58 & 35 & 19 & 12 & 70 \\
UY-85 & 315 & 39 & $<10$ & 10 & 22 & 97 & 120 & 16 & 40 & 12 & 83 \\
UY-87 & 477 & 48 & $<10$ & 11 & 37 & 82 & 85 & 29 & 18 & 14 & 77 \\
UY-88 & 3204 & 49 & $<10$ & 12 & 42 & 69 & 197 & 35 & 19 & 42 & 72 \\
UY-90 & 451 & 48 & $<10$ & 10 & 41 & 77 & 105 & 30 & 20 & 20 & 58 \\
UY-106 & 443 & 94 & 14 & 22 & 54 & 145 & 70 & 78 & 18 & 67 & 128 \\
UY-108 & 719 & 57 & 22 & 18 & 37 & 232 & 137 & 70 & 30 & 57 & 166 \\
AP & 598 & 70 & 23 & 18 & 56 & 174 & 138 & 85 & 44 & 86 & 232 \\
AR & 591 & 74 & 25 & 19 & 49 & 212 & 79 & 103 & 38 & 100 & 139 \\
PL & 536 & 135 & 31 & 20 & 85 & 158 & 177 & 169 & 39 & 169 & 99 \\
GA & 727 & 88 & 22 & 20 & 50 & 211 & 130 & 99 & 41 & 100 & 212 \\
WS & 440 & 147 & 25 & 19 & 96 & 167 & 110 & 130 & 34 & 101 & 180 \\
120 & 691 & 104 & 25 & 21 & 56 & 144 & 140 & 122 & 42 & 106 & 232 \\
150 & 711 & 106 & 24 & 22 & 56 & 149 & 139 & 135 & 41 & 102 & 223 \\
PO & 769 & 66 & 19 & 18 & 38 & 144 & 225 & 76 & 37 & 67 & 277 \\
LO & 543 & 44 & 15 & 17 & 28 & 121 & 263 & 40 & 38 & 46 & 408
\end{tabular}


Case Study: Slates

Table A.4.3: Normative minerals calculated using Slatenorm.exe (ab: albite, an: anorthite, ap: apatite, cc: calcite, ct: chloritoid, dol: dolomite, fac: daphnite, fc: greenalite, gr: graphite, ilm:

ilmenite, mac: amesite, mc: serpentine, mu: muscovite, or: orthoclase, pa: paragonite, pt: pyrite, qz: quartz, sid: siderite). Data from Theuma Fruchtschiefer $\left(\mathrm{TH}^{*}\right)$ after Fischer et al (2011).

\begin{tabular}{|c|c|c|c|c|c|c|c|c|c|c|c|c|c|c|c|c|c|c|c|}
\hline & & & & & b & & & & ic & & & & & & & $\mathrm{gr}$ & & & \\
\hline U33 & & & & & & & 00 & & & & & & & & & & & & \\
\hline & & & & & & & & & & & & & & & & & & & \\
\hline & & & & & & & & & & & & & & & & & & & \\
\hline & & & & & & & & & & & & & & & & & & & \\
\hline & & & & & & & & & & & & & & & & & & & \\
\hline & & & & & & & & & & & & & & & & & & & \\
\hline & & & & & & & & & & & & & & & & & & & \\
\hline & & & $x$ & & & & 3 & & & & & & & & & & & & \\
\hline & & & & & & & & & & & & & & & & & & & \\
\hline & & & & & & & $67 \mathrm{7}$ & & & & & & & & & & & & \\
\hline & & & & & & & 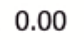 & & & & & & & & & & & & \\
\hline & & & D0 & & & & .00 & 0.0 & & 5.7 & & & & & & & & 33 & \\
\hline & & & & & & & & & & & & & & & & & & & \\
\hline & & & & & & & & & & & & & & & & & & & \\
\hline & & & & & & & 00 & & & & & & & & & & & 16 & \\
\hline & & & & & & & 68 & & & & & & & & & & & & \\
\hline & & & & & & & & & & & & & & & & & & & \\
\hline & & & & & & & 0 & $0 . C$ & & & & & & & & & & & \\
\hline & & & & & & & & & & & & & & & & & & 38 & \\
\hline & & & & & & & 0.0 & 0.0 & & 10.67 & & 0.09 & & & & ( & & 28 & \\
\hline & & & & & & & 13. & & & & & & & & & & & & \\
\hline & & & & & & & & & & & & & & & & & & & \\
\hline & & & & & & & & & & & & & & & & & & & \\
\hline & & & 7 & 0.0 & & & 0 & 0.00 & 5. & 10.29 & 00 & 0.16 & & & 0.1 & 3 & 0 & 0.45 & \\
\hline & & & & & & & & & & & & & & & & 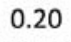 & & 33 & \\
\hline & & & & & & & & & & & & & & & & & & 31 & \\
\hline & 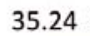 & 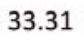 & 13.70 & & 0.00 & & & 0.01 & 0.40 & 5.25 & 0.00 & 0.00 & 0.00 & & 0.00 & 0.00 & 1.1. & 0.23 & \\
\hline
\end{tabular}


Conclusions

\section{Conclusions}

\section{General remarks}

Dimensional stones are rocks used in architecture for decorative and structural purposes because of their décor, color and petrophysical properties. The main applications of dimensional stones are as façade cladding, countertops, floor slabs, floating stairs and columns, but there are also used in the industrial sector as precision tables, in works of art like sculptures and in funerary art as gravestones.

The dimensional stones sector in Uruguay is nowadays mainly restricted to the mining, industrialization and commercialization of „black granite“ (dolerite), gray granite, dolomitic slate and sandstone. In the past colored granites (in different shades of pink, red and greenish-gray) and marbles have also been mined.

The commercialization of dimensional stones in the country starts in the beginning of the $20^{\text {th }}$ century with the mining of granites and syenitoids. The production was mainly for the local and regional market, where they have been used in the construction of representative public buildings. In the last decades some dimensional stones have been exported as it is the case for the dolerites, some gray granites and dolomitic slates. The marbles have been used mostly in the local market but in the last decades the sector is experiencing difficulties to compete with the cheaper imported marbles. The slate sector suffers from similar difficulties: After it began to develop rapidly in the middle of the $20^{\text {th }}$ century it is still nowadays active but with very modest annual production.

Geological setting and regionalization of the deposits

The Uruguayan geology allows the mining of a wide variety of dimensional stones. The most interesting geological units for the exploration and mining of dimensional stones are located in the southern area of Uruguay. Here crops out the Precambrian 
| Conclusions

basement, which is composed of magmatic and metamorphic units with a complex geological history and structural relationships.

The Precambrian basement is composed of the following tectono-stratigraphic units, from west to east: Rio de la Plata Craton (RPC) (Almeida, 1971; Oyhantçabal et al, 2011), Nico Pérez Terrane (NPT) (Bossi and Ferrando, 2001; Oyhantçabal et al, 2011), Dom Feliciano Belt (DFB) (Fragoso-Cesar, 1980) and the Punta del Este Terrane (PET) (Preciozzi et al, 1999; Basei et al, 2011). These units are separated by different tectonic discontinuities, two of them being of first order, from west to east: Sarandí del Yí and Sierra Ballena Shear Zones. The Sarandí del Yí Shear Zone (SYSZ) separates the RPC to the east and the NPT and the DFB to the west. The Sierra Ballena Shear Zone (SBSZ) bounds the NPT and the DFB to the east and the PET to the west.

After its new definition, the RPC in Uruguay corresponds to the Piedra Alta Terrane (Oyhantçabal et al, 2011) and includes metavolcano-sedimentary belts and a central granitic-gneissic complex of Paleoproterozoic age (Bossi and Ferrando, 2001; Oyhantçabal et al, 2011). This central complex is also known as Florida central granitic-gneissic belt (FCGGB) and late- to post-orogenic intrusions are widespread within this unit (Oyhantçabal et al, 2010). Several commercial granite deposits are located in these intrusions, mainly of gray granite (e.g. Chamangá, Cufré, Cuchilla del Perdido) but also of red granite (e.g. La Paz and Mahoma Red) and greenishgray granite (Moskart).

Another important unit of the Piedra Alta Terrane is the mafic dike swarm that intruded in an extensional regime all lithologies of the terrane (Bossi and Campal, 1991; Bossi and Ferrando, 2001). The age of intrusion is given by Halls et al (2001), $1790 \pm 5 \mathrm{Ma}(\mathrm{U}-\mathrm{Pb}$ on baddeleyite $)$. The commercial varieties Absolute Black and Moderate Black are mined from dolerite deposits located in this swarm. 
| Conclusions

Two other mafic rocks being potentially of interest as black dimensional stone are also located in the Piedra Alta Terrane (PAT). These are the gabbro-norite known as Mahoma Black belonging to the Guaycurú Complex (Bossi and Schipilov, 2007) and the Arapey Basalt, belonging to the Arapey Group.

Many dimensional stone deposits are located in the Dom Feliciano Belt (DFB). The syenitoid deposits (e.g. Artigas Pearl and Salmon Red syenites) are exclusively located in the Sierra de Ánimas Complex (Coronel et al, 1987; Bossi and Navarro, 2001; Morales Pérez, 2004; Oyhantçabal et al, 2007a). The Maldonado Granite deposit is located in the southern part of the DFB, directly in the SBSZ. Therefore it has the most developed features of synmagmatic deformation of all the commercial granites analyzed. In the central part of the DFB other colored commercial granite crops out: the Luján or Santa Clara Granite (Preciozzi et al, 1985; Bossi and Navarro, 2001; Bossi and Ferrando, 2001; Morales Pérez, 2004). The red-colored Guazunambí Granite crops out further to the north in the DFB (Preciozzi et al, 1985; Bossi and Navarro, 2001; Bossi and Ferrando, 2001; Morales Pérez, 2004). This granite presents a gentle foliation evidencing a less developed synmagmatic deformation compared to Maldonado Granite.

The dolomitic slates deposits are located in the southernmost portion of the Lavalleja Group (LG) (Bossi et al, 1965; Midot, 1984; Sánchez Bettucci, 1998; Sánchez Bettucci and Ramos, 1999; Oyhantçabal et al, 2001) which belongs also to the DFB. According to these authors the LG is a volcanosedimentary unit of greenschist to lower amphibolite facies metamorphism. Further subdivisions of the LG were made by Midot (1984), Sánchez Bettucci (1998) and Oyhantçabal et al (2001). The dolomitic slates compose the Fuente del Puma Formation of Midot (1984) and Sánchez Bettucci (1998) and the lithological association Minas Viejas of Oyhantçabal et al (2001)

Other gray granite deposits are located in the PET. The fine-grained varieties Cerro Áspero and Garzón granites occur in the center of this unit (Preciozzi et al, 1985). 
| Conclusions

The Santa Teresa Granite is a porphyritic granite that crops out in the east of the PET.

Case study: dolerites

The dolerites of the mafic dyke swarm represent the most relevant and promising dimensional stones from Uruguay, due to their deep black to dark gray color, homogeneous décor and the excellent quality of their petrophysical properties, as well as from the high volume of reserves potentially available. Due to their fundamental importance in the dimensional stone sector they were exemplary studied in the present work.

The dolerites comprise two geochemical and petrographic groups: $A$ and $B$. The rocks of Group A are composed of plagioclase, lower amounts of augite, exhibit a greater granophyric intergrowth, amphibole and opaques than Group B and are characterized by high $\mathrm{TiO}_{2}$ contents and an andesitic composition (Bossi and Campal, 1991; Morales Demarco et al, 2011). Group B, with a low $\mathrm{TiO}_{2}$ content, has an andesitic-basalt composition. In both groups the opaques are magnetite, ilmenite and hematite, although they differ in the total amount present and in their texture.

The black and dark gray colors of the dolerites are related with a relatively high proportion of mafic minerals (e.g. pyroxenes, amphiboles, opaque minerals) and with the occurrence of transparent plagioclase. Color measurements were performed in several internationally known black commercial granites, such as Shanxi Black from China, Star Galaxy from India and Sweden Black in order to determine the quality of the black color of the Uruguayan dolerites. The Absolute Black Dolerite from Uruguay is the darkest rock of all the samples analyzed.

The deep black homogeneous color of the Absolute Black Dolerite is determined by its mineralogy, very fine-grained subophitic texture and lack of veins. It has only been found in a small proportion in the deposits of Group A. Moderate Black Dolerite is 
| Conclusions

characterized by a medium-grained subophitic texture and a dark gray color, which is sometimes interrupted by white spots due to the presence of larger granophyric intergrowths. Light gray aplitic veins up to five centimeter in thickness are sometimes observable, but these can be easily avoided during the mining process. This variety is also commercialized as Sacramento or Oriental Black Granite and is found in groups $\mathrm{A}$ and $\mathrm{B}$.

The high densities and especially the very low porosities and pore-related properties (e.g. water absorption, water vapor diffusion) of these rocks make them a high quality granitic dimensional stones. They occupy a very favorable position in regards to their diverse applications; since they are very resistant to weathering and freezing and present no deterioration risks. The isotropic character of their petromechanical properties make possible their use as constructive elements subjected to high uniaxial applied loads, independently of the orientation of these elements. Examples include building façades, free-standing constructions in a building such as floating stairs, columns, and architraves or counter-tops. The footbridge in Bad Homburg (Germany) is a very good example of the use of this type of high strength rock, where individual blocks of Nero Assoluto dolerite from Zimbabwe are used as loadtransferring masts. Similarly, the thermal expansion is also isotropic making possible the application of these rocks as elements that require an extreme low anisotropy (e.g. precision tables). Uruguayan dolerites, therefore, can be used as constructive elements in all indoor and outdoor applications and can occupy a relevant position on the international market.

The Uruguayan black commercial granites are comparable with several worldwide known dimensional stones in regards to décor and petrophysical properties. The Absolute Black Dolerite can be compared with the Shanxi Black from China. They are similar in décor but the Uruguayan variety is slightly darker than Shanxi Black. In respect to their petrophysical properties they are very similar. Moderate Black Dolerite is comparable to the Impala Dark from South Africa. The Uruguayan dolerite has a finer grain size and higher compressive strength than the Impala Dark. 
The dolerite deposits occur in the dolerite dike swarm, which intrudes an area covering $20,000 \mathrm{~km}^{2}$ in the southwestern part of the country: the Rio de la Plata Craton. The dikes are normally not wider than 40 meters and around one kilometer long. The maximal depth reached in the quarries by the prevailing mining method is about ten meters. In similar deposits in northern China and southern Sweden depths of more than $50 \mathrm{~m}$ are possible.

The mining yield of the Uruguayan dolerite deposits, which is around $10 \%$, could be improved by an optimization of the extraction. This optimization can be performed mainly by the application of the software 3D Block Expert. The visualization of the raw blocks in three dimensions that this software allows, can be used to plan the cuts using a diamond wire saw in order to obtain the maximum block size possible.

Case study: granitoids and syenitoids

Other important group of dimensional stones in Uruguay is represented by the granitoids and syenitoids. These rocks cover a relatively wide color spectrum (gray and diverse shades of pink, red and greenish-gray), with interesting décor and very good petrophysical properties. Petrologically most of the granitoids are granites s.s., except Chamangá Granite, that is actually a granodiorite and Isla Mala Granite, which is a tonalite. The syenitoids are alkali feldspar syenite, quartz alkali feldspar syenite and quartz syenite.

The gray granitoids present a light gray color given by the combination between the gray and white feldspars, transparent quartz and mafic minerals. Their décor is mainly determined by their texture and the occurrence of dikes, mafic enclaves and other elements that disrupt the homogeneity of the color. In the present work several commercial gray granites were analyzed (e.g. Cerro Áspero, Chamangá and Maldonado granites). Generally these commercial granites show a homogeneous 
| Conclusions

décor, with the exception of Cufré, Maldonado and Santa Teresa granites, which show a magmatic foliation.

The red granites present different shades of carmine red and carmine pink, with small variations within a same variety. The red color in granitic rocks has been attributed to the presence of ferric iron oxides in the alkali feldspars that underwent a complex replacement history (Boone, 1969; Taylor, 1977; Nakano et al, 2002; Putnis et al, 2007; Plümer and Putnis, 2009). They are either medium-grained (Guazunambí Granite) or coarse-grained with porphyritic texture (La Paz and Mahoma Red granites). La Paz Granite also presents an equigranular facies.

The Moskart Granite shows a homogeneous greenish-gray to brownish-gray color and a very coarse-grained porphyritic texture. The color is attributed to chlorite, sericite, calcite and limonite filling the microcracks that affect all the minerals of this rock.

Artigas Pearl, Pan de Azúcar White, Salmon Red and Violeta Imperial belong to the syenitoid group. Similarly as for the red granites, they present feldspar replacements that together with the iron oxides (precipitated in the pores of the feldspars) are responsible for the different shades of pink, red and bluish-gray of these rocks. The exotic décor of Artigas Pearl makes it particularly interesting for the international market.

The building applications of commercial granites (granitoids and syenitoids) with higher requirements are outdoor façades and floor slabs, countertops in kitchens and bathrooms and special uses such as precision tables. For the application of commercial granites as outdoor façades are of fundamental importance the porosity and its related properties (e.g. capillary water absorption) as well as the resistance against thermal changes and freeze conditions. The absence of mafic minerals or mafic enclaves (elements that easily oxidize) is decisively in outdoor applications and in countertops, or in any other application where water and other fluids interact with 
| Conclusions

the rock. This is mainly because these minerals and enclaves oxidize and stain the original color of the rock. The Uruguayan gray granites are suitable for this application based on their low porosity, although special care must be taken with Cufré Granite, since this variety contains biotite clots and mafic enclaves that could eventually oxidize.

The syenitoids show higher porosity, capillary and unforced water absorption values, but their application as outdoor façades has proved to be safe. This can be seen in façades of 60 years old buildings in Montevideo and Buenos Aires, which until the present show no signs of stone weathering or deterioration. An exception is the Artigas Pearl Syenite, which show open pores in some polished slabs and in the deposit. For this special case a coating is necessary to prevent further deterioration.

For floor slabs and stairs the flexural and abrasion strength requirements are very relevant. All the Uruguayan granitoids and syenitoids analyzed have high abrasion strength, but the flexural strength values vary widely. The gray granites, with the higher flexural strength values clearly satisfy the demands, but this is not the case of the Moskart Granite and the syenitoids, with the exception of Salmon Red.

The block sizes that can be extracted in a quarry were calculated using two different approaches. The first one is based on arithmetic methods, such as those proposed by Singewald (1992), Palmstrøm (1982, 1996 and 2001) and Sousa (2010). These methods use the distances between the joints that compose a joint set and calculate the average or median regular block size by relatively simple calculations. The second approach is the one developed by Nikolayew et al (2007), Siegesmund et al (2007a, b) and Mosch et al (2010) and is based in the application of the software 3D Block Expert. This software calculates irregular raw block sizes using the spatial distribution of the joints in a selected quarry section. The method proposed by Sousa (2010) is the most conservative of the arithmetic methods, because it uses the median distances of the joint sets and not the average as the other two methods mentioned. The advantages of the arithmetic methods in comparison with 3D Block 
Expert is that the firsts are faster (in data collection and in the posterior analysis), require only one person to perform the data collection in the quarry, larger sections of a quarry can be analyzed and the results are sizes of regular blocks. 3D Block Expert, however, gives a 3D image of the quarry section studied, allowing a better planning of the mining operations. In the structural studies of a dimensional stone quarry both methods should be used, as they complement each other.

The sizes of the blocks calculated using the arithmetic methods for the deposits of Cerro Áspero, Chamangá, Cufré and Moskart granites are large enough to be commercialized in the dimensional stone industry for a posterior fabrication of polished slabs. An example is in the Cerro Áspero quarry number 192 where median block sizes of $3.3 \mathrm{~m}^{3}$ were obtained applying the method developed by Sousa (2010).

The Maldonado Granite, on the other hand, would only produce small blocks, which can be used as floor slabs or material for dry stone wall. The model obtained for a section of Maldonado Granite deposit using 3D Block Expert, however, led to a much larger block size, which would allow this rock to enter the dimensional stone industry for polished slabs. As described in the previous paragraph, 3D Block Expert takes in account irregular raw block sizes, while the arithmetic methods calculate regular (orthogonal) raw block. This means that the irregular raw blocks must still be squared into one, being the resulting block size smaller. Even taking this into consideration, the differences in the block sizes obtained using both methods is important and it is not believed that Maldonado Granite can offer a continuous supply of large block as required by the dimensional stone industry.

The most important syenitoid deposits, Artigas Pearl and Salmon Red, show good possibilities of providing a steady product for the dimensional stone industry, but a careful planning of the mining is essential, as these deposits present some problems. In Artigas Pearl main quarry, the arithmetic methods for calculating block sizes were applied and with the exception of the boulder zone located on the top of the deposit, the block sizes obtained are not sufficiently large when applying the most 
| Conclusions

conservative method of Sousa (2010). However, this quarry once produced large blocks and was known in the regional and international market. Further investigation should be performed in this deposit to determine the real possibilities of restarting the mining.

The Salmon Red Syenite presents the mining limitation of the occurrence of fault zones within the deposit. Here, the block sizes obtained by applying the arithmetic methods and the three-dimensional modeling are sufficiently large for the industry requirements. Using the Sousa (2010) method a regular raw block size of $4.9 \mathrm{~m}^{3}$ is calculated for the quarry 079, which is not affected by any fault zone. This is in accordance with the results obtained by modeling a section of quarry 075 with the software 3D Block Expert. The model for this quarry section determines that $85 \%$ of the total volume modeled would produce irregular raw blocks larger than $8 \mathrm{~m}^{3}$. A $60 \%$ mining yield is to be expected with a careful planning of the mining in selected sections of the Salmon Red deposit.

The Uruguayan commercial granites, such as the gray and red granitoids, have very good petrophysical quality, but their color and décor are common and already offered at very favorable prices by other countries such as China, India and Brazil. The relevance for the Uruguayan dimensional stones to enter the international market is that the regional economy is not very stable. For example the economic crisis of 2001-2002 that affected Uruguay and Argentina lead to a dramatic decrease in the dimensional stone production in Uruguay. This crisis was coincident with the international demand for yellow-colored granites. Uruguay, due to its climate, cannot provide these color varieties and could not participate in the international market for yellow granites. In 2010 the fashion changed, the colors in demand are black, red, blue and green. Uruguay has an important potential for the international market in regard to the black, red and green commercial granites.

The Uruguayan granitoids at the present economic conditions are only interesting for the local and regional market. An exception to this statement is the fine-grained light 
| Conclusions

gray variety Cerro Áspero Granite. Due to its very good petrophysical properties and relatively seldom color and décor could compete with the leading granite Padang Light from China. Other commercial granites that could enter are the syenitoids, especially Artigas Pearl and Salmon Red. Artigas Pearl shows an exotic décor, even though its petrophysical properties limit its applications. Salmon Red meanwhile presents very good petrophysical properties for a syenite and a décor that is nowadays in demand in the international market.

Case study: dolomitic slates

The Uruguayan slates, regardless of their high dolomite content (between 24.5 and $58.5 \mathrm{wt} \%$ ), present excellent petrophysical properties when compared to traditional slates such as the Spanish roofing slates. The variety of colors offered makes them very interesting for the local, regional and even for the international market.

The difficulty to determine the mineral composition of slates by conventional optical microscopy made it necessary the use of alternative approaches in the present research. These are the software "Slatenorm" that calculates the normative minerals (Prof. Dr. Dieter Jung, p. c.) and the X-ray diffraction Rietveld method. The slates were classified based on their normative mineral content with respect to the nomenclature of the British Geological Survey (Robertson, 1999). The Uruguayan slates classify mostly as dolomitic slates.

The colors of the Uruguayan slates are mainly determined by their mineralogy. They are composed of dolomite, quartz, phyllosilicates (mainly muscovite, illite and chlorite), accessory opaque minerals (e.g. magnetite and pyrite) and other accessory minerals. The gray and black dolomitic slates varieties show higher proportions of quartz and phyllosilicates, and lower contents of dolomite when compared to the green and reddish varieties. It is probable that these dark colors are related only to the phyllosilicate content and not to the higher content of quartz. The red color is attributed to the presence of patches of iron hydroxides in red and orange colors. The 
| Conclusions

greenish varieties show sometimes chlorite flakes visible to the naked eye, even though their chlorite proportion is not higher than in the other dolomitic slates.

Although the carbonate content is seen as negative for the use of slates as roofing material, these dolomitic slates have proved to be suitable for other applications. As the carbonate present is dolomite and not calcite, these rocks show a higher stability against weathering and degradation.

The most important property of a slate is its fissility. The dolomitic slates from Uruguay show a good fissility, which is directly related to the slaty foliation that this kind of rock presents. The mass value is a parameter used to quantify the mica layers present in a slate (Bentz and Martini, 1968; DIN EN 12326-2). Although it is not perfectly accurate, this parameter determines if a slate is suitable for its application as a roofing material (DIN EN 12326-2). Based on this parameter none of the Uruguayan slates can be used for this purpose and in fact there is no knowledge that they have ever been used as roofing slate.

The fabric of these dolomitic slates is composed by a main foliation (slaty cleavage), which was defined as a $\mathrm{S}_{0-1}$ by Midot (1984) and a secondary foliation $\mathrm{S}_{2}$. The angle between these two foliations is very relevant, as it determines if the rock will be suitable for commercialization. When this angle is higher than $30^{\circ}$ the rock will not easily split through the $S_{0-1}$ foliation. When it is lower than $10^{\circ}$ small scales will develop in the $S_{0-1}$ foliation, but this is not consider negative for the commercialization of the slate.

The application of a slate, as for all dimensional stones, is fundamentally determined by its physical properties. The dolomitic slates analyzed show high bulk densities (about $2.80 \mathrm{~g} / \mathrm{cm}^{3}$ ) and low porosities (lower than $0.30 \%$ ). The water absorption is also very low ( $\leq 0.12 \mathrm{wt} \%$ ), belonging to the category A1 determined by the EN DIN 52104, and hence, stable against freeze-thaw phenomena. 
| Conclusions

From the mechanical point of view these rocks can be classified as hard rock (UCS values higher than $110 \mathrm{MPa}$ ), according to the classification scheme discussed in Siegesmund and Dürrast (2011). The highest abrasion strength values measured for the slates (e.g. U38D) allow them to be grouped between the most resistant dimensional rocks, which are the dolerites, e.g. the variety Absolute Black with an abrasion resistance of $2.2 \mathrm{~cm}^{3} / 50 \mathrm{~cm}^{2}$ (Morales Demarco et al, 2011).

The thermal expansion of these rocks are comparable with sandstones (Siegesmund and Dürrast, 2011) and pelitic slates, with values between 8.8 and $13.3^{*} 10^{-6} \mathrm{~K}^{-1}$. The values of hydric expansion shown by the dolomitic slates are comparable to those of marble, limestone and sandstone reported (Hockmann and Kessler, 1950). These slates show also a high freeze resistance with losses in weight lower than $0.15 \mathrm{wt} \%$.

In comparison with other slates the Uruguayan dolomitic slates show very good petrophysical properties. With the exception of its use as roofing slates these rocks can be used in all applications. They have been traditionally used in Uruguay mainly as façade cladding and floor slabs.

The dolomitic slate crops out about $100 \mathrm{~km}$ to the northeast of Montevideo. There are two main dolomitic slate mining districts in the region: Arroyo Minas Viejas in the north and Arroyo Mataojo district in the south. They are located in the eastern limb of a regional fold (known as the "Road 81 syncline") in the center of the Minas Viejas Association and bound to the east and west with phyllites and metabasalts.

There are two other minor slate mining districts in Uruguay. One is represented by two quarries where the variety Piedra laja rosada con gris (UY-106) was mined, about one kilometer east of the Arroyo Minas Viejas District. Another slate mining district is located in the Rocha department, represented by the slate variety Piedra laja Rocha (UY-108) and belonging to the Rocha lithostratigraphic Group. 
| Conclusions

The dolomitic slate deposits are characterized by their elongated shape parallel to the $S_{0-1}$ foliation, which makes their mining similar to the quarrying of dikes (e.g. dolerite). These dolomitic slate deposits are defined as stratabound deposits in the sense of Canavan (1973). To define a dolomitic slate deposit it is necessary to find the characteristic mineral composition and mainly two structural requirements must be achieved: parallelism between $\mathrm{S}_{0-1}$ and $\mathrm{S}_{2}$ and absence of highly folded sectors.

\section{Reserves}

The mining of a deposit is mainly controlled by the three categories of the International Framework Classification of the United Nations for fossil energy and mineral reserves and resources (UN, 2010). These categories are: i. degree of favorability of social and economic conditions (e.g. market prices, relevant legal and environmental conditions) ( $E$ axis); ii. maturity of studies and commitments to implement mining plans, which will determine the feasibility of the mining project ( $F$ axis); iii. level of confidence in the geological knowledge and potential recoverability of the quantities (the $G$ axis). Commercial projects are the ones feasible from a technical, economic and social point of view.

The reserves of a mineral resource are a very important factor that will determine the feasibility of its mining. For the case of dimensional stones, the reserves calculations consider the dimension of the deposit and the mining yield (including the waste material that is possible to commercialize as aggregate).

The probable reserves for the dolerite deposits were estimated taking an average dike of $30 \mathrm{~m}$ width, $150 \mathrm{~m}$ length and a mining depth of 50 meters, a mining yield of $10 \%$ and considering the mining of 19 dikes that were determined as productive. $\mathrm{A}$ volume of $20,310 \mathrm{~m}^{3}$ was already extracted (Bossi and Campal, 1991; Morales Pérez, 2004; DINAMIGE, 2010) and, therefore, was subtracted from the reserve calculated. The present probable reserves estimated for the dolerites are $366,750 \mathrm{~m}^{3}$ for Moderate Black and 40,750 $\mathrm{m}^{3}$ for Absolute Black. 
The potential areas to be mined in each granitoid or syenitoid deposit are between 10,000 to $210,000 \mathrm{~m}^{2}$, being in general about $80,000 \mathrm{~m}^{2}$. The mining depths considered in the reserves calculation were of $10 \mathrm{~m}$ and exceptionally of $20 \mathrm{~m}$ (Salmon Red Syenite), which is conservative when compared to mining depth of similar commercial granites worldwide.

The historic mining yields in granitoid and syenitoid deposits in Uruguay were between 20 and $30 \%$. But nowadays with the new technology applied, mainly the diamond wire saw, the yields have incremented. A maximum mining yield of $60 \%$ is estimated for some of the deposits, when also taking in consideration the revaluation of the waste material for its commercialization.

The total probable reserves for three of the gray granites are $1,090,000 \mathrm{~m}^{3}$ (Cerro Áspero, Cufré and Maldonado granites) and for Moskart Granite is around 400,000 $\mathrm{m}^{3}$. For the four syenitoids analyzed the probable reserves are around $3,405,000 \mathrm{~m}^{3}$.

Considering international cubic meter prices between 200 and 300 U\$ for the finegrained granite and of $200 \mathrm{U} \$$ for the other gray granites, the total capital that the mining of their deposits could produce would be of $240,500,000 \mathrm{U} \$$. The mining of Moskart Granite deposits would led to a capital generation of 200,000,000 U\$ considering a price of $500 \mathrm{U} \$ / \mathrm{m}^{3}$. The mining of the syenites would produce an income of 1,506,000,000 U\$, considering an $\mathrm{m}^{3}$ price of $200 \mathrm{U} \$$ for the Pan de Azúcar White and of $450 \cup \$$ for the other three syenitoids.

Future development of the mining sector in Uruguay and new commercial varieties

For a further development of the mining in the deposits it would be necessary to assess their depths, since is the only direction in which the mining could proceed once the limits of the areas are defined. The best methods for this assessment are 
| Conclusions

geophysical (e.g. vertical electrical sounding and geoelectrical tomography) and perforations with drill core sampling.

Other potentially interesting rocks in Uruguay for their utilization as dimensional stones require more research in order to characterize the materials and their deposits. These researches should take into account the methods described in the present work in order to correctly evaluate the petrophysics of the materials and the viability of the mining through an analysis of the deposit characteristics, in particular the joint set frequency as it determines the block sizes that could be extracted.

Some of these potentially interesting rocks are: i. the basalt of the Arapey Group of the northwest of Uruguay, which shows a dark gray color and good petrophysical properties; ii. the Mahoma Black in Piedra Alta Terrane (southwest of Uruguay), which could be eventually commercialized as black dimensional stone for interior applications where no water is present; iii. the conglomerate of Las Ventanas Formation, associated to the Sierra de Ánimas Complex (southeast of Uruguay); iv. Tacuarembó Sandstone and other sandstones associated to the Paraná Basin (northern of Uruguay), mainly to indoor application due to their high porosity.

The future development of the dimensional stone sector in Uruguay should focus in the further evaluation of these resources in order to study all the potentially commercial varieties. For an increase in the mining yield it is of primary importance the reassessment of the waste material to transform it in aggregate and other construction materials. 


\section{General appendix: Analytical procedures}

6.1. Density and Porosity, Mercury Injection Porosimetry and Water Absorption

The standard parameters bulk density $\left(\rho_{\text {bulk }}\right)$, matrix density $\left(\rho_{\mathrm{r}}\right)$ and effective porosity (Ф) were determined as described in Hoffmann (2006) using the Archimedes Principle and relating the masses of a sample in dry $\left(\mathrm{m}_{\mathrm{d}}\right)$, wet $\left(\mathrm{m}_{\mathrm{w}}\right)$ and under water (buoyancy) $\left(m_{b}\right)$ conditions in accordance with the following equations:

$$
\rho_{\text {bulk }}=m_{d} / m_{w}-m_{b}
$$

$$
\begin{aligned}
& \rho_{m}=m_{d} / m_{d}-m_{b} \\
& \Phi=m_{w}-m_{d} / m_{w}-m_{b}
\end{aligned}
$$

The pore size distribution was measured by applying the Mercury Intrusion Porosimetry using a "Porosimeter 2000" from the Company Carlo Elba. The samples, cylinders of $10 \mathrm{~mm}$ diameter and $40 \mathrm{~mm}$ length, are placed in a cell where a vacuum is generated and afterwards filled with mercury. The mercury is then forced into the pores of the sample, by applying pressure in a progressive way. Since the pressure at which the mercury enters the pores is inversely proportional to the pore size, this is easily calculated.

Water absorption was measured following the DIN EN 13755 in 65 mm length cubes under atmospheric pressure and under vacuum pressure. Simplifying, the first procedure consists in drying the sample and registering its mass and then placing it under water and waiting 48 hours until the sample is completely wet, measuring the mass. The second procedure consists in evacuating the dry sample for 24 hours, registering its mass and then placing it in under water for 48 hours and afterwards registering the mass again. 


\subsection{Expansion Properties: Thermal and hydric expansion}

Thermal expansion was determined in cylindrical samples of $15 \mathrm{~mm}$ diameter and 50 $\mathrm{mm}$ length in three spatial directions $(X, Y, Z)$ in a special device called dilatometer, as described in Strohmeyer (2003). The samples to be measured were placed in the dilatometer which has six linear displacement transducers with an accuracy of $1 \mu \mathrm{m}$ and two resistance thermometers (one of which is inside a dummy) with an accuracy of $1^{\circ} \mathrm{K}$. The samples were subjected to temperature cycles beginning at $20^{\circ}$ up to $90^{\circ}$ $\mathrm{C}$ with a rate of increase of $1^{\circ} \mathrm{C} / \mathrm{min}$, which ensures the thermal equilibration of the sample (Weiss et al, 2004). The thermal dilatation coefficient $\alpha$ is a measure of how much the length of a sample varies with a change in temperature. The following formula allows its calculation:

$$
\alpha=\Delta \mathrm{l} /\left(\mathrm{I}^{*} \Delta \mathrm{T}\right)
$$

where $\Delta \mathrm{l}$ is the length change, I the length of the sample at the beginning of the measurement and $\Delta \mathrm{T}$ the temperature change in units of $10^{-6} \mathrm{~K}^{-1}$. Residual strain $\varepsilon$ is the ratio between the change in the length of a sample $\Delta \mathrm{l}$ and its original length for a defined temperature interval in units of $\mathrm{mm} / \mathrm{m}$.

\subsection{Mechanical properties}

The mechanical tests were performed using a Universal Testing Machine Class 1 from the company Walter and Bai. For each test, samples were prepared in order to recognize anisotropies, therefore they were drilled in three orthogonal directions (see Figure 6.1).

The uniaxial compressive strength (UCS) test was performed following the DIN EN 1926 in at least 6 samples, having a diameter and length of $50 \mathrm{~mm}$. The method consists in applying a maximum force up to $1000 \mathrm{kN}$ whith a load increase of 1000 $\mathrm{Ns}^{-1}$ perpendicular to the sample faces (which are plan-parallel polished until \pm 0.1 $\mathrm{mm}$ accuracy). The UCS (oucs) is calculated by using this equation: 


$$
\sigma_{\text {ucs }}=\mathrm{F} / \mathrm{A}
$$

where $F$ is the maximum force at which the sample breaks and $A$ is the area in which this force is applied.

Young's modulus (E) is determined in the UCS test and is a measurement of how much a material resists being deformed when a uniaxial force is applied to it. Therefore it relates the strength $(\sigma)$ applied and the strain $(\varepsilon)$ of this material, following this equation:

$$
E=d \sigma_{u c s} / d \varepsilon
$$

For the measurement of the tensile strength the norm DIN 22024 was followed. A maximum force of $50 \mathrm{kN}$ is applied with a load increase of $30 \mathrm{Ns}^{-1}$ onto cylinders of $40 \mathrm{~mm}$ diameter and $20 \mathrm{~mm}$ length, but in order to develop a tensile strength this force is applied perpendicular to their faces. The tensile strength $\left(\sigma_{T}\right)$ is calculated by the following equation:

$$
\sigma_{\mathrm{T}}=2 \mathrm{~F} / \mathrm{d}^{*} \mathrm{I}^{*} \pi
$$

where $\mathrm{F}$ is the maximum force at which the sample is crushed, $\mathrm{d}$ is the diameter and I the height of the sample.

Breaking load at the dowel hole was determined following the DIN EN 13364. Instead of using samples with a $200 \mathrm{~mm}$ edge length and $30 \mathrm{~mm}$ thickness, smaller samples were used (150 mm edge lengths and a thickness of $30 \mathrm{~mm}$ ), which do not have significant difference in the resistance value according to Koch (2005). This method consists in applying a force (up to $50 \mathrm{kN}$ ) at a load increase of $50 \mathrm{Ns}^{-1}$ perpendicular to a dowel fixed in the side of the sample and registering the maximum force at which it breaks down. 


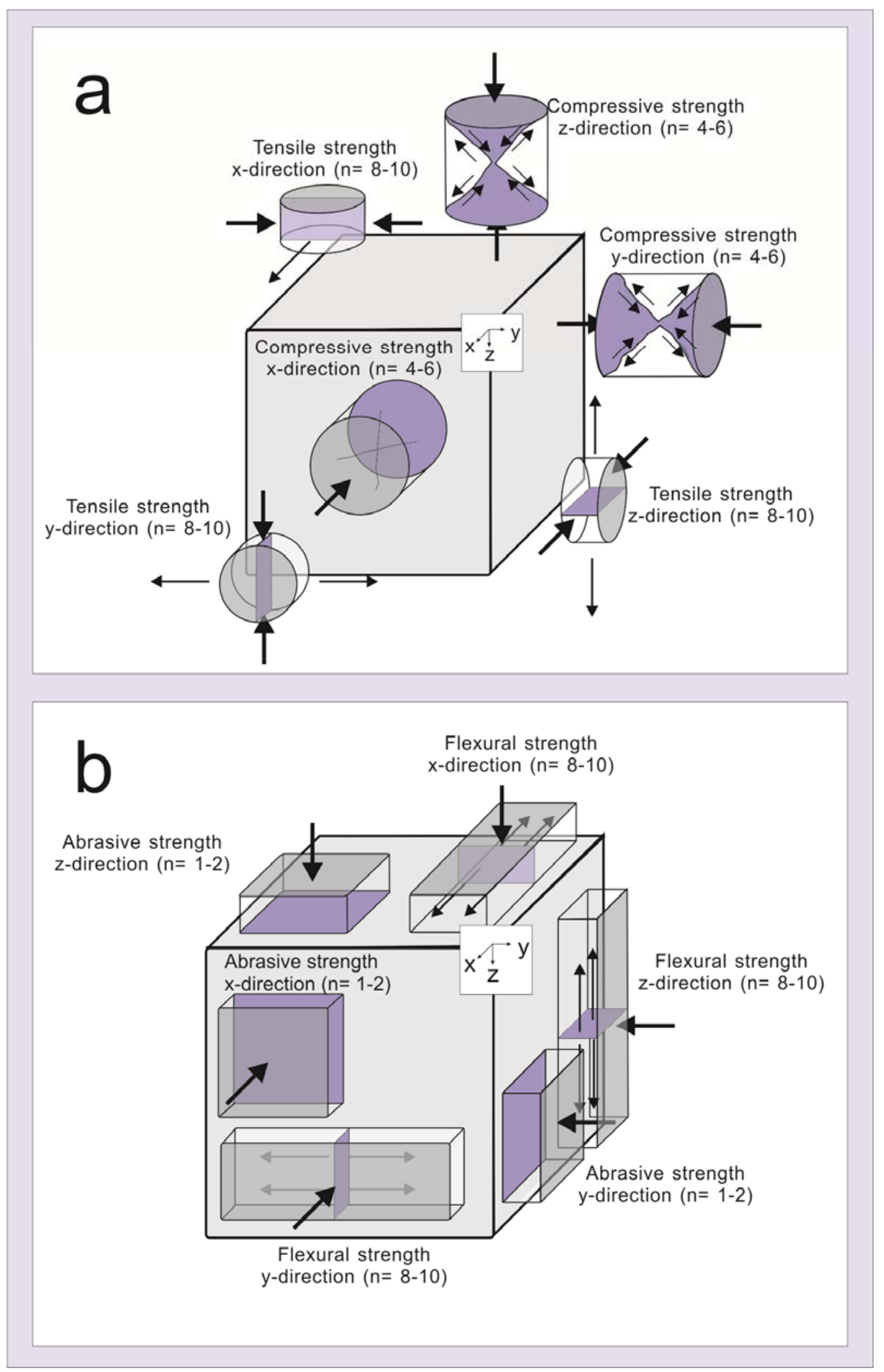

Fig. 6.1: Orientation of the samples in a three-coordinate system for tensile and uniaxial compressive strength (a) and flexural and abrasive strength (b). The thick arrows represent the force applied to the sample and the thin arrows the resulting strain directions in the samples. In light violet color are represented the zones where the strains led to rock failure. Between brackets is the number of samples (n) measured for each direction (modified after Strohmeyer, 2003 and Hoffmann, 2006). 
The flexural strength under concentrated load is determined by the norm DIN EN 12372 in samples with $150 \mathrm{~mm}$ length, $50 \mathrm{~mm}$ width and $25 \mathrm{~mm}$ height. The procedure consists in placing the sample over two supporters with $125 \mathrm{~mm}$ distance between them. In the middle of the sample a maximum linear force of $50 \mathrm{kN}$ is applied with a load increase of $50 \mathrm{Ns}^{-1}$ until the rock failure. The equation used to calculate the flexural strength is the following:

$$
\sigma F=3{ }^{*} F{ }^{*} d / 2{ }^{*} w * h 2
$$

where $\mathrm{F}$ is the maximum force at which the samples breaks down, $\mathrm{d}$ is the distance between the supporters, $w$ is the sample width and $h$ is its height.

Abrasive resistance was performed by the Böhme Method as described in the DIN 52108. A square sample with side lengths of $71 \mathrm{~mm}$ (with a surface area of $50 \mathrm{~cm}^{2}$ ) and a height of $25 \mathrm{~mm}$ is placed in a grinding path with some pressure above it and an abrasive powder underneath it. The grinding path rotates at a speed of $30 \mathrm{rmp}$ and after 22 revolutions it stops. The sample is then rotated in $90^{\circ}$ and another 22 revolutions are started. After the sample has been rotated four times its weight is measured. This procedure is repeated another four times. The value of the abrasive resistance is expressed in the volume lost per $50 \mathrm{~cm}^{2}$ of sample $\left(\Delta \mathrm{V} / 50 \mathrm{~cm}^{2}\right)$ and is calculated by the following equation:

(9) $\Delta \mathrm{V}_{50 \mathrm{~cm} 2}=\left(\Delta \mathrm{m}^{*} 50\right) /\left(\rho \mathrm{r}^{*} \mathrm{a}_{\mathrm{r}}\right)$

where $\Delta \mathrm{m}$ is the loss in mass, $\rho \mathrm{r}$ is the bulk density and $\mathrm{a}_{\mathrm{r}}$ is the real area of the sample surface.

\subsection{Color Measurements}

Color measurements were performed using a Konica Minolta Chroma Meter CR 300 with a xenon flash-lamp with a measuring spot of $8 \mathrm{~mm}$ in diameter. The results are expressed in $L^{*} a^{*} b^{*}$ as required by the International Commission on Illumination 
| General appendix: Analytical procedures

(CIE: Commission Internationale de l'Eclairage), where $L^{*}$ is the brightness $(0$ is black and 100 is white), $a^{*}$ is the green/red axis (-60 is green and +60 is red) and $b^{*}$ is the blue/yellow axis ( -60 is blue and +60 is yellow).

Organic carbon was determined at the Department of Geobiology of the Geoscience Center of the University of Göttingen (GZG) with a C/S analyzer (CS-800, Eltra $\mathrm{GmbH}$, Neuss). 


\section{References}

Allaby A, Allaby M (1990) The concise Oxford dictionary of earth sciences. Oxford University Press, Oxford

Almeida FFM (1971) Geochronological division of the Precambrian of the South America. Rev Bras Geoc 1(1):13-21

Almeida FFM, Amaral G, Cordani UG, Kawashita K (1973) The Precambrian evolution of the South American cratonic margin, South of Amazonas River. In: Nairn ACM, Kanes WH, Stehli FG (Eds) The Ocean Basins and Margins. Plenum, New York, pp 411-446

Artur AC, Meyer AP, Wernick E (2001) Caracterísiticas tecnológicas de granitos ornamentais: a influência da mineralogia, textura e estrutura da rocha. Dados Comparativos e implicações de utilização. In I Simpósio Brasileiro De Rochas Ornamentais E II Seminário De Rochas Ornamentais Do Nordeste. Salvador, Brazil

Ashurst J, Dimes FG (1998) Conservation of Building and Decorative Stone. Elsevier, Amsterdam

ASTM C119-11 (2011) Standard Terminology Relating to Dimension Stone. DOI: 10.1520/C0119-11

Basei MAS, Siga O Jr, Masquelin H, Harara OMM, Reis Neto JM, Preciozzi F (2000) The Dom Feliciano Belt of Brazil and Uruguay and its Foreland Domain the Rio de la Plata Craton: framework, tectonic evolution and correlation with similar provinces of Southwestern Africa. In: Cordani UG, Milani EJ, Thomaz Filho A, Campos DA (eds) Tectonic evolution of South America, Rio de Janeiro, pp 311-334

Basei MAS, Frimmel HE, Nutman AP, Preciozzi F (2008) West Gondwana amalgamation based on detrital zircon ages from Neoproterozoic Ribeira 
and Dom Feliciano belts of South America and comparison with coeval sequences from SW Africa. In: R. J. Pankhurst, R.A.J. Trouw, B. B. de Brito Neves, M.J. De Wit (Editors): West Gondwana: Pre-Cenozoic Correlations Across the South Atlantic Region. Geological Society, London, Special Publications, 294: 239-256.

Basei MAS, Peel E, Sánchez Bettucci L, Preciozzi F, Nutman AP (2011) The basement of the Punta del Este Terrane (Uruguay): an African Mesoproterozoic fragment at the eastern border of the South American Río de La Plata craton. Int J Earth Sci (Geol Rundsch) 100:289-304 DOI 10.1007/s00531-010-0623-1

Bentz A, Martini HJ (1968) Lehrbuch der Angewandten Geologie, Band 2, 1: Methoden zur Erforschung der Lagerstätten von Erzen, Kohle, Erdöl, Slazen, Industrie-Mineralen und Steinen und Erden. Sttutgart (Enke).

Best MG (2003) Igneous and Metamorphic Petrology: Turin, Blackwell Publishing, $729 \mathrm{p}$.

Boone, G. M. (1969). Origin of clouded red feldspars petrologic contrasts in a granitic porphyry intrusion. American Journal of Science 267, 633-668.

Börner K, Hill D (2010) Große Enzyklopädie der Steine: Die Naturstein-Datenbank. CD-ROM. Abraxas Verlag GmbH

Bossi J (1965) Geología del Uruguay. Universidad de la República, Montevideo

Bossi J, Fernández A, Elizalde G (1965) Predevoniano en el Uruguay. Boletín Facultad de Agronomía. 78: 1-49 Montevideo - Uruguay

Bossi J (1969) Recursos minerales del Uruguay. Colección Nuestra Tierra 10: 1-68 Montevideo 
Bossi J, Navarro R (1982) Los granitos negros (microgabros) eocambriano del Uruguay. In: V Congreso Latinoamericano de Geología, Argentina, Actas. II: pp 23-35

Bossi J, Campal N, Garat I, Piñeyro D, Gomez Rifas C (1989) First Integrated Photogeological Map of the Precambrian Dyke Swarm of Uruguai: Some Geological Inferences. Bol IG-USP Sér Cient 20:57-60

Bossi J, Campal N, Garat I, Piñeiro D, Garat I (1990) Contribución a la geología del haz de filones precámbricos de "Granito negro" en el Uruguay. In: Actas Primer Congreso uruguayo de geología. 89-93

Bossi J, Campal N (1991) Granitos negros filonianos del Uruguay - Resultados de las Investigaciones. Ed Facultad de Agronomía, Montevideo.

Bossi J, Campal N (1992) Magmatismo y tectónica transcurrente durante el Paleozoico Inferior en Uruguay. In: Gutierrez Marco JC, Saavedra J, Rabano I (Eds). Paleozoico Inferior de Iberoamérica. Universidad de Extremadura. España. 345-356

Bossi J, Campal N, Civetta L, Demarchi G, Girardi VAV, Mazzucchelli M, Negrini L, Rivalenti G, Fragoso Cesar ARS, Sinigoi S, Texeira W, Piccirillo EM, Molesini M (1993) Early Proterozoic dike swarms from western Uruguay: geochemistry, Sr-Nd isotopes and petrogenesis. Chemical Geology 106: 263-277

Bossi J, Navarro R (2001) Recursos Minerales del Uruguay; versión digital, 418 pp; ISBN 9974-39 -281-0, Ed. Rojobona, Montevideo

Bossi J, Ferrando L (2001) Carta Geológica del Uruguay a escala 1/500 000, v. 2.0, versión digital. Ed. Cátedra de Geología, Facultad de Agronomía, Montevideo 
Bossi J, Schipilov A (2007) Rocas ígneas básicas del Uruguay. Facultad de Agronomía, Montevideo, 364 pp

Brito Neves BB, Cordani U (1991) Tectonic evolution of South America during the Late Proterozoic. Precambrian Research. 53: 23-40

Bucher K, Frey M (2002) Petrogenesis of metamorphic rocks. 7th ed, New York, SpringerVerlag

Büdel J (1957): Die "Doppelten Einebnungsflächen" in den feuchten Tropen. Zeitschrift für Geomorphologie NF 1:201-228

Canavan F (1973) Notes on the terms 'stratiform', 'stratabound' and 'stratigraphic control' as applied to mineral deposits, Journal of the Geological Society of Australia, 19:4, 543-546

Card N (2010) Colour, cups and tiles - Recent discoveries at the Ness of Brodgar. Past -The Newsletter of the prehistoric society. N. 66. London

Caruso LG (1987) Rocas de Aplicación, Proyecto URU/86-002 Reactivación de la Economía y Promoción de Inversiones

Castro de Lima, JJ and Paraguassú, AB (2004) Linear thermal expansion in granitic rocks: influence of apparent porosity, grain size and quartz content. Bull Eng Geol Environ 63:215-220

Centre for Development of Stones - Jaipur, (2011) http://www.cdosindia.com/CDOS/Production.html

Comunità Economica Europea-Uruguay. Piedras Ornamentales del Uruguay. La Cartotecnica, Rovereto. No date 
References

Coronel N, Risso A, Cestau L, Spoturno J, Gómez C, Heizen W, Mati C, Roth W, Theune C, Stampe W (1987) Memoria de la carta de materias primas minerales no metálicas - a escala 1/1.000.000. DI.NA.MI.GE.

Coronel N, Spoturno J, Gómez C, Heinzen W, Mari C, Roth W, Theune C, Stampe W (1987) Carta de los recursos Minerales no matalíferos del Uruguay. DINAMIGE. Montevideo. Uruguay.

De La Roche H, Leterrier J, Grandclaude P, Marchal M (1980) A classification of volcanic and plutonic rocks using R1R2-diagram and major element analyses-its relationships with current nomenclature. Chem Geol 29:183210

DINAMIGE (Dirección Nacional de Minería y Geología) - C.E.R.A.M. (Centro de Estadísticas y Recaudación de la Actividad Minera) (2008) Estadísticas de producción parcial 2007

DINAMIGE (Dirección Nacional de Mineríaa y Geología) (2012) Last access March 2012 http://www.dinamige.gub.uy

DIN 22024 (1989): Rohstoffuntersuchung im Steinkohlebergbau - Bestimmung der Spaltzugfestigkeit von Festgestein. - Beuth Verlag, Berlin.

DIN 52104 (2004): Prüfung von Gesteinskörnungen - Untersuchung zur Beurteilung der Verwitterungsbeständigkeit. - Beuth Verlag, Berlin.

DIN 52108 (1988): Prüfung anorganischer nichtmetallischer Werkstoffe; Verschleißprüfung mit der Schleifscheibe nach Böhme. - Beuth Verlag, Berlin.

DIN EN 12326-1 (2004) and -2 (2000): Schiefer und andere Natursteinprodukte für überlappende Dachdeckungen und Außenwandbekleidungen. Teil 1: 
Produktspezifikation; and Teil 2: Prüfverfahren. Berlin (DIN Deutsches Institut für Normung e.V., Beuth).

DIN EN 12372 (1999): Prüfverfahren für Naturstein - Bestimmung der Biegefestigkeit unter Mittellinienlast. - Beuth Verlag, Berlin.

DIN EN 12407 (2007) Prüfverfahren für Naturstein - Petrographische Prüfung. Beuth Verlag, Berlin.

DIN EN 12440 (2000) Naturstein - Kriterien für die Bezeichnung. Beuth Verlag, Berlin.

DIN EN 12670 (2002): Naturstein - Terminologie. - Beuth Verlag, Berlin.

DIN EN 13364 (2001): Prüfung von Naturstein - Bestimmung der Ausbruchlast am Ankerdornloch. - Beuth Verlag, Berlin.

DIN EN 13775 (2001): Prüfverfahren für Naturstein - Bestimmung der Wasseraufnahme bei atmosphärischem Druck. - Beuth Verlag, Berlin.

DIN EN 1926 (1999): Prüfverfahren für Naturstein - Bestimmung der Druckfestigkeit. - Beuth Verlag, Berlin.

Direcção Geral de Energia e Geologia (DGEG), Divisão de Estatística (2011) http://www.dgge.pt/

Federación Española de la Piedra Natural (2008) Informe anual Sector de la Piedra Natural 2007 http://www.fdp.es/wp-content/uploads/2010/12/Informe-sector2007.pdf

Fei Y (1995) Thermal expansion. In Ahrens T 1995 Mineral physics crystallographic: A handbook of physical constants 
Ferrando L, Fernandez A (1971) Esquema tectónico—cronoestatigráfico del predevoniano en Uruguay. In: XXV Congreso Brasilero de Geología, vol 1. San Pablo, Paulo, pp 199-210

Fischer C, Kaufhold S, Wedekind W, Dohrmann R, Karius V, Siegesmund S Weathering of Fruchtschiefer building stones: mineral dissolution or rock disaggregation? (2011) Environ Earth Sci 63:1665-1676 DOI 10.1007/s12665-011-0986-z

Fluhr JW, Gloor M, Merkel W, Warnecke J, Höffler U, Lehmacher W, Glutsch J. (1998) Antibacterial and sebosuppressive efficacy of a combination of chloramphenicol and pale sulfonated shale oil. Multicentre, randomized, vehicle-controlled, double-blind study on 91 acne patients with acne papulopustulosa (Plewig and Kligman's grade II-III). Arzneimittelforschung. 48(2):188-96.

Fragoso César R (1980) O cratón do Río de la Plata e o Cinturão Dom Feliciano no Escudo Uruguaio-Sul-Riograndense. XXXI Congresso Brasileiro de Geología; Anais, 5: 1879-2892. Brasil

García-Guinea J, Lombardero M, Roberts, B, Taboada J, Peto A (1998) Mineralogy and microstructure of roofing slate: thermo-optical behaviour and fissility. Materiales de construcción, Vol. 48, $n^{\circ} 251$

Gayko G, Cholcha W, Kietzmann M. (2000) Anti-inflammatory, antibacterial and antimycotic effects of dark sulfonated shale oil (ichthammol). Berl Munch Tierarztl Wochenschr. 113(10):368-73

Gómez-Heras M, Smith BJ, Fort R (2006) Surface temperature differences between minerals in crystalline rocks: Implications for granular disaggregation of granites through thermal fatigue. Geomorphology 78:236-249 
Halls HC, Campal N, Davis DW, Bossi J (2001) Magnetic studies and U-Pb geochronology of the Uruguayan dike swarm, Uruguay: paleomagnetic and economic implications. J South Am Earth Sci 14 (2001):349-361

Hartmann LA, Campal N, Santos O, Macnaugton N, Schipilov A, Lafon J (2001) Archean crust in the Río de la Plata Craton, Uruguay: SHRIMP U-Pb zircon reconnaissance geochronology. Journal of South American Earth Sciences. Vol 14: 557-570

Heldal T, Kjølle I, Meyer GB, Dahlgren S (2008) National treasure of global significance. Dimension-stone deposits in larvikite, Oslo igneous province, Norway. In Slagstad, T. (ed.) Geology for Society, Geological Survey of Norway Special Publication, 11, pp. 5-18.

Hirschwald J (1912) Die Prüfung der natürlichen Bausteine auf ihre Verwitterungsbeständigkeit. Verlag W Ernst and Sohn, Berlin

Hoffmann A (2006) Naturwerksteine Thailands: Lagerstättenerkundung und Bewertung. Dissertation, University of Göttingen

Hoffmann A, Siegesmund S (2007) The dimension stone potential of Thailand overview and granite site investigations In: Prikryl R and Smith BJ (eds) Building Stone Decay: From Diagnosis to Conservation. Geological Society, London, Special Publications, 271, 43-54. The Geological Society of London

Illiev IG (1967) An attempt to estimate the degree of weathering of intrusive rocks from their physica-mechanical properties. Proc 1st Int Congress Int Soc Rock Mech, Lisbon 1:109-114.

Jackson JA (1997) Glossary of Geology (4th edition). American Geophysical Institute, Alexandria, Virginia 
Jorge Quiroz C Consultores Asociados (2006) Estudio de Mercado y Competitividad de las Industrias de Rocas Ornamentales, Informe Final http://www.jcih.cl/documentacion/estudios/Estudios\%20de\%20Mercado\%20y\%20 Competitividad\%20Rocas\%20Ornamentales.pdf

Klopfer H (1985) Feuchte. In: Lutz P, Jenisch R, Klopefer H (Eds.) Lehrbuch der Bauphysik. Teubner Verlag, Stuttgart.

Koch A (2005) Deformation von Fassadenplatten aus Marmor: Schadenskartierungen und gesteinstechnische Untersuchungen zur Verwitterungsdynamik von Marmorfassaden. Dissertation, University of Göttingen

Koch A, Siegesmund S (2004) The combined effect of moisture and temperature on the anomalous behavior of marbles. Environ Geol 46/3-4:350-363.

Köhler W (1991) Untersuchungen zu Verwitterungsvorgängen an Carrara-Marmor in Potsdam-Sanssouci. Berichte zu Forschung und Praxis der Denkmalpflege in Deutschland. Steinschäden-Steinkonservierung 2:50-53.

Kretz R (1983) Symbols for rock-forming minerals. American Mineralogist, Volume 68: $277-279$

Laboratório Nacional de Energia e Geologia, Portugal. Last access March 2012 http://e-geo.ineti.pt/bds/ornabase/

Le Maitre RW, Streckeisen A, Zanettin B, Le Bas MJ, Bonin B, Bateman P, Bellieni G, Dudek A, Efremova S, Keller J, Lameyre J, Sabine PA, Schmid R, Sørensen H, Woolley AR (2002) Igneous Rocks A Classification and Glossary of Terms. Recommendations of the International Union of Geological Sciences Subcommission on the Systematics of Igneous Rocks. Cambridge University Press 
Listemann H, Schölermann A, Meigel W. (1993) Antifungal activity of sulfonated shale oils. Arzneimittelforschung. 43(7):784-8.

Mazuchelli M, Rivalenti G, Piccirillo EM, Girardi VAV, Civetta L, Petrini R (1995) Petrology of the Proterozoic mafic dyke swarms of Uruguay and constraints on their mantle source composition. Precambrian Research 74 (1995) 177194

Medina E, Carrión R (1986) Inventario de las Explotaciones de Granito Negro de la República Oriental del Uruguay. DINAMIGE, Montevideo

Medina E, Carrión R (1987) Reconocimiento de los Filones de Granito Negro denunciados en Departamento de Florida. DINAMIGE, Montevideo

Middlemost E (1997) Magmas, Rocks and Planetary Development. A Survey of Magma/lgneous Rock Systems Geological Magazine (1998), 135: 143-158

Midot D (1984) Etude géologique et diagnostique métallogénique pour I' exploration du secteur Minas (Uruguay); Tesis, 3eme Cycle, Univ. P. et M. Curie. París. France. pp. 1-175.

Montani C (2008) Stone. Repertorio economico mondiale World marketing handbook Faenza Editrice ISBN 978-88-8138-121

Morales Demarco M, Jahns E, Rüdrich J, Oyhantçabal P and Siegesmund S (2007) The impact of partial water saturation on rock strength: an experimental study on sandstone. Z. dt. Ges. Geowiss., 158: 869-882, Stuttgart

Morales Demarco M, Oyhantçabal P, Stein KJ, Siegesmund S (2011) Black dimensional stones: geology, technical properties and deposit characterization of the dolerites from Uruguay. Environmental Earth Sciences Volume 63, Numbers 7-8, 1879-1909, DOI: 10.1007/s12665-0100827-5 "Special Issue: Monuments under Threat: Environmental Impact, Preservation Strategies and Natural Stone Resources" 
Morales Pérez E (2004) Rocas Ornamentales del Uruguay. Trabajo Final del Curso "Recursos Minerales" Universidad de la República, Montevideo

Morales Pérez E, Muzio R (2005) Balanço mineral dos granitos ornamentais do Uruguai periodo 1990 - 2003. I International Congress on Dimensional Stones and II Simpósio Brasileiro de Rochas Ornamentais, Guarapari, Brazil

Mosch S (2008) Optimierung der Exploration, Gewinnung und Materialcharakterisierung von Naturwerksteinen. Dissertation, University of Göttingen

Mosch S and Siegesmund S (2007) Statischer Verhalten petrophysikalischer und technischer Eigenschaften von Naturwerksteinen. Z. dt. Ges. Geowiss., $158 / 4$, S. $821-868$

Mosch S, López de Luchi MG, Siegesmund S (2007) Dimensional stones in Argentina. Z. dt. Ges. Geowiss., 158/3, p. 447-469

Mosch S, Nikolayew D, Ewiak O and Siegesmund S (2011) Optimized extraction of dimension stone blocks. Environmental Earth Sciences Volume 63, Numbers 7-8, 1911-1924, DOI: 10.1007/s12665-010-0825-7 "Special Issue: Monuments under Threat: Environmental Impact, Preservation Strategies and Natural Stone Resources"

Mosch S, Siegesmund S (2007) Statistische Bewertung gesteintechnischer Kenndaten von Natursteinen. Z dtsch Ges Geowiss 158/4:821-868.

Motoki A, Zucco LL (2005): Digital color specification for ornamental rocks using image scanner: its technical challenge, on-going development, further innovation, and application. I Congresso Internacional de Rochas 
Ornamentais and II Simpósio Brasileiro de Rochas Ornamentais. CD-ROM. Guarapari, Brazil.

Muzio R, Artur AC (1999) Petrological features of the Santa Teresa Granitic Complex Southeastern Uruguay. Journal of South American Earth Sciences 12(5): $501-510$

Nakano S, Akai J, Sugaki A (2002) Fluorite particles inducing butterfly aggregates of incipient microperthite in alkali feldspar from a syenite, the Patagonian Andes, southern Chile. American Mineralogist 87, 1377-1383.

Natursteinwerk Theuma AG. Last access March 2012 http://www.natursteinwerktheuma.de

Nikolayev D, Siegesmund S, Mosch S and Hoffmann A (2007) Model-based prediction of unfractured rock masses. Zeitschrift der Deutschen Gesellschaft für Geowissenschaften, 158 (3): 483-490

Oyhantçabal P (2005) The Sierra Ballena Shear zone: kinematics, timing and its significance for the geotectonic evolution of southeast Uruguay. Dissertation, University of Göttingen

Oyhantçabal P Siegesmund S, Wemmer K Presnyakov S and Layer P (2009) Geochronological constraints on the evolution of the southern Dom Feliciano Belt (Uruguay) Journal of the Geological Society, London, Vol. 166:1075-1084. DOI: 10.1144/0016-76492008-122

Oyhantçabal P, Derregibus MT, Muzio R (1990a) Contribución al conocimiento petrográfico, geoquímico y estructural del Granito de La Paz. Resúmenes Ampliados 1: 81-89 Congreso Uruguayo de Geología, Montevideo 
Oyhantçabal P, Medina E, Spoturno J (1990b) Geología y petrología del stock de gabro del Arroyo Mahoma. Resúmenes Ampliados 1:115-121 Congreso Uruguayo de Geología, Montevideo.

Oyhantçabal P, Muzio R, Derregibus MT, Nardi LVS (1998) The Soca intrusion: a rapakivi granite of Uruguay. Journal of South American Earth Sciences, 11(2):169-178

Oyhantçabal P, Siegesmund S, Stein KJ, Spoturno J (2007) Dimensional stones in Uruguay: situation and perspectives Z. dt. Ges. Geowiss. 158(3): 417-428.

Oyhantçabal P, Siegesmund S, Stein KJ, Spoturno J (2008) Dimensional stones in Uruguay: situation and perspectives Litos 98: 72-96

Oyhantçabal P, Siegesmund S, Wemmer K (2010) The Río de la Plata Craton: a review of units, boundaries, ages and isotopic signature. International Journal of Earth Science, Volume 100(2-3):201-220 DOI: 10.1007/s00531010-0580-8

Oyhantçabal P, Siegesmund S, Wemmer K (2011) The Río de la Plata Craton: a review of units, boundaries, ages and isotopic signature. International Journal of Earth Science, Volume 100, Numbers 2-3, 201-220 DOI: 10.1007/s00531-010-0580-8.

Oyhantçabal P, Spoturno J, Aubet N, Cazaux S, Huelmo S (2003) Proterozoico del Suroeste del Uruguay Nueva propuesta estratigráfica para la Formación Montevideo y el Magmatismo Asociado. Revista de la Sociedad Uruguaya de Geología. Publicación especial N 1, II Taller sobre la Estratigrafía del Precámbrico del Uruguay:34-48

Oyhantçabal P, Spoturno J, Goso E, Heimann A, Bergalli L (2001) Asociaciones litológicas en las supracrustales del grupo Lavalleja y sus intrusiones asociadas en la hoja Fuente del Puma (Sur de Minas). III Cong. Uruguayo 
de Geología y XI Cong. Latinoam. Geol. Montevideo, Uruguay. CD Abstract, 246.

Oyhantçabal P, Spoturno J, Loureiro (2007) Caracterización Geológica de las rocas Paleoproterozoicas de la región centro-sur del Uruguay (Terreno Piedra Alta - Cratón del Río de la Plata) Actas V Congreso Uruguayo de Geología. Montevideo

Oyhantçabal P, Siegesmund S, Stein KJ (2006) Perspektiven für schwarze Steine. Naturstein, v. 61, 62-65

Palmstrøm A (1982) The volumetric joint count - a useful and simple measure of the degree of rock jointing. - Abstracts, Proc. 4th Int. Cong. Int. Assoc. Eng. Geol., 5: S. 221-228, New Delhi

Palmstrøm A (1996) The weighted joint density method leads to improved characterization of jointing. Conference on recent advances in tunnelling technology, New Delhi

Palmstrøm A (2001) Measurement and characterization of rock mass jointing, in "InSitu Characterization of rocks", editors: Sharma VM and Saxena KR, A.A. Balkema Publishers, Lise/Abingdon/Exton(PA)/Tokio

Passchier CW, Trouw RAJ (1996) Microtectonics 2nd Edition Springer-Verlag Berlin Heidelberg New York ISBN 3-540-58713-6

Peschel A (1977) Natursteine VEB Deutscher Verlag für Grundstoffindustrie, Leipzig

Plümper O, Putnis A (2009) The Complex Hydrothermal History of Granitic Rocks: Multiple Feldspar Replacement Reactions under Subsolidus Conditions. doi:10.1093/petrology/egp028 
Porada H (1989) Pan-African rifting and orogenesis in Southern to Equatorial Africa and Eastern Brazil. Precambrian Res. 44, 103-136.

Preciozzi F, Masquelin H, Basei MAS (1999) The Namaqua/Grenville Terrane of eastern Uruguay. II South American Symposium on Isotope Geology, Carlos Paz.

Preciozzi F, Spoturno J, Heinzen W, Rossi P (1985) Memoria explicativa de la carta geológica del Uruguay a la escala 1:500.000. DI.NA.MI.GE.

Putnis A, Hinrichs R, Putnis CV, Golla-Schindler U, Collins LG (2007) Hematite in porous red-clouded feldspars: Evidence of large-scale crustal fluid-rock interaction. Lithos 95, 10-18.

Quick GW (2002) Selective guide to the specification of dimension stone. Discovering stone, vol. 1, issue 1 (www.discoveringstone.com).

Reeder RJ and Markgraf SA (1986) High-temperature crystal chemistry of dolomite. American Mineralogist, Volume 71, 795-804

Robertson S (1999) BGS Rock Classification Scheme, Volume 2, Classification of metamorphic rocks. British Geological Survey Research Reports, Research Report 99-02

Robie RA, Bethke PM (1966) X-ray crystallographic data, molar volumes and densities of minerals. Clark Jr SP (Ed.) Handbook of Physical Constants. Geol. Soc. Am, pp. 58-73

Rohowski H (2001) Druckfestigkeit und Ausbruchlast neu geregelt. Naturstein 3:8892

Rüdrich J (2003) Gefügekontrollierte Verwitterung natürlicher und konservierter Marmore. Dissertation, University of Göttingen 
Rüdrich J, Kirchner D, Siegesmund S (2010) Physical weathering of building stones induced by freeze-thaw action: a laboratory long-term study. Environ Earth Sci. DOI 10.1007/s12665-010-0826-6

Ruiz García C (1977) Aplicaciones al microscopio en relación con la calidad de las pizarras de techar. Boletín Geológico y Minero. T. LXXXVIII-I (72-77)

Sánchez Bettucci L (1998) Evolución tectónica del Cinturón Dom Feliciano en la región Minas-Piriápolis, Uruguay. PhD Tesis, Facultad de Ciencias Exactas y Naturales, Universidad de Buenos Aires, pp. 1-344

Sánchez Bettucci L, Ramos VA (1999) Aspectos geológicos de las rocas metavolcánicas y metasedimentarias del Grupo Lavalleja, sudeste de Uruguay. Revista Brasileira de Geociências, 29, 557-570

Scheer K (1964) Estudio sobre la Industria del Granito y del Mármol en el Uruguay. BGP Bergbau-Planung $\mathrm{GmbH}$, Essen

Shelley D (1993) Igneous and metamorphic rocks under the microscope. Chapman and Hall, London

Siegesmund S and Dürrast H (2011) Physical and mechanical properties of rocks. In Stone in architecture: Properties, Durability, 4th edition, editors: Siegesmund S and Snethlage R, Springer-Verlag Berlin Heidelberg

Siegesmund S, Dahms M (1994) Fabric-controlled anisotropy of elastic, magnetic and thermal properties. In: Bunge HJ, Siegesmund S, Skrotzki W, et al (eds) Textures of Geological Materials. DGM Informationsgesellschaft, Oberursel. 
Siegesmund S, Dürrast H (2011) Physical and mechanical properties of rocks, in Stone in architecture: properties, durability. 4th edition. Springer. 552 p., editors: Siegesmund S and Snethlage R

Siegesmund S, Mosch S, Scheffzük Ch, et al (2008) The bowing potential of granitic rocks: rock fabrics, thermal properties and residual strain. Environ Geol 55:1437-1448.

Siegesmund S, Nikolayev D, Hoffmann A, Mosch S (2007a) 3D-Block-Expert. Naturstein 5: 102-107

Siegesmund S, Nikolayev D, Mosch S, Hoffmann A (2007b) Modell-based prediction of unfractured rock masses. Z. dt. Ges. Geowiss. 158(3): 483-490, Stuttgart

Singewald C (1992) Naturstein - Exploration und Gewinnung. 260 S., Köln, Bad Bentheim (Rudolf Müller)

Slates

Sousa LMO (2010) Evaluation of joints in granitic outcrops for dimension stone exploitation. Quarterly Journal of Engineering Geology and Hydrogeology, v.43: 85-94 doi: 10.1144/1470-9236/08-076

Spoturno J, Oyhantçabal P, Aubet N, Cazaux S (2004a) Mapa geológico y de recursos minerals del departamento de San José a escala 1/100.000, Memoria Explicativa, Capítulo II Geología. Proyecto CONICYT 6019

Spoturno J, Oyhantçabal P, Aubet N, Cazaux S (2004b) Mapa geológico y de recursos minerals del departamento de Canelones a escala 1/100.000, Memoria Explicativa, Capítulo II Geología. Proyecto CONICYT 6019

Spoturno J, Oyhantçabal P, Aubet N, Cazaux S (2004c) Mapa geológico y de recursos minerals del departamento de Montevideo a escala 1/100.000, Memoria Explicativa, Capítulo II Geología. Proyecto CONICYT 6019 
Steiger M, Charola AE, Sterflinger K (2011) Weathering and deterioration, in Stone in architecture: properties, durability. 4th edition. Springer. 552 p., editors: Siegesmund S and Snethlage R

Streckeisen A (1976) To each plutonic rock its proper name Earth-Sci. Rev. 12: 1-33.

Strohmeyer D (2003) Gefügeabhängigkeit technischer Gesteinseigenschaften. Dissertation, University of Göttingen

Sveriges geologiska undersöknig (Swedish Geological Survey) (2009): Statistics of the Swedish Mining Industry http://www.sgu.se/sgu/sv/produktertjanster/produkter/sgu_publ/publ_beskr/perpubl_2009-1.html Accesed 7 August 2010

Techera J, Arriguetti R, Spoturno J (2004a) Mapa geológico y de recursos minerals del departamento de San José a escala 1/100.000, Memoria Explicativa, Parte III Recursos minerales. Proyecto CONICYT 6019

Techera J, Arriguetti R, Spoturno J (2004b) Mapa geológico y de recursos minerals del departamento de Canelones a escala 1/100.000, Memoria Explicativa, Parte III Recursos minerales. Proyecto CONICYT 6019

Techera J, Arriguetti R, Spoturno J (2004c) Mapa geológico y de recursos minerals del departamento de Montevideo a escala 1/100.000, Memoria Explicativa, Parte III Recursos minerales. Proyecto CONICYT 6019

Teixeira W, Renne PR, Bossi J, Campal N, D’Agrella Filho MS (1999) 40Ar-39Ar and $\mathrm{Rb}-\mathrm{Sr}$ geochronology of the Uruguayan dike swarm, Río de la Plata Craton and implications for Proterozoic intraplate activity in western Gondwana. Precambrian Research 93:153-180 
Twidale CR (2002) The two-stage concept of landform and landscape development involving etching: origin, development and implications of an idea EarthScience Reviews 57: 37-74

United Nations (2010) Framework Classification for Fossil Energy and Mineral Reserves and Resources 2009. Economic Commission for Europe, Committee on Sustainable Energy

Vázquez P, Siegesmund S, Alonso FJ (2011) Bowing of dimensional granitic stones Environm Earth Scien 63:1603-1612

Wagner W (2007) Grundlagen für die Prüfung von Dach- und Wandschiefern. Z. dt. Ges. Geowiss., 158/4, S. 785-805

Ward CR, Gómez Fernández F (2003) Quantitative mineralogical analysis of Spanish roofing slates using the Rietveld method and X-ray powder diffraction data. Eur. J. Mineral., Vol. 15, nº 6, pp. 1051-1062

Weiss G (1992) Die Eis- und Salzkristallisation im Porenraum von Sandsteinen und ihre Auswirkungen auf das Gefüge unter besonderer Berücksichtigung gesteinsspezifischer Parameter. Münchner Geowiss Abh B 9, Verlag Dr. Friedrich Pfeil, Munich.

Weiss T, Siegesmund S, Kirchner D, Sippel J (2004) Insolation weathering and hygric dilatation: two competitive factors in stone degradation. Environ Geol 46:402-413

World Bank (2010) http://www.worldbank.org/ Accesed 7 August 2010 


\section{Acknowledgments}

During these years that took me carry out and finish my PhD I was blessed by the help of many different persons, from other countries, with other languages, histories and cultures. I would like to thank them all, for sharing some of their life-time with me and inspiring me in so many ways. To do this, I will try to keep a chronological order, to not forget anyone. I am really sorry if I do forget to write your name here, I meant to thank you too.

In my home country, Uruguay, I would like to thank my professors, who teach me not just geology, but the wonder of the mineral part of the earth. I thank Jorge Spoturno, among other things, for asking me on one winter afternoon in the corridors of the faculty in Montevideo, if I was interested in helping a German student in his fieldwork. I would also like to thank Pedro Oyhantçabal, my co-referent, for the confidence that he placed in me, for his support, for his wise generosity in showing his geological and vital knowledge, for his unwavering optimism and scientific accuracy.

I give my thanks to Juan Ledesma, for encouraging me to doubt about everything in the field of mineral resources and doing so to really learn the complexities of this subject. I would like to thank Leda Sánchez Bettucci for joining me to the field and helping me to take samples of the hard dolerites. To Claudio Gaucher, Gerardo Veroslavsky, Jorge Bossi and Haroldo Albanell I extend my thanks for helping me by sharing their experience and geological wisdom.

I thank also all the Uruguayan mining companies and people related to this industry that help me achiev my goal: Giovanni, Giusseppe and Carmine Rufo, Silvana Martinez, Black Stone S.A., Pimafox S.A., Comercio Exterior S.A., Vodelín S.A., Piedrahita and Froche families.

I would also like to thank my many friends and colleges in the faculty in Montevideo that offered me their time by joining me to field campaigns and helping me processing and carrying more than two tons of dimensional stones: Natalia Seluchi, Rodrigo Novo, Alejandro Mlynarski, Lucía Samaniego, Guillermo "Topo" García; and to my amassing class colleges, some of them my dearest friends: Federico Chernuschi, Bruno Conti, Federico González, Leticia González, Josefina Marmisolle, Agustín Soto, Mariano Cáceres, Rafael Sanz, Gregorio González, Gonzalo "Geógrafo" and Eduardo Castiglioni; and also other colleges and friends in the faculty, who made my days brighter: Cecilia Pérez, Carolina López, Héctor, Joaquín "Jeta" Cabrera, Leticia Chiglino, Santiago Stareczeck, Ximena Blanco, Gonzálo 
Sánchez, Viviana Gianotti, Hernan Barcelona, Alejandra Pascale, Matías Soto, Valeria Mesa, Anibal Furtado, Ángeles Beri, Richard Fariña, Pablo Lara, and all the people that show me the world through their own eyes.

To Alex Wetzel I give me special thanks, because he had the courageous idea of making his geological mapping in Uruguay, making me cross my life-path with Siggi and Klaus. I also thank him for his friendship and hospitality in Göttingen, which made me love this city and open my academic and existential possibilities. To all his friends, which became also mine: Lotte, Marlene, Roman, Nils, Diego, Sarah, Tobi, Lena, Wiebke, Michael, Marion; thank you all for making my first time in Germany a real pleasure.

I would never end to thank Siegfried "Siggi" Siegesmund, my referent, for believing in me the first time when he gave me the opportunity to came to Germany to do a practical work, the second time when he offered me to make this $\mathrm{PhD}$ with him, and the innumerable times when I stumbled and he help me stand up. I thank him also for his patience, his guide, his amazing excursions, and his humor. I thank also one thing that he had in common with Klaus: his love to Uruguay and our good "asados" (barbecues), wines and tomatoes, which make our field work in Uruguay unforgettable. To Brigitte and Mara go also my thanks, for the lovely evening in their garden and the exquisite "Johanissbeerkuchen" recipe.

To Klaus Wemmer go also my special thanks, for being such a good friend, without whom I wouldn't had the strength to carry all my stones by myself and would had given up in the hopeless moments. In his always-open-office we share meaningful conversations, which enlightened me and made me look ahead with a smile and a new strength.

To my colleagues in the department, who showed me the way in our Teklab and Institute and gave some of their precious time just to help me: Stephan Mosch, Heidrun Stück, Malte Drobe, Christiane Schneider, Frithjof Bense, Stefan Löbens, Victoria Shushakova, Birte Graue, Wanja Wedekind, Günter Tondock, Chrisitian Knell, Marc Wengler, Felix "Elmo" Hüttenrauch, Oktawian "Oki" Ewiak, Carl Santelmann. Too late I thank Jörg Rüdrich, who teach me how to be precise and careful in the lab with his kind and easy-going way of be, it was an honor for me working with him.

I thank Karl-Jochen Stein, for the many conversations that we had respect to the dimensional stones, sharing with me his many years of experience in the subject. For helping me in new measurments and procedures I would like to help Rudolf Naumann, Axel Vollbrecht, 
Wolfgang Wagner, Dieter Jung, Harald Tonn, Peter Machner, Matthias Gehrke, Michael Huppert, Cornelius Fischer.

To the other part of our working group I would like also to thank: Ana Luque, Patricia Vázquez, Silvia Cardona and Estefanny Dávalos, for their eternal smile, the teaching of the macros in excel, the Mexican guacamole recipe between many other unforgettable things. To Törok Ákos, Bálazs Kiss, Miguel Basei and Ivonní, Dimitry Nikolayew go also my thanks.

To Eberhard Jahns and all the staff in Gesteinslabor: Hansjörg, Gerd and Marco, for guiding me in my first steps in the world of rock mechanics and making me feel at home in Heiligenstadt.

With my family I will be always grateful, for always being there, so warm and loving, for giving me the true tolls for living: love, respect, optimism, faith, perseverance, respect, tolerance and humility. I thank specially my mum, Mariella Demarco Berois, for this life that she gave me and the amazing job of teaching me how to love it, without her all this would had never happened.

I thank also my beloved sisters: Marti and Juli, for teaching me so many things and also learning some from me, they are like a gift of the life; true companions in this adventure. I also would like to thank their husbands, Santi and Omar, for being like my brothers. I thank also my friends in Uruguay for allways being there for me: Ro and family, Cecilia "Checha" Goblin, Patricia Abete, Martina Gadea, Noel and family, Juancito, Rafa de León and family, Doris Obrer and family, "Qk", Marcia Viglioni, Pata Torres, Analia West, "Gaucho" Vázquez, Rosamaría Tiscordio, Anahí, Pablo Trindade, Sebastián Niz, Lo Opertti, Isabel and Beto, Nibia and family, Diego Cabral, Anni Wohltmann, Maiso, Juan Odriozola, Bico, Andrea Danler, Jacinto Casaravilla, and also La Vela Puerca, for being my soul soundtrack.

I thank all my friends in Germany for their friendship: to my home mates Frida, Christoph, Tobi, Nils and Iza, for being my new family in my second home, to Marike and Sarah for being so warm, funny and sincere; to Rogue Steady Orchestra and Earl Mobilé Orchestra for playing so good. I would like to thank my love, Moritz, for giving me the best birthday present ever when he shared with me his beautiful soul.

I am very grateful to DAAD for the long term fellowship that allowed me to start and finish this $\mathrm{PhD}$. 


\section{Curriculum Vitae}

- Date of birth: December 25th, 1981 in Rivera, Uruguay

- Nationality: Uruguayan and Italian

\section{Education}

\section{> Primary School:}

1987-1993 Escuela № 8 República Argentina (Rivera, Uruguay)

\section{$>$ High School:}

1994-2000: Bachillerato Agronomía (High School Degree - A level in Agronomy related subjects) Liceo No 1 Dra. Celia Pomoli (Rivera, Uruguay)

\section{$>$ University:}

2000-2007: Diploma in Geology "The impact of partial water saturation in the strength of rocks: an experimental study in sandstone" at the Universidad de la República, Facultad de Ciencias (School of Sciences; Montevideo, Uruguay).

October 2008: Beginning of PhD studies in Georg-August Universität Göttingen with a DAAD fellowship (Göttingen, Germany).

\section{Working Experience}

> Montevideo, Uruguay, 2005: Internship at OEA in the Environmental Protection and Sustainable Development of the Guaraní Aquifer System Project.

$>$ Heiligenstadt, Germany, 2006: Internship at Gesteinslabor.

> Göttingen, Germany, 2006: Geology assistant at Georg-August-Universität.

> Montevideo, Uruguay, 2007-2008: Geology consultant at Consorcio Guaraní

\section{Publications}

> Morales Demarco M, Jahns E, Rüdrich J, Oyhantcabal P and Siegesmund S (2007) "The impact of partial water saturation in rock strength: an experimental study on sandstone.” In „Zeitschrift der Deutschen Gesellschaft für Geowissenschaften (ZDGG)” 158(4), 869-882

> Morales Demarco M, Oyhantcabal P, Stein KJ and Siegesmund S (2011) "Black dimensional stones: geology, technical properties and deposit characterization of the dolerites from Uruguay." In Special Issue Environmental Earth Sciences, 63(7-8), 1879-1909, DOI: 10.1007/s12665-010-0827-5

> Morales Demarco M, Oyhantçabal P, Stein K-J and Siegesmund S: "Dolomitic slates from Uruguay: petrophysical and petromechanical characterization and deposit evaluation" (in revision).

Morales Demarco M, Oyhantçabal P, Stein K-J and Siegesmund S: "Granitic dimensional stones in Uruguay: evaluation and assessment of potential resources" (in review). 